$\frac{2}{1}, 209580$

\title{
Work Plan for Conducting an Ecological Risk Asses̀ment at J-Field, Aberdeen Proving Ground, Maryland
}

Environmental Assessment Division Argonne National Laboratory

Operated by-The University of Chicago; under Contract W-31-109-Eng-38, for the

United States Department of Energy 


\section{Argonne National Láboratory}

Argonne National Laboratory, with facilities in the states of Illinois and Idaho, is owned by the United Ștates Government, and operated by the University of Chicago under the provisions of a contract with the Department of Energy.

This technical memo is a product of Argonne's Environmental Assessment Division (EAD). For information on the division's scientific and engineering activities, contact:

Director, Environmental Assessment-Division

Argonne National Labóratory

Argonne, Illinois 60439-4815 Télephone (708) 252-3107

Presented in this technical memo are preliminary results of ongoing work or work that is more limited in scope and depth than that described in formal reports issued by the 'EAD.

Publishing support services were provided by Argonne's Information and Publishing Division.

\section{Disclaimer}

This report was prepared as an account of work sponsored by an agency of the United Statés Govemment. Neither the United States Government nor any agency thereof, nor any of their employees, makes ariy warranty, express or implied, or assumes any legal liability or responsibility for the accuracy, completeness, or usefulness of any information, apparatus, product, or process disclosed, or represents that its use would not infringe privately owned rights. Reference herein to any specific commercial product, process, or senvice by trade name, trademark, manufacturer, or otherwise, does not necessarily constitute or imply its endorsement, recommendation, or favoring by the United States. Government or any agency thereof. The views and opinions of authors expressed herein do not necessarily state or reflect those of the United States Govemment or any agency thereof.

Reproduced directly from the best available copy.

Available to DOE and DOE contractors from the Office of Scientific and Technical Information, P.O. Box 62, Oak Ridge, TN 37831; prices available from (615) 576-8401.

1 Available to the public from the National Technical Information Senvice, U.S. Department of Commerce, 5285 Port Royal Road, Springfield, VA 22161. 


\section{DISCLAIMER}

Portions of this document may be illegible in electronic image products. Images are produced from the best available original document. 


\section{Work Plan for Conducting an Ecological Risk Assessment at J-Field, Aberdeen Proving Ground, Maryland}

by I. Hlohowskyj, J. Hayse, R. Kuperman, R. Van Lonkhuyzen, E. Stull, C. Dunn, C. Yuen, T. Patton, L. Martino, P. Benioff, and R. Biang

Environmental Assessment Division,

Argonne National Laboratory, 9700 South Cass Avenue, Argonne, llinois 60439

March 1995

Work sponsored by U.S. Army, Aberdeen Proving Ground, Directorate of Safety, Health, and Environment

DITRIBUTION OF THIS DOCUMENT IS UNLMIRED

Ther

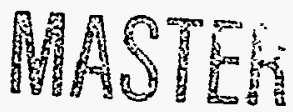


This report is printed on recycled paper. 


\section{CONTENTS}

FOREWORD $\ldots \ldots \ldots \ldots \ldots \ldots \ldots \ldots \ldots \ldots \ldots \ldots \ldots \ldots \ldots \ldots \ldots \ldots \ldots \ldots \ldots$

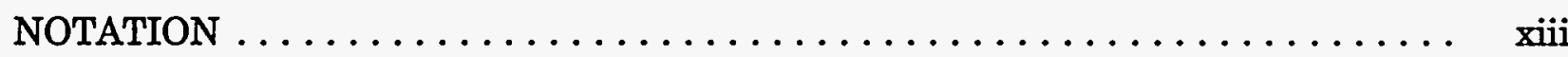

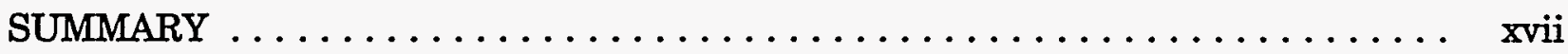

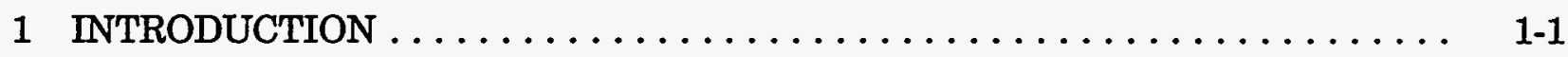

2 ENVIRONMENTAL CONDITIONS AT J-FIELD $\ldots \ldots \ldots \ldots \ldots \ldots \ldots .2-1$

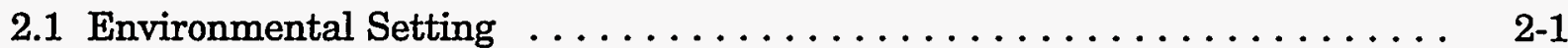

2.1.1 Surface Features $\ldots \ldots \ldots \ldots \ldots \ldots \ldots \ldots \ldots \ldots \ldots \ldots \ldots \ldots \ldots \ldots \ldots, 2-1$

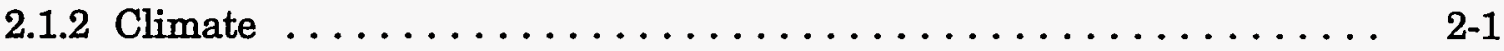

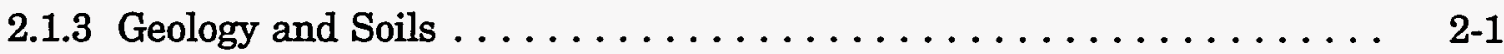

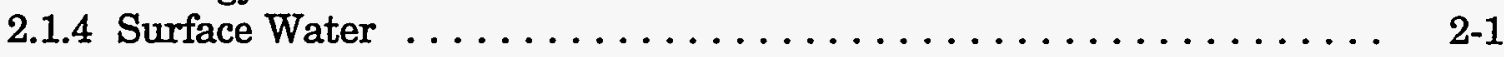

2.1.5 Groundwater $\ldots \ldots \ldots \ldots \ldots \ldots \ldots \ldots \ldots \ldots \ldots \ldots \ldots \ldots \ldots \ldots \ldots \ldots, 2-4$

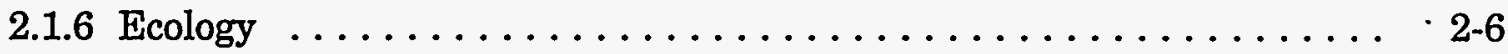

2.2 Background of J-Field Areas of Concern $\ldots \ldots \ldots \ldots \ldots \ldots \ldots \ldots .2-7$

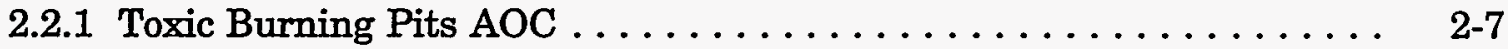

2.2.2 White Phosphorus Burning Pits AOC . . . . . . . . $\ldots \ldots \ldots \ldots$ 2-9

2.2.3 Riot Control Burning Pit AOC $\ldots \ldots \ldots \ldots \ldots \ldots \ldots \ldots \ldots \ldots .2-10$

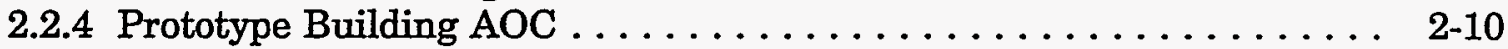

2.2.5 South Beach Demolition Ground AOC .............. 2-11

2.2.6 South Beach Trench AOC $\ldots \ldots \ldots \ldots \ldots \ldots \ldots \ldots \ldots \ldots .2-11$

2.2.7 Robins Point Demolition Ground AOC $\ldots \ldots \ldots \ldots \ldots \ldots \ldots \ldots$ 2-11

2.2.8 Robins Point Tower Site AOC $\ldots \ldots \ldots \ldots \ldots \ldots \ldots \ldots \ldots \ldots .2-12$

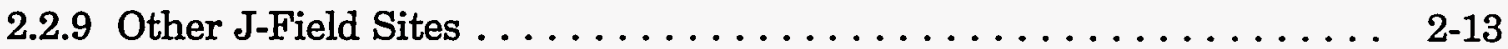

2.3 Preliminary Evaluation of J-Field Areas of Concern $\ldots \ldots \ldots \ldots \ldots \ldots$ 2-13

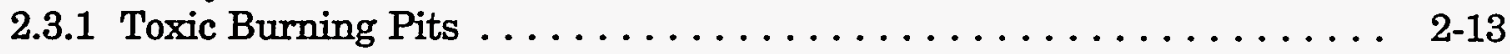

2.3.2 White Phosphorus Burning Pits $\ldots \ldots \ldots \ldots \ldots \ldots \ldots \ldots \ldots, 2-45$

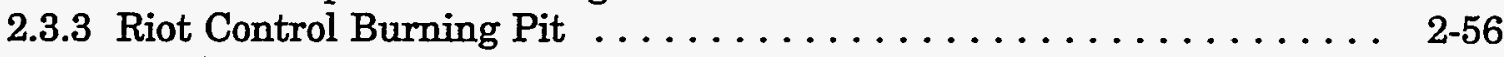

2.3.4 South Beach Trench .................... 2-64

2.3.5 South Beach Demolition Ground $\ldots \ldots \ldots \ldots \ldots \ldots \ldots \ldots \ldots$ 2-66

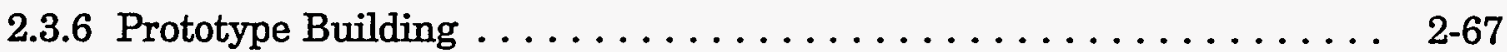

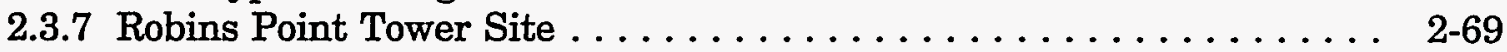

2.3.8 Robins Point Demolition Ground $\ldots \ldots \ldots \ldots \ldots \ldots \ldots \ldots \ldots .2-71$

3 CONTAMINANTS OF CONCERN, EXPOSURE PATHWAYS, AND

PRINCIPAL RECEPTORS . . . . . . . . . . . . . . . . . . . . .

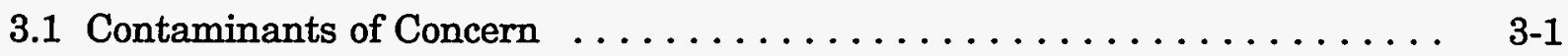

3.2 Exposure Pathways . . . . . . . . . . . . . .

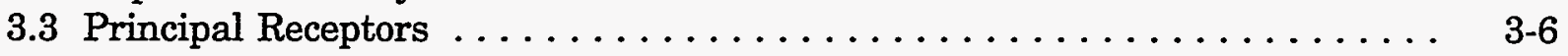




\section{CONTENTS (Cont.)}

4 OBJECTIVES AND SCOPE OF THE RISK ASSESSMENT . . . . . . . . . . 4-1

4.1 General Approach $\ldots \ldots \ldots \ldots \ldots \ldots \ldots \ldots \ldots \ldots \ldots \ldots \ldots \ldots \ldots \ldots$. . . . . . . . . .

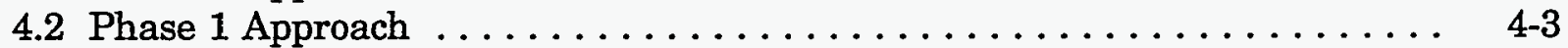

4.3 Phase 2 Approach $\ldots \ldots \ldots \ldots \ldots \ldots \ldots \ldots \ldots \ldots \ldots \ldots \ldots \ldots$

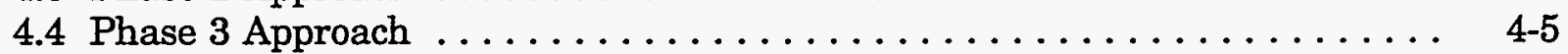

4.5 Risk Evaluation $\ldots \ldots \ldots \ldots \ldots \ldots \ldots \ldots \ldots \ldots \ldots \ldots \ldots \ldots$

4.6 Consultations $\ldots \ldots \ldots \ldots \ldots \ldots \ldots \ldots \ldots \ldots \ldots \ldots \ldots \ldots$

4.7 Report Preparation $\ldots \ldots \ldots \ldots \ldots \ldots \ldots \ldots \ldots \ldots \ldots \ldots \ldots \ldots \ldots$

5 SAMPLING AND ANALYSIS $\ldots \ldots \ldots \ldots \ldots \ldots \ldots \ldots \ldots \ldots \ldots \ldots$

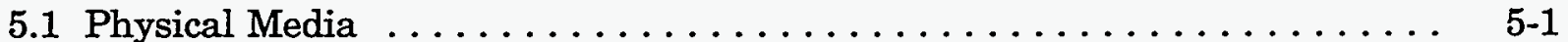

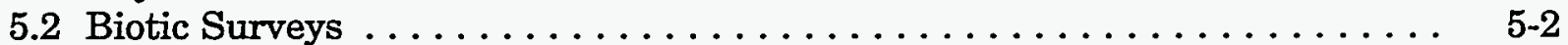

5.2.1 Terrestrial Habitats . . . . . . . . . . . . . . . . . . 5-2

5.2 .2 Open Water Habitats . . . . . . . . . . . . . . . . . . . 5-3

5.2 .3 Wetland Habitats . . . . . . . . . . . . . . . . . . . 5-4

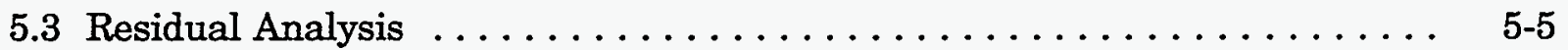

5.4 Toxicity Testing . . . . . . . . . . . . . . . . . . . . . . $5-5$

5.4.1 Acute and Chronic Toxicity Testing . . . . . . . . . . . . .

5.4 .2 Definitive Toxicity Testing . . . . . . . . . . . $\ldots \ldots \ldots \ldots \ldots$

5.5 Reference Site Selection $\ldots \ldots \ldots \ldots \ldots \ldots \ldots \ldots \ldots \ldots \ldots \ldots \ldots$

5.6 Sample Locations and Numbers $\ldots \ldots \ldots \ldots \ldots \ldots \ldots \ldots \ldots \ldots$

5.6 .1 Toxic Burning Pits . . . . . . . . . . . . . . . . . 5-10

5.6.2 White Phosphorus Burning Pits ................ 5-11

5.6 .3 Riot Control Burning Pit . . . . . . . . . . . . . . . . 5-16

5.6 .4 Prototype Building ... . . . . . . . . . . . . . . . . . . . 5-19

5.6.5 South Beach Trench . . . . . . . . . . . . . . . . . 5 5-21

5.6.6 South Beach Demolition Ground ... . . . . . . . . . . . . 5 5-23

5.6.7 Robins Point Demolition Ground . . . . . . . . . . . . . . . . . 5-24

5.6 .8 Robins Point Tower Site . . . . . . . . . . . . . . . 5-27

5.6 .9 Other J-Field Sites . . . . . . . . . . . . . . . . . . 5-27

6 RECORDS MANAGEMENT ....................... $6-1$

6.1 Quality Assurance/Quality Control Measures . . . . . . . . . . . 6-1

6.2 Technical Data Management ........................ 6-1

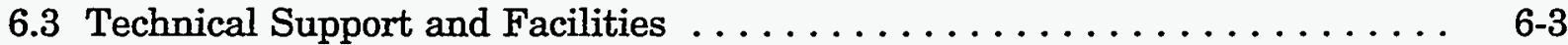

7 DATA PRESENTATION, ANALYSIS, AND INTERPRETATION $\ldots \ldots \ldots \ldots$

7.1 Introduction $\ldots \ldots \ldots \ldots \ldots \ldots \ldots \ldots \ldots \ldots \ldots \ldots \ldots \ldots \ldots \ldots \ldots$

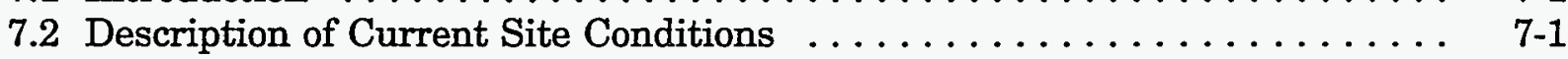

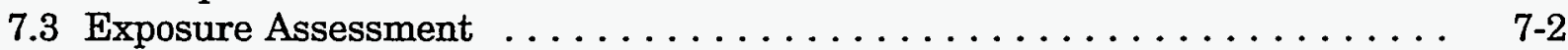

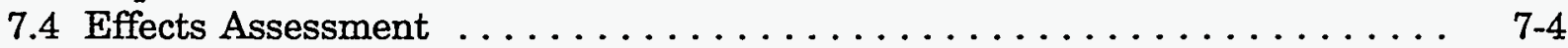

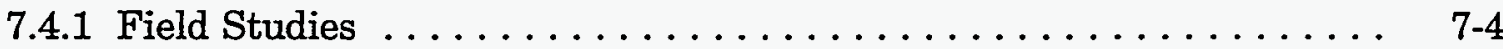

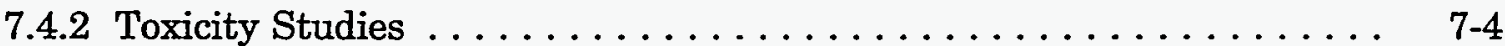


CONTENTS (Cont.)

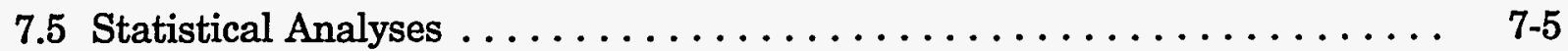

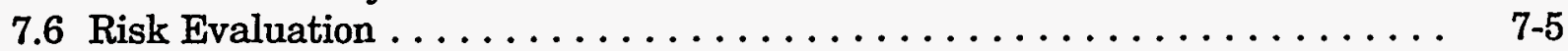

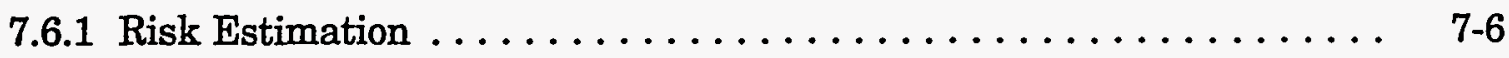

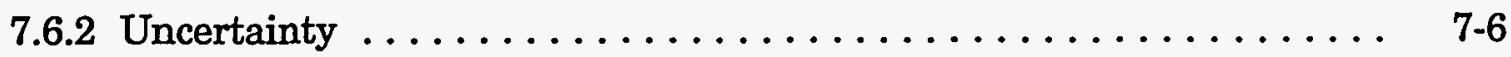

7.6.3 Ecological Significance ..................... $7-6$

7.7 Final Report $\ldots \ldots \ldots \ldots \ldots \ldots \ldots \ldots \ldots \ldots \ldots \ldots \ldots \ldots \ldots \ldots \ldots \ldots \ldots .7$

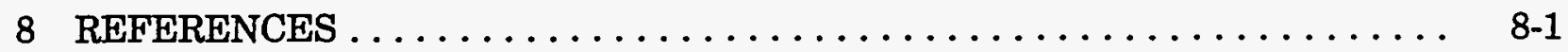

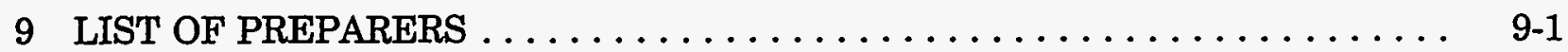

APPENDIX A: Methods for Evaluating Biological Processes

in Soil at J-Field $\ldots \ldots \ldots \ldots \ldots \ldots \ldots \ldots \ldots \ldots \ldots \ldots \ldots \ldots \ldots \ldots$

APPENDIX B: Sampling of Sediments from Bomb Craters at J-Field ....... B-1

\section{FIGURES}

1.1 Location of J-Field in the Edgewood Area at APG $\ldots \ldots \ldots \ldots \ldots \ldots \ldots$

2.1 Topography of the J-Field Area $\ldots \ldots \ldots \ldots \ldots \ldots \ldots \ldots \ldots \ldots .2-2$

2.2 Locations of Woods, Marshes, Ponds, Open Fields, and

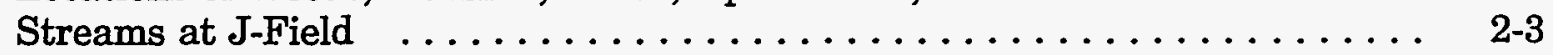

2.3 Groundwater Flow in the Surficial Aquifer, November $1989 \ldots \ldots \ldots \ldots .2-5$

2.4 Locations of Areas of Concern and Principal Site

Features at J-Field $\ldots \ldots \ldots \ldots \ldots \ldots \ldots \ldots \ldots \ldots \ldots \ldots \ldots \ldots \ldots \ldots \ldots \ldots \ldots, 2-8$

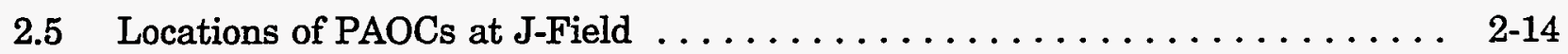

2.6 Relative Contours for all Soil-Gas Parameters

at the Toxic Burning Pits Area $\ldots \ldots \ldots \ldots \ldots \ldots \ldots \ldots \ldots \ldots \ldots \ldots \ldots . .2-18$

2.7 Relative Contours for Alkanes in Soil Gas from the Toxic

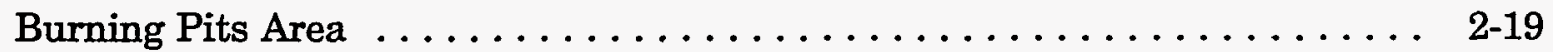

2.8 Relative Contours for Combined TRCLE and TCLEE at the

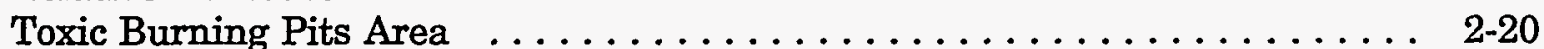

2.9 Relative Contours for Heavy Aromatics in Soil Gas from the

Toxic Burning Pits Area 


\section{FIGURES (Cont.)}

2.10 Locations in the Toxic Burning Pits Area where Surface Soil and Surface Water Samples Were Collected during the 1986 RCRA Facility Assessment . . . . . . . . . . . . . . . . . . 2-23

2.11 Locations where Soil Samples Were Collected by the USGS

in 1991.

2.12 Locations of Soil Sampling Conducted by Weston in 1992

in the Toxic Burning Pits AOC

2.13 Locations of Surface Water Samples Collected from the

Gunpowder River and Chesapeake Bay in the Immediate

Vicinity of J-Field in 1988

$2-34$

2.14 Locations of Nearshore Surface Water and Sediment

Samples Collected from around the J-Field Peninsula in 1992

$2-35$

2.15 Locations of All Wells Installed at J-Field $\ldots \ldots \ldots \ldots \ldots \ldots \ldots \ldots . \ldots \ldots$

2.16 Contours of TRCLE Concentrations in the Surficial Aquifer . . . . . . . 2-42

2.17 Locations of Soil Borings at the White Phosphorus Pits $\ldots \ldots \ldots \ldots .2-46$

2.18 Locations of Surface Soil and Surface Water Samples

in the White Phosphorus Pits Area $\ldots \ldots \ldots \ldots \ldots \ldots \ldots \ldots \ldots . .2-49$

2.19 Relative Flux Contours of Heavy Aromatics at the Riot

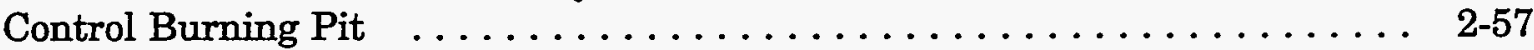

2.20 Locations of Soil Samples Collected by Weston in 1992

from the Riot Control Burning Pit

3.1 Decision Path for Selection of Preliminary Ecological

Contaminants of Concern for J-Field $\ldots \ldots \ldots \ldots \ldots \ldots \ldots \ldots \ldots, 3-4$

3.2 Ecological Conceptual Site Model for J-Field $\ldots \ldots \ldots \ldots \ldots \ldots \ldots \ldots$

4.1 Phased Approach Proposed for J-Field Ecological

Risk Assessment $\ldots \ldots \ldots \ldots \ldots \ldots \ldots \ldots \ldots \ldots \ldots \ldots \ldots, 4-2$

5.1 Proposed Surface Water and Sediment Sampling Sites

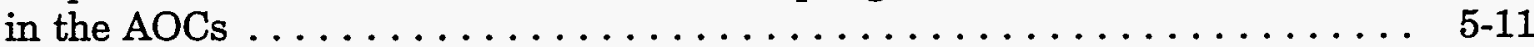

5.2 Surface Soil Sampling Area at the TBP AOC $\ldots \ldots \ldots \ldots \ldots \ldots \ldots \ldots$

5.3 Surface Soil Sampling Areas at the WPP AOC $\ldots \ldots \ldots \ldots \ldots \ldots \ldots$ 


\section{FIGURES (Cont.)}

5.4 Soil Sampling Locations at the RCP AOC $\ldots \ldots \ldots \ldots \ldots \ldots \ldots \ldots$

5.5 Surface Soil Sampling Locations at the PB AOC $\ldots \ldots \ldots \ldots \ldots \ldots . \quad 5-20$

5.6 Surface Soil Sampling Locations at the RPDG AOC $\ldots \ldots \ldots \ldots \ldots \ldots$

5.7 Surface Soil Sampling Area at the RPTS AOC $\ldots \ldots \ldots \ldots \ldots \ldots \ldots$

6.1 Overview of Data Flow for the J-Field ERA Project $\ldots \ldots \ldots \ldots \ldots \ldots$ 6-2

B.1 Potential Sampling Areas Known to Contain Bomb Craters,

Based upon Aerial Photographs and Field Observations ........... B-2

\section{TABLES}

2.1 Summary of Previous Investigations at J-Field $\ldots \ldots \ldots \ldots \ldots \ldots \ldots .2-15$

2.2 Analytical Results for Analysis of Soil Samples from the

Toxic Burning Pits AOC Main Burning Pits, January 1983

2.3 Analytical Results for Analysis of Soil Samples J1-J20 from the

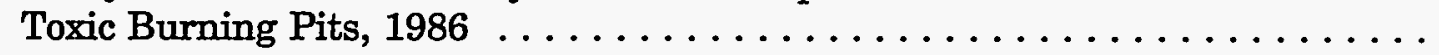

2.4 Analytical Results for Analysis of Soil Samples from the

Toxic Burning Pits Area, April $1991 \ldots \ldots \ldots \ldots \ldots \ldots \ldots \ldots \ldots \ldots .2-27$

2.5 Analytical Results for Target Compound List Analytes in

Selected Soil Samples from the Toxic Burning Pits, $1992 \ldots \ldots \ldots \ldots \ldots$ 2-29

2.6 Analytical Results for Target Analyte List Analytes in

Selected Soil Samples from the Toxic Burning Pits, $1992 \ldots \ldots \ldots \ldots \ldots$. 2-31

2.7 Analytical Results for Surface Water Samples from the

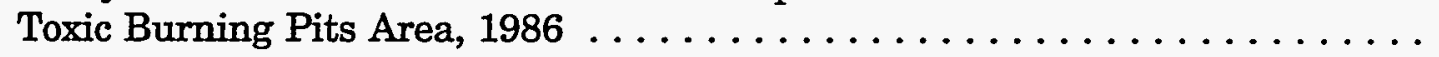

2.8 Analytical Results for Groundwater from the P-Series

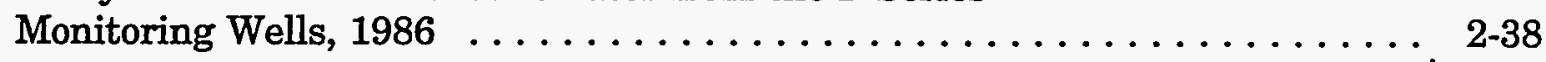

2.9 Analytical Results for Selected Inorganic Compounds, TOC, and Metals in Groundwater from the Toxic Burning Pits, 1990

2.10 Analytical Results for Selected VOCs in Groundwater from the Toxic Burning Pits Area, 1990 


\section{TABLES (Cont.)}

2.11 Analytical Results for Organosulfur and Explosives-Related Compounds in Groundwater from the Toxic Burning Pits

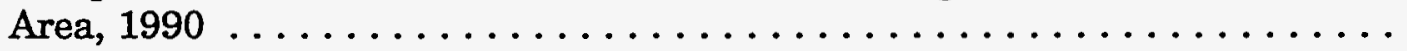

2.12 Analytical Results for Selected VOCs in Groundwater

Samples from the Toxic Burning Pits Area, $1992 \ldots \ldots \ldots \ldots \ldots \ldots \ldots$. 2-44

2.13 Concentrations of Chemical Parameters in Soil from the

White Phosphorus Pits at J-Field $\ldots \ldots \ldots \ldots \ldots \ldots \ldots \ldots \ldots \ldots, 2-48$

2.14 Analytical Results for Soil Samples J31 and J32 from

the White Phosphorous Pits, $1986 \ldots \ldots \ldots \ldots \ldots \ldots \ldots \ldots \ldots .2-50$

2.15 Analytical Results for Soil Samples from the White

Phosphorus Pits Area, April $1991 \ldots . \ldots \ldots \ldots \ldots \ldots \ldots \ldots \ldots \ldots$. 2-51

2.16 Analytical Results for TCL and TAL Analytes in Selected

Soil Samples from the White Phosphorus Pits, $1992 \ldots \ldots \ldots \ldots \ldots \ldots$. . . . 2-52

2.17 Analytical Results for Surface Water Samples from the

White Phosphorus Pits Area, 1986 . . . . . . . . . . . . . . . . . . 2-54

2.18 Analytical Results for Soil Samples from the Riot

Control Burning Pit Area, April $1991 \ldots \ldots \ldots \ldots \ldots \ldots \ldots \ldots \ldots .2-58$

2.19 Analytical Results for TCL Analytes in Selected Soil Samples

from the Riot Control Burning Pit Area, $1992 \ldots \ldots \ldots \ldots \ldots \ldots \ldots .2-60$

2.20 Analytical Results for TAL Analytes in Selected Soil Samples

from the Riot Control Burning Pit Area, $1992 \ldots \ldots \ldots \ldots \ldots \ldots \ldots . . .62$

3.1 Summary of Chemicals of Potential Concern for J-Field . . . . . . . . . 3-2

3.2 Status of Contaminants of Potential Concern by Area of Concern

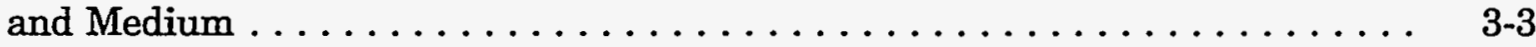

3.3 Preliminary List of Ecological Receptors for J-Field . . . . . . . . . . . . . 3-7

5.1 Contract Laboratory Program Analytical Suite $\ldots \ldots \ldots \ldots \ldots \ldots \ldots . \quad 5-2$

5.2 Summary of Bioassays Selected for Use at J-Field $\ldots \ldots \ldots \ldots \ldots \ldots \ldots$

5.3 Approximate Numbers of the First Round of Stage I

Samples Required, by Media and by Area of Concern .............. 5-13

5.4 Biotic Surveys Proposed for the Toxic Burning Pits AOC $\ldots \ldots \ldots \ldots \ldots$ 5-14 


\section{TABLES (Cont.)}

5.5 Biotic Surveys Proposed for the White Phosphorus Burning

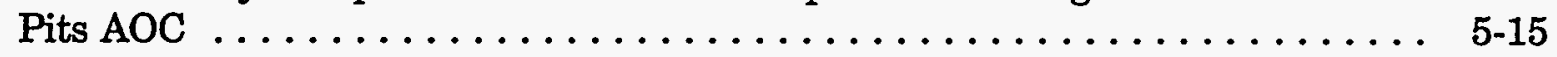

5.6 Biotic Surveys Proposed for the Riot Control Burning Pit AOC $\ldots \ldots \ldots \ldots$ 5-18

5.7 Biotic Surveys Proposed for the Prototype Building AOC $\ldots \ldots \ldots \ldots \ldots$ 5-21

5.8 Biotic Surveys Proposed for the South Beach Trench AOC $\ldots \ldots \ldots \ldots \ldots$ 5-22

5.9 Biotic Surveys Proposed for the South Beach Demolition

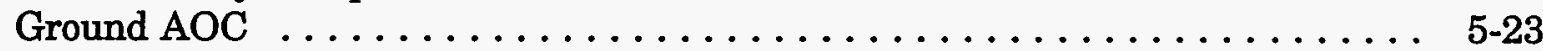

5.10 Biotic Surveys Proposed for the Robins Point Demolition

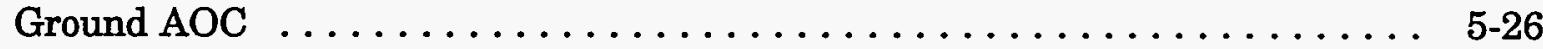

5.11 Biotic Surveys Proposed for the Robins Point Tower Site AOC . . . . . . . . 5-29 


\section{FOREWORD}

This document presents the work plan for conducting an ecological risk assessment as part of a remedial investigation/feasibility study (RI/FS) to be carried out at J-Field, Aberdeen Proving Ground, Maryland, pursuant to the Comprehensive Environmental Response, Compensation, and Liability Act (CERCLA), as amended. The RI/FS is to be conducted for the U.S. Army under the direction of the Directorate of Safety, Health, and Environment, Aberdeen Proving Ground. This report is one in a series of documents being prepared to define the plans for RI/FS activities at J-Field. Other documents in this series include a Remedial Investigation Work Plan (Benioff et al. 1995a); a Field Sampling Plan (Benioff et al. 1995b); a Quality Assurance Project Plan (Prasad et al. 1995); and a Work Plan for the Focused Feasibility Study (FFS) of the Toxic Burning Pits Area (Biang et al. 1995). A Work Plan for the Feasibility Study for Remedial Action is in preparation. 


\section{NOTATION}

The following is a list of the acronyms, initialisms, and abbreviations (including chemicals and units of measure) used in this document.

\section{ACRONYMS, INITIALISMS, AND ABBREVIATIONS}

$\mathrm{ADD}$

ANL

AOC

APG

ARAR

ASTM

AWQC

BTAG

CERCLA

CFR

CLP

CLPAS

COE

CRDEC

CWA

DNAPL

DSHE

EEQ

EMD

EP

EPA

ERA

ERT

FFS

FS

FSP

GIS

GPR

GPS

HE

HII

IRDMS

IRP applied daily dose

Argonne National Laboratory

area of concern

Aberdeen Proving Ground applicable or relevant and appropriate requirement American Society for Testing and Materials ambient water quality criterion

Biological Technical Assistance Group

Comprehensive Environmental Response, Compensation, and

Liability Act (as amended)

Code of Federal Regulations

Contract Laboratory Program

Contract Laboratory Program Analytical Suite

U.S. Army Corps of Engineers

Chemical Research, Development, and Engineering Center

chemical warfare agent

dense, nonaqueous phase liquid

Directorate of Safety, Health, and Environment

environmental effect quotient

Environmental Management Division (Aberdeen Proving Ground)

extraction procedure

U.S. Environmental Protection Agency

ecological risk assessment

emergency response team

Focused Feasibility Study

Feasibility Study

Field Sampling Plan

geographic information system

ground-penetrating radar

global positioning system

high explosives

hazard index

Installation Restoration Data Management System

Installation Restoration Program 
$\mathrm{LC}_{50} \quad$ lethal concentration at which $50 \%$ of test organisms die

MATC

MCL

MDE

MSL

NAPL

NCP

ND

NOAEL

NPL

OB

$O D$

PAOC

$\mathrm{PB}$

QA

QAPjP

QC

RCP

RCRA

RFA

RI

RI/FS

RPDG

RPTS

SARA

SBDG

SBT

SOP

TAL

TBD

TBP

TCL

USAEHA

USATHAMA

USGS

UXO

WPP

$\mathrm{XRF}$ maximum allowable tissue concentration maximum contaminant level

Maryland Department of the Environment mean sea level

nonaqueous phase liquid

National Contingency Plan

not detected

no-observed-adverse-effects level

National Priorities List

open burning

open detonation

potential area of concern

Prototype Building

quality assurance

Quality Assurance Project Plan

quality control

Riot Control Burning Pit

Resource Conservation and Recovery Act (as amended)

RCRA Facility Assessment

remedial investigation

remedial investigation/feasibility study

Robins Point Demolition Ground

Robins Point Tower Site

Superfund Amendments and Reauthorization Act

South Beach Demolition Ground

South Beach Trench

standard operating procedure

Target Analyte List

to be determined

Toxic Burning Pits

Target Compound List

U.S. Army Environmental Hygiene Agency

U.S. Army Toxic and Hazardous Materials Agency

U.S. Geological Survey

unexploded ordnance

White Phosphorus Burning Pits

$\mathrm{X}$-ray fluorescence 


\section{ABBREVIATIONS FOR CHEMICALS}

BNA

BTEX

C2H3CL

$\mathrm{C} 6 \mathrm{H} 6$

CHCL3

CK

$\mathrm{CN}$

CS

DANC

DCE

11DCE

12DCE

trans-12DCE

DDD

DDE

DDT

$\mathrm{DM}$

DNT

FM

FS

HMX

$\mathrm{PAH}$

PCB

PETN

PWP

$\mathrm{RDX}$

Sr-90

TCE

111TCE

112TCE

TCLEA

TCLEE

TDS

TEX

TKN

TNT

TOC

TOX

TRCLE base neutral and acid extractable organic compounds

benzene, toluene, ethylbenzene, and xylenes

vinyl chloride

benzene

chloroform

cyanogen chloride

chloroacetophenone

o-chlorobenzylidene malononitrile/orthochlorobenzalmalononitrile

decontaminating agent, noncorrosive

dichloroethylene

1,1-dichloroethylene

1,2-dichloroethylene

trans-1,2-dichloroethylene

dichlorodiphenyldichloroethane

dichlorodiphenyldichloroethylene

dichlorodiphenyltrichloroethane

adamsite

dinitrotoluene

titanium tetrachloride

sulfur trioxide/chlorosulfonic acid

cyclotetramethylene tetranitrate

polyaromatic hydrocarbon

polychlorinated biphenyl

penta-erythritol tetranitrate

plasticized white phosphorus

hexahydro-1,3,5-trinitro-1,3,4-triazine

strontium-90

trichloroethane

1,1,1-trichloroethane

1,1,2-trichloroethane

1,1,2,2-tetrachloroethane

tetrachloroethylene

total dissolved solids

toluene, ethylbenzene, and xylenes

total Kjeldahl nitrogen

trinitrotoluene

total organic carbon

total organic halogen

trichloroethylene 
VOC volatile organic compound

$\mathrm{VX}$ methylphosphonothioic acid, a nerve agent = o-ethyl S-(2-diisopropylaminoethyl methylphosphonothioate)

WP white phosphorus

\section{UNITS OF MEASURE}

$\begin{array}{ll}\mathrm{d} & \text { day(s) } \\ { }^{\circ} \mathrm{C} & \text { degree(s) Celsius } \\ { }^{\circ} \mathrm{F} & \text { degree(s) Fahrenheit } \\ \mathrm{ft} & \text { foot (feet) } \\ \mathrm{ft}^{2} & \text { square foot (feet) } \\ \mathrm{g} & \text { gram(s) } \\ \mathrm{kg} & \text { kilogram(s) } \\ \mathrm{\mu g} & \text { microgram(s) } \\ \mathrm{mg} & \text { milligram(s) } \\ \mathrm{gal} & \text { gallon(s) } \\ \mathrm{ha} & \text { hectare(s) } \\ \mathrm{in} . & \text { inch(es) } \\ \mathrm{L} & \text { liter(s) } \\ \mathrm{lb} & \text { pound(s) } \\ \mathrm{m} & \text { meter(s) } \\ \mathrm{mi} & \text { mile(s) } \\ \mathrm{min} & \text { minute(s) } \\ \mathrm{pCi} & \text { picocurie(s) } \\ \mathrm{ppb} & \text { part(s) per billion } \\ \mathrm{ppm} & \text { part(s) per million } \\ \mathrm{yd} & \text { yard(s) }\end{array}$




\section{SUMMARY}

The Environmental Management Division of Aberdeen Proving Ground (APG), Maryland, is conducting a remedial investigation and feasibility study (RI/FS) of the J-Field area at APG pursuant to the Comprehensive Environmental Response, Compensation, and Liability Act (CERCLA), as amended. J-Field is within the Edgewood Area of APG in Harford County, Maryland, and activities at the Edgewood Area since World War II have included the development, manufacture, testing, and destruction of chemical agents and munitions. The J-Field site was used to destroy chemical agents and munitions by open burning and open detonation (OB/OD). This work plan presents the approach proposed to conduct an ecological risk assessment (ERA) as part of the RI/FS program at J-Field. This work plan identifies the locations and types of field studies proposed for each area of concern (AOC), the laboratory studies proposed to evaluate toxicity of media, and the methodology to be used in estimating doses to ecological receptors and discusses the approach that will be used to estimate and evaluate ecological risks at J-Field. Eight AOCs have been identified at J-Field, and the proposed ERA is designed to evaluate the potential for adverse impacts to ecological receptors from contaminated media at each AOC, as well as over the entire J-Field site. The proposed ERA approach consists of three major phases, incorporating field and laboratory studies as well as modeling.

Phase 1 of the ERA includes biotic surveys of the aquatic and terrestrial habitats, biological tissue sampling and analysis, and media toxicity testing at each $\mathrm{AOC}$ and appropriate reference locations. Qualitative and quantitative surveys will be conducted for wetland and terrestrial vegetation, soil and benthic invertebrates, fish, reptiles and amphibians, small mammals, and birds. Surveys of soil processes, such as nitrogen mineralization, litter decomposition, and enzyme activation, will also be conducted. The surveys will provide baseline information on the current status of the ecological resources at J-Field, identify important ecologial resources (if present) such as endangered species, and identify adverse ecological effects that have occurred or are currently occurring at J-Field. Contaminant exposure will be estimated by tissue analysis of biological samples from selected species or groups. Toxicity of media from each AOC and reference locations will be evaluated with a variety of aquatic, sediment, and soil toxicity tests using algae, terrestrial vegetation, invertebrates, fish, and amphibians as test organisms. The results of the Phase 1 activities, along with data from the chemical characterization activities under way at the site, will be evaluated to determine whether adverse ecological effects are occurring, or have the potential to occur, at J-Field. If adverse effects are observed or suspected, Phase 2 ERA activities will be initiated. Phase 1 will also serve to identify the ecological receptors that will be evaluated in detail in the ERA.

Phase 2 of the ERA includes definitive toxicity testing of media from areas of known or suspected contamination or of media for which the Phase 1 results indicate toxicity or adverse ecological effects. The definitive toxicity tests, which evaluate toxicity of serial dilutions of media, will provide dose-response relationships for toxicity and media concentration. Phase 2 will also include additional biological sampling for tissue analysis. Pathway analysis, using data from the Phase 1 biotic surveys and tissue analyses, will be

$$
\text { xvii }
$$

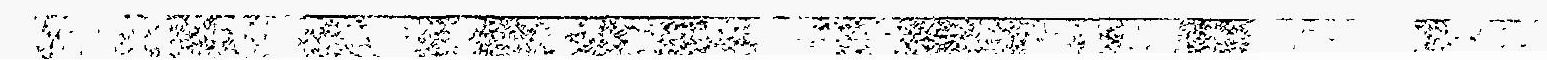


conducted to develop preliminary contaminant exposure and uptake models for selected receptor species. These models, which will include considerations of food chain transport of contaminants, will allow predictions of contaminant dose to higher trophic level receptors, such as birds of prey, waterfowl, and large mammals, that may utilize the J-Field site. The results of Phase 1 and Phase 2 studies will be used in the development of these site-specific models.

In Phase 3 of the ERA, the uptake models initially developed in Phase 2 for each ecological receptor will be finalized, and contaminant dose to each receptor from all complete pathways will be estimated. Principal exposure pathways will include ingestion of food, surface water, soil, and, possibly, dermal uptake and inhalation. Monte Carlo uncertainty analysis will be used to evaluate uncertainty associated with the model estimates. Phase 3 will also include the development of benchmark toxicity values against which the dose estimates will be compared for risk evaluation.

Upon completion of Phase 1, 2, and 3 activities, a risk evaluation will be performed to characterize the risk to ecological resources from the current levels of contamination at J-Field. This risk evaluation will be conducted for J-Field as a whole and separately for each AOC. Ecological risk will be evaluated by estimating an environmental effect quotient for each contaminant of concern and each ecological receptor. Risk will also be evaluated by a weight-of-evidence approach, which considers the results of all the laboratory and field studies. The risk evaluation will present an uncertainty discussion for all components of the ERA and discuss the ecological significance of any observed or predicted risks.

The results of all field and laboratory activities, dose modeling, uncertainty analyses, and risk evaluation will be presented in a final ERA report. That report will include (1) the identification of the ecological contaminants of concern, (2) the identification of ecological receptors and their exposure pathways, (3) a description of the field and laboratory methods used in performing the exposure and effects assessments, (4) a summary of the chemical and biological data, (5) a description of the risk estimation approach and results, (6) a discussion of the uncertainty associated with the assessment, and (7) a determination of the ecological significance of the predicted risks. 


\section{INTRODUCTION}

This work plan presents the approach proposed to conduct an ecological risk assessment (ERA) as part of a remedial investigation/feasibility study (RI/FS) at eight areas of J-Field in the Edgewood Area of Aberdeen Proving Ground (APG) in Harford County, Maryland (Figure 1.1). The J-Field sites were used for the testing, disposal, and destruction by burning of a variety of hazardous chemicals. The ERA will (1) determine whether any observable adverse ecological effects are present from site contamination; (2) evaluate whether contaminated site media are toxic to biota; and (3) assess whether site contamination poses an unacceptable risk to biota, habitats, or ecosystems. These findings will assist APG in determining whether, from an ecological perspective, remedial action is necessary at these sites and whether the sites host valuable biological communities that would be adversely affected by conventional remedial actions.

The Edgewood Area of APG, including J-Field, was placed on the National Priorities List (NPL) in 1990. Any remedial activities conducted there are subject to the provisions of the Comprehensive Environmental Response, Compensation, and Liability Act (CERCLA) of 1980 and its 1986 amendments (Superfund Amendments and Reauthorization Act [SARA]). The CERCLA process dictates that the U.S. Environmental Protection Agency (EPA) protect human health and the environment with respect to releases or potential releases of contaminants from abandoned hazardous waste sites. Remedial actions must be protective of ecological systems and must include some form of ecological assessment. In addition, a number of applicable or relevant and appropriate requirements (ARARs), such as the Endangered Species Act, Clean Water Act, and various state laws, could require additional considerations.

This work plan has been prepared as part of the overall RI/FS program initiated at APG in accordance with the Interagency Agreement negotiated between the U.S. Army and EPA Region III. The APG Directorate of Safety, Health, and Environment (DSHE) has contracted with Argonne National Laboratory (ANL) to conduct the ERA.

The study described in this plan is part of a larger program to delineate risks and ecological impacts from past chemical and hazardous material contamination at J-Field. These related studies are described in the following documents:

- Risk and Biological Impact Assessment at U.S. Army Aberdeen Proving Ground, Maryland, Technical Plan, Volumes I and II (ICF-Kaiser Engineers 1993a,b);

- Workplan for Conducting Human Health and Ecological Risk Assessments at the O-Field Area (ICF-Kaiser Engineers 1992); and

- Remedial Investigation Sampling and Analysis Plan for J-Field, Aberdeen Proving Ground, Maryland, Volume 1: Field Sampling Plan (Benioff et al. 1995b), hereafter referred to as the FSP. 


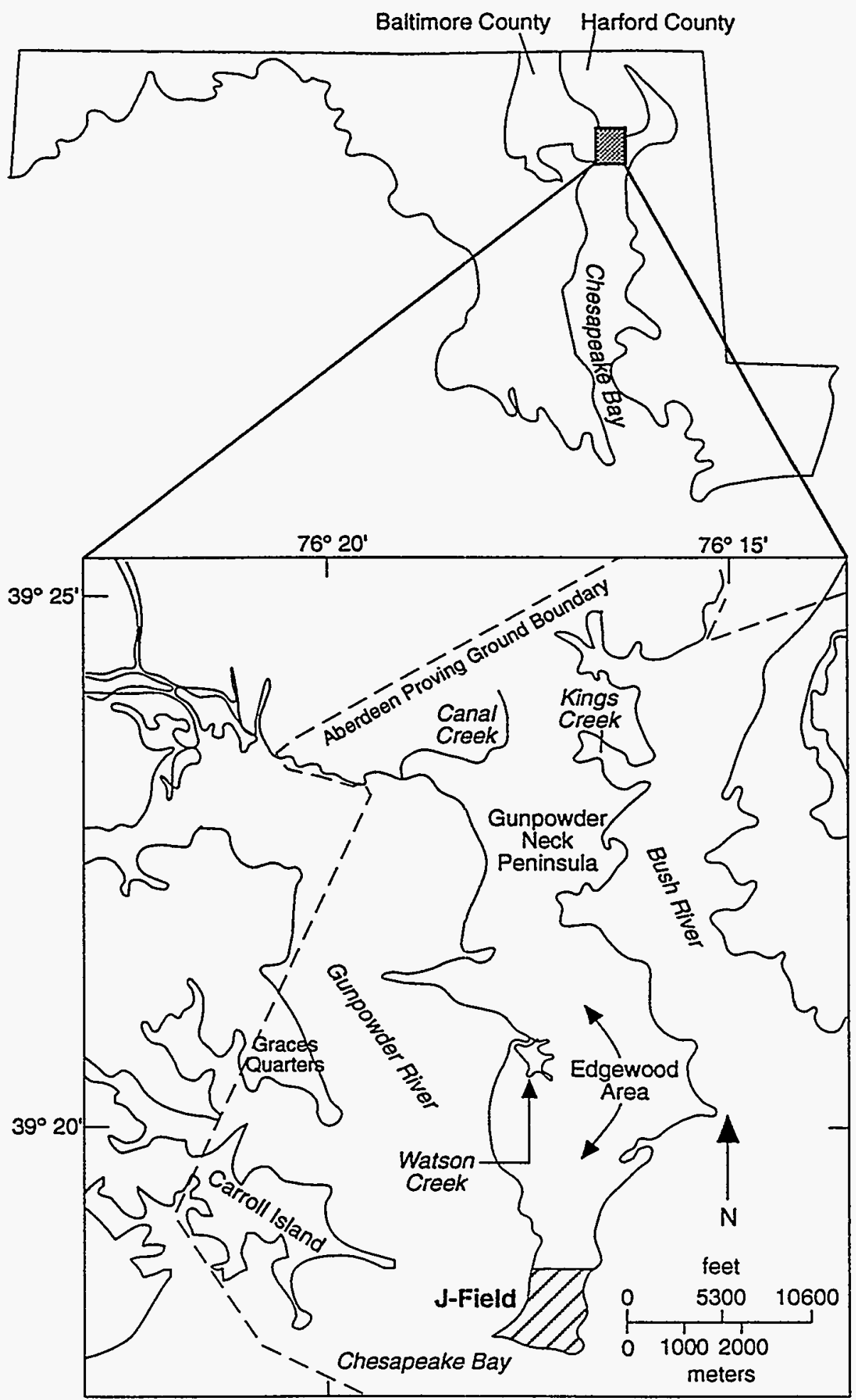

FIGURE 1.1 Location of J-Field in the Edgewood Area at APG (Source: Adapted from Hughes 1993) 
To ensure that the J-Field ERA provides information applicable to other APG assessments, this J-Field ERA work plan uses the general approach developed for APG (ICF-Kaiser Engineers 1993a). However, because this work plan is limited to the site-specific ecological properties of the J-Field area, some deviations from the general sitewide approach and O-Field assessment are necessary. In addition, the J-Field ERA will rely on the results of past, ongoing, and planned contaminant characterization studies conducted for J-Field by ANL and other organizations, such as the U.S. Geological Survey (USGS) $(1990,1991)$. The J-Field ERA studies will be conducted concurrently with the ongoing and planned contaminant characterization studies. This timing is reflected in this work plan, which contains the following:

- Section 1 provides introductory information.

- Section 2 describes the site background, including physical and ecological environment, site history, and contamination.

- Section 3 identifies potential contaminants of ecological concern, principal receptors, and exposure pathways.

- Section 4 provides the objectives of the risk assessment and discusses the scope of the proposed studies. Activities are subdivided into three analysis phases.

- Section 5 discusses field sampling and laboratory and field analyses to be performed for the risk assessment. Chemical analyses, biotic surveys, and in situ and laboratory toxicity studies are also described.

- Section 6 discusses data management, including quality assurance (QA) and quality control (QC).

- Section 7 provides the approach by which the results of the risk assessments will be analyzed and interpreted, discusses data presentation, and describes the format of the final ERA report.

- Section 8 provides references for literature cited in the text.

- Section 9 provides a list of document preparers.

- Appendix A describes methods for evaluating biological processes in soils.

- Appendix B discusses the sampling of sediments from bomb craters at J-Field. 


$$
\text { 1-4 }
$$




\section{ENVIRONMENTAL CONDITIONS AT J-FIELD}

\subsection{ENVIRONMENTAL SETTING}

\subsubsection{Surface Features}

J-Field is nearly flat, with a maximum relief of about $10 \mathrm{ft}$. The ground surface slopes gently toward marshy areas or toward Chesapeake Bay and on-site surface water. In some places, wave erosion has formed short, steep cliffs (2-10 ft high) along the shore (Hughes 1993).

Surface water occurs in demolition craters, in marsh areas, and in a few open ponds within the marshes. Between December and May water collects in wooded areas where drainage is poor because the low-permeability soils slow the rate of infiltration. Figure 2.1 shows the overall topography of the site.

\subsubsection{Climate}

The climate in the area of APG is temperate and moderately humid and is moderated by the presence of Chesapeake Bay. The average annual precipitation of 45 in. is distributed relatively uniformly during the year. The average annual temperature is about $54^{\circ} \mathrm{F}$ (Nemeth 1989; Hughes 1993).

\subsubsection{Geology and Soils}

The stratigraphy of J-Field consists of Quaternary (Talbot) sediments underlain by Cretaceous (Potomac Group) sediments. The Quaternary sediments constitute a fluvial, estuarine, and marginal marine unit of sand, gravel, and silty clay. The Cretaceous sediments are a sand and clay unit of fluvial origin.

The Quaternary sediments can be divided into three units. The surface unit consists of interbedded sand and clay.about 30-40 ft thick; the middle unit is silty, sandy clay and organic matter about 36-107 ft thick; and the base unit is gravelly sand and clay about 13-50 ft thick. The Cretaceous sediments consist of interbedded layers of fine-grained sand and massive clay. The top of this layer is at a depth of 110-160 ft. Metamorphic bedrock underlies the sediments at depths ranging from 200 to $900 \mathrm{ft}$.

\subsubsection{Surface Water}

The southern and eastern shores of J-Field are covered by an extensive marsh system (Figure 2.2). The marshes may be flooded during storms and very high tides but are 


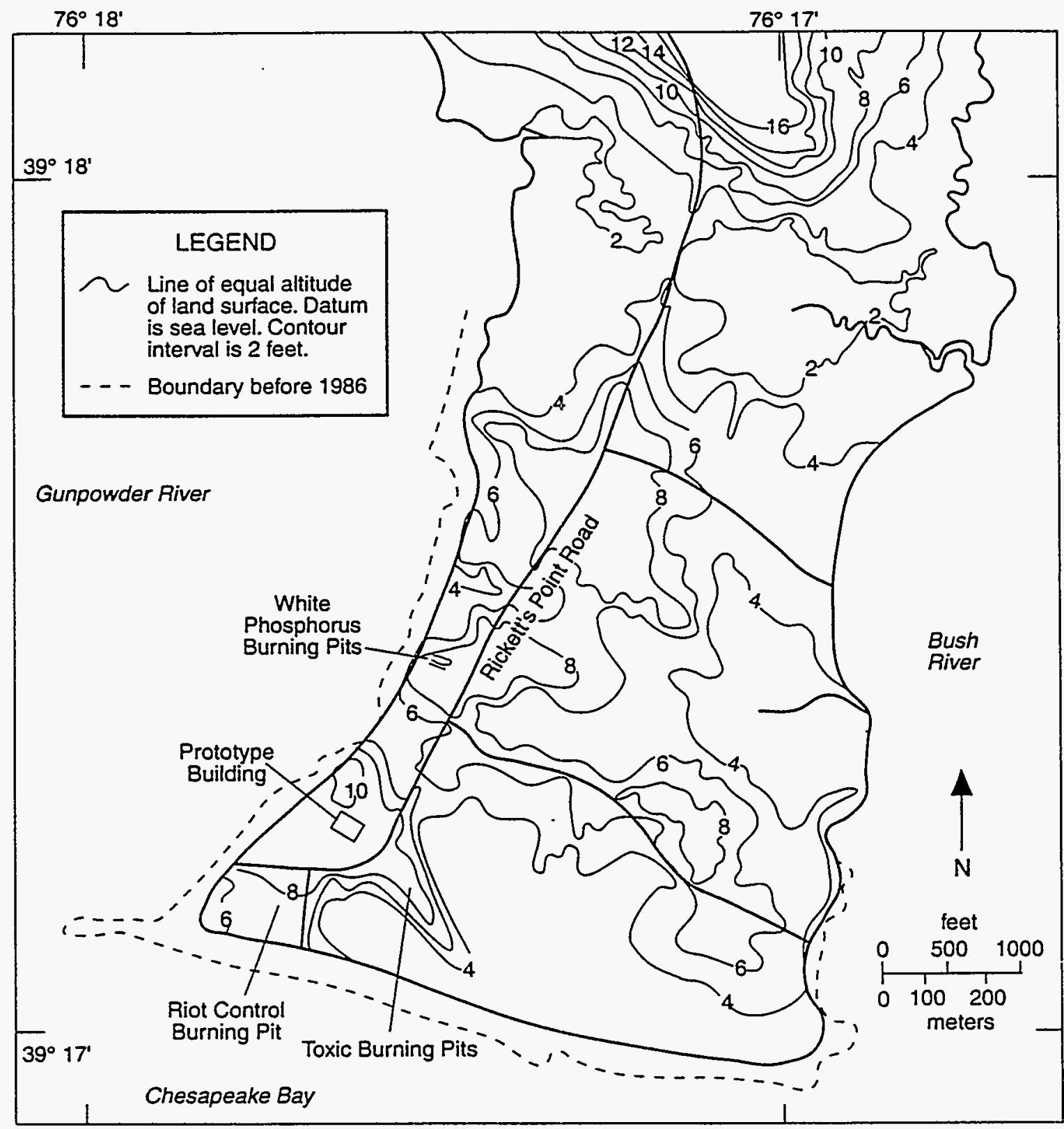

FIGURE 2.1 Topography of the J-Field Area (Source: Adapted from Hughes 1993) 


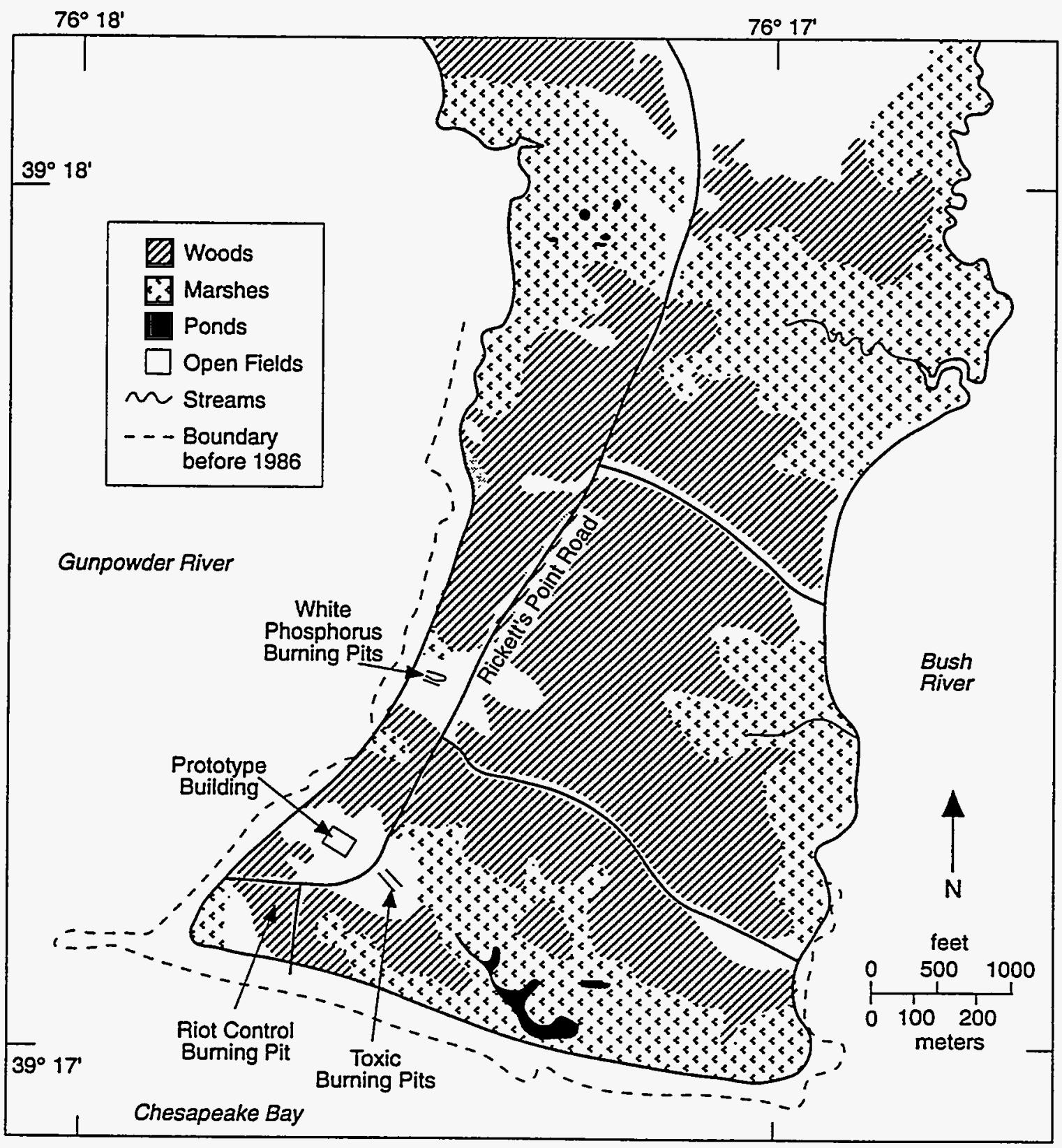

FIGURE 2.2 Locations of Woods, Marshes, Ponds, Open Fields, and Streams at J-Field (Source: Adapted from Hughes 1993) 
not affected by normal tides of 1-2 ft. The water level in the marshes is generally about $2 \mathrm{ft}$ above high tide in Chesapeake Bay. The disposal pits at J-Field originally drained into these marshes or into the Gunpowder and Bush rivers. During the 1970s, drainage from the disposal pits was blocked. Currently, surface water can be 1-2 $\mathrm{ft}$ deep in the Toxic Burning Pits (TBP) and the White Phosphorus Burning Pits (WPP) during the wet season, generally March to June (Hughes 1993). Several ponds and streams are located within the marshy areas of J-Field (Figure 2.2). The largest pond, which is about $5 \mathrm{ft} \mathrm{deep,} \mathrm{is} \mathrm{southeast} \mathrm{of} \mathrm{the}$ TBP. Two streams on the eastern side of J-Field are the only on-site streams and do not carry much runoff except during storms.

\subsubsection{Groundwater}

Four major hydrologic units have been identified beneath J-Field - the surficial aquifer (in the overlying Talbot layer), the leaky confining unit (in the middle layer), the confined aquifer (in the bottom Talbot unit), and the Potomac Group aquifer. Groundwater flow in these units is described below on the basis of current knowledge of the aquifers.

\subsubsection{Surficial Aquifer}

The surficial aquifer consists of interbedded sand and clay and corresponds to the surface unit of the Quaternary (Talbot) sediment; it ranges from 25 to $40 \mathrm{ft}$ thick, with elevations following the surface topography. The steepest hydraulic gradients were found near the TBP and WPP. Because the closest pumping of this aquifer is about 4 mi to the west, the major influences on the flow system are recharge, evapotranspiration, and tidal fluctuations. Recharge is mainly through rainfall, and the system discharges into the marshes and Chesapeake Bay. Some recharge from Chesapeake Bay may occur during droughts (Hughes 1993). Figure 2.3 shows the direction of groundwater flow in the surficial aquifer.

A general downward gradient that occurs between the water table and the leaky confining layer indicates that the leaky confining unit is recharged primarily by the surficial aquifer. During the summer, the direction of vertical flow is reversed at some locations. Groundwater under the marsh and the rivers, which are discharge areas, probably leaks upward from the leaky confining aquifer into the surficial aquifer.

\subsubsection{Leaky Confining Unit}

The leaky confining unit consists of silty, sandy clay and organic matter and corresponds to the middle unit of the Quaternary (Talbot) sediments. Vertical leakage from the leaky confining unit to the underlying confined aquifer occurs at all sites beneath J-Field but is probably quite limited offshore. The direction of vertical flow may be reversed in some offshore areas (Hughes 1993). 


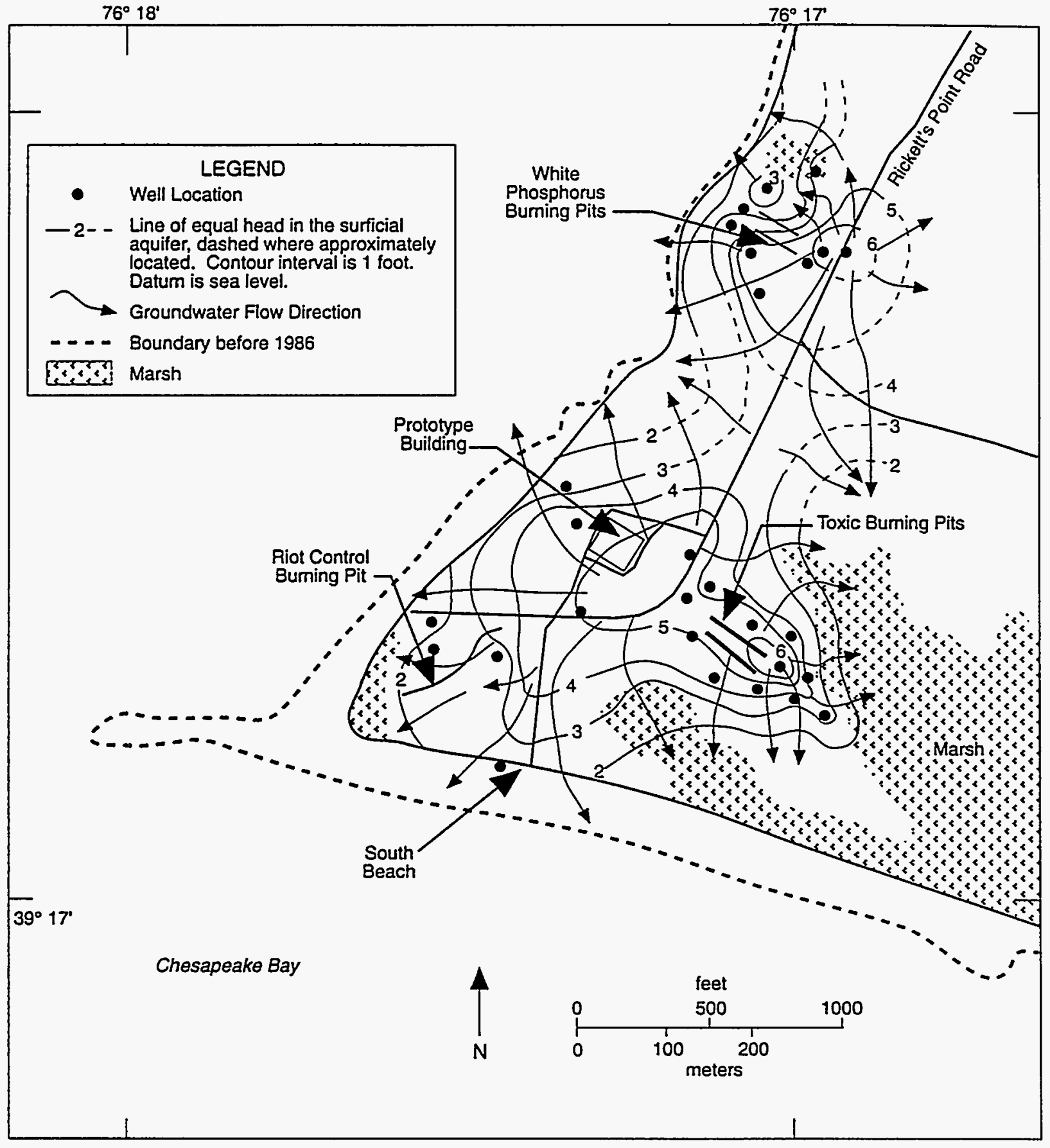

FIGURE 2.3 Groundwater Flow in the Surficial Aquifer, November 1989 (Source: Adapted from Hughes 1993) 
Lateral flow in the leaky confining unit is generally the same as that of the surficial aquifer. In the western part of the site, the unit is $40 \mathrm{ft}$ thick, with a surface elevation $25 \mathrm{ft}$ below mean sea level (MSL). In the eastern portion of the site, the unit is $107 \mathrm{ft}$ thick and has a surface elevation of $35 \mathrm{ft}$ below MSL. Hydraulic conductivities range from less than 0.01 to $0.20 \mathrm{ft} / \mathrm{d}$, with a median value of $0.05 \mathrm{ft} / \mathrm{d}$ (Hughes 1993).

\subsubsection{Confined Aquifer}

The confined aquifer consists of gravelly sand and clay and corresponds to the base unit of the Quaternary (Talbot) sediments. In the western part of J-Field, the top of the confined aquifer is $60 \mathrm{ft}$ below MSL, and the unit is $50 \mathrm{ft}$ thick. In the southeast, this aquifer dips to a surface elevation of $142 \mathrm{ft}$ below MSL and thins to $15 \mathrm{ft}$ thick. Lateral flow directions are similar to those in the water table; however, the hydraulic head and lateral gradients are very small. Groundwater flows away from the TBP toward the marshes and Chesapeake Bay, and wells show evidence of a tidal influence. Seasonal variations in the flow direction of the confined aquifer occur for short periods during the summer (Hughes 1993).

\subsubsection{Potomac Group Aquifer}

The Potomac Group aquifer consists of interbedded, fine-grained sand and massive clay. This aquifer corresponds to the Cretaceous (Potomac Group) sediments of fluvial origin. Surface elevations of the Potomac Group aquifer range from $105 \mathrm{ft}$ below MSL in the eastern part of J-Field to $157 \mathrm{ft}$ below MSL in the western part. The thickness of the aquifer is, in general, uncertain but may be up to $800 \mathrm{ft}$. The sediments are underlain by metamorphic bedrock. Insufficient data are available to determine lateral or vertical flow directions or the effects of the seasons and tides on the Potomac Group aquifer (Hughes 1993).

\subsubsection{Ecology}

Gunpowder Neck Peninsula consists primarily of open fields (mowed and unmowed grass), bare ground, and second-growth woods (dominated by maple, oaks, and sweetgum). $J$-Field supports extensive areas of these second-growth woods and freshwater wetlands (dominated by common reed). A large wetland at the southern end of J-Field (Figure 2.2) supports extensive areas of reed and includes a large area of open water. All wetlands at J-Field are separated from the Chesapeake Bay by beach ridges and thus are not directly influenced by tidal fluctuations except through changes in groundwater levels. A few areas of bare ground are located on the western and eastern sides of J-Field, particularly in the vicinity of disposal pits. Additional freshwater tidal and nontidal wetlands occur along the periphery of the Gunpowder Neck Peninsula, outside of J-Field. The peninsula is surrounded by freshwater tidal estuaries - Chesapeake Bay to the south, Gunpowder River to the west, and Bush River to the east. 
Both the TBP and the WPP areas of concern (AOCs) are in open areas cleared of natural vegetation. The area immediately around each pit consists of mowed grass with weeds typical of disturbed habitats and old fields. The TBP are west of a large wetland at the southern end of J-Field. Some of the burned material from these pits has, over time, been pushed into the wetland. The WPP are very close to the Gunpowder River. In 1986, a berm was constructed to prevent waste material from these pits from entering the river. Such material is now diverted into a wetland approximately $100 \mathrm{~m}$ north of the pits. The Riot Control Burning Pit (RCP) AOC has not been used since the early 1970s; therefore, it is presently overgrown with shrubs and reeds. It is likely that runoff from the pit enters an adjacent wetland and the Gunpowder River.

The biota at J-Field have not been surveyed in detail; however, common species are likely to include those typical of other areas of the APG (ICF-Kaiser Engineers 1993a). Mammals likely to be common at J-Field include the muskrat, raccoon, white-tailed deer, short-tailed shrew, and white-footed mouse. Common birds could include great blue heron and spotted sandpiper. Because of its status as a federal endangered species, the bald eagle (known to occur in the J-Field vicinity) is of ecological and regulatory interest. Composition of the fish communities in the J-Field wetlands has not been determined.

\subsection{BACKGROUND OF J-FIELD AREAS OF CONCERN}

The following sections summarize the past disposal operations conducted at each $\mathrm{AOC}$ at J-Field. General descriptions of the hydrology and soils in the vicinity of J-Field are also included.

\subsubsection{Toxic Burning Pits AOC}

The TBP AOC is located on about 9 acres in the southern portion of J-Field (Figure 2.4). Disposal operations at the TBP area began in the 1940s and have continued until the present. The pits were used most extensively between the late 1940s and the 1960s. Items disposed of included chemical agents, bulk chemical wastes, drummed chemical wastes, high explosives (HE) (by open burning and open detonation [OB/OD]), nerve agents, incapacitating agents (also known as riot control agents), chlorinated solvents, and blister agents (Nemeth 1989).

Information from interviews, sampling, and magnetic surveys indicates that five disposal pits were used at the TBP area. The two existing (or main) burning pits (each covering about 4,500 $\mathrm{ft}^{2}$ ) were the pits most actively used for the disposal of various chemical agents and explosives. Three other burning pits, now covered, were used to dispose of methylphosphonothioic acid (VX), dichlorodiethyl sulfide (mustard), and the primary components of liquid smoke - titanium tetrachloride (FM) and sulfur trioxide/chlorosulfonic acid (FS). 


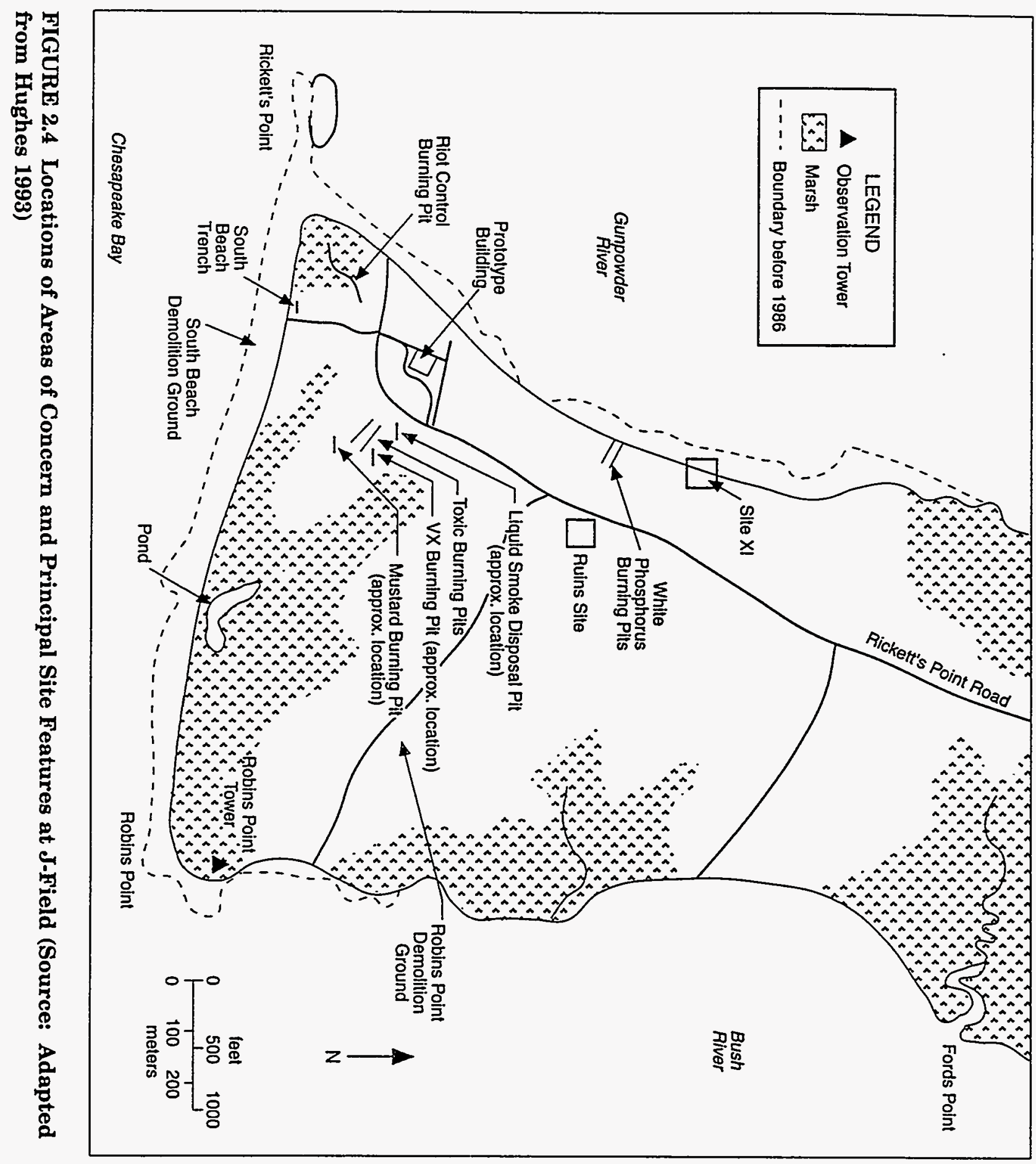


The VX pit and mustard pit are about 100 and $150 \mathrm{ft}$ long, respectively. The liquid smoke disposal pit is fairly small, covering an area of about $24 \mathrm{ft}^{2}$. Liquid smoke was probably disposed of by placing it on the ground and allowing it to vaporize into the atmosphere. HE munitions were also disposed of by detonation in an area along the southeastern edge of the TBP area (Nemeth 1989).

Storage and handling areas have been identified (in aerial photographs) at the upper end of both the VX burning pit and the mustard burning pit. In addition, a square pit approximately $4 \mathrm{ft}$ by $4 \mathrm{ft}$ and $3 \mathrm{ft}$ deep has been identified at the current tree line south of the main burning pits. These storage and handling areas and the pit could be additional sources of contamination in the TBP AOC.

The TBP area is bounded to the northeast by marsh and to the south and southeast by woods and marsh (Nemeth 1989). Because the elevation of the ground surface is highest in the northwestern portion of the TBP area, surface water probably drains toward the southsoutheast into the marsh area. The direction of groundwater flow in the surficial aquifer is probably also toward the marsh. Soils are brownish-yellow silty fine sand at the surface, grading to bluish-gray silty fine sand below a depth of $14 \mathrm{ft}$ (Princeton Aqua Science 1984).

\subsubsection{White Phosphorus Burning Pits AOC}

The WPP AOC is located near the Gunpowder River in the western portion of J-Field (Figure 2.4). The area contains two pits that were used for disposal (by detonation and burning) of white phosphorus (WP), plasticized white phosphorus (PWP), munitions filled with WP, and materials contaminated with WP. After materials were burned and reburned in the pits, debris and soil were pushed out. Some of the materials disposed of at this site probably contained other types of waste in addition to WP. The types and quantities of these other wastes are unknown, although personal interviews indicate that riot control agents may have been disposed of here (Nemeth 1989).

The WPP area has been used as a disposal site since the late 1940s or early 1950s. Aerial photographs show that in 1951, disposal operations were conducted in the southeastern portion of what is currently the open disposal area. The two existing pits were constructed sometime between 1951 and 1957 (Nemeth 1989).

During the late 1950s, the pits were extended to the Gunpowder River. Pushout from the pits was pushed into the river. In 1986, a ditch was excavated to drain water from the pits. The ditch from the northern pit extends north toward a bermed depression that was constructed to hold the water. The ditch associated with the southern pit ends at what is assumed to be a pushout area. During wet weather, water collects in the pits and the bermed depression, even though surface runoff does not enter the pits (Nemeth 1989; Sonntag 1991). As previously noted, the WPP is considered an active emergency disposal facility. As a result, the existing pits and areas potentially affected by emergency disposal operations have been excluded from this ERA and are deferred pending the relocation of emergency disposal operations. However, aerial photograph interpretation indicates that two 
suspect burning areas may have existed northwest and southwest of the WPP and that a storage area may have existed southeast of the WPP. These areas could represent sources of contamination and are not likely affected by current operations. As a result, these areas will be addressed in this ERA work plan.

Surface water drainage from the WPP area flowed west into Gunpowder River. The direction of groundwater flow in the surficial aquifer is also probably toward Gunpowder River to the west (Nemeth 1989). Soils are brownish-yellow silty fine sand at the surface, grading to bluish-grey silty fine sand below a depth of $14 \mathrm{ft}$ (Princeton Aqua Science 1984).

\subsubsection{Riot Control Burning Pit AOC}

The RCP AOC is located in a heavily wooded area in the southwestern portion of J-Field (Figure 2.4). Except for a small area in the northeastern part of the site, the area is overgrown with vegetation. About $30 \mathrm{ft}$ of an access road has been eroded, and the presence of several fallen trees about $10 \mathrm{ft}$ offshore indicates that this area is rapidly being eroded by wave action.

Disposal operations in the pit began in the late 1940s and continued until operations at the site ceased in the early 1970s. The area immediately east of the access road to the South Beach was probably part of the site and may have been used for burning operations during the 1950s. A trench was excavated in the area sometime between 1957 and 1960 and was later extended southwest to the Gunpowder River to provide drainage from the pit. Between 1960 and the early 1970s, the trench was used for burning riot control agents, munitions filled with riot control agents, and material contaminated with these agents (Nemeth 1989). The main agent disposed of was the tear agent o-chlorobenzylidene malononitrile (CS); some chloroacetophenone (CN) was also disposed of there (Sonntag 1991).

Surface water drainage from the RCP area flows toward the southwest into a small marsh area and the Gunpowder River. The direction of groundwater flow in the surficial aquifer is probably toward the marsh and Gunpowder River to the west-southwest. Shallow soils are predominantly clayey sandy silt (Nemeth 1989).

\subsubsection{Prototype Building AOC}

The Prototype Building (PB) AOC is located in the southwestern portion of J-Field, northwest of the TBP area and north of the RCP area (Figure 2.4). The building, constructed during World War II, is an open-sided, three-level reinforced concrete structure. It was originally used for testing the effectiveness of bombs. Since World War II, the PB and the areas to the west and north have been intermittently used for temporary storage of solid waste (Nemeth 1989). Two suspect burning areas have also been identified - one northeast and one west of the PB - on the basis of a review of archival information. 
The area around the PB is fairly flat; surface water drains primarily west toward a marsh area (Nemeth 1989) but may also flow north-northwest toward the Gunpowder River. The direction of groundwater flow in the surficial aquifer is probably toward Chesapeake Bay. The shallow soils are predominantly silty, clayey sand with greater amounts of clay and silt near the surface (Nemeth 1989).

\subsubsection{South Beach Demolition Ground AOC}

The South Beach Demolition Ground (SBDG) AOC was located along the southern beach of J-Field (Figure 2.4). The area was used as a demolition site for HE munitions during the 1960s and 1970s, and possibly during the 1950s (Nemeth 1989). Munitions were detonated either on the surface or under several feet of soil. It is reported that remnants of munitions detonated in this area are currently visible about $100 \mathrm{ft}$ offshore during low tide. At high tide, most of the demolition ground area is 1-2 $\mathrm{ft}$ below water. A few demolition craters, which are assumedly remnants of the SBDG operations, are visible just inland from the shoreline and east of the end of Rickett's Point Road.

Surface water from the remnants of the SBDG most likely drains south toward Chesapeake Bay. The direction of groundwater flow in the surficial aquifer is probably toward the bay as well. The nature of the shallow soils in the SBDG is undocumented; however, they are most likely composed of clayey sandy silt, similar to the South Beach Trench (SBT) area.

\subsubsection{South Beach Trench AOC}

The SBT AOC is located near the southern beach of J-Field, southeast of the RCP area (Figure 2.4). The trench, about $75 \mathrm{ft}$ long and $12 \mathrm{ft}$ wide, was excavated between 1957 and 1960. It may have been a borrow pit for nearby demolition activities. Aerial photographs from the 1960s reveal a road leading into and out of the SBT. No information has been found regarding past chemical or hazardous material disposal in this area; however, chemical analyses of soil samples collected from the trench during the Resource Conservation and Recovery Act (RCRA) Facility Assessment (RFA) showed low levels of chlordane and naphthalene (Nemeth 1989).

Surface water drainage from the SBT is primarily west toward a marsh area (Nemeth 1989), but surface water may also flow south toward Chesapeake Bay. Groundwater in the surficial aquifer probably flows toward Chesapeake Bay. Shallow soils are predominantly clayey sandy silt (Nemeth 1989 ).

\subsubsection{Robins Point Demolition Ground AOC}

The Robins Point Demolition Ground (RPDG) AOC is in the eastern portion of J-Field close to the Bush River (Figure 2.4). The site was first used during the late 1970s for the destruction of $\mathrm{HE}$ and $\mathrm{HE}$-filled munitions. The site was also reportedly used during 
the 1980s for destruction of small amounts of sensitive and unstable chemicals by detonation with explosives (Nemeth 1989).

The original site, now inactive and considered an AOC for the purposes of the RI/FS activities, was a small clearing near the edge of the adjacent marsh. In 1985, the clearing was enlarged, and a berm was built on the western edge of the clearing. Later demolition activities occurred in an area west of the berm; the berm prevented surface runoff from entering the marsh (Nemeth 1989). The area west of the berm has remained active and continues to be used for disposal operations.

Before 1985, surface water drainage from the RPDG flowed directly into the adjacent marsh to the east. The berm constructed in 1985 now prevents runoff from directly entering the marsh. However, water that ponds west of the berm seeps through the berm to the inactive portion of the RPDG. Groundwater in the surficial aquifer probably flows to the east toward the marsh. Shallow soils in the RPDG consist predominantly of clayey silt (Nemeth 1989).

\subsubsection{Robins Point Tower Site AOC}

The Robins Point Tower Site (RPTS) AOC is located near Robins Point at the southeastern tip of the Gunpowder Peninsula (Figure 2.4). The wooden observation tower was built between 1957 and 1960. The road connecting Robins Point with Rickett's Point Road has existed since about 1917, when APG became an army installation. However, aerial photographs suggest that the area was not used until the 1950s. The Robins Point area was used for launching and observing rockets (Nemeth 1989).

Around 1959, the Robins Point area may have been used for at least one test burn of wood contaminated with radioactive material (including radium and strontium). According to Nemeth (1989), the test burn was to be conducted in a trench ( $20 \mathrm{ft}$ long, $5 \mathrm{ft}$ wide, and $5 \mathrm{ft}$ deep), with not more than $500 \mathrm{lb}$ of material to be burned in small increments. A 1959 U.S. Army Environmental Hygiene Agency (USAEHA) report recommended that the routine burning of radioactively contaminated materials be conducted in a closed incinerator; correspondence in the USAEHA project file indicates that this recommendation was accepted (Nemeth 1989). The possibility remains, however, that a test burn of radioactively contaminated wood did occur at either the RPDG or the RPTS. Records do not indicate which site was used. However, it is likely that the RPTS was used because the site of the demolition ground was wooded and not yet in use in 1959. In addition, aerial photographs from the 1960s show no roads or open areas at the site of the RPDG.

Surface water from the RPTS probably flows east toward Bush River and south toward the adjacent marsh. Groundwater in the surficial aquifer probably also flows toward Bush River and the marsh. The shallow soils are predominantly sand, with sandy clayey silt near the surface (Nemeth 1989). 


\subsubsection{Other J-Field Sites}

Pursuant to the requests of the Maryland Department of the Environment (MDE), investigative activities have been expanded beyond the eight specified AOCs to include all of $J$-Field. As a result, a protocol was developed to identify other suspect areas, referred to as potential areas of concern (PAOCs), on the basis of a review of archival information and walkover surveys. Although not currently included for ecological investigations, some PAOCs may be added, pending the results of characterization studies, to the ERA for J-Field. These areas are shown in Figure 2.5. The characterization studies proposed for the PAOCs are described in Appendix B of the FSP (Benioff et al. 1995b).

\subsection{PRELIMINARY EVALUATION OF J-FIELD AREAS OF CONCERN}

Several investigations have been conducted at J-Field to characterize contamination from past operations, install monitoring wells, and characterize the estuarine sediments around the peninsula. Table 2.1 provides a chronological summary of these studies. An overview of the results of these studies is presented in the following sections. These sections present data for J-Field that were collected through January 1993.

\subsubsection{Toxic Burning Pits}

\subsubsection{Types of Waste Present}

The TBP were used to dispose of HE-filled munitions, nerve agents, mustard agents, chemical warfare agents (CWAs), decontaminating agents, liquid smoke, chlorinated solvents, and radioactive chemicals. In addition, fuel was used to ignite materials placed in the pits.

\subsubsection{Types of Contaminants Present}

A hydrological assessment of J-Field was carried out in two phases by the USGS. Phase I was conducted from 1987 to 1992 to select locations for establishing monitoring wells at the TBP and WPP areas. It was assumed that the pits and the open burning grounds around them were the primary sources of contamination in the area. The goal of Phase II, conducted in 1992, was to determine the extent of contamination in the area of the TBP, sample the RCP area, and determine if contaminated groundwater was moving into Chesapeake Bay (Hughes 1993). The following subsections discuss the findings relative to the nature and extent of contamination in the TBP area. 


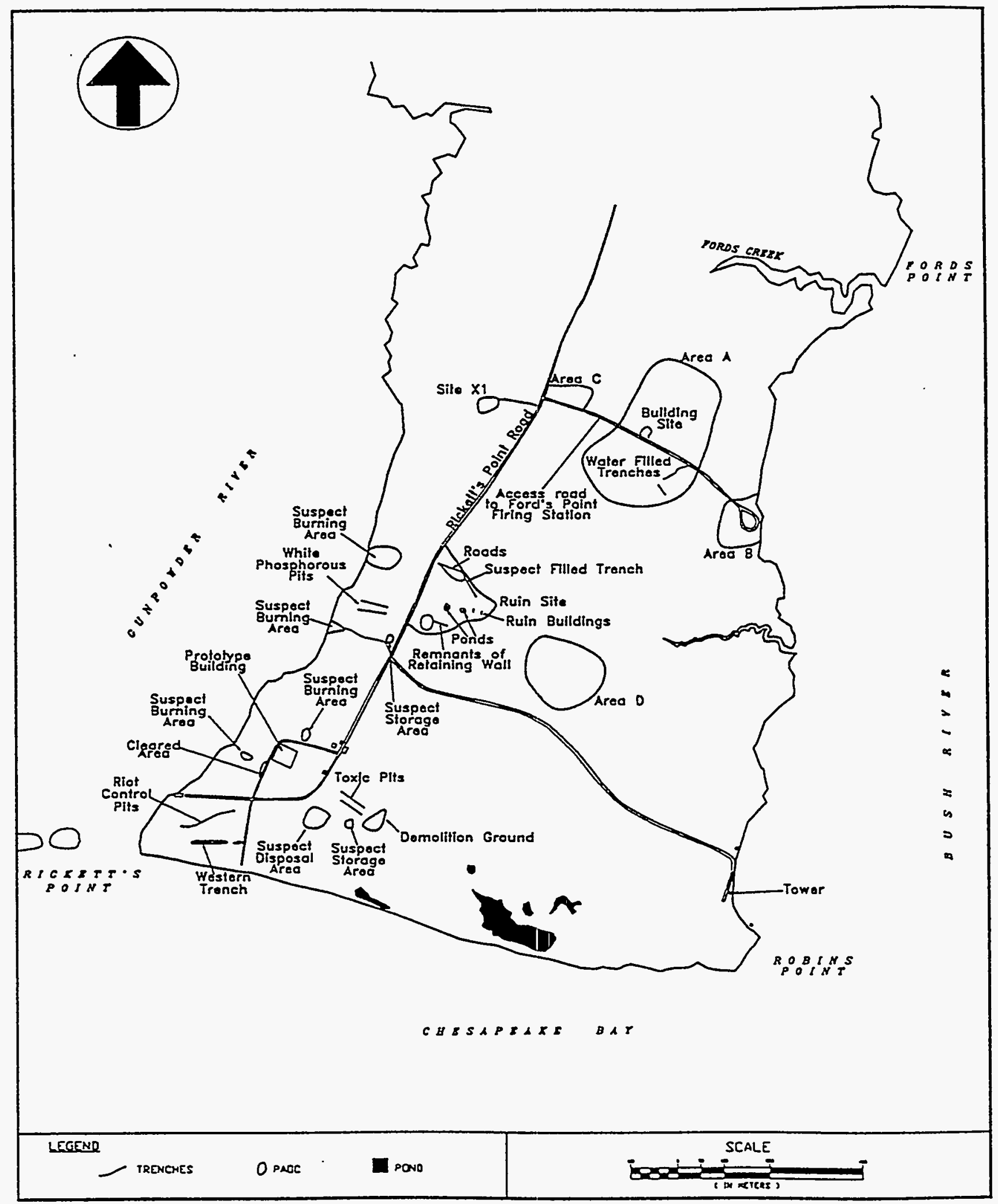

FIGURE 2.5 Locations of PAOCs at J-Field 
TABLE 2.1 Summary of Previous Investigations at J-Field

\begin{tabular}{|c|c|c|c|}
\hline Field Investigation & Investigator & Date & Objective/Activity \\
\hline $\begin{array}{l}\text { Environmental } \\
\text { Contamination Survey }\end{array}$ & USATHAMA $^{\mathrm{a}}$ & $1977-1978$ & $\begin{array}{l}\text { Conducted to determine if contamination from past } \\
\text { operations was migrating off-post. Eleven monitoring wells } \\
\text { (TH1-11) were installed in the surficial aquifer }-10 \text { near the } \\
\text { TBP and WPP and } 1 \text { near the Robins Point Tower. Ground- } \\
\text { water samples were collected and analyzed. }\end{array}$ \\
\hline Munitions Disposal Study & $\begin{array}{l}\text { Princeton Aqua } \\
\text { Science }\end{array}$ & 1983 & $\begin{array}{l}\text { Installed nine monitoring wells (P1-9) in the surficial } \\
\text { aquifer - five near the TBP and four near the WPP. } \\
\text { Composite soil samples were collected during drilling of wells. } \\
\text { Soil samples were also collected from the pits in the TBP and } \\
\text { WPP areas. }\end{array}$ \\
\hline $\begin{array}{l}\text { RCRA Facility } \\
\text { Investigation }\end{array}$ & USAEHA & 1986 & $\begin{array}{l}\text { Sampled groundwater from TH and P series wells. Soil } \\
\text { samples also collected in and around the pits in the TBP, } \\
\text { WPP, and RCP areas and near the Prototype Building. A } \\
\text { field radiation survey was also performed. }\end{array}$ \\
\hline $\begin{array}{l}\text { Hydrological Assessment, } \\
\text { Phase I }\end{array}$ & USGS & 1987-1992 & $\begin{array}{l}\text { Drilled exploratory boreholes, collected soil samples, and ran } \\
\text { geophysical logs. Installed } 12 \text { well clusters (JF1-12), each } \\
\text { consisting of } 3 \text { wells screened in the upper portions of the } \\
\text { confined aquifer, the confining unit, and surficial aquifer. } \\
\text { Wells were sampled on a monthly (1987) and quarterly } \\
\text { basis (1989-1992); water-level measurements also taken. } \\
\text { Conducted slug tests. Currently using MODFLOW model to } \\
\text { simulate contaminant pathways in groundwater. A total of } \\
21 \text { surface samples also collected from Gunpowder River and } \\
\text { Chesapeake Bay. Soil and soil-gas samples collected in TBP } \\
\text { and WPP areas. }\end{array}$ \\
\hline
\end{tabular}




\section{TABLE 2.1 (Cont.)}

\begin{tabular}{|c|c|c|c|}
\hline Field Investigation & Investigator & Date & Objective/Activity \\
\hline $\begin{array}{l}\text { Characterization and } \\
\text { Interim Remediation }\end{array}$ & $\begin{array}{l}\text { Roy F. Weston, } \\
\text { Inc. }\end{array}$ & 1992 & $\begin{array}{l}\text { Activities included topographic survey of J-Field area; survey } \\
\text { of UXO }{ }^{\mathrm{b}} \text { in each burning pit and along shoreline of WPP and } \\
\text { RCP; construction of access roads; placement of riprap and } \\
\text { gabion structures along WPP and RCP shoreline; removal } \\
\text { and staging of surface material and debris from burning pit } \\
\text { areas; sampling and staging drums from the PB; sampling } \\
\text { and analysis of soil from the pits and pushout areas; } \\
\text { installation of flood control berms in the pit areas, where } \\
\text { needed; and collection of surface and subsurface soil samples. }\end{array}$ \\
\hline $\begin{array}{l}\text { Hydrological Assessment- } \\
\text { Phase II }\end{array}$ & USGS & 1992 & $\begin{array}{l}\text { Continued sampling of groundwater, measuring water levels } \\
\text { in all monitoring wells, and slug testing. Four new wells } \\
\text { installed. Collected surface water samples from marsh areas } \\
\text { and estuaries surrounding J-Field, based on thermal imagery } \\
\text { studies conducted by the USGS. }\end{array}$ \\
\hline Sediment Sampling Study & EPA & 1992 & $\begin{array}{l}\text { Conducted a study to characterize the estuarine sediments } \\
\text { around the Gunpowder Neck Peninsula. }\end{array}$ \\
\hline
\end{tabular}

a USATHAMA = U.S. Army Toxic and Hazardous Materials Agency.

b $\mathrm{UXO}=$ unexploded ordnance. 


\section{Soil Gas}

During Phase I of the hydrological assessment, the USGS sampled 37 locations around the TBP for soil-gas concentrations of trichloroethylene (TRCLE), tetrachloroethylene (TCLEE), alkanes, combined hydrocarbons, and simple aromatics. The relative contours for all contaminants except the alkanes show a broad band of contamination that extends across the eastern end of the pits from the marsh on the north to the marsh on the south (Figure 2.6). The alkanes appear to be limited to the area south of the TBP, and the data suggest a plume of contamination moving into the marsh at the southern edge (Figure 2.7) (Hughes 1993).

Additional soil-gas samples were collected during Phase II from wooded and marshy areas north and south of the TBP and from 15 locations along Chesapeake Bay. Samples were analyzed for combined dichloroethylenes (DCEs) and trichloroethanes (TCEs), combined TRCLEs and TCLEEs, phthalates, and heavy aromatic hydrocarbons (Hughes 1993).

Relative values and contours for concentrations of combined DCE and TCE and of combined TRCLE and TCLEE show a similar distribution, with elevated contamination to the southeast of the TBP. Figure 2.8 shows contours for combined TRCLE and TCLEE. The DCE plus TCE contamination south of the pits is somewhat more extensive, with elevated values extending to the shore of Chesapeake Bay. The concentration contours, when combined with contours from Phase I analyses, suggest that plumes of contaminated groundwater are moving downgradient under the marshes both on the northern and southern sides of the TBP. This hypothesis is supported by the relative contours for heavy aromatics (Figure 2.9), which show locations with more extensive contamination, including along the shore. The data also suggest that contaminated groundwater may be moving beneath, and possibly discharging into, the bay, or that contaminated surface water from the marshes may be moving into shore sediments (Hughes 1993).

\section{Soil}

In 1983, soil samples were collected during the installation of monitoring wells at the TBP. Four composite samples were collected at depth intervals of $5 \mathrm{ft}$. The samples were analyzed for metals, cyanide, phenols, total phosphorus, volatile organic compounds (VOCs), pesticides, polychlorinated biphenyls (PCBs), and herbicides. Some of the results are listed in Table 2.2. The data showed elevated concentrations of lead, zinc, nitrate, and petroleum hydrocarbons in each of the samples. It should be noted that the background samples also contained somewhat elevated concentrations of petroleum hydrocarbons.

During the 1986 RFA (Nemeth 1989), surface soil samples were collected from 20 locations in the TBP and the debris pushout area (Figure 2.10). All of the samples were analyzed for metals, extractable metals, and explosives-related compounds. The results, as summarized in Table 2.3, show that the surface soil in and around the TBP contain elevated 


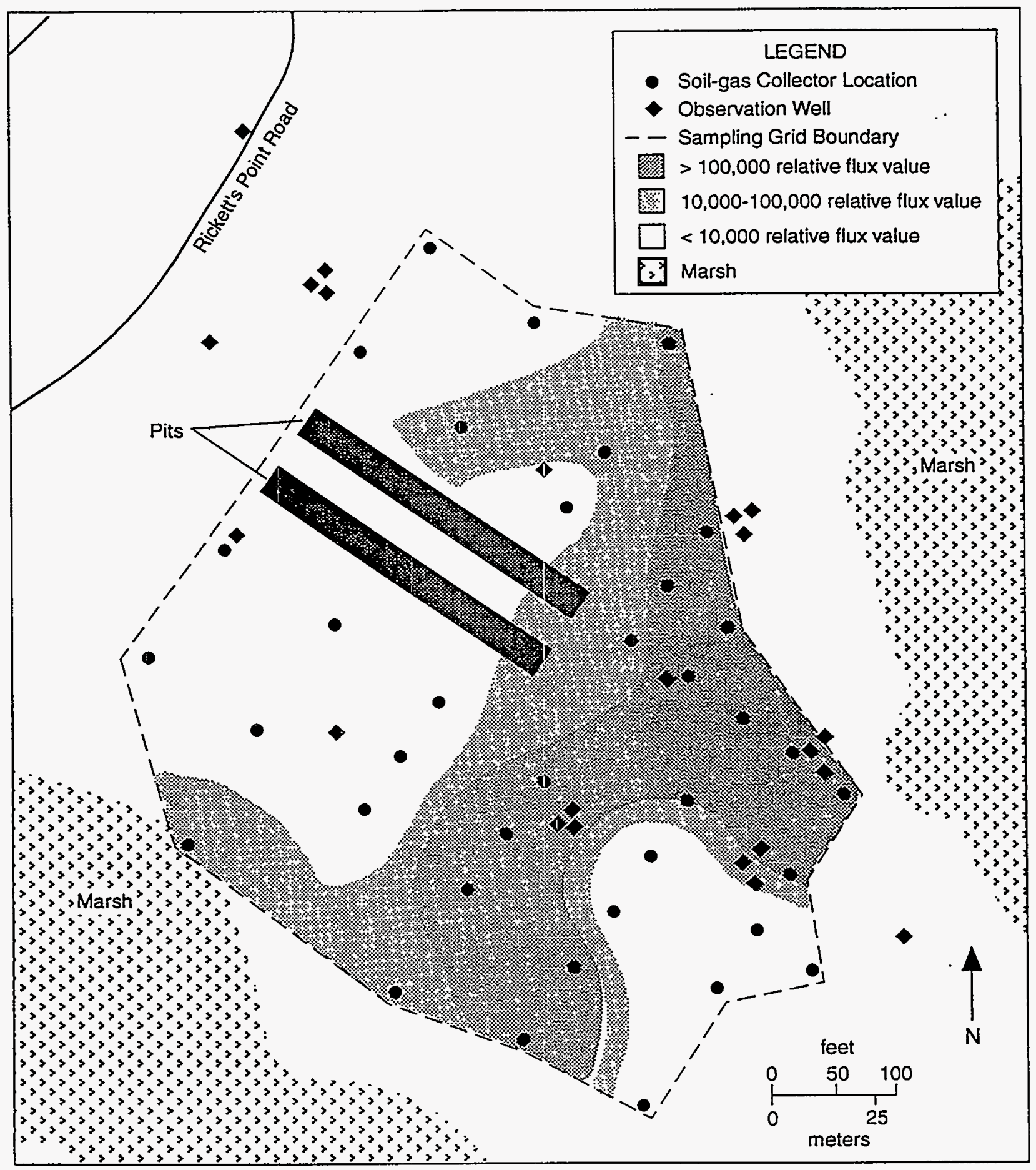

FIGURE 2.6 Relative Contours for all Soil-Gas Parameters (except alkanes) at the Toxic Burning Pits Area (Source: Adapted from Hughes 1993) 


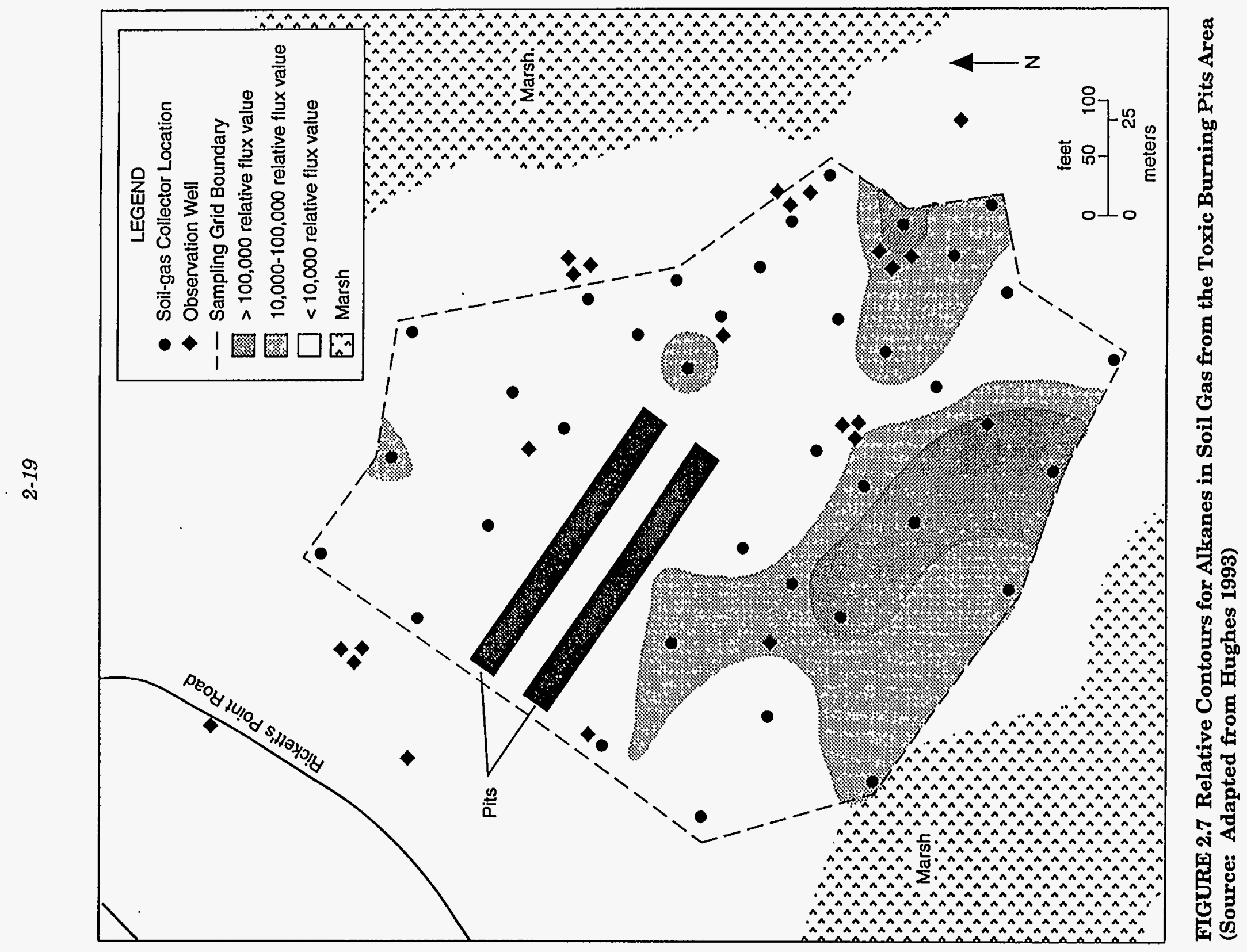




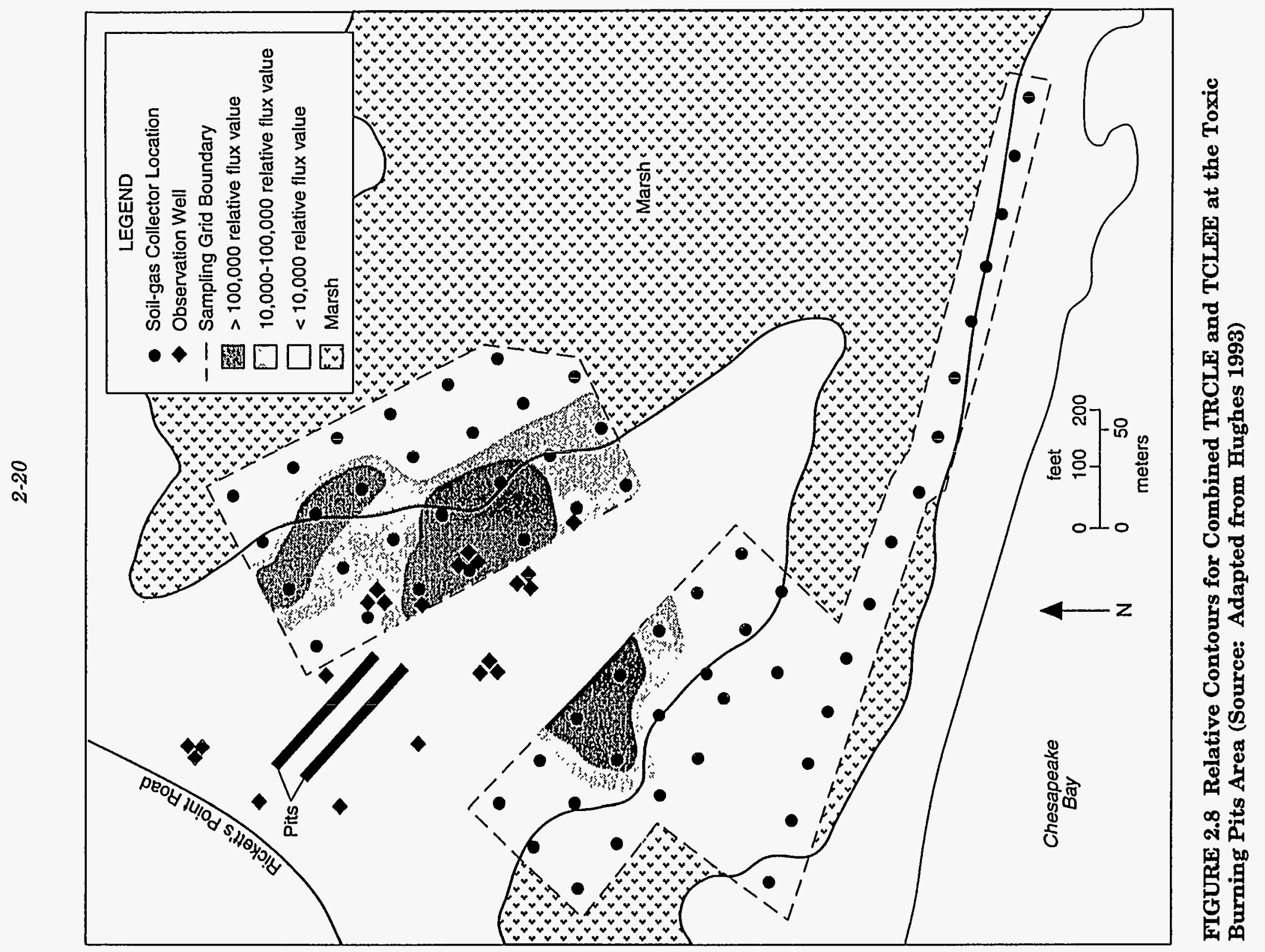




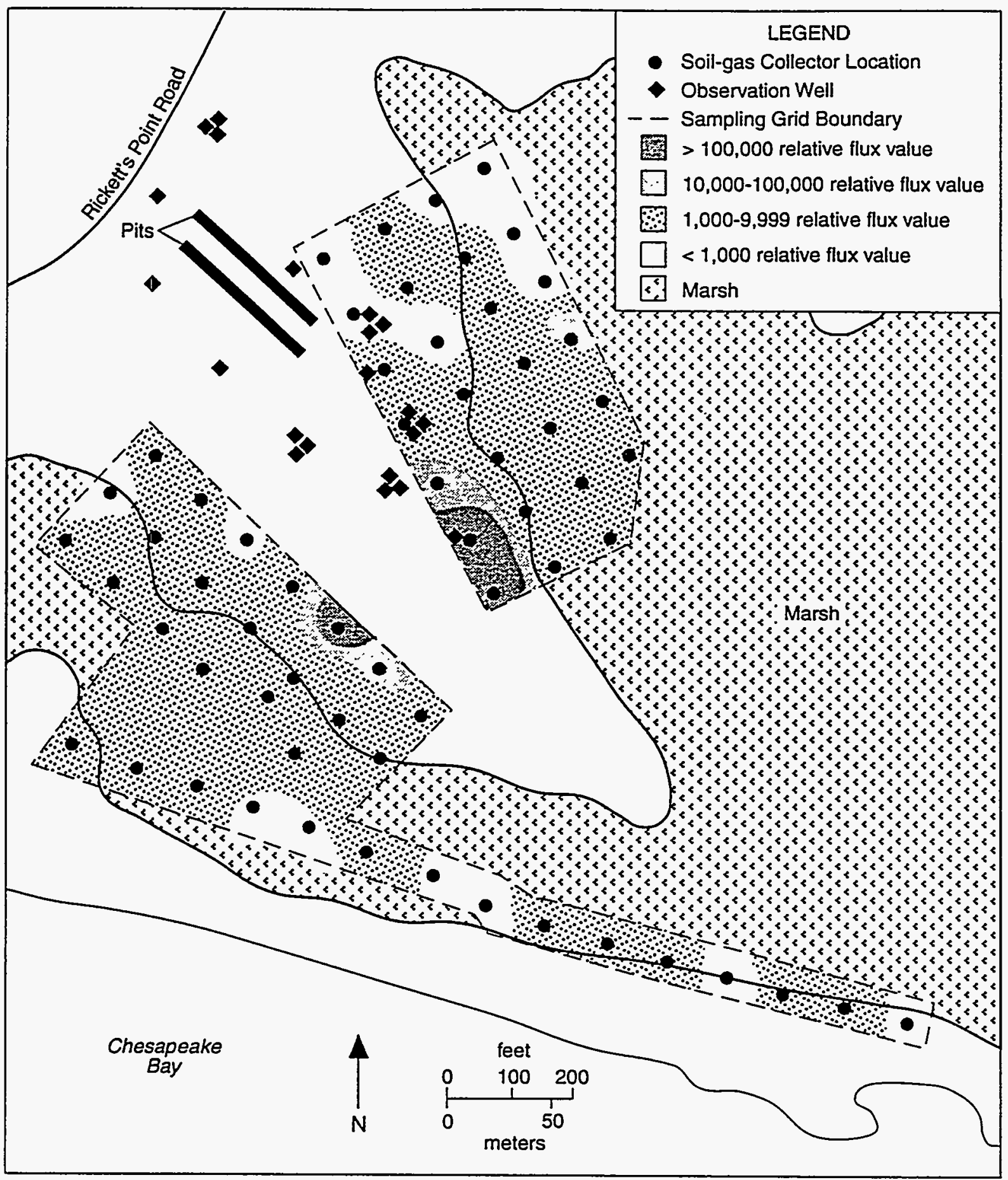

FIGURE 2.9 Relative Contours for Heavy Aromatics in Soil Gas from the Toxic Burning Pits Area (Source: Adapted from Hughes 1993) 
TABLE 2.2 Analytical Results for Analysis of Soil Samples from the Toxic Burning Pits AOC Main Burning Pits, January 1983

\begin{tabular}{|c|c|c|c|}
\hline \multirow[b]{2}{*}{ Parameter $^{a}$} & \multicolumn{3}{|c|}{$\begin{array}{l}\text { Parameter Concentrations } \\
\text { (mg/kg except as noted) }\end{array}$} \\
\hline & $\begin{array}{l}\text { Back- } \\
\text { ground }^{b}\end{array}$ & Pit $1^{c}$ & Pit $2^{c}$ \\
\hline Arsenic & $<0.481$ & 3.56 & $<0.53$ \\
\hline Barium & 110 & 247 & 257 \\
\hline Cadmium & 0.84 & 4.46 & 2.19 \\
\hline Chromium & 74.70 & 413 & 192 \\
\hline Iron & 6,000 & 18,900 & 17,000 \\
\hline Lead & 76.90 & 717 & 281 \\
\hline Manganese & 153 & 169 & 206 \\
\hline Mercury & 0.034 & 0.080 & 0.008 \\
\hline Potassium & 857 & 1,450 & 1,650 \\
\hline Zinc & 250 & 1,510 & 810 \\
\hline pH (standard units) & 6.30 & 8.50 & 8.80 \\
\hline Nitrate & 295 & 316 & 249 \\
\hline Total phosphorus & 9.00 & $<0.50$ & $<0.25$ \\
\hline Cyanide & $<0.50$ & $<0.50$ & $<0.50$ \\
\hline $\begin{array}{l}\text { Petroleum } \\
\text { hydrocarbons }\end{array}$ & 113 & 800 & 850 \\
\hline Phenols & 0.37 & $<0.13$ & 0.31 \\
\hline Toluene ( $\mu \mathrm{g} / \mathrm{kg})$ & $<20.00$ & 32.00 & 28.00 \\
\hline Ethylbenzene $(\mu \mathrm{g} / \mathrm{kg})$ & 20.00 & $<20.00$ & $<20.00$ \\
\hline
\end{tabular}

a Table lists all parameters detected at least once.

b Locations of background samples not given.

c Based on available information, it is inferred that Pit 1 is the northern main burning pit and Pit 2 is the southern main burning pit.

Source: Adapted from Princeton Aqua Science (1984). 


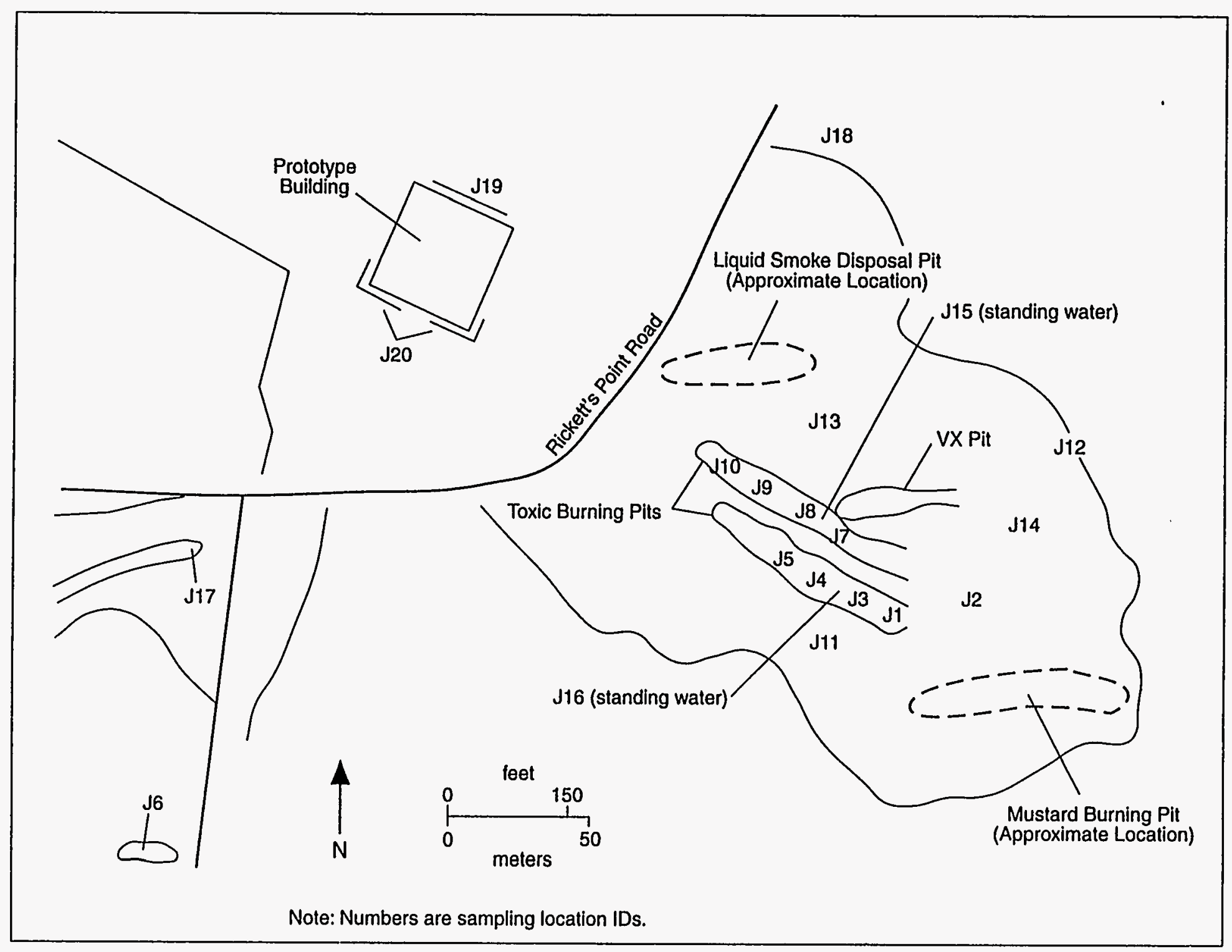

FIGURE 2.10 Locations in the Toxic Burning Pits Area where Surface Soil and Surface Water Samples Were Collected during the 1986 RCRA Facility Assessment (Source: Adapted from Nemeth 1989) 
TABLE 2.3 Analytical Results for Analysis of Soil Samples J1-J20 from the Toxic Burning Pits, 1986

\begin{tabular}{|c|c|c|c|c|c|c|c|c|c|}
\hline Parameter $^{\mathbf{a}}$ & J1 & $\mathrm{J}^{\mathrm{b}}$ & J3 & $\mathrm{J} 4$ & J5 & J6 & $\mathrm{J} 7$ & J8 & J9 \\
\hline \multicolumn{10}{|c|}{ Total Metals (mg/kg) } \\
\hline Arsenic & 54.8 & 25.2 & 21.5 & 40.5 & 18.5 & 9.7 & 47.3 & 25.7 & 43.9 \\
\hline Barium & 592 & 277 & 313 & 90.5 & 134 & $<60$ & 488 & 172 & 296 \\
\hline Cadmium & 8.13 & 4.57 & 2.52 & 4.88 & 1.58 & 2.20 & 17.3 & 8.64 & 6.10 \\
\hline Chromium & 75.5 & 54.4 & 45.9 & 95.9 & 70.8 & 10.7 & 73.3 & 76.0 & 53.3 \\
\hline Lead & 472 & 548 & 378 & 85.3 & 60.3 & 38.5 & 2,998 & 720 & 1,369 \\
\hline Mercury & 0.78 & 0.87 & 0.46 & 0.15 & 0.22 & 0.17 & 2.16 & 10.8 & 7.29 \\
\hline Silver & 14.0 & $<5.0$ & $<5.0$ & 12.1 & $<5.0$ & $<5.00$ & 15.2 & 7.01 & $<5.0$ \\
\hline \multicolumn{10}{|c|}{ Extractable Metals (mg/L) } \\
\hline Cadmium & $<0.10$ & $<0.10$ & $<0.10$ & $<0.10$ & $<0.10$ & $<0.10$ & 0.228 & $<0.10$ & $<0.10$ \\
\hline Lead & $<0.50$ & $<0.50$ & $<0.50$ & $<0.50$ & $<0.50$ & $<0.50$ & 5.23 & $<0.50$ & $<0.50$ \\
\hline \multirow[t]{2}{*}{ Silver } & $<0.50$ & $<0.50$ & $<0.50$ & $<0.50$ & $<0.50$ & $<0.50$ & $<0.50$ & $<0.50$ & $<0.50$ \\
\hline & $\mathrm{J} 10$ & J11 & $\mathrm{J} 12$ & J13 & J14 & J17 & J18 & J19 & J20 \\
\hline \multicolumn{10}{|c|}{ Total Metals (mg/kg) } \\
\hline Arsenic & 32.2 & 12.6 & 24.1 & 8.26 & 28.7 & 15.9 & 6.5 & 9.74 & 12.3 \\
\hline Barium & 208 & 101 & 855 & 107 & 256 & $<60$ & 81.4 & $<60$ & $<60$ \\
\hline Cadmium & 4.75 & 0.27 & 3.57 & 1.01 & 1.47 & 5.02 & $<0.20$ & 5.38 & 16.6 \\
\hline Chromium & 58.0 & 12.1 & 80.1 & 19.2 & 30.4 & 63.9 & 6.65 & 15.4 & 13.5 \\
\hline Lead & 4,101 & 15.8 & 26,040 & 41.8 & 1,522 & 203 & 12.1 & 140 & 1,622 \\
\hline Mercury & 6.10 & 0.11 & 0.77 & 0.11 & 0.59 & 0.20 & $<0.10$ & 0.28 & 3.40 \\
\hline Silver & $<5.0$ & $<5.0$ & $<5.0$ & $<5.0$ & $<5.0$ & 8.64 & $<5.0$ & $<5.0$ & $<5.0$ \\
\hline \multicolumn{10}{|c|}{ Extractable Metals (mg/L) } \\
\hline Cadmium & $<0.10$ & $<0.10$ & $<0.10$ & $<0.10$ & $<0.10$ & $<0.10$ & $<0.10$ & $<0.10$ & 0.112 \\
\hline Lead & $<0.50$ & $<0.50$ & 31.2 & $<0.50$ & $<0.50$ & $<0.50$ & $<0.50$ & $<0.50$ & $<0.50$ \\
\hline Silver & $<0.50$ & $<0.50$ & $<0.50$ & $<0.50$ & 0.154 & $<0.50$ & $<0.50$ & $<0.50$ & $<0.50$ \\
\hline
\end{tabular}

a Includes parameters that were detected in at least one soil sample.

b VOCs were measured in sample $\mathrm{J} 2$ only; $1,000 \mu \mathrm{g} / \mathrm{kg}$ TRCLE and traces of other VOCs were found.

Source: Nemeth (1989). 
levels of metals, especially lead (up to $2.6 \%$ in the pushout area [location 12]); mercury (up to $10.8 \mathrm{mg} / \mathrm{kg}$ in one of the pits [location 8]); and cadmium (16.6 mg/kg at location 20). Samples from locations 7 and 12 exceeded the RCRA extraction procedure (EP) limit of $5.0 \mathrm{mg} / \mathrm{L}$ for lead (40 CFR 261).

Composite samples from locations 1 and 2 contained $13,000 \mu \mathrm{g} / \mathrm{kg}$ heptachlor epoxide and lower concentrations of other pesticides. Aroclor 1248 (a PCB) was detected at a concentration of $230,000 \mu \mathrm{g} / \mathrm{kg}$. Composites from locations 3 through 5, 7 through 10, 19, and 20 (near the $\mathrm{PB}$ ) also contained pesticides $-1,000 \mu \mathrm{gg} / \mathrm{kg}$ each dichlorodiphenyldichloroethane (DDD), dichlorodiphenyldichloroethylene (DDE), and dichlorodiphenyltrichloroethane (DDT) (in locations 19 and 20 only); and $3,700 \mu \mathrm{g} / \mathrm{kg}$ PCBs (locations 3 through 5 only). Hughes (1993) states that detection of pesticides in samples containing PCBs may represent false positives. PCBs reportedly were used as heat-transfer fluids at the Edgewood Area and disposed of at J-Field (Nemeth 1989). Trace concentrations of organic compounds were also detected in samples: TRCLE (at 1,000 $\mathrm{gg} / \mathrm{kg}$ ) and traces of other VOCs in the sample from location 2 , the only sample analyzed for VOCs.

Soil samples were collected by the USGS from depths of approximately $1 \mathrm{ft}$ below land surface at 36 sites in J-Field, including the TBP area (Figure 2.11). The samples were analyzed for indicator parameters, metals, VOCs, semivolatile compounds, and explosives (Hughes 1992). The results of these analyses, except for explosives, are presented in Table 2.4. Soil samples showed some metals contamination, especially at locations 39 and 30, north of the Mustard Pit. Traces of organic compounds were also detected in some samples.

Soil samples were also collected in the TBP area by Weston in October 1992 (Figure 2.12). The samples were collected at depths of 2, 4, and $6 \mathrm{ft}$ in the pits; and at depths of $3 \mathrm{in}$. and $1 \mathrm{ft}$ in the marshes and pushout areas. Tables 2.5 and 2.6 summarize the analytic results for parameters detected in some of these samples.

The highest concentrations of organic compounds were found in the area of the Mustard Pit: 1,1,2,2-tetrachloroethane (TCLEA), up to 3,270,000 $\mu \mathrm{g} / \mathrm{kg}$ at $6 \mathrm{ft}$; 1,1,2-trichloroethane (112TCE), up to $8,500 \mu \mathrm{g} / \mathrm{kg}$ at $6 \mathrm{ft}$; TCLEE, up to $25,700 \mu \mathrm{g} / \mathrm{kg}$ at $6 \mathrm{ft}$; and TRCLE, up to $263,000 \mathrm{\mu g} / \mathrm{kg}$ at $6 \mathrm{ft}$. Organic compounds, including TCLEA, 112TCE, acetone, methylene chloride, and TRCLE, were detected in the main burning pits (see Table 2.6). High levels of PCBs were detected in the southern main pit (up to $143,000 \mu \mathrm{g} / \mathrm{kg}$ at $2 \mathrm{ft}$ ), the mustard pit (up to $178 \mu \mathrm{g} / \mathrm{kg}$ at $6 \mathrm{ft}$ ), the southern marsh (up to $3,200 \mu \mathrm{gg} / \mathrm{kg}$ at $1 \mathrm{ft}$ ), and the pushout area northwest of the main pits (up to $3,800 \mu \mathrm{g} / \mathrm{kg}$ at $1 \mathrm{ft}$ ). The highest concentrations of lead were found in the southern main pit ( $340 \mathrm{mg} / \mathrm{kg}$ at $2 \mathrm{ft}$ ), the mustard pit (121 mg/kg at $6 \mathrm{ft})$, the southern marsh - $(542 \mathrm{mg} / \mathrm{kg}$ at $1 \mathrm{ft})$, the marsh east of the main pits $(79,800 \mathrm{mg} / \mathrm{kg}$ at $3 \mathrm{in}$.$) , and the pushout area northwest of the main pits$ $(1,180 \mathrm{mg} / \mathrm{kg}$ at $3 \mathrm{in}$.$) .$ 


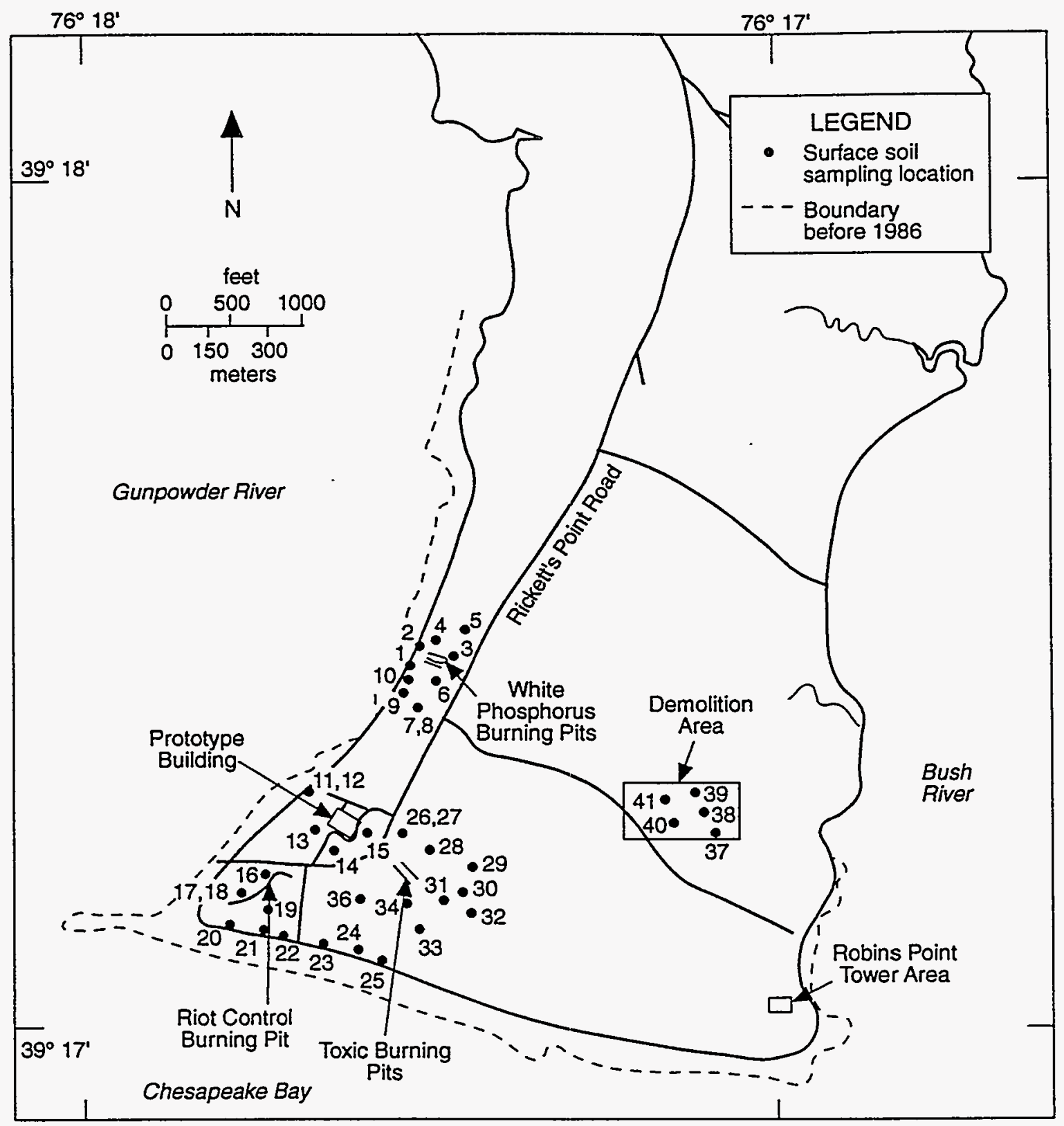

FIGURE 2.11 Locations where Soil Samples Were Collected by the USGS in 1991 (Source: Adapted from Hughes 1992) 
TABLE 2.4 Analytical Results for Analysis of Soil Samples from the Toxic Burning Pits Area, April 1991

\begin{tabular}{|c|c|c|c|c|c|c|c|c|c|c|c|c|c|}
\hline \multirow[b]{2}{*}{ Parameter } & \multicolumn{13}{|c|}{ Concentration by Soil Sample Location ${ }^{\text {b }}$} \\
\hline & 23 & 24 & 25 & 26 & 27 & 28 & 29 & 30 & 31 & 32 & 33 & 34 & 36 \\
\hline \multicolumn{14}{|l|}{ Metals (mg/kg) } \\
\hline Arsenic & 3.7 & 3.2 & ND & 4.5 & 4.2 & 7.8 & 49 & 21 & 2.6 & 3.3 & 3.5 & 6.6 & 3.2 \\
\hline Cadmium & ND & ND & $\mathrm{ND}$ & ND & ND & 2.4 & 16 & $\mathrm{ND}$ & ND & ND & $\mathrm{ND}$ & ND & ND \\
\hline Chromium & 14 & 11 & 6.6 & 16 & 15 & 37 & 121 & 46 & 12 & 13 & 13 & 17 & 17 \\
\hline Copper & 21 & 50 & 10 & 22 & 19 & 233 & 786 & 48 & 4.2 & 11 & 15 & 40 & 17 \\
\hline Lead & 17 & 40 & 14 & 41 & 38 & 662 & 87,100 & 952 & 15 & 17 & 29 & 42 & 19 \\
\hline Antimony & ND & ND & ND & ND & ND & ND & 1,120 & $\mathrm{ND}$ & ND & $\mathrm{ND}$ & ND & ND & ND \\
\hline Zinc & ND & $\mathrm{ND}$ & 20 & 96 & 157 & ND & 7,960 & ND & 25 & ND & ND & $\mathrm{ND}$ & ND \\
\hline \multicolumn{14}{|c|}{ Volatile Organic Compounds ( $\mu \mathrm{g} / \mathrm{kg}$ ) } \\
\hline Acetone & 5.89 & 13.9 & 6.73 & 15.8 & 6.75 & 9.80 & 15.7 & 4.88 & 2.24 & ND & 21.0 & ND & ND \\
\hline cis-1,2-Dichloroethylene & NA & NA & NA & NA & NA & 2.4 & NA & 2.40 & NA & NA & NA & NA & NA \\
\hline Trichloroethylene & ND & ND & ND & ND & ND & 1.12 & ND & ND & ND & ND & ND & ND & ND \\
\hline \multicolumn{14}{|c|}{ Semivolatile Organic Compounds ( $\mu \mathrm{g} / \mathrm{kg}$ ) } \\
\hline Butylbenzl phthalate & $\mathrm{ND}$ & 598 & ND & ND & 720 & ND & 580 & ND & ND & ND & ND & ND & $\mathrm{ND}$ \\
\hline Benzoic acid & 353 & 7,000 & 1,500 & $\mathrm{ND}$ & $\mathrm{ND}$ & $\mathrm{ND}$ & 420 & 420 & ND & $\mathrm{ND}$ & 2,100 & $\mathrm{ND}$ & $\mathrm{ND}$ \\
\hline \multicolumn{14}{|l|}{ Other (mg/kg) } \\
\hline Total Kjeldahl nitrogen & 1,040 & 2,340 & 695 & 249 & 247 & 637 & 605 & 488 & 627 & 1,030 & 1,730 & 639 & 552 \\
\hline Total organic carbon & 958 & 2,590 & 1,630 & 1,190 & 1,720 & 1,690 & 1,630 & 1,190 & 1,390 & 871 & 1,810 & 752 & 1,010 \\
\hline Total organic halogen & ND & ND & 157 & 20 & 48 & 37 & 34 & ND & ND & ND & ND & ND & ND \\
\hline
\end{tabular}




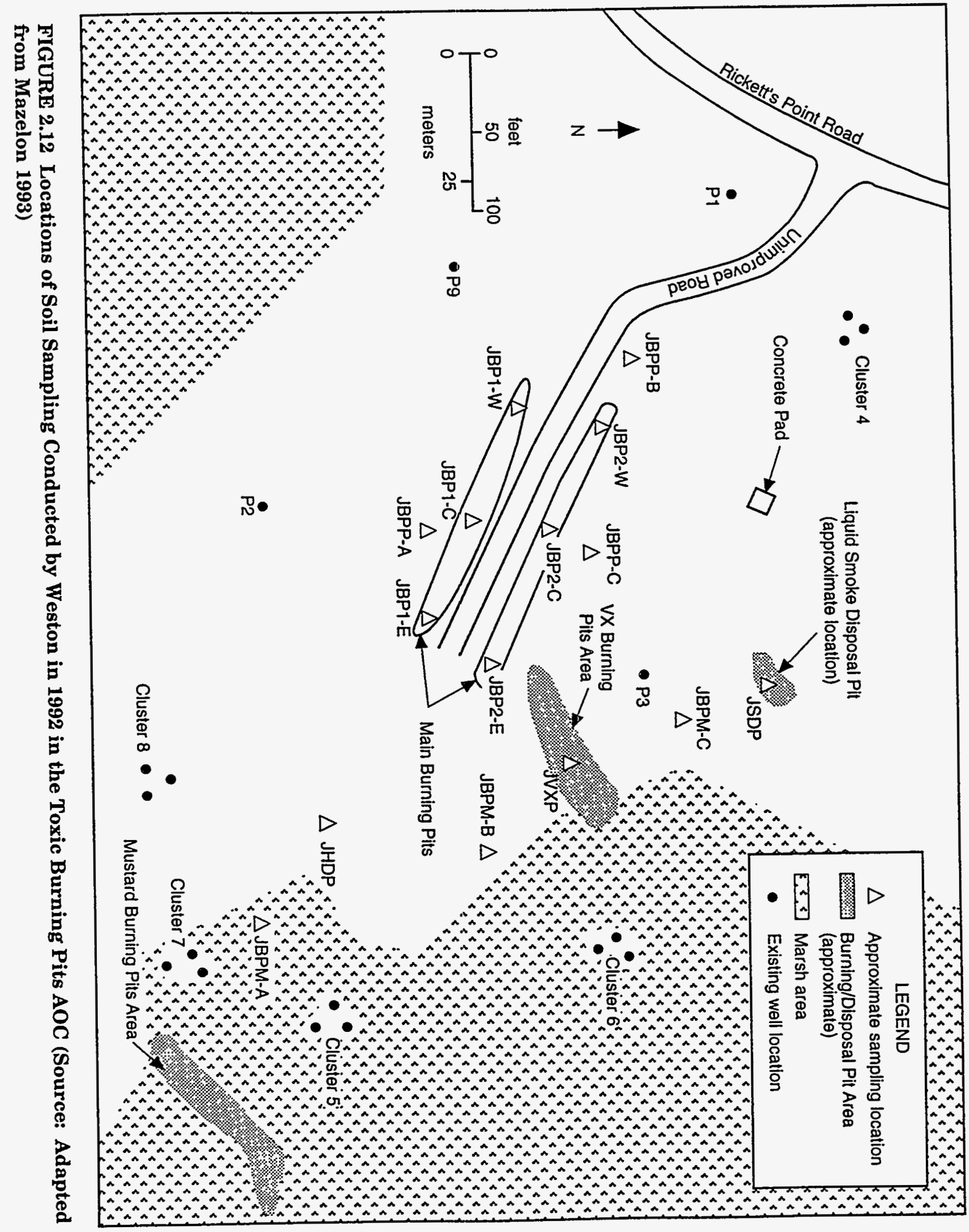


TABLE 2.5 Analytical Results for Target Compound List Analytes in Selected Soil Samples from the Toxic Burning Pits, 1992 ${ }^{\mathrm{a}}$

\begin{tabular}{|c|c|c|c|c|c|c|c|c|}
\hline \multirow[b]{2}{*}{ TCL $^{\mathrm{b}}$ Analyte } & \multicolumn{8}{|c|}{ Concentrations ( $\mu \mathrm{g} / \mathrm{kg}$ ) by Soil Sample Location } \\
\hline & $\mathrm{JBP} 1-\mathrm{E}\left(2^{\prime}\right)^{\mathrm{c}}$ & JBP1-E(4) & JBP2-E(2) & JBP2-E(4') & $\operatorname{JXXP}\left(4^{\prime}\right)$ & $\operatorname{JVXP}\left(6^{\prime}\right)$ & $\operatorname{JSDP}\left(4^{\prime}\right)$ & $\operatorname{JSDP}\left(6^{\prime}\right)$ \\
\hline \multicolumn{9}{|l|}{ Volatile Organic Compounds } \\
\hline 1,1,2,2-Tetrachloroethane & 6.74 & $\mathrm{ND}^{\mathrm{d}}$ & ND & ND & 167 & 39 & 15,200 & 25.6 \\
\hline 1,1,2-Trichloroethane & ND & ND & ND & ND & ND & ND & 80.5 & ND \\
\hline 1,1-Dichloroethane & ND & ND & ND & ND & ND & ND & ND & ND \\
\hline 1,1-Dichloroethylene & ND & ND & ND & ND & ND & ND & ND & ND \\
\hline 1,2-Dichloroethane & ND & ND & ND & ND & ND & ND & ND & ND \\
\hline Acetone & 16.4 & 33 & 44.7 & 116 & ND & ND & 344 & ND \\
\hline Benzene & ND & ND & ND & ND & ND & ND & ND & ND \\
\hline Carbon tetrachloride & ND & ND & ND & ND & ND & ND & ND & ND \\
\hline Chloroform & ND & ND & ND & ND & ND & ND & $\mathrm{ND}$ & $\mathrm{ND}$ \\
\hline Methylene chloride & ND & 6.23 & ND & 6.30 & 7.03 & 8.25 & 44.0 & 12.4 \\
\hline Tetrachloroethylene & ND & $\mathrm{ND}$ & ND & ND & ND & ND & ND & ND \\
\hline Toluene & ND & ND & ND & ND & $\mathrm{ND}$ & ND & ND & $\mathrm{ND}$ \\
\hline trans-1,2-Dichloroethylene & ND & ND & ND & ND & ND & ND & 78.0 & ND \\
\hline Trichloroethylene & 28.1 & ND & ND & ND & ND & 15.8 & 345 & ND \\
\hline Vinyl chloride & ND & ND & ND & ND & ND & ND & ND & ND \\
\hline Xylenes & 12.4 & ND & $\mathrm{ND}$ & ND & ND & $\mathrm{ND}$ & $\mathrm{ND}$ & ND \\
\hline \multicolumn{9}{|c|}{ Semivolatile Organic Compounds } \\
\hline 2-Methylnaphthalene & 471 & ND & ND & ND & ND & ND & ND & ND \\
\hline Hexachloroethane & ND & ND & ND & ND & ND & ND & ND & ND \\
\hline Pyrene & 580 & ND & ND & ND & ND & ND & ND & ND \\
\hline \multicolumn{9}{|l|}{ PCBs } \\
\hline Aroclor 1248 & 143,000 & 1,180 & ND & ND & ND & ND & ND & ND \\
\hline Aroclor 1254 & ND & ND & 224 & ND & ND & ND & ND & ND \\
\hline
\end{tabular}


TABLE 2.5 (Cont.)

\begin{tabular}{|c|c|c|c|c|c|c|}
\hline \multirow[b]{2}{*}{ TCL Analyte } & \multicolumn{6}{|c|}{ Concentration $(\mu \mathrm{g} / \mathrm{kg})$ by Soil Sample Location } \\
\hline & $\operatorname{JHDP}\left(4^{\prime}\right)$ & $\mathrm{JHDP}\left(6^{\prime}\right)$ & JBPM-A(3") & JBPM-A(1') & JBPM-B(3") & JBPM-B(1') \\
\hline \multicolumn{7}{|l|}{ Volatile Organic Compounds } \\
\hline 1,1,2,2-Tetrachloroethane & 289,000 & $3,270,000$ & 123 & 1,460 & 13,200 & 15,200 \\
\hline 1,1,2-Trichloroethane & 2,100 & 8,540 & 61.0 & ND & 80.2 & ND \\
\hline 1,1-Dichloroethane & ND & 8.99 & ND & ND & ND & ND \\
\hline 1,1-Dichloroethylene & 31.3 & 77.6 & ND & $\mathrm{ND}$ & ND & ND \\
\hline 1,2-Dichloroethane & 40.1 & 62.4 & $\mathrm{ND}$ & $\mathrm{ND}$ & $\mathrm{ND}$ & ND \\
\hline Acetone & 177 & 113 & 275 & $\mathrm{ND}$ & 324 & ND \\
\hline Benzene & 19.1 & 83.1 & ND & $\mathrm{ND}$ & ND & ND \\
\hline Carbon tetrachloride & 17.1 & 172 & $\mathrm{ND}$ & ND & $\mathrm{ND}$ & ND \\
\hline Chloroform & 142 & 445 & ND & $\mathrm{ND}$ & $\mathrm{ND}$ & ND \\
\hline Methylene chloride & 44.9 & 41.2 & 36.1 & $\mathrm{ND}$ & 36.2 & ND \\
\hline Tetrachloroethylene & $\mathrm{ND}$ & 25,700 & ND & ND & $\mathrm{ND}$ & ND \\
\hline Toluene & $\mathrm{ND}$ & ND & $\mathrm{ND}$ & $\mathrm{ND}$ & $\mathrm{ND}$ & ND \\
\hline trans-1,2-Dichloroethylene & 3,860 & 3,220 & $\mathrm{ND}$ & ND & 50.4 & ND \\
\hline Trichloroethylene & 6,780 & 263,000 & 843 & 26,000 & 517 & ND \\
\hline Vinyl chloride & 315 & 302 & $\mathrm{ND}$ & ND & ND & $\mathrm{ND}$ \\
\hline Xylenes & $\mathrm{ND}$ & ND & ND & ND & $\mathrm{ND}$ & ND \\
\hline \multicolumn{7}{|c|}{ Semivolatile Organic Compounds } \\
\hline 2-Methylnaphthalene & ND & ND & $\mathrm{ND}$ & ND & ND & ND \\
\hline Hexachloroethane & ND & 628 & ND & 498 & $\mathrm{ND}$ & ND \\
\hline Pyrene & ND & ND & ND & $\mathrm{ND}$ & $\mathrm{ND}$ & ND \\
\hline \multicolumn{7}{|l|}{$P C B 8$} \\
\hline Aroclor 1248 & $\mathrm{ND}$ & 178 & ND & ND & ND & ND \\
\hline Aroclor 1254 & $\mathrm{ND}$ & ND & 1,700 & 3,160 & ND & $\mathrm{ND}$ \\
\hline \multicolumn{7}{|c|}{ a Only detected analytes are reported; for samples with duplicate analyses, the higher value is reported. } \\
\hline \multicolumn{7}{|c|}{ b TCL = Target Compound List. } \\
\hline \multicolumn{7}{|c|}{ c Sample depth shown in parentheses. } \\
\hline $\mathrm{ND}=$ not detected. & & & & & & \\
\hline
\end{tabular}


TABLE 2.6 Analytical Results for Target Analyte List Analytes in Selected Soil Samples from the Toxic Burning Pits, $1992^{\mathrm{a}}$

\begin{tabular}{|c|c|c|c|c|c|c|c|c|c|c|c|}
\hline \multirow[b]{2}{*}{ TAL $^{\mathrm{b}}$ Analyte } & \multicolumn{11}{|c|}{ Concentration (mg/kg) by Soil Sample Location } \\
\hline & \multicolumn{2}{|c|}{ JBP1-E $\left(2^{\prime}\right)^{c}$} & \multicolumn{2}{|c|}{ JBP1-E(4') } & \multicolumn{2}{|c|}{ JBP2-E(2') } & \multicolumn{2}{|c|}{ JBP2-E(4') } & $\operatorname{JVXP}\left(4^{\prime}\right)$ & $\operatorname{JVXP}\left(6^{\prime}\right)$ & JSDP(4') \\
\hline Antimony & \multicolumn{3}{|c|}{5.08} & $\mathrm{ND}^{\mathrm{d}}$ & \multirow{2}{*}{\multicolumn{2}{|c|}{$\begin{array}{r}\text { ND } \\
3.50\end{array}$}} & & ND & ND & $\mathrm{ND}$ & ND \\
\hline Arsenic & \multicolumn{2}{|c|}{5.02} & \multicolumn{2}{|r|}{4.18} & & & & 2.33 & 1.19 & $\mathrm{ND}$ & 1.38 \\
\hline Beryllium & \multicolumn{2}{|c|}{0.309} & \multicolumn{2}{|r|}{0.453} & \multicolumn{2}{|r|}{0.228} & & 0.380 & ND & $\mathrm{ND}$ & $\mathrm{ND}$ \\
\hline Cadmium & \multicolumn{2}{|c|}{3.21} & \multicolumn{2}{|r|}{ ND } & \multicolumn{2}{|r|}{$\mathrm{ND}$} & & ND & ND & ND & ND \\
\hline Chromium & \multicolumn{2}{|c|}{36.6} & \multicolumn{2}{|r|}{18.2} & \multicolumn{2}{|r|}{14.2} & & 12.7 & 5.33 & 3.15 & 4.09 \\
\hline Cobalt & \multicolumn{2}{|c|}{5.64} & \multicolumn{2}{|r|}{ ND } & \multicolumn{2}{|r|}{ ND } & & ND & ND & ND & ND \\
\hline Copper & \multicolumn{2}{|c|}{248} & & 10.1 & & 6.85 & & 10.1 & ND & ND & ND \\
\hline Lead & & 340 & & 10.5 & & 15.9 & & 96.3 & 10.5 & 2.6 & 3.37 \\
\hline Zinc & & 220 & & 123 & & 94.4 & & 76.5 & 33.8 & 13.1 & 13.5 \\
\hline & & & & Conce & ntratic & $\mathrm{n}(\mathrm{mg} / \mathrm{kg}$ & g) by $\mathrm{S}$ & il Samp & le Location & & \\
\hline TAL Analyte & $\operatorname{JSDP}\left(6^{\prime}\right)$ & JHI & $P\left(4^{\prime}\right)$ & JHDP & $?\left(6^{\prime}\right)$ & JBPM- & $A\left(3^{\prime \prime}\right)$ & JBPN & $-A\left(1^{\prime}\right)$ & JBPM-B(3") & JBPM-B(1') \\
\hline Antimony & ND & & ND & & ND & & $\mathrm{ND}$ & & ND & 13.7 & ND \\
\hline Arsenic & $\mathrm{ND}$ & & 3.94 & & 6.29 & & 4.80 & & 22.5 & 7.49 & 3.58 \\
\hline Beryllium & $\mathrm{ND}$ & & 0.457 & & .408 & & 0.434 & & 0.263 & 0.339 & 0.398 \\
\hline Cadmium & ND & & ND & & 7.23 & & 2.95 & & 6.05 & 5.94 & ND \\
\hline Chromium & 5.54 & & 11.9 & & 44.1 & & 37.8 & & 67.9 & 53.4 & 15.6 \\
\hline Cobalt & $\mathrm{ND}$ & & ND & & $\mathrm{ND}$ & & ND & & ND & 6.41 & ND \\
\hline Copper & ND & & ND & & 123 & & 305 & & 392 & 521 & 4.77 \\
\hline Lead & 8.22 & & 10.5 & & 121 & & 145 & & 542 & 79,800 & 11.2 \\
\hline Zinc & 12.8 & & 25.1 & & 296 & & 690 & & 678 & 1,000 & 46.9 \\
\hline
\end{tabular}

a Only detected analytes are reported; for samples with duplicate analyses, the higher value is reported.

b $\mathrm{TAL}=$ Target Analyte List.

c Sample depth shown in parentheses.

d $\mathrm{ND}=$ not detected

Source: Mazelon (1993). 


\section{Surface Water}

Surface water samples (J15 and J16) were collected from the TBP area as part of the 1986 RFA (Nemeth 1989). Sampling locations are shown in Figure 2.10. Samples were analyzed for metals, explosives-related compounds, inorganic compounds, gross alpha, gross beta, radium-226, radium-228, VOCs, semivolatile compounds, and PCBs. The results are summarized in Table 2.7 for locations J15 and J16.

The surface water contained some lead contamination. The lead concentration at location 16 was above the primary drinking water standard $(50 \mu \mathrm{g} / \mathrm{L})$. The gross alpha radionuclide was also slightly elevated at location 16 . The radioactivity measurements were consistent with results from a field radiation survey of the TBP for materials emitting beta and gamma radioactivity. No radiation above background levels was detected (Nemeth 1989).

TABLE 2.7 Analytical Results for Surface Water Samples from the Toxic Burning Pits Area, 1986

\begin{tabular}{|c|c|c|}
\hline \multirow[b]{2}{*}{ Parameter $^{\mathbf{a}}$} & \multicolumn{2}{|c|}{ Location } \\
\hline & J15 & J16 \\
\hline \multicolumn{3}{|l|}{ Dissolved Metals ( $\mu \mathrm{g} / L)$} \\
\hline Cadmium & $<1.0$ & 2.0 \\
\hline Lead & 40 & 104 \\
\hline Mercury & 0.60 & $<0.20$ \\
\hline \multicolumn{3}{|c|}{ Inorganic Compounds ( $\mu g / L)$} \\
\hline Nitrate and nitrite as $\mathrm{N}$ & $<30$ & 60 \\
\hline Sulfate & 12,000 & 16,000 \\
\hline Chloride & 3,000 & 4,000 \\
\hline Total dissolved solids & $\mathrm{NA}^{\mathrm{b}}$ & 34,000 \\
\hline \multicolumn{3}{|l|}{ Radioactivity (pCi/L) } \\
\hline Gross alpha & $<0.8$ & 7.0 \\
\hline Gross beta & 5.7 & 15 \\
\hline Radium-226 & $\mathrm{NA}$ & 0.50 \\
\hline Radium-228 & $\mathrm{NA}$ & 1.4 \\
\hline
\end{tabular}

a Includes parameters that were detected in one or more samples. No detection limits given for VOCs, semivolatile compounds, and PCBs.

b $\mathrm{NA}=$ Not analyzed.

Source: Nemeth (1989). 
The USGS collected nearshore surface water samples from the Gunpowder River (9 locations) and the Chesapeake Bay (11 locations) at low tide. One sample was collected onshore in a drainage ditch. Sampling locations are shown in Figure 2.13. Filtered and unfiltered samples were analyzed for water quality parameters, metals, and a few organic compounds. Nitrate concentrations in samples from locations 3, 7, and 13 ranged from 280 to $400 \mu \mathrm{g} / \mathrm{L}$. The metals data showed the presence of lead (from not detected [ND] ${ }^{1}$ to $28 \mu \mathrm{g} / \mathrm{L})$ and zinc $(50-133 \mu \mathrm{g} / \mathrm{L})$ at locations 1 through 4 . Lead and zinc concentrations at the other locations ranged from ND to 2.68 and $48 \mu \mathrm{g} / \mathrm{L}$, respectively. Mercury and nickel concentrations were slightly elevated at location 1 ( 0.54 and $33.7 \mu \mathrm{g} / \mathrm{L}$, respectively). No evidence was found of elevated concentrations of arsenic, barium, or chromium. Comparison of results from filtered and unfiltered samples showed that the elevated metals concentrations may be associated with the suspended solids in the samples (Hughes 1993).

Acetone, toluene, phenol, total organic carbon (TOC), and total organic halogen (TOX) were analyzed in the filtered and unfiltered samples from nine locations. Phenol (ND to $51.9 \mu \mathrm{g} / \mathrm{L})$, TOC $(4,000-7,000 \mu \mathrm{g} / \mathrm{L})$, and TOX $(21.6-30.4 \mu \mathrm{g} / \mathrm{L})$ were detected in the unfiltered samples only. The presence of acetone in some of the samples may represent laboratory contamination. Toluene (3.05 $\mu \mathrm{g} / \mathrm{L}$ ) was found at location 1 (Hughes 1993).

The data for the nearshore surface water have shown essentially no contamination. Contaminants appear to be associated with the suspended solids, suggesting that the nearshore sediments may be contaminated.

In August 1992, the EPA emergency response team (ERT) collected nearshore surface water and sediment samples at 17 locations around the peninsula - in the Gunpowder and Bush rivers and in Chesapeake Bay (Figure 2.14). Filtered surface water samples were analyzed for VOCs, base neutral and acid extractable organic compounds (BNA), Target Analyte List (TAL) metals, pesticides, PCBs, and inorganic parameters (sulfate, total Kjeldahl nitrogen [TKN], total phosphorus, and cyanide). The data showed that beryllium, lead, and mercury were below their respective detection limits of $6,000,6,000$, and $200 \mu \mathrm{g} / \mathrm{L}$. Zinc concentrations ranged from $11,000 \mu \mathrm{g} / \mathrm{L}$ at locations 3,4 , and 16 to $96,000 \mu \mathrm{g} / \mathrm{L}$ at location 6 . Nickel concentrations ranged from $28,000 \mu \mathrm{g} / \mathrm{L}$ at most locations to $38,000 \mu \mathrm{g} / \mathrm{L}$ at location 9 . No cyanide, VOCs, pesticides, or PCBs were detected.

Sediment samples, collected at the same locations as the surface water, were analyzed for CWAs and CWA degradation products, explosives, VOCs, BNA, TAL metals, pesticides, PCBs, and other parameters (TOC, sulfate, total phosphorus, TKN, and percent solids). The results indicate that there is essentially no contamination in sediments at these locations, although lead was detected at concentrations ranging from $2 \mathrm{mg} / \mathrm{L}$ at location 11 to $22 \mathrm{mg} / \mathrm{L}$ at location 17. Arsenic and cadmium were also detected: arsenic at concentrations ranging from 1 to $6 \mathrm{mg} / \mathrm{L}$ (at location 6) and cadmium at concentrations

1 The detection limits for analyses were not reported. 


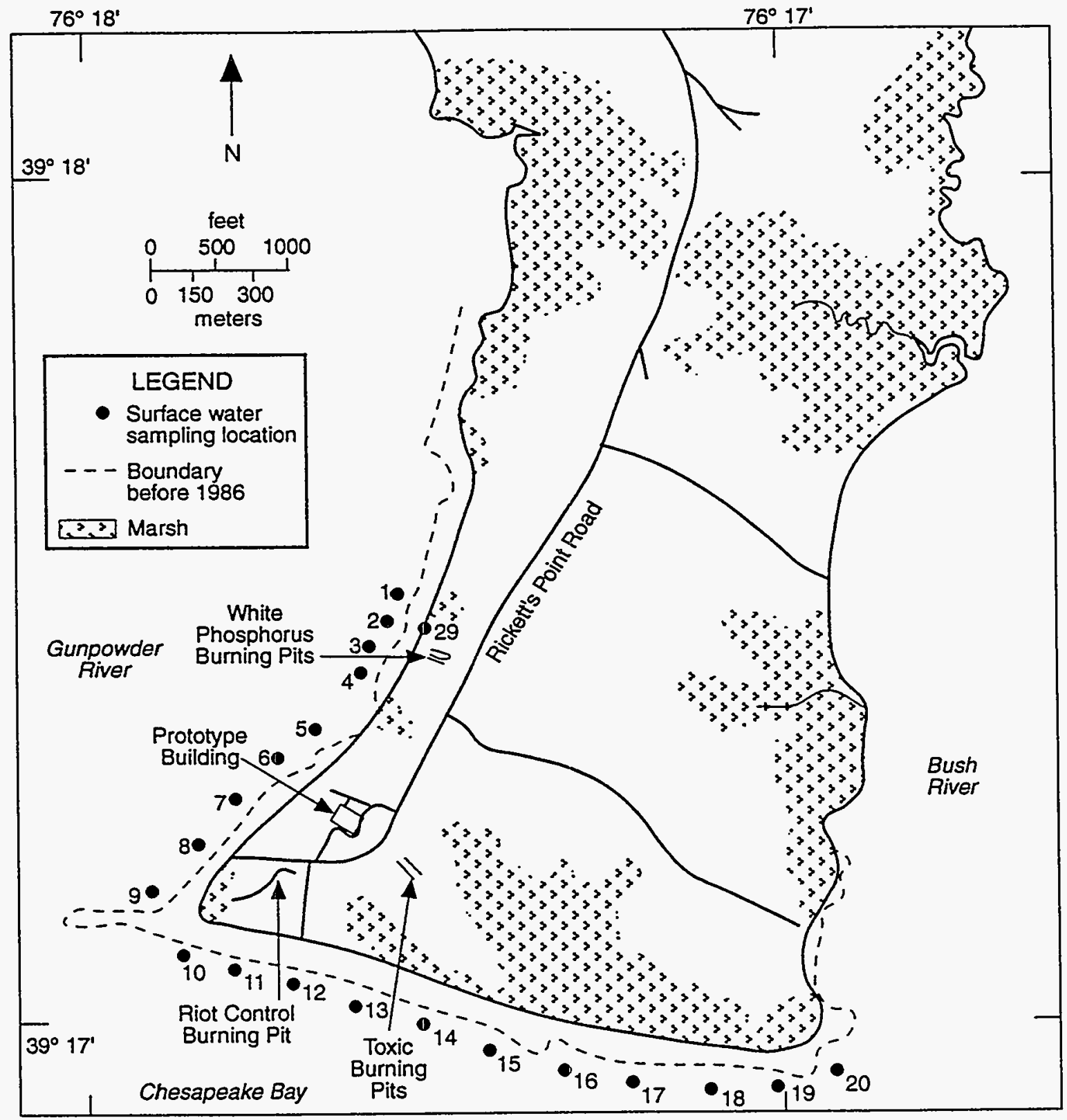

FIGURE 2.13 Locations of Surface Water Samples Collected from the Gunpowder River and Chesapeake Bay in the Immediate Vicinity of J-Field in 1988 (Source: Adapted from USGS 1991) 


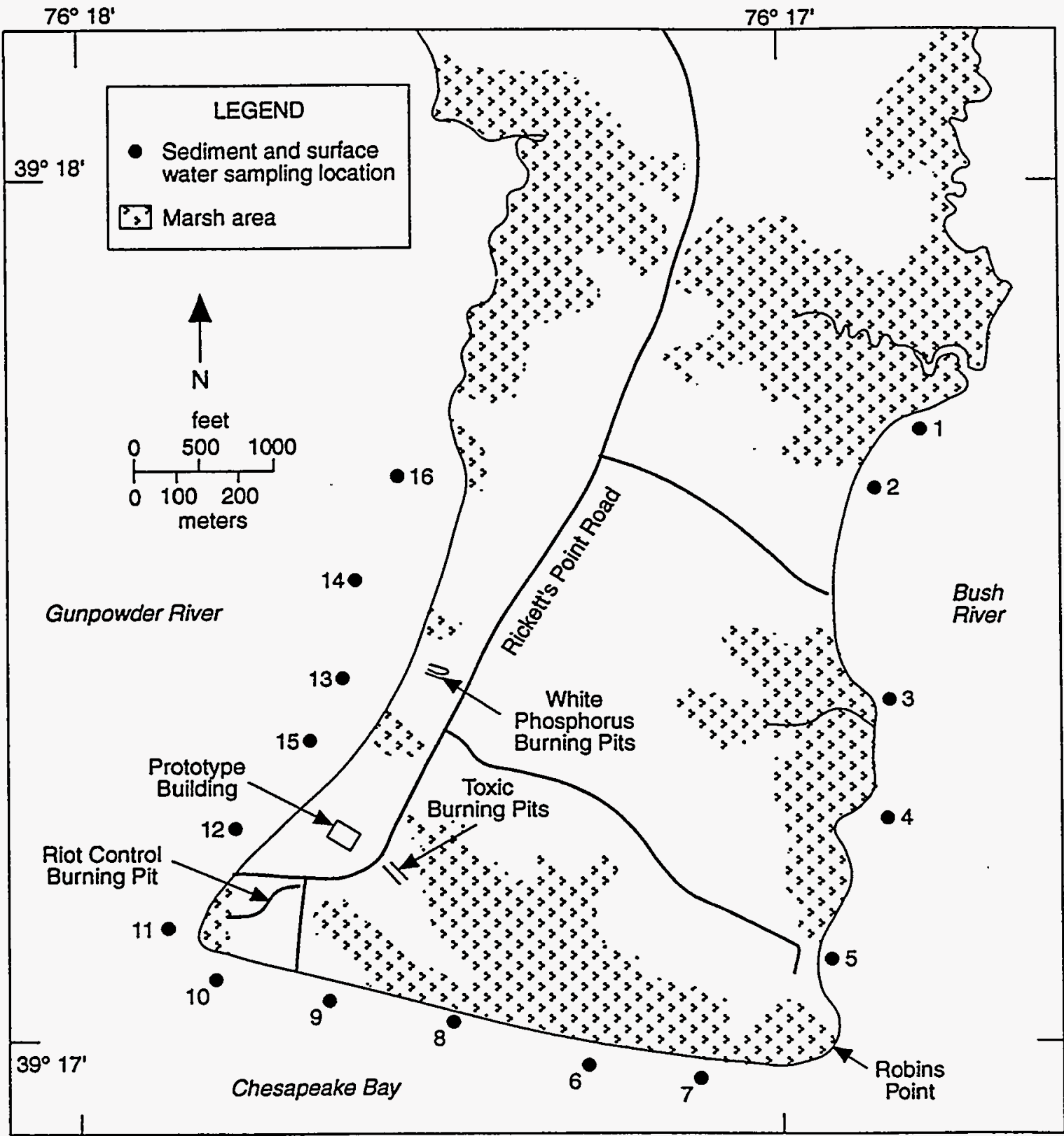

FIGURE 2.14 Locations of Nearshore Surface Water and Sediment Samples Collected from around the J-Field Peninsula in 1992 (Source: EPA 1992a) 
ranging from $<0.5$ to $3 \mathrm{mg} / \mathrm{L}$ (at location 8). The detection limit for beryllium was fairly high, ranging from 0.5 to $2.6 \mathrm{mg} / \mathrm{L}$. The only VOC detected was acetone, up to $101 \mu \mathrm{g} / \mathrm{kg}$ at location 7.

\section{Groundwater}

Eleven groundwater monitoring wells (TH series) were installed in J-Field during the 1977 environmental survey. Locations of these wells are shown in Figure 2.15. Only one well (TH4) was installed in the area of the TBP. Well depths ranged from 20 to $25 \mathrm{ft}$. The wells were screened in the surficial aquifer with 25-ft-long screens (Sonntag 1991). Samples collected from the wells in 1977 were analyzed for metals, inorganic chemicals, white phosphorus, mustard degradation products, cholinesterase inhibitors, semivolatile compounds, and VOCs. Organic contaminants (up to $200,000 \mu \mathrm{g} / \mathrm{L}$ ) were found in all of the wells (no data were given for $\mathrm{TH} 7$ ).

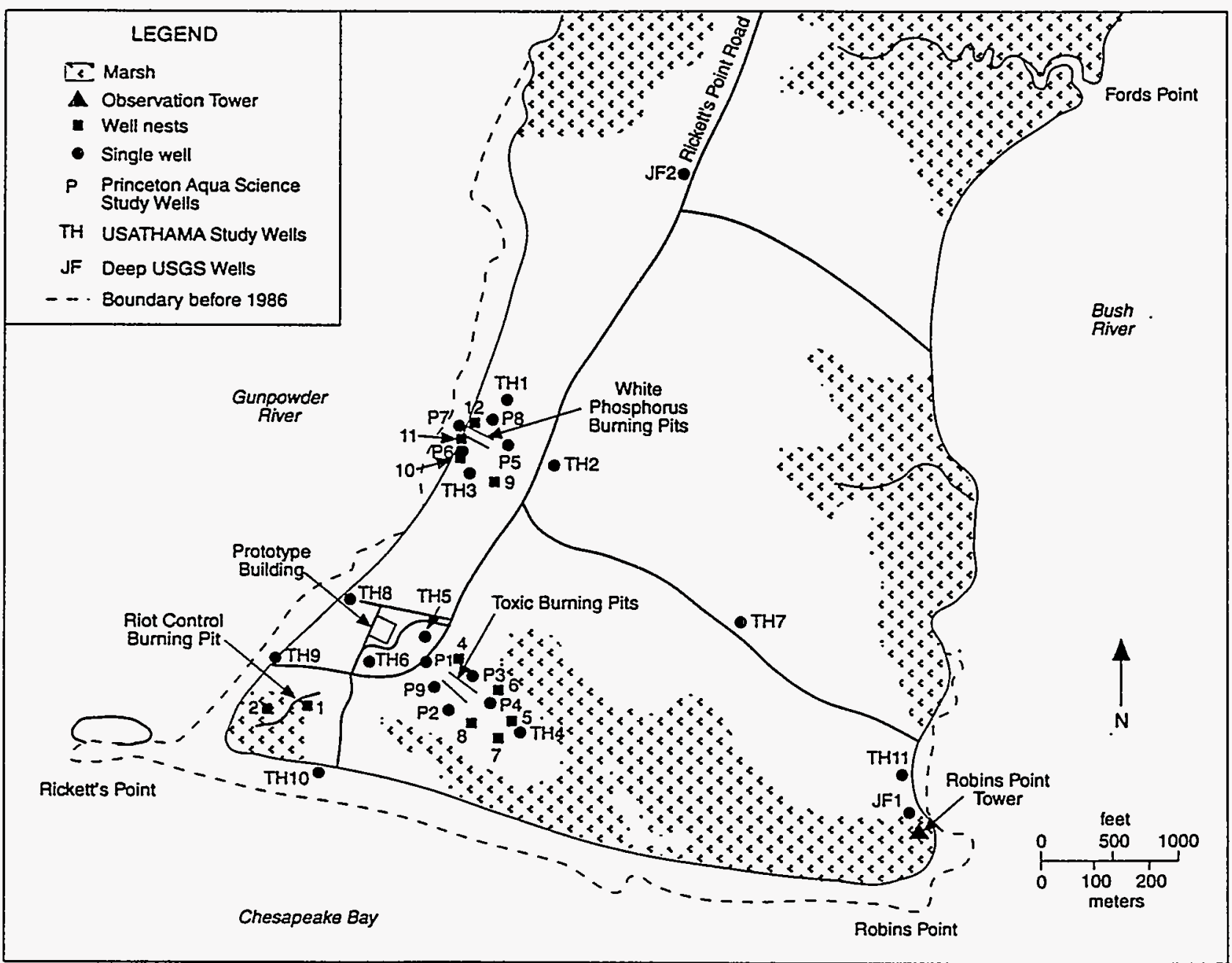

FIGURE 2.15 Locations of All Wells Installed at J-Field (Source: Adapted from Hughes 1993) 
Five additional wells were installed around the TBP as part of a munitions disposal study (Figure 2.15, P series) (Princeton Aqua Science 1984). The wells were screened in the surficial aquifer from depths of $17-20 \mathrm{ft}$ with 15-ft-long screens (Sonntag 1991). Water samples collected from the wells in 1983 were analyzed for metals, nitrate, TOX, TOC, radioactivity, pesticides, herbicides, and secondary drinking water parameters. Two of the five wells (P4 and P5) contained elevated concentrations of the gross beta radionuclide (140 and $12 \mathrm{pCi} / \mathrm{L}$, respectively). Two wells (P3 and P4) contained TOX (6.6 and $7.1 \mathrm{mg} / \mathrm{L}$, respectively). Two wells (P2 and P5) contained elevated concentrations of nitrates (12 and $10 \mathrm{mg} / \mathrm{L}$, respectively).

The P-series wells were sampled again in 1986 as part of the Edgewood Area RFA (Nemeth 1989). The samples were analyzed for metals, explosives-related compounds, inorganic compounds, radioactivity, thiodiglycol, VOCs, semivolatile compounds, and PCBs. The results are summarized in Table 2.8. Elevated concentrations of VOCs were found in only two wells (P3 and P4), near the area exhibiting soil-gas contamination. The compounds found include trans-1,2-dichloroethylene (trans-12DCE), up to 8,500 $\mu / \mathrm{L}$ in well P4; TRCLE, up to $6,700 \mu \mathrm{g} / \mathrm{L}$ in well P4; vinyl chloride, up to $550 \mu \mathrm{g} / \mathrm{L}$ in well P3; and TCLEE, up to $420 \mu \mathrm{g} / \mathrm{L}$ in well P3. The data also indicate that the elevated gross beta activity detected in well P3 was due to naturally occurring potassium-40; however, it is not clear why potassium concentrations were so much higher in this well than in the others.

Thirty-eight additional monitoring wells were installed by the USGS in 1988 and 1989 (Sonntag 1991; Hughes 1993). Two of these wells, JF1 and JF2, were installed and screened in the Potomac Group. The 36 other wells were placed in nests of 3 at 12 different locations (Figure 2.15). Well nests JF3-JF8 were placed in the TBP area. The nested wells were screened in the confined aquifer, the leaky confining unit, and the surficial aquifer. The naming convention for the well nests involves a combination of letters and numbers. The letters with numbers (i.e., JF1-JF12) indicate the location. This location indicator code is then coupled with the numbers 1,2 , or 3 to indicate the strata being monitored. The confined aquifer is designated by the number 1 , the leaky confining unit by the number 2 , and the surficial aquifer by the number 3 .

During 1990, samples from 55 of the 58 existing wells at J-Field were analyzed for metals, inorganic compounds, VOCs, and semivolatile organic compounds. Several of the wells were also analyzed for organosulfur, explosives, and radioactive contaminants. Wells were selected for specific contaminant analyses on the basis of the nature of disposal activities that had occurred nearby (USGS 1991).

Table 2.9 summarizes the analytical results indicating the presence of metals and other inorganic compounds. Concentrations of lead $(124 \mu \mathrm{g} / \mathrm{L})$ in well P9 and arsenic $(60 \mu \mathrm{g} / \mathrm{L})$ in well $\mathrm{JF} 83$ exceed maximum contaminant levels (MCLs). Both of these wells are downgradient from the TBP. Potassium concentrations ranged from not detected to $140 \mu g / \mathrm{L}$ 
TABLE 2.8 Analytical Results for Groundwater from the P-Series Monitoring Wells, 1986

\begin{tabular}{|c|c|c|c|c|c|}
\hline \multirow[b]{2}{*}{ Parameter $^{\mathrm{a}}$} & \multicolumn{5}{|c|}{ Concentration by Well } \\
\hline & P1 & P2 & P3 & P4 & P9 \\
\hline \multicolumn{6}{|c|}{ Dissolved Metals ( $\mu \mathrm{g} / L)$} \\
\hline Arsenic & $<10$ & $<10$ & 24 & $<10$ & $<10$ \\
\hline Cadmium & $<1$ & $<1$ & $<1$ & 3 & $<1$ \\
\hline Lead & $<5$ & $<5$ & $<5$ & 90 & $<5$ \\
\hline Selenium & $<5$ & 9 & 54 & 26 & $<5$ \\
\hline Potassium & 1,040 & 733 & 113,000 & 1,380 & 782 \\
\hline \multicolumn{6}{|c|}{ Inorganic Compounds ( $\mu g / L)$} \\
\hline Nitrate/nitrite as $\mathrm{N}$ & 490 & 12,000 & $<50$ & $<50$ & 8,000 \\
\hline Sulfate & 54,000 & 105,000 & 362,000 & 93,000 & 94,000 \\
\hline Chloride & 4,800 & 23,000 & 304,000 & 866,000 & 24,000 \\
\hline Total phosphate as $P$ & $\mathrm{NA}^{\mathrm{b}}$ & NA & NA & NA & NA \\
\hline Total dissolved solids & 125,000 & 328,000 & $1,403,000$ & $1,087,000$ & 262,000 \\
\hline \multicolumn{6}{|l|}{ Radioactivity (pCi/L) } \\
\hline Gross beta & 1.3 & 2.5 & 100 & $<4.8$ & 1.4 \\
\hline Potassium-40 & NA & NA & 120 & NA & NA \\
\hline Radium-226 & NA & NA & 0.43 & NA & NA \\
\hline \multicolumn{6}{|c|}{ Volatile Organic Compounds ( $\mu \mathrm{g} / L)$} \\
\hline Benzene & $\mathrm{ND}^{\mathrm{c}}$ & ND & 6.0 & ND & ND \\
\hline Chlorobenzene & ND & ND & 980 & ND & ND \\
\hline Ethyl benzene & ND & ND & 3.0 & ND & ND \\
\hline Toluene & ND & ND & 5.0 & ND & ND \\
\hline Chloroform & ND & ND & 7.0 & 3.0 & ND \\
\hline Carbon tetrachloride & ND & 5.0 & ND & ND & ND \\
\hline 112TCE & ND & ND & 7.0 & 130 & ND \\
\hline TCLEA & ND & ND & ND & 200 & 5.0 \\
\hline Vinyl chloride & ND & ND & 550 & 48 & $\mathrm{ND}$ \\
\hline trans-12DCE & ND & ND & 2,220 & 8,500 & ND \\
\hline TRCLE & ND & ND & 980 & 6,700 & 5.0 \\
\hline TCLEE & ND & ND & 420 & ND & ND \\
\hline
\end{tabular}

a Includes all parameters that were detected at least once. Metals analyzed but not detected: barium $(<300 \mu \mathrm{g} / \mathrm{L})$, chromium $(<10 \mu \mathrm{g} / \mathrm{L})$, mercury $(<0.2 \mu \mathrm{g} / \mathrm{L})$, and silver $(<25 \mu \mathrm{g} / \mathrm{L})$.

b $\mathrm{NA}=$ not analyzed.

c ND $=$ not detected.

Source: Nemeth (1989). 
TABLE 2.9 Analytical Results for Selected Inorganic Compounds, TOC, and Metals in Groundwater from the Toxic Burning Pits, 1990

\begin{tabular}{|c|c|c|c|c|c|c|c|c|c|}
\hline Well & $\begin{array}{c}\text { Chloride } \\
(\mathrm{mg} / \mathrm{L})\end{array}$ & $\begin{array}{c}\text { Potassium } \\
(\mathrm{mg} / \mathrm{L})\end{array}$ & $\begin{array}{c}\mathrm{TOC} \\
(\mathrm{mg} / \mathrm{L})\end{array}$ & $\begin{array}{c}\text { Arsenic } \\
(\mu \mathrm{g} / \mathrm{L})\end{array}$ & $\begin{array}{c}\text { Cyanide } \\
(\mu \mathrm{g} / \mathrm{L})\end{array}$ & $\begin{array}{c}\text { Lead } \\
(\mu g / L)\end{array}$ & $\begin{array}{l}\text { Nickel } \\
(\mu \mathrm{g} / \mathrm{L})\end{array}$ & $\begin{array}{c}\text { Selenium } \\
(\mu \mathrm{g} / \mathrm{L})\end{array}$ & $\begin{array}{c}\text { Zinc } \\
(\mu \mathrm{g} / \mathrm{L})\end{array}$ \\
\hline P2 & $<100$ & $<50$ & $<10$ & $\mathrm{ND}^{\mathrm{a}}$ & ND & ND & ND & 3.8 & ND \\
\hline P3 & $<100$ & 61.8 & 25 & 30.2 & ND & ND & 61.9 & ND & ND \\
\hline P4 & 390 & $<50$ & $<10$ & ND & ND & ND & ND & ND & 292 \\
\hline P9 & $<100$ & $<50$ & $<10$ & ND & ND & 124 & ND & ND & ND \\
\hline TH4 & $<100$ & $<50$ & $<10$ & ND & ND & ND & ND & 2.35 & $\mathrm{ND}$ \\
\hline JF51 & $<100$ & 140 & $<10$ & ND & 13.9 & ND & ND & ND & ND \\
\hline JF52 & $<100$ & $<50$ & $<10$ & ND & ND & ND & ND & ND & ND \\
\hline JF53 & $<100$ & $<50$ & $<10$ & ND & ND & ND & 440 & ND & ND \\
\hline JF61 & $<100$ & 98 & 160 & 8.03 & ND & ND & ND & ND & ND \\
\hline JF62 & $<100$ & $<50$ & 10 & ND & ND & ND & ND & ND & ND \\
\hline JF63 & 180 & $<50$ & 50 & 4.11 & ND & ND & ND & ND & ND \\
\hline JF71 & $<100$ & 79 & $<10$ & 3.32 & ND & ND & ND & ND & ND \\
\hline JF72 & $<100$ & $<50$ & 180 & ND & ND & ND & ND & 3.21 & ND \\
\hline JF73 & $<100$ & $<50$ & $<10$ & 5.52 & ND & ND & ND & ND & ND \\
\hline JF81 & 130 & $<50$ & $<10$ & ND & ND & ND & ND & ND & ND \\
\hline JF82 & $<100$ & 74.7 & 100 & 20.4 & 88 & ND & ND & ND & ND \\
\hline JF83 & 120 & $<50$ & $<10$ & 60 & ND & ND & ND & 6.18 & ND \\
\hline
\end{tabular}

a $\mathrm{ND}=$ not detected.

Source: USGS (1991). 
Except for one measurement at well P3, the elevated concentrations of potassium (above $50 \mu \mathrm{g} / \mathrm{L}$ ) occurred in the leaky confining unit or the confined aquifer. Movement of sea water into the groundwater may not be a source of potassium because wells with elevated potassium do not have elevated chloride concentrations.

The analytical results (summarized in Table 2.10) show that the TBP are contaminated with VOCs, and a contaminant plume in the groundwater extends downgradient to the southeast. This condition is reflected in the elevated concentrations of 112TCE, 1,2-dichloroethylene (12DCE), TCLEA, TCLEE, and TRCLE in well nests JF5, JF7, and JF8. The concentrations are highest in the surficial aquifer - up to 7,150 $\mu \mathrm{g} / \mathrm{L} 12 \mathrm{DCE}$ in wells JF73 and JF83. The data also show that some contamination extends down into the leaky confining unit and the confined aquifer (1,400 $\mathrm{\mu g} / \mathrm{L}$ TRCLE in the leaky confining unit [JF82] and 7,100 $\mu \mathrm{g} / \mathrm{L} \mathrm{112TCE}$ in the confined aquifer [JF81]). Because the well screens monitoring the confined aquifer are at depths of $70 \mathrm{ft}$ or more (well JF81 is screened at a depth of 120-123 ft), VOC contamination extends more than $100 \mathrm{ft}$ deep.

Because TRCLE was detected most often, the TRCLE data were used to create a contour map of contamination in the surficial aquifer (Figure 2:16). Those contours show that a plume of contaminated groundwater extends south of the TBP area to the shore and, possibly, into the bay. Additional data on VOC concentrations in the groundwater at locations farther south and closer to the shore are needed to determine if the plume in the surficial aquifer extends into the bay.

Data for the single wells screened in the Potomac Group sediments (JF1 and JF2) indicate low concentrations of VOC contamination in the deeper strata. Well JF1 contained $2.25 \mu \mathrm{g} / \mathrm{L}$ 1,1,1-trichloroethane (111TCE) at a depth of 185-190 ft; well JF2 contained $6.7 \mu \mathrm{g} / \mathrm{L}$ TRCLE at $208-213 \mathrm{ft}$. These values are questionable because one of the two blanks associated with the sampling event contained detectable concentrations of TCLEA, TCLEE, and TRCLE.

Groundwater samples from a few wells were analyzed for explosives and organosulfur compounds. Results are summarized in Table 2.11. The data indicate some contamination with organosulfur compounds (including degradation products of mustard) in the surficial aquifer downgradient from the TBP. The maximum concentration was $140 \mu \mathrm{g} / \mathrm{L}$ 1,4-dithiane in well P3 just north of the western end of the TBP. No organosulfur contamination was found in the middle or lower aquifers. Explosives-related compounds were also found in low concentrations (up to $226 \mu \mathrm{g} / \mathrm{L}$ nitrocellulose) in the water table and the lower aquifer. Because nitrocellulose is not soluble in water, this value is either lab error or due to suspended solids in the groundwater sample.

Concentrations of the radioactive species uranium, thorium-230, cesium-137, and strontium-90 were measured in monitoring wells P1, P3, P4, JF53, JF52, JF51, JF63, and JF73. Elevated concentrations of cesium-137 (up to $172 \mathrm{pCi} / \mathrm{L}$ ) and strontium-90 (up to $128 \mathrm{pCi} / \mathrm{L}$ ), measured as beta radiation, were found in wells P3, JF51, and JF73 (USGS 1991). If these values are confirmed by additional measurements, they would indicate the presence of radioactive contaminants. 
TABLE 2.10 Analytical Results for Selected VOCs in Groundwater from the Toxic Burning Pits Area, 1990

\begin{tabular}{|c|c|c|c|c|c|c|c|c|c|}
\hline \multirow[b]{2}{*}{ Well $^{\mathrm{a}}$} & \multicolumn{9}{|c|}{ VOC $^{b}$ Concentrations ( $\left.\mu \mathrm{g} / \mathrm{L}\right)$} \\
\hline & 112TCE & 11DCE & 12DCE & $\mathrm{C} 2 \mathrm{H} 3 \mathrm{CL}$ & C6H6 & CHCL3 & TCLEA & TCLEE & TRCLE \\
\hline P2 & 4.02 & $N D^{c}$ & 10.2 & ND & ND & ND & 101 & ND & 440 \\
\hline $\mathrm{TH} 4$ & ND & ND & ND & ND & ND & ND & 3.73 & ND & ND \\
\hline JF53 & 110 & 8.04 & 850 & 132 & $\mathrm{ND}$ & ND & 3,500 & ND & 820 \\
\hline JF52 & 10 & ND & 420 & ND & ND & 2.2 & 34.3 & $\mathrm{ND}$ & 52 \\
\hline JF51 & $\mathrm{ND}$ & 3.79 & 430 & ND & ND & ND & ND & ND & 520 \\
\hline JF63 & ND & $\mathrm{ND}$ & 7.33 & ND & ND & 7.6 & ND & 17.6 & 600 \\
\hline JF62 & ND & ND & ND & ND & ND & ND & $\mathrm{ND}$ & ND & 2.7 \\
\hline JF61 & ND & ND & ND & ND & ND & ND & ND & $\mathrm{ND}$ & 1.8 \\
\hline JF73 & 67.3 & 6.81 & 7,150 & ND & ND & 2.9 & 340 & ND & 1,800 \\
\hline JF72 & ND & ND & 32.6 & ND & $\mathrm{ND}$ & 1.9 & ND & $\mathrm{ND}$ & 4.5 \\
\hline JF71 & ND & ND & ND & ND & ND & 24 & ND & ND & 7.3 \\
\hline JF83 & 7,100 & 19 & 7,150 & 56.3 & 4.88 & 50 & 250 & 1,000 & 4,900 \\
\hline JF82 & ND & 30.1 & 210 & ND & $\mathrm{ND}$ & 5.6 & $\mathrm{ND}$ & 47.2 & 1,400 \\
\hline JF81 & 7,100 & ND & 34.6 & $\mathrm{ND}$ & $\mathrm{ND}$ & ND & 290 & ND & 230 \\
\hline
\end{tabular}

a TBP wells not listed contained no VOCs, or traces of 111TCE, C2H5CL, CCL4, CH3CL, and C6H5CL. No data for wells P1, P3, P4, JF43, JF41.

b Installation Restoration Data Management System (IRDMS) acronyms are used for VOCs: 112TCE = 1,1,2-trichloroethane; 11DCE = 1,1-dichloroethylene; $12 \mathrm{DCE}=1$,2-dichloroethylene; $\mathrm{C} 2 \mathrm{H} 3 \mathrm{CL}=$ vinyl chloride; C6H6 = benzene; CHCL3 = chloroform; TCLEA = 1,1,2,2-tetrachloroethane; TCLEE = tetrachloroethylene; and TRCLE $=$ trichloroethylene.

c $\mathrm{ND}=$ not detected.

Source: USGS (1991). 


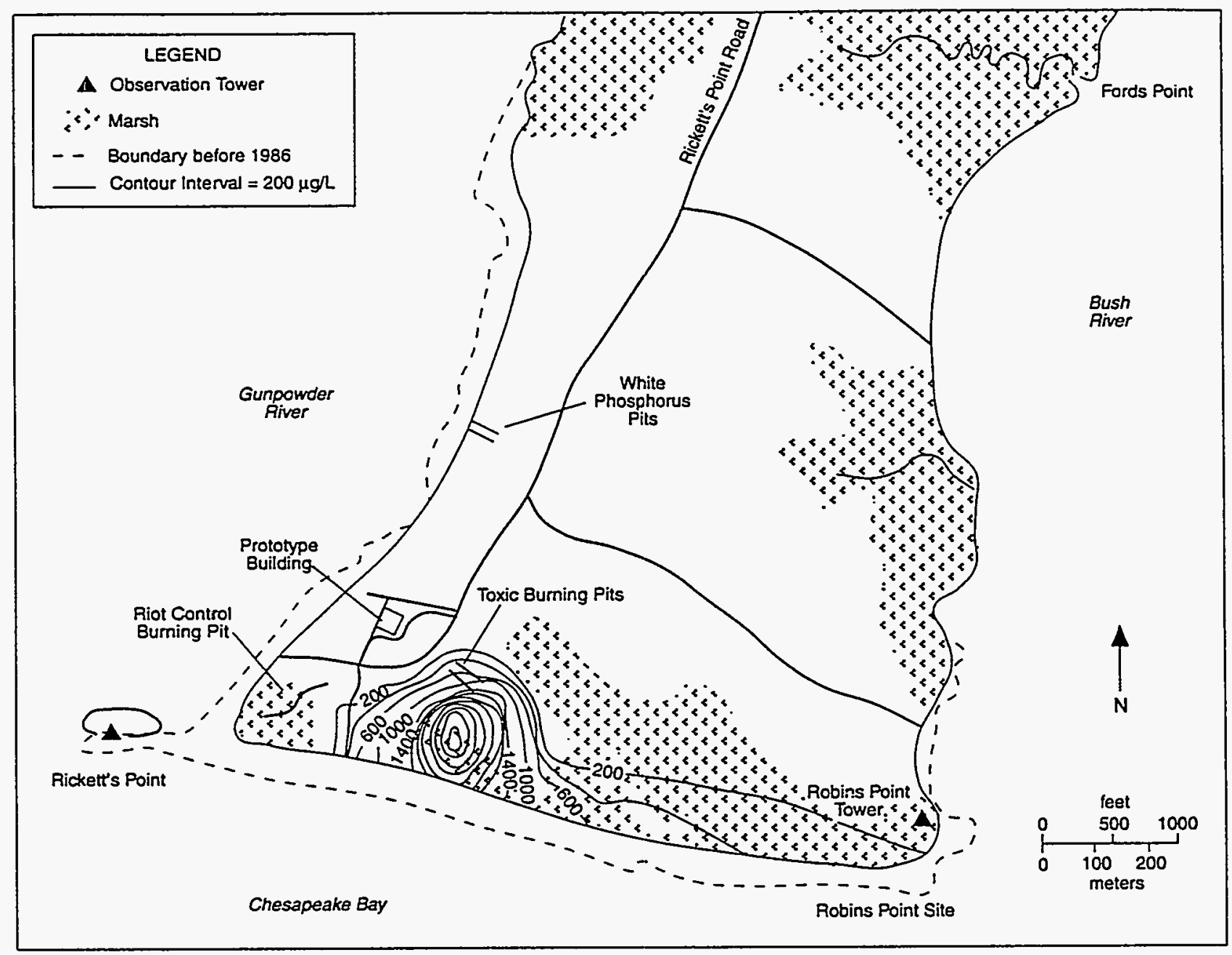

FIGURE 2.16 Contours of TRCLE Concentrations ( $\mu \mathrm{g} / \mathrm{L}$ ) in the Surficial Aquifer (contour interval $=200 \mu \mathrm{g} / \mathrm{L}$ ) (Source: Adapted from Hughes 1993)

In 1992, the USGS analyzed groundwater collected from wells in the TBP area (Figure 2.15) for VOCs (Table 2.12). The data indicate that VOCs are present in the three aquifers underlying J-Field (surficial unit, confining unit, and confined unit); that concentrations of TRCLE, TCLEE, TCLEA, chloroform (CHCL3), 12DCE, and 112TCE have increased significantly since 1990 (see also Table 2.10); and that concentrations of 1,1-dichloroethylene (11DCE) have not been detected.

The highest VOC concentrations were found in well clusters JF5, 6, 7, and 8 in all three aquifers. The greatest increases in concentrations were found in JF83, which monitors the surficial aquifer south of the main burning pits - TRCLE increased from 4,900 $\mu \mathrm{g} / \mathrm{L}$ in 1990 to $41,000 \mu \mathrm{g} / \mathrm{L}$ in 1992 , TCLEE increased from $1,000 \mu \mathrm{g} / \mathrm{L}$ to $3,600 \mu \mathrm{g} / \mathrm{L}$, TCLEA 
TABLE 2.11 Analytical Results for Organosulfur and Explosives-Related Compounds in Groundwater from the Toxic Burning Pits Area, 1990

\begin{tabular}{|c|c|c|c|c|c|}
\hline \multirow[b]{2}{*}{ Well } & \multicolumn{5}{|c|}{ Concentrations of Organosulfur Compounds ( $\mu \mathrm{g} / \mathrm{L}$ ) } \\
\hline & $\begin{array}{l}\text { 4-Chlorophenyl- } \\
\text { methsulfoxide }\end{array}$ & $\begin{array}{l}\text { 4-Chlorophenyl- } \\
\text { sulfone }\end{array}$ & 1,4-Dithiane & 1,4-Oxithiane & Thiodiglycol \\
\hline P3 & $\mathrm{ND}^{\mathbf{a}}$ & ND & 140 & ND & $N A^{b}$ \\
\hline $\mathrm{P} 4$ & ND & ND & 8.28 & ND & $\mathrm{NA}$ \\
\hline JF53 & ND & ND & 2.11 & ND & $\mathrm{ND}$ \\
\hline JF63 & ND & $\mathrm{ND}$ & 8.21 & 8.24 & 21 \\
\hline \multirow[t]{3}{*}{ JF83 } & ND & 20.5 & $\mathrm{ND}$ & ND & NA \\
\hline & \multicolumn{5}{|c|}{ Concentrations of Explosives-Related Compounds ( $\mu \mathrm{g} / \mathrm{L}$ ) } \\
\hline & $\mathrm{DNT}^{\mathrm{c}}$ & $\begin{array}{c}\text { Nitro- } \\
\text { benzene }\end{array}$ & $\begin{array}{l}\text { Nitro- } \\
\text { cellulose }\end{array}$ & $\mathrm{PETN}^{\mathrm{d}}$ & $\mathrm{RDX}^{\mathrm{e}}$ \\
\hline P9 & ND & ND & 226 & ND & 0.496 \\
\hline JF43 & $\mathrm{ND}$ & ND & 21.3 & ND & ND \\
\hline JF51 & $\mathrm{ND}$ & 0.0889 & $\mathrm{ND}$ & ND & $\mathrm{ND}$ \\
\hline JF63 & $\mathrm{ND}$ & ND & ND & 15.9 & $\mathrm{ND}$ \\
\hline JF73 & ND & $\mathrm{ND}$ & $\mathrm{ND}$ & $\mathrm{ND}$ & 1.18 \\
\hline \multicolumn{6}{|c|}{ a $\mathrm{ND}=$ not detected. } \\
\hline \multicolumn{6}{|c|}{ b $\mathrm{NA}=$ no data available. } \\
\hline \multicolumn{6}{|c|}{ DNT = dinitrotoluene. } \\
\hline \multicolumn{6}{|c|}{ d PETN = penta-erythritol tetranitrate. } \\
\hline \multicolumn{6}{|c|}{ e $\mathrm{RDX}=$ hexahydro-1,3,5-trinitro-1,3,4-triazine. } \\
\hline Sourc & USGS (1991). & & & & \\
\hline
\end{tabular}

increased from $250 \mu \mathrm{g} / \mathrm{L}$ to $260,000 \mu \mathrm{g} / \mathrm{L}$, and $12 \mathrm{DCE}$ increased from $7,150 \mu \mathrm{g} / \mathrm{L}$ to $12,000 \mu \mathrm{g} / \mathrm{L}$. Concentrations of $112 \mathrm{TCE}$ decreased from $7,100 \mu \mathrm{g} / \mathrm{L}$ in 1990 to $2,000 \mu \mathrm{g} / \mathrm{L}$ in 1992 (USGS 1992).

\subsubsection{Potential Pathways of Contaminant Migration}

Existing data indicate that the main pathway of contaminant migration at the TBP AOC is movement through the vadose zone down into the groundwater and then transport by groundwater.

Contaminants are apparently moving from their source, down into the groundwater, and then downgradient into the marshes by surficial aquifer discharge or into the estuaries by groundwater upwelling, or to locations even farther downgradient. 
TABLE 2.12 Analytical Results for Selected VOCs in Groundwater Samples from the Toxic Burning Pits Area, 1992

\begin{tabular}{lrrrrrr}
\hline & \multicolumn{7}{c}{ VOC Concentrations ( $\mu \mathrm{g} / \mathrm{L})$} \\
\cline { 2 - 7 } Well $^{\mathrm{a}}$ & 112TCE & 12DCE & C2H3CL & TCLEA & TCLEE & TRCLE \\
\hline & & & & & & \\
P3 & ND $^{\mathrm{c}}$ & 980 & 600 & ND & 3,400 & 570 \\
P4 & 65 & 3,300 & ND & ND & ND & 3,600 \\
P9 & ND & ND & 10 & ND & ND & ND \\
JF53 & 290 & 10,000 & 95 & 4,900 & ND & 4,200 \\
JF52 & 1 & 140 & ND & 1 & ND & 3 \\
JF51 & ND & 210 & ND & ND & ND & 97 \\
JF63 & ND & 120 & ND & 75 & 130 & 4,400 \\
JF62 & ND & 4 & ND & ND & ND & 13 \\
JF61 & ND & 2 & ND & ND & 2 & 10 \\
JF73 & 90 & 920 & ND & 9,000 & 280 & 5,100 \\
JF71 & ND & ND & ND & 2 & ND & 3 \\
JF83 & 2,000 & 12,000 & ND & 260,000 & 3,600 & 41,000 \\
JF82 & ND & 190 & ND & ND & ND & 1,800 \\
JF81 & ND & 22 & ND & 5 & 3 & 220 \\
\hline
\end{tabular}

a TBP wells not listed contained no VOCs. No data were obtained for wells $\mathrm{P} 1, \mathrm{P} 2, \mathrm{JF} 43,42,41$, and JF72.

b $\mathrm{C} 2 \mathrm{H} 3 \mathrm{CL}=$ vinyl chloride.

c $\mathrm{ND}=$ not detected.

Source: USGS (1992).

The direction of groundwater movement in the Talbot aquifers appears to be away from the TBP AOC toward the low-lying marshes and under the Gunpowder and Bush rivers. However, the lateral gradients in the lower aquifers are quite small (USGS 1991). The vertical movement of groundwater appears to be down through the aquifers; however, offshore there may be upward flow from each of the three Talbot aquifers into the Gunpowder and Bush rivers. Movement in the surficial and confined aquifers is affected by the tides (USGS 1991).

Surface water and associated sediment transport may play some role in contaminant migration in that surface runoff, particularly after intense storms, may carry dissolved and suspended contaminants from the contaminated areas into the marshes and estuaries. Surface water percolating through and leaching contaminated soils may be a major pathway by which contaminants move down into the groundwater, especially for metals and VOCs. Any contaminants that may have been present in the past in sufficient quantities to exist as free liquid in the soil would be expected to migrate down, independent of the presence of water. 
Because of the generally humid conditions in the J-Field study area, wind transport of contaminated soil in areas with a good vegetative cover is expected to be minor. Diffusion of contaminated soil gas into the atmosphere and direct volatilization of contaminants from the soil are also expected to be minor release mechanisms. However, because portions of the TBP AOC are unvegetated or are sparsely covered with stressed vegetation, the air pathway may be significant and will be investigated.

\subsubsection{White Phosphorus Burning Pits}

\subsubsection{Types of Waste Present}

The WPP area was used for the disposal of WP, PWP, and other related chemicals. It is also possible that riot control agents such as CN and TRCLE were disposed of in the WPP (Nemeth 1989).

\subsubsection{Types of Contaminants Present}

The first phase of the USGS hydrological assessment was conducted to select locations for monitoring wells at the TBP and WPP. It was assumed that the pits and the open burning grounds around them are the primary sources of contamination. The following subsections discuss the findings relative to the nature and extent of contamination in the WPP area.

\section{Soil Gas}

During Phase I of the hydrological assessment, the USGS sampled 35 locations around the WPP for soil-gas concentrations of TRCLE, TCLEE, combined hydrocarbons, and simple aromatics. The highest relative flux values of contamination were found north of the pits and to the west along the shore of Gunpowder River. Isolated areas of contamination were found to the south.

\section{Soil}

In 1983, soil samples were collected from each of the four monitor well boreholes at the WPP (Figure 2.17). For each borehole, one sample was obtained as a composite of samples collected over 5-ft intervals. The samples were analyzed for metals, cyanide, phenols, total phosphorus, VOCs, pesticides, PCBs, and herbicides.

The only significant contamination found was lead, at $1,360 \mathrm{mg} / \mathrm{kg}$ in the sample from borehole JBP-4. Arsenic (10 mg/kg), barium (208 mg/kg), and possibly cadmium $(1.33 \mathrm{mg} / \mathrm{kg}$ ) were found in the same sample. No VOCs were found in any of the samples at 


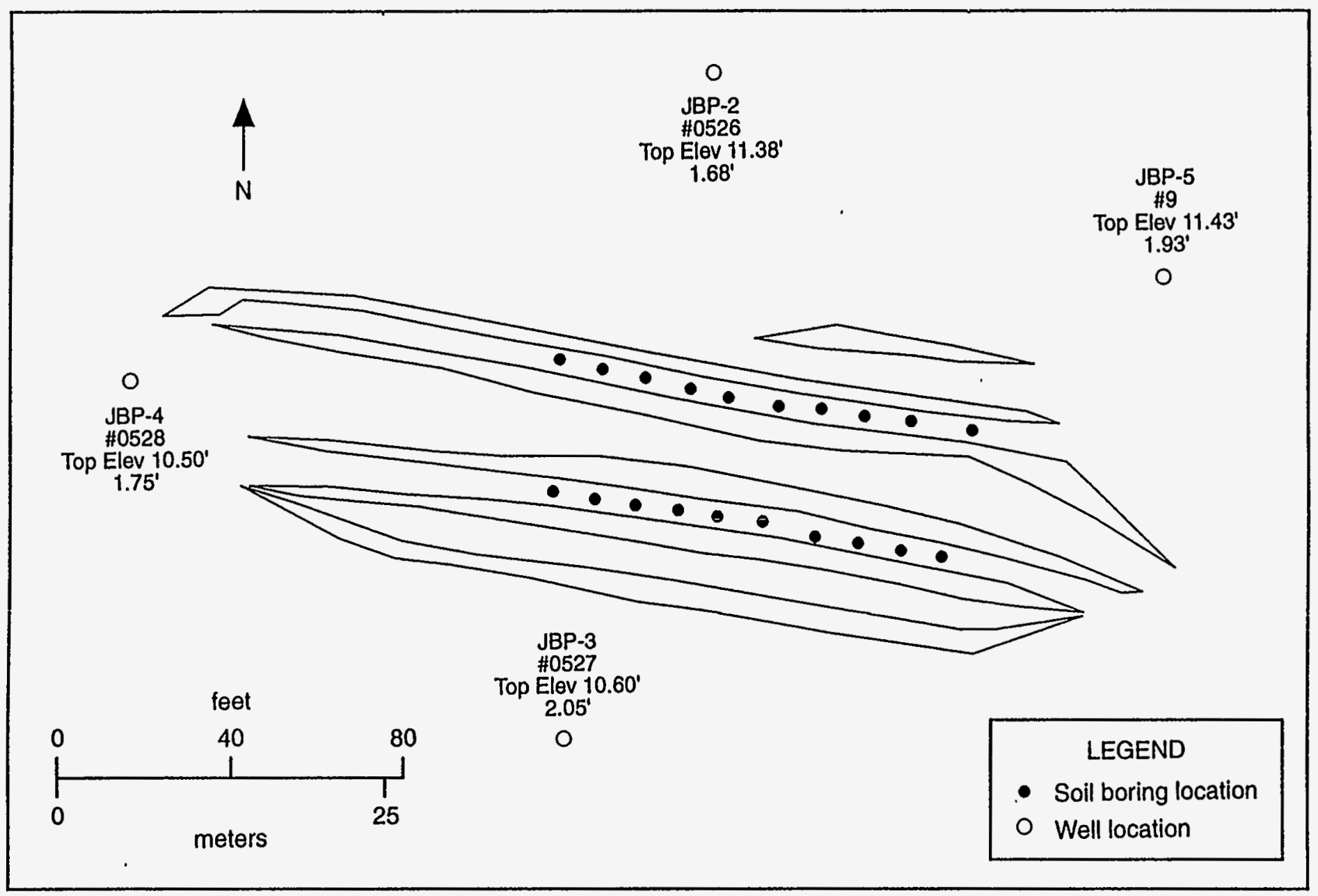

FIGURE 2.17 Locations of Soil Borings at the White Phosphorus Pits (Source: Adapted from Princeton Aqua Science 1984) 
a detection limit of $5 \mu \mathrm{g} / \mathrm{kg}$. Cyanide was not found at a detection limit of $20 \mu \mathrm{g} / \mathrm{kg}$. Samples from the other boreholes showed essentially no contamination (Princeton Aqua Science 1984). One composite sample was collected from each of the two main pits in the WPP AOC. The samples from the pits, along with background samples, were analyzed for several chemical parameters (Table 2.13). The results show significant levels of lead (up to 2,960 mg/kg) and zinc (up to $2,720 \mathrm{mg} / \mathrm{kg}$ ) in each sample. High concentrations of petroleum hydrocarbons (up to $5,800 \mathrm{mg} / \mathrm{kg}$ ) were also detected. The elevated levels of petroleum hydrocarbons in the background samples $(62 \mathrm{mg} / \mathrm{kg}$ ) indicate that these samples were collected at contaminated locations. Elevated levels of phosphorus (up to $1,573 \mathrm{mg} / \mathrm{kg}$ ) were also detected in the WPP samples.

As part of the 1986 RFA (Nemeth 1989), surface soil samples were collected at two locations (J31 and J32) in and around the WPP. Figure 2.18 shows the sampling locations. The samples were analyzed for metals, extractable metals, and explosives-related compounds. The results, as summarized in Table 2.14, show that the surface soil in and around the WPP contained elevated levels of metals, especially lead (up to $255 \mathrm{mg} / \mathrm{kg}$ ), chromium (up to $28.9 \mathrm{mg} / \mathrm{kg}$ ), cadmium (up to $2.40 \mathrm{mg} / \mathrm{kg}$ ), and barium (up to $149 \mathrm{mg} / \mathrm{kg}$ ). Neither of the two samples exceeded the RCRA EP limits for metals.

The USGS collected soil samples (at approximately 1-ft depths) from 36 sites in J-Field, including the WPP area. The samples were analyzed for indicator parameters, metals, VOCs, semivolatile compounds, and explosives (Hughes 1992). The results are presented in Table 2.15. Levels of metals were fairly low, except that at location 1 (just east of the pits) the concentration of zinc was $942 \mathrm{mg} / \mathrm{kg}$. No VOCs were detected.

Soil samples were also collected in the WPP area by Weston in October 1992. Samples were collected at depths of 2 and $4 \mathrm{ft}$ in the pits and at depths of 3 in. and $1 \mathrm{ft}$ in the marshes and pushout areas. Table 2.16 summarizes the analytic results for parameters detected in some of these samples.

\section{Surface Water}

Surface water samples (J37 and J38) were collected from the WPP area as part of the 1986 RFA (Nemeth 1989). Sampling locations are shown in Figure 2.18. Samples were analyzed for metals, explosives-related compounds, inorganic compounds, gross alpha and beta, VOCs, BNAs, pesticides, and PCBs. The results are summarized in Table 2.17 for locations J37 and J38.

The surface water contained some lead contamination. Sulfate and total dissolved solids (TDS) were slightly elevated in the WPP surface water, and gross alpha was also slightly elevated. None of the values for the other radioactive parameters was indicative of contamination. 
TABLE 2.13 Concentrations of Chemical Parameters in Soil from the White Phosphorus Pits at J-Field

\begin{tabular}{|c|c|c|c|}
\hline \multirow[b]{2}{*}{ Parameter $^{\mathbf{a}}$} & \multicolumn{3}{|c|}{ Concentration $^{\mathrm{b}}(\mathrm{mg} / \mathrm{kg}$, unless noted) } \\
\hline & Background $^{\mathrm{c}}$ & Pit $1^{\mathrm{d}}$ & Pit $2^{d}$ \\
\hline Arsenic & 1.46 & 2.93 & 0.915 \\
\hline Barium & 247 & 939 & 525 \\
\hline Cadmium & 0.519 & 6.70 & 2.74 \\
\hline Chromium & 34.3 & 203 & 183 \\
\hline Iron & 14,800 & 18,100 & 17,900 \\
\hline Lead & 889 & 2,960 & 1,310 \\
\hline Manganese & 267 & 260 & 197 \\
\hline Mercury & 0.042 & 0.037 & 0.065 \\
\hline Potassium & 2,420 & 2,260 & 2,520 \\
\hline Zinc & 45.4 & 2,530 & 2,720 \\
\hline $\mathrm{pH}$ (standard units) & 6.9 & 7.7 & 6.8 \\
\hline Nitrate & 202 & 498 & 136 \\
\hline Total phosphorus & 26 & 220 & 1,573 \\
\hline Cyanide & $<0.5$ & $<0.5$ & 0.77 \\
\hline Petroleum hydrocarbons & 62 & 2,260 & 5,800 \\
\hline Phenols & $<0.130$ & $<0.134$ & 0.636 \\
\hline \multicolumn{4}{|l|}{ Aromatics } \\
\hline Toluene $(\mu \mathrm{gg} / \mathrm{kg})$ & 45.8 & 75.6 & 27.4 \\
\hline Ethylbenzene ( $\mu \mathrm{g} / \mathrm{kg})$ & $<20$ & $<20$ & 51.6 \\
\hline
\end{tabular}

a Table lists parameters detected in at least one sample. Parameters measured but not detected are other aromatics $(<20 \mu \mathrm{g} / \mathrm{kg})$, VOCs $(<10 \mu \mathrm{g} / \mathrm{kg})$, herbicides $(<10 \mu \mathrm{g} / \mathrm{kg})$, pesticides $(<20 \mu \mathrm{g} / \mathrm{kg})$, and PCBs $(<10,000 \mu \mathrm{g} / \mathrm{kg})$.

b Results are based on composite soil samples taken in January 1983.

c Locations of background samples not given.

d Based on available information, it is inferred that Pit 1 is the northern pit and Pit 2 is the southern pit.

Source: Adapted from Princeton Aqua Science (1984). 


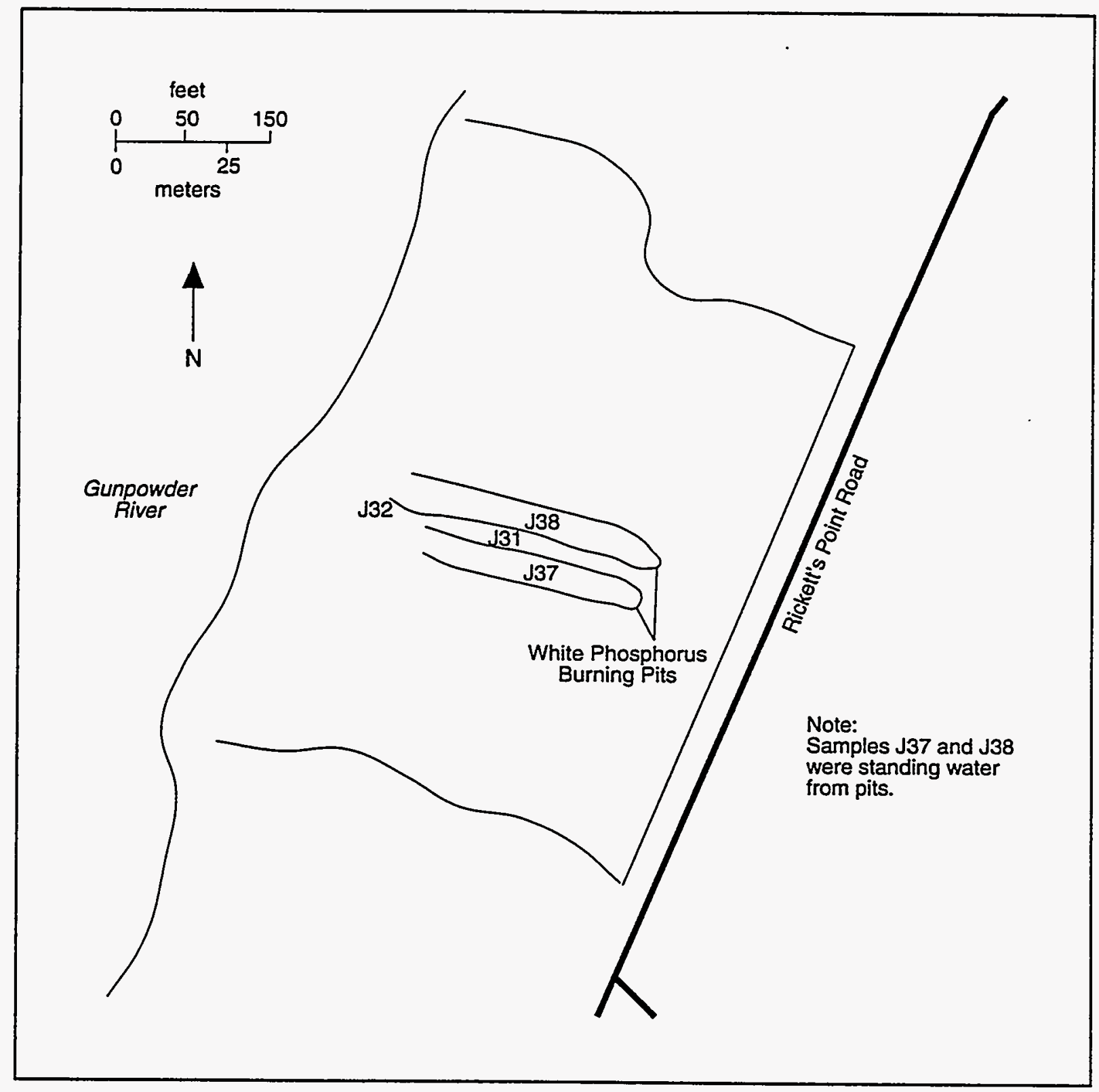

FIGURE 2.18 Locations of Surface Soil (J31 and J32) and Surface Water Samples (J37 and J38) in the White Phosphorus Pits Area (Source: Adapted from Hughes 1993) 
Surface water samples were collected by the USGS at low tide close to the J-Field shore in the Gunpowder River (four locations near the WPP). One sample was collected onshore in a drainage ditch. Locations are shown in Figure 2.13. Filtered and unfiltered samples were analyzed for water quality parameters, metals, and a few organic compounds. A sample taken at location 3 had nitrate concentrations of $380 \mu \mathrm{g} / \mathrm{L}$. The metals data showed low concentrations of lead (ND to $28 \mu \mathrm{g} / \mathrm{L}$ ) and zinc (50 to $133 \mu \mathrm{g} / \mathrm{L}$ ) at locations 1 to 4 . Mercury and nickel concentrations were slightly elevated at location 1 ( 0.54 and $33.7 \mu \mathrm{g} / \mathrm{L}$, respectively). No evidence was found of arsenic, barium, or chromium contamination. Comparison of data for filtered and unfiltered samples indicates that the slightly elevated metals concen-trations may be associated with the suspended solids in the samples. This conclusion is based on the lower concentrations of metals in filtered samples for the few locations where both filtered and unfiltered data were obtained (Hughes 1993).

A few organic constituents (acetone, toluene, phenol, TOC, and TOX) were measured in samples from two locations. TOC and TOX were detected in the unfiltered samples only (4,000 and $21.6 \mu \mathrm{g} / \mathrm{L}$, respectively). Toluene was found only at location $1(3.05 \mu \mathrm{g} / \mathrm{L})$ (Hughes 1993).

In general, the nearshore surface water samples collected to date show little contamination. What contamination there is appears to be associated with the suspended solids. This suggests that the nearshore sediments may be contaminated. Additional data are needed to evaluate this situation. No data are available on concentrations of pollutants in surface water or sediments in the marshes on J-Field.

\section{Groundwater}

Three monitoring wells (designated TH) were installed at the WPP in 1977 (Figure 2.15) as part of an environmental contamination survey conducted by USATHAMA (Nemeth 1989). The depth of the wells ranged from 20 to $25 \mathrm{ft}$. The wells were screened in the surficial aquifer (Sonntag 1991). Water samples collected from the wells in 1977 were analyzed for metals, indicator chemicals, WP, mustard degradation products, cholinesterase inhibitors, BNAs, and VOCs. 


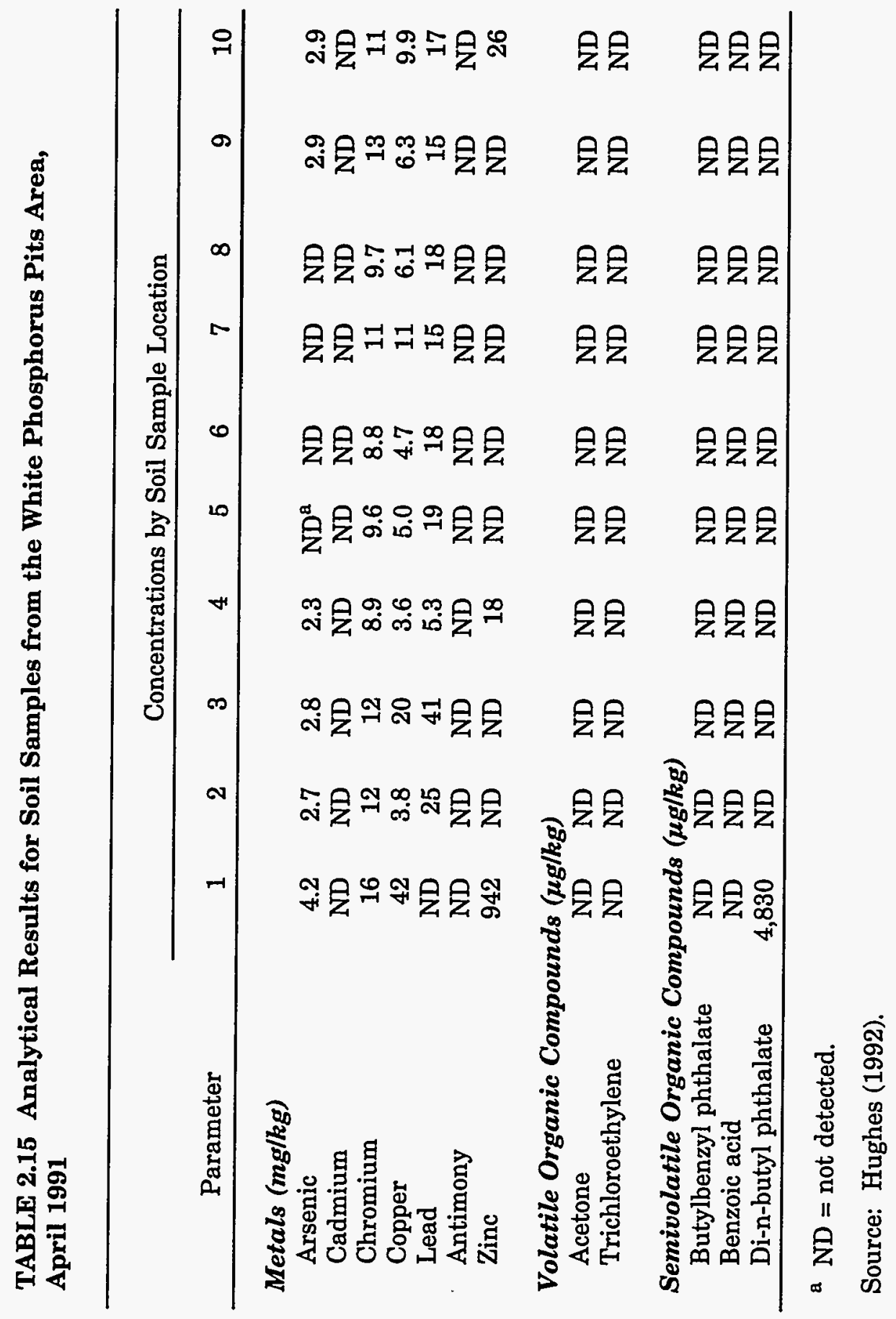


TABLE 2.16 Analytical Results for TCL and TAL Analytes in Selected Soil Samples from the White Phosphorus Pits, 1992 $^{\mathrm{a}}$

\begin{tabular}{|c|c|c|c|c|c|c|}
\hline \multirow[b]{2}{*}{ Parameter } & \multicolumn{6}{|c|}{ Concentrations by Soil Sample Location } \\
\hline & JWP1-E $\left(2^{\prime}\right)^{\mathrm{b}}$ & JWP1-E(4') & JWP2-E(2') & JWP2-E(4) & JWPM-A(3") & JWPM-A(1') \\
\hline \multicolumn{7}{|c|}{ Volatile Organic Compounds (ug/kg) } \\
\hline Methylene chloride & $\mathrm{ND}^{\mathrm{c}}$ & ND & 9.53 & 15.2 & 13.4 & $\mathrm{ND}$ \\
\hline Acetone & 494 & 156 & 165 & 38.9 & 185 & 21.5 \\
\hline Toluene & ND & ND & ND & ND & ND & ND \\
\hline Xylenes & ND & 16.6 & ND & ND & 11.2 & 9.17 \\
\hline \multicolumn{7}{|l|}{ PCBs ( $\mu \mathrm{g} / \mathrm{kg})$} \\
\hline Aroclor 1254 & ND & ND & ND & ND & ND & ND \\
\hline Aroclor 1260 & ND & ND & ND & ND & ND & ND \\
\hline \multicolumn{7}{|l|}{ TAL Analytes (mg/kg) } \\
\hline Antimony & ND & ND & ND & ND & 5.92 & ND \\
\hline Arsenic & 3.22 & 2.24 & 2.82 & ND & 4.20 & 2.46 \\
\hline Beryllium & 0.279 & 0.796 & 0.520 & ND & 0.318 & 0.335 \\
\hline Cadmium & ND & 0.626 & $\mathrm{ND}$ & ND & 2.02 & ND \\
\hline Chromium & 11.6 & 12.8 & 16.7 & 4.93 & 15.8 & 7.53 \\
\hline Cobalt & ND & ND & ND & ND & ND & ND \\
\hline Copper & 10.5 & 8.63 & 8.40 & ND & 59.4 & 11.0 \\
\hline Lead & 8.37 & 8.87 & 6.46 & 4.89 & 209 & 44.3 \\
\hline Zinc & 24.0 & 62.5 & 13.0 & 19.7 & 284 & 37.9 \\
\hline Nickel & ND & 13.7 & ND & 6.18 & ND & ND \\
\hline
\end{tabular}


TABLE 2.16 (Cont.)

\begin{tabular}{|c|c|c|c|c|c|c|}
\hline \multirow[b]{2}{*}{ Parameter } & \multicolumn{6}{|c|}{ Concentrations by Soil Sample Location } \\
\hline & JWPM-C(3") & JWPM-C(1') & JWPP-A(3") & JWPP-A(1') & JWPP-C(3") & JWPP-C(1') \\
\hline \multicolumn{7}{|c|}{ Volatile Organic Compounds ( $\mu \mathrm{g} / \mathrm{kg}$ ) } \\
\hline Methylene chloride & 10.8 & 5.83 & 17.0 & 7.51 & 9.29 & 8.35 \\
\hline Acetone & 16.1 & 45.0 & ND & 252 & ND & 178 \\
\hline Toluene & 7.42 & ND & ND & ND & ND & 6.54 \\
\hline Xylenes & 18.4 & ND & ND & ND & ND & 11.8 \\
\hline \multicolumn{7}{|l|}{ PCBs ( $\mu g / k g)$} \\
\hline Aroclor 1254 & ND & ND & ND & ND & 323 & ND \\
\hline Aroclor 1260 & 215 & ND & ND & ND & ND & ND \\
\hline \multicolumn{7}{|l|}{ TAL Analytes (mg/kg) } \\
\hline Antimony & ND & ND & ND & ND & 10.2 & ND \\
\hline Arsenic & 4.00 & 1.96 & 4.48 & 2.60 & 3.29 & 3.55 \\
\hline Beryllium & 0.239 & 0.182 & 0.254 & 0.218 & 0.267 & 0.308 \\
\hline Cadmium & 2.11 & ND & ND & ND & 1.62 & 0.576 \\
\hline Chromium & 20.8 & 8.37 & 12.4 & 10.6 & 21.9 & 9.83 \\
\hline Cobalt & ND & ND & $\mathrm{ND}$ & ND & ND & $\mathrm{ND}$ \\
\hline Copper & 111 & ND & 10.4 & ND & 109 & 19.8 \\
\hline Lead & 556 & 7.29 & 23.2 & 25.0 & 235 & 156 \\
\hline Zinc & 15.2 & 7.57 & 109 & 34.9 & 651 & 257 \\
\hline Nickel & 1,080 & 24.6 & 8.27 & 8.18 & 9.65 & 9.47 \\
\hline
\end{tabular}

a Only detected analytes are reported; for samples with duplicate analyses, the higher value is reported.

b Sample depth shown in parentheses.

c ND = not detected.

Source: Mazelon (1993). 
TABLE 2.17 Analytical Results for Surface Water Samples from the White Phosphorus Pits Area, 1986

\begin{tabular}{lcc}
\hline & \multicolumn{2}{c}{ Location } \\
\cline { 2 - 3 } \multicolumn{1}{c}{ Parameter } & $\mathrm{J} 37$ & $\mathrm{~J} 38$ \\
\hline Dissolved Metals $(\boldsymbol{\mu g} / \mathrm{L})$ & & \\
Cadmium & $<1.0$ & 3.0 \\
Lead & 6.0 & 44 \\
Mercury & $<0.20$ & $<0.20$ \\
& & \\
Inorganic Compounds ( $\boldsymbol{\mu g} / L)$ & \\
Nitrate and nitrite as N & $<30$ & 200 \\
Sulfate & 160,000 & 15,000 \\
Chloride & 5,000 & 3,000 \\
Total dissolved solids & 388,000 & 114,000 \\
& & \\
Radioactivity (pCi/L) & & \\
Gross alpha & 2.8 & 4.2 \\
Gross beta & 8.0 & 8.7 \\
\hline
\end{tabular}

Source: Nemeth (1989).

Low levels of organic contamination were found in all wells. A mustard degradation product, 1,3-dithiane, was found at a concentration of $6 \mu \mathrm{g} / \mathrm{L}$ in well TH1 near the WPP. Aliphatic and aromatic organic compounds were found at levels up to $200 \mu \mathrm{g} / \mathrm{L}$ in most well samples. Organic compounds introduced by the well construction procedure or possible sample contamination were found at higher concentrations (e.g., tetrahydrofuran up to $8,000 \mu \mathrm{g} / \mathrm{L})$.

Four additional wells were installed around the WPP (wells P5-P8 in Figure 2.15) as part of a munitions disposal study (Princeton Aqua Science 1984). The wells were 17-20 $\mathrm{ft}$ deep and were screened with 15-ft-long screens in the surficial aquifer (Sonntag 1991). Samples collected from the wells in 1983 were analyzed for metals, nitrate, TOX, TOC, radioactivity, some pesticides and herbicides, and secondary drinking water contaminants. Analyses indicated no major concentrations of metals, pesticides, or herbicides.

Samples collected from these four wells in 1986 as part of an RFA (Nemeth 1989) were analyzed for metals, explosives-related compounds, indicator parameters, radioactivity, thiodiglycol, VOCs, BNAs, pesticides, and PCBs. Sulfate, TDS, and TRCLE were the only parameters that showed any elevated concentrations.

Twelve additional monitoring wells were installed at the WPP in late 1988 and 1989 by the USGS (Sonntag 1991; Hughes 1993). The wells were installed as three-well nests at four different locations (Figure 2.15). At each site, the three wells were screened in the 
confined aquifer, the leaky confined unit, and the surficial aquifer of the Talbot Formation. The groundwater samples collected from the nested wells were analyzed for metals, other inorganic parameters, VOCs, and semivolatile organic compounds. Some analyses were performed for organosulfur, explosives-related, and radioactive compounds. Wells were selected for these analyses on the basis of their proximity to potential disposal areas for these materials (USGS 1991).

Potassium concentrations detected in the samples varied considerably, with most ranging from ND to $10 \mu \mathrm{g} / \mathrm{L}$. All of the elevated values (above $50 \mu \mathrm{g} / \mathrm{L}$ ) occurred in the leaky confined unit or the confined aquifer. Movement of sea water into the groundwater does not appear to be the source of the potassium, because wells with elevated potassium concentrations did not have elevated chloride concentrations.

Low levels of VOC contamination were detected in the WPP. Only one well, P8, showed contamination by TRCLE $(40 \mu \mathrm{g} / \mathrm{L})$. Some contamination by other VOCs was detected in wells P7 and JF10-2. (Acetone is excluded because of the possibility that its presence is a result of laboratory QC procedures.)

\subsubsection{Potential Pathways of Contaminant Migration}

Existing data indicate that the main pathway of contaminant migration at the WPP AOC is movement through the vadose zone down into the groundwater and then transport by the groundwater.

The direction of groundwater movement in the Talbot aquifers appears to be away from the WPP AOC toward the Gunpowder River. However, the lateral gradients in the lower aquifers are quite small (USGS 1991). The vertical movement of groundwater appears to be down through the aquifers; however, offshore there may be upward flow from each of the three Talbot aquifers into the Gunpowder and Bush rivers. Movement in the surficial and confined aquifers is affected by the tides (USGS 1991).

Surface water and associated sediment transport may play some role in contaminant migration in that surface runoff, particularly after intense storms, may carry dissolved and suspended contaminants from the contaminated areas into the marshes and estuaries. Lateral contaminant migration by surface water is expected to be minor (Sonntag 1991). However, in the past, the surface water pathway may have been more significant because the pits were operated to allow drainage to flow to the Gunpowder River (Weston 1992). Surface water percolating through and leaching contaminated soils may be a major pathway by which contaminants, especially metals and VOCs, move down into the groundwater. Any contaminants that may have been present in the past in sufficient amounts to exist as free liquid in the soil would be expected to migrate downward, independent of the presence of water.

Because of the generally humid conditions in the J-Field study area, wind transport of contaminated soil in areas with a good vegetative cover is expected to be minor. Diffusion 
of contaminated soil gas into the atmosphere and direct volatilization of contaminants from the soil are also expected to be minor release mechanisms. However, because portions of the WPP AOC are unvegetated or are sparsely covered with stressed vegetation, and because at least part of the WPP AOC is expected to be used for OB/OD, the air pathway may be significant and will be investigated.

\subsubsection{Riot Control Burning Pit}

\subsubsection{Types of Waste Present}

The RCP area was used for burning of riot control agents and disposing of munitions filled with riot control agents and of materials contaminated with these chemicals. The primary riot control chemicals disposed of in the burning pit were tear agents (CS and possibly $\mathrm{CN}$ ) and items contaminated with those agents.

\subsubsection{Types of Contaminants Present}

\section{Soil Gas}

Soil-gas sampling and analysis were conducted during Phase I of the USGS hydrological assessment. Soil-gas samples collected from 12 locations on a 100-ft grid around the RCP were analyzed for TRCLE, TCLEE, alkanes, combined hydrocarbons, and simple aromatics. Relative flux values indicated contamination by chlorinated solvents at areas north and south of the pits. Contamination by phthalates and heavy aromatic compounds appeared to be more extensive, with phthalates showing elevated contamination along Rickett's Point Road and at one location south of the pit. The highest measured flux value for aromatic compounds was at a location south of the pit. Figure 2.19 shows the relative flux contours for heavy aromatics at the pit.

\section{Soil}

A soil sample was collected immediately northeast of the disposal trench during the 1986 RFA (Nemeth 1989). That sample contained a significant amount of ash and other residue from burning operations; analysis showed slightly elevated levels of total cadmium, chromium, lead, and silver, and very low levels of polyaromatic hydrocarbons (PAHs).

Soil samples were collected by the USGS at 36 sites at J-Field, including the RCP area (locations 16 through 20 in Figure 2.11). The samples were collected at 1-ft depths and were analyzed for indicator parameters, metals, VOCs, semivolatile compounds, and explosives-related compounds (Hughes 1992). The results of the analyses are presented in Table 2.18. Soil samples showed some metals contamination, especially at locations 16,17 , 


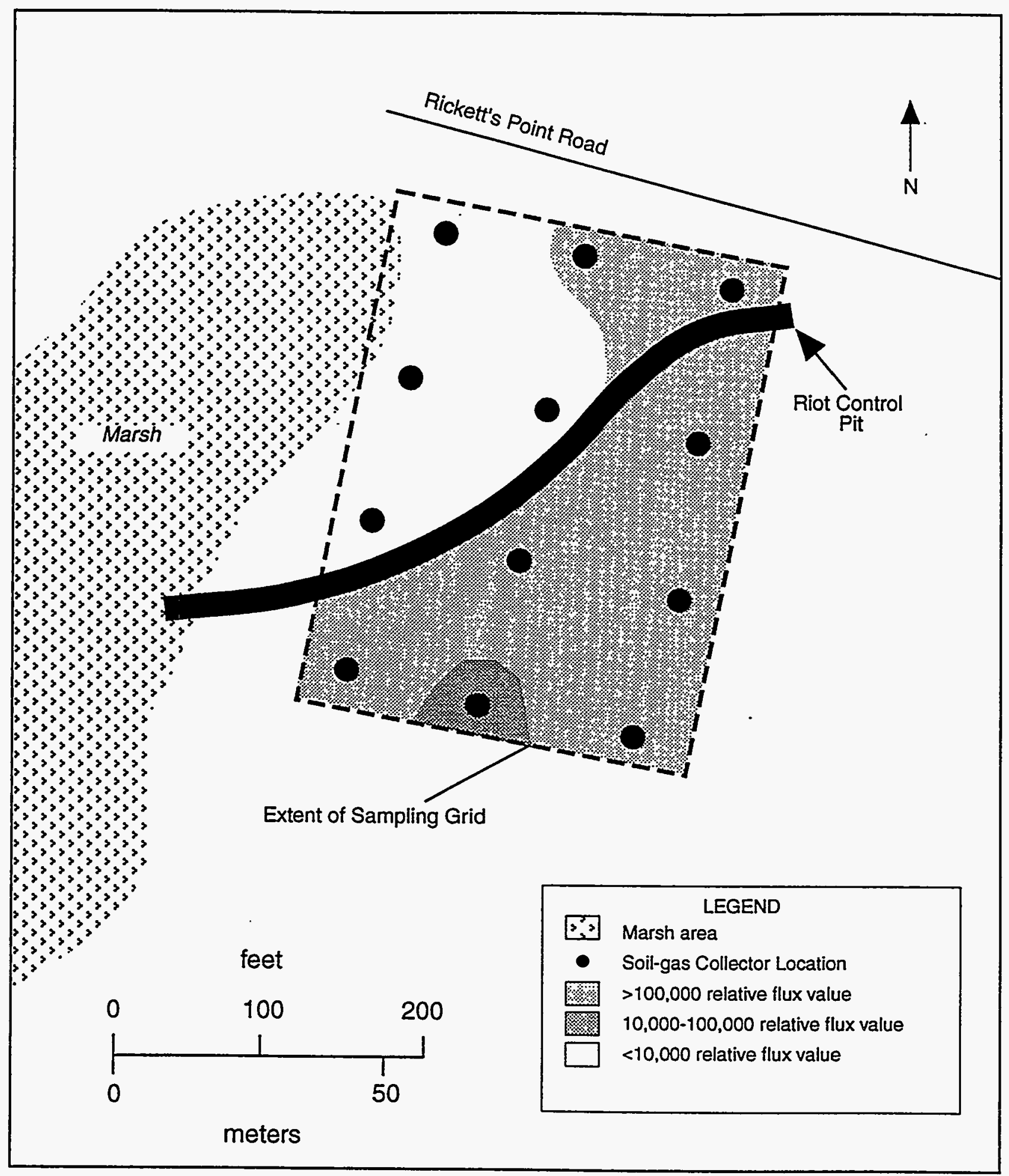

FIGURE 2.19 Relative Flux Contours of Heavy Aromatics at the Riot Control Burning Pit (Source: Adapted from Hughes 1993) 
TABLE 2.18 Analytical Results for Soil Samples from the Riot Control Burning Pit Area, April 1991

\begin{tabular}{|c|c|c|c|c|c|c|c|}
\hline \multirow[b]{2}{*}{ Parameter } & \multicolumn{7}{|c|}{ Concentration by Soil Sample Location } \\
\hline & 16 & 17 & 18 & 19 & 20 & 21 & 22 \\
\hline \multicolumn{8}{|l|}{ Metals (mg/kg) } \\
\hline Arsenic & 4.4 & 3.8 & 3.4 & 2.9 & 3.7 & 3.3 & $N D^{a}$ \\
\hline Cadmium & ND & ND & ND & $\mathrm{ND}$ & ND & ND & ND \\
\hline Chromium & 11 & 8.6 & 8.7 & 7.5 & 11 & 8.8 & 7.4 \\
\hline Copper & 9.5 & 10 & 9.5 & 5.4 & 7.0 & 7.2 & 15 \\
\hline Lead & 68 & 41 & 34 & 2.1 & 41 & 1.7 & 22 \\
\hline Antimony & ND & ND & ND & ND & ND & ND & ND \\
\hline Zinc & 158 & ND & ND & $\mathrm{ND}$ & ND & ND & ND \\
\hline \multicolumn{8}{|c|}{ Volatile Organic Compounds ( $\mu \mathrm{g} / \mathrm{kg}$ ) } \\
\hline Acetone & 7.27 & 29.6 & 9.01 & 6.47 & 10.2 & 9.51 & 2.45 \\
\hline Trichloroethylene & ND & ND & ND & $\mathrm{ND}$ & ND & ND & $\mathrm{ND}$ \\
\hline \multicolumn{8}{|c|}{ Semivolatile Organic Compounds ( $\mu g / k g$ ) } \\
\hline Butylbenzl phthalate & ND & $\mathrm{ND}$ & 528 & ND & ND & ND & 3,700 \\
\hline Benzoic acid & 3,400 & 12,000 & ND & 1,800 & 949 & 654 & 3,700 \\
\hline
\end{tabular}

and 18 north of the pit, where lead concentrations ranged from 34 to $68 \mathrm{mg} / \mathrm{kg}$. Zinc was found at $158 \mathrm{mg} / \mathrm{kg}$ at location 16. Organic compounds (acetone, butylbenzyl phthalate, and benzoic acid) were also detected in some samples.

Soil samples were also collected in the RCP area by Weston in October 1992 (Figure 2.20). The samples were collected at 3-in., 2-ft, and 4-ft depths in the pit and at 3-in. and 1-ft depths in the marshes and pushout areas. Tables 2.19 and 2.20 summarize the analytic results for parameters detected in some of these samples. The data indicate that several areas are contaminated with metals, mainly at the surface (within 3 in. to $2 \mathrm{ft}$ ). The highest concentrations of lead were found in the center of the RCP (up to $339 \mathrm{mg} / \mathrm{kg}$ at $3 \mathrm{in}$.). Lead concentrations ranged from 31 to $90 \mathrm{mg} / \mathrm{kg}$ at the ends of the pit, in the marshes, and in the pushout areas. Other metals detected include beryllium, up to $0.451 \mathrm{mg} / \mathrm{kg}$ in the marsh east of the RCP; chromium, up to $106 \mathrm{mg} / \mathrm{kg}$ at the eastern end of the RCP; copper, up to $742 \mathrm{mg} / \mathrm{kg}$ at the eastern end of the RCP; and zinc, up to $742 \mathrm{mg} / \mathrm{kg}$ in the center of the RCP. Organic compounds were also detected, including benzoic acid, chlorobenzene, di-nbutyl phthalate, acetone, methylene chloride, styrene, toluene, xylene, and pesticides. PCBs were not detected. 


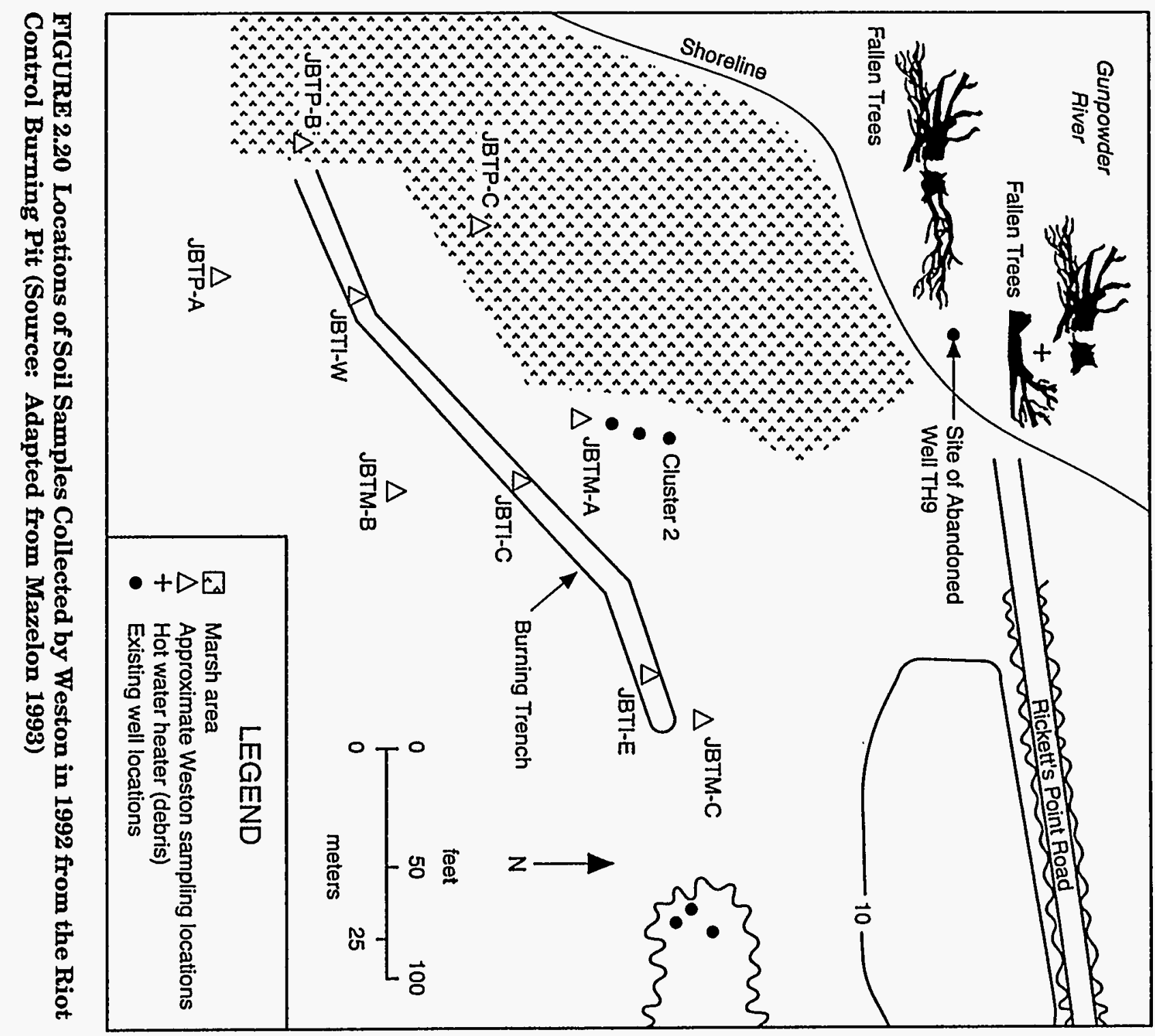

ปั่ 
TABLE 2.19 Analytical Results for TCL Analytes in Selected Soil Samples from the Riot Control Burning Pit Area, 1992 ${ }^{\mathrm{a}}$

\begin{tabular}{|c|c|c|c|c|c|c|}
\hline \multirow[b]{2}{*}{ TCL Analyte } & \multicolumn{6}{|c|}{ Concentrations $(\mu \mathrm{g} / \mathrm{kg})$ by Soil Sample Location } \\
\hline & JBT1-E $\left(3^{\prime \prime}\right)^{b}$ & JBT1-E(2) & JBT1-E(4) & JBP1-W(3") & JBT1-W(2) & JBT1-W(4) \\
\hline \multicolumn{7}{|l|}{ Volatile Organic Compounds } \\
\hline Acetone & 61.8 & 46.2 & 191 & 236 & 82.2 & 18.5 \\
\hline Benzene & $\mathrm{ND}^{\mathrm{c}}$ & ND & ND & ND & ND & ND \\
\hline Carbon disulfide & ND & ND & ND & ND & ND & ND \\
\hline Chloroform & ND & ND & ND & ND & ND & ND \\
\hline Chloroethane & ND & ND & ND & ND & ND & ND \\
\hline Chloromethane & 10.3 & 7.7 & 5.22 & 13.2 & 17.6 & 6.75 \\
\hline Styrene & ND & ND & ND & ND & ND & ND \\
\hline Toluene & ND & ND & ND & ND & ND & $\mathrm{ND}$ \\
\hline Xylenes & ND & ND & ND & ND & ND & ND \\
\hline \multicolumn{7}{|c|}{ Semivolatile Organic Compounds } \\
\hline 2-Methylnaphthalene & 52 & ND & ND & ND & ND & ND \\
\hline Benzoic acid & ND & ND & ND & 183 & 79.2 & 47.8 \\
\hline bis-(2-Chloromethyl) ether & ND & ND & ND & ND & ND & ND \\
\hline bis-(2-Ethylhexyl) phthalate & ND & ND & ND & ND & ND & ND \\
\hline Di-n-butyl phthalate & ND & ND & ND & 217 & 111 & 54.1 \\
\hline Fluoranthene & ND & ND & ND & ND & ND & ND \\
\hline Hexachlobenzene & ND & ND & ND & ND & ND & ND \\
\hline Pyrene & ND & ND & ND & ND & ND & ND \\
\hline \multicolumn{7}{|l|}{ Pesticides } \\
\hline $4,4^{\prime} \mathrm{DDD}$ & ND & ND & ND & ND & ND & ND \\
\hline $4,4^{\circ} \mathrm{DDE}$ & 2.22 & ND & ND & 10.6 & ND & ND \\
\hline $4,4^{-} \mathrm{DDT}$ & ND & $\mathrm{ND}$ & ND & ND & ND & ND \\
\hline \multicolumn{7}{|l|}{$P C B s$} \\
\hline Aroclor 1248 & ND & ND & ND & ND & ND & ND \\
\hline Aroclor 1254 & ND & ND & ND & ND & ND & ND \\
\hline
\end{tabular}


Concentrations $(\mu \mathrm{g} / \mathrm{kg})$ by Soil Sample Location

\begin{tabular}{|c|c|c|c|c|c|c|c|c|}
\hline TCL Analyte & JBTM-A(3") & JBTM-A(1) & JBTM-C(3") & JBTM-C(1) & JBTP-A(3") & JBTP-A(1) & JBTP-C(3") & JBTP-C(1') \\
\hline \multicolumn{9}{|l|}{ Volatile Organic Compounds } \\
\hline Acetone & 171 & 55.4 & 169 & 91 & 70.4 & 74.3 & ND & ND \\
\hline Benzene & ND & ND & ND & 2.46 & ND & ND & ND & $N D$ \\
\hline Carbon disulfide & $\mathrm{ND}$ & $\mathrm{ND}$ & ND & $\mathrm{ND}$ & 4.89 & ND & ND & ND \\
\hline Chloroform & $\mathrm{ND}$ & ND & ND & $\mathrm{ND}$ & ND & ND & 20.3 & ND \\
\hline Chloroethane & 12.2 & 2.72 & ND & ND & ND & ND & $\mathrm{ND}$ & ND \\
\hline Chloromethane & 10.2 & 5.75 & 5.87 & 9.75 & 12.2 & 5.69 & 5.69 & 3.26 \\
\hline Styrene & 8.57 & ND & ND & ND & ND & 18 & ND & $\mathrm{ND}$ \\
\hline Toluene & 42.3 & 16.2 & 7.9 & 1.77 & ND & 1.44 & ND & ND \\
\hline Xylenes & 159 & 77.2 & ND & ND & ND & ND & ND & ND \\
\hline \multicolumn{9}{|c|}{ Semivolatile Organic Compounds } \\
\hline 2-Methylnaphthalene & ND & ND & ND & ND & ND & ND & ND & ND \\
\hline Benzoic acid & 4,380 & 100 & ND & 63.6 & 840 & 336 & ND & 106 \\
\hline bis-(2-Chloromethyl) ether & 438 & ND & ND & ND & 64.5 & ND & 54 & ND \\
\hline bis-(2-Ethylhexyl) phthalate & ND & ND & ND & ND & ND & 41.5 & ND & ND \\
\hline Di-n-butyl phthalate & 126 & 53.5 & $\mathrm{ND}$ & ND & ND & ND & ND & 188 \\
\hline Fluoranthene & ND & ND & ND & ND & ND & ND & ND & ND \\
\hline Hexachlobenzene & ND & ND & $\mathrm{ND}$ & ND & ND & ND & ND & ND \\
\hline Pyrene & ND & ND & ND & ND & ND & $\mathrm{ND}$ & ND & ND \\
\hline \multicolumn{9}{|l|}{ Pesticides } \\
\hline $4,4^{\prime} \mathrm{DDD}$ & ND & ND & ND & ND & ND & ND & ND & ND \\
\hline $4,4^{\circ} \mathrm{DDE}$ & 32.9 & ND & $\mathrm{ND}$ & 1.79 & 10.1 & ND & 4.69 & ND \\
\hline $4,4^{\prime} \mathrm{DDT}$ & 8.28 & ND & ND & ND & ND & ND & ND & ND \\
\hline \multicolumn{9}{|l|}{$P C B 8$} \\
\hline Aroclor 1248 & ND & ND & ND & ND & ND & ND & ND & ND \\
\hline Aroclor 1254 & ND & $\mathrm{ND}$ & ND & ND & ND & ND & ND & ND \\
\hline
\end{tabular}

a Only detected analytes are reported; for samples with duplicate analyses, the higher value is reported.

b Sample depth shown in parentheses.

c $\mathrm{ND}=$ not detected. 
TABLE 2.20 Analytical Results for TAL Analytes in Selected Soil Samples from the Riot Control Burning Pit Area, 1992

\begin{tabular}{|c|c|c|c|c|c|c|c|}
\hline \multirow{2}{*}{$\begin{array}{c}\text { TAL } \\
\text { Analyte }\end{array}$} & \multicolumn{7}{|c|}{ Concentration $(\mathrm{mg} / \mathrm{kg})$ by Soil Sample Location } \\
\hline & JBT1-E(3") & JBT1-E(2) & JBT1-E(4') & JBT1-W(3") & JBT1-W(2) & JBT1-W(4') & JBTM-A(3") \\
\hline Antimony & $\mathrm{ND}^{\mathrm{c}}$ & 5.31 & ND & ND & $\mathrm{ND}$ & ND & ND \\
\hline Arsenic & 4.96 & 4.27 & ND & ND & 2.94 & 1.84 & 2.77 \\
\hline Beryllium & 0.374 & 0.343 & ND & 0.355 & 0.362 & 0.278 & 0.555 \\
\hline Cadmium & 5.24 & 2.73 & $\mathrm{ND}$ & 0.907 & 0.690 & ND & 0.994 \\
\hline Chromium & 106 & 40 & 11.9 & 11.3 & 17.3 & 16.6 & 14.2 \\
\hline Cobalt & ND & ND & ND & ND & ND & ND & ND \\
\hline Copper & 742 & 262 & 116 & 23.2 & $\mathrm{ND}$ & 9.79 & 12.3 \\
\hline Lead & 1.14 & 49.2 & 10.9 & 60.5 & 8.98 & 8.92 & 57.1 \\
\hline Zinc & 281 & 139 & 45.6 & 119 & 17.2 & 14.6 & 46.6 \\
\hline Nickel & 40.2 & 23.2 & 9.89 & ND & 9.08 & 8.01 & 12.6 \\
\hline \multirow{2}{*}{$\begin{array}{c}\text { TAL } \\
\text { Analyte }\end{array}$} & \multicolumn{7}{|c|}{ Concentration $(\mathrm{mg} / \mathrm{kg})$ by Soil Sample Location } \\
\hline & JBTM-A(1') & JBTM-C(3") & JBTM-C(1') & JBTP-A(3") & JBTP-A(1') & JBTP-C(3") & JBTP-C(1') \\
\hline Antimony & $\mathrm{ND}^{\mathbf{c}}$ & ND & ND & ND & ND & $\mathrm{ND}$ & ND \\
\hline Arsenic & ND & 1.87 & 1.72 & ND & 2.18 & 2.28 & 1.81 \\
\hline Beryllium & 0.337 & 0.451 & 0.279 & 0.418 & 0.328 & $\mathrm{ND}$ & 0.745 \\
\hline Cadmium & 0.586 & 0.898 & 0.696 & 1.7 & 0.601 & ND & ND \\
\hline Chromium & 8.06 & 12.1 & 11.1 & 12.6 & 14.2 & 14.1 & 24.3 \\
\hline Cobalt & ND & $\mathrm{ND}$ & ND & ND & ND & ND & ND \\
\hline Copper & ND & 9.01 & ND & 8.98 & ND & 11.3 & 9.41 \\
\hline Lead & 5.97 & 52.2 & 7.61 & 33.2 & 7.23 & 41.8 & 9.13 \\
\hline Zinc & 5.02 & 58.9 & 6.77 & 22.2 & 11.3 & 39.4 & 36.3 \\
\hline Nickel & ND & 8.27 & 7.16 & 17.5 & $\mathrm{ND}$ & ND & 11.2 \\
\hline
\end{tabular}

a Only detected analytes are reported; for samples with duplicate analyses, the higher value is reported.

b Sample depth shown in parentheses.

c $\mathrm{ND}=$ not detected. 


\section{Surface Water}

Surface water samples were collected by the USGS at low tide close to the shore near the RCP area (locations 7-12 in Figure 2.13). Both filtered and unfiltered samples were analyzed for major water quality parameters, metals, and a few organic compounds. Nitrate concentrations from location 7 ranged from 200 to $400 \mu \mathrm{g} / \mathrm{L}$. Phenol, TOC, and TOX were also detected in the unfiltered sample from location $7(51.9,7,000$, and $20 \mu \mathrm{g} / \mathrm{L}$, respectively). As described in Section 2.3.1.2, the USGS and the EPA ERT sampled surface water and sediment from areas offshore of the RCP.

In general, the nearshore surface water quality data from the samples collected to date show essentially no contamination. What contamination there is appears to be associated with the suspended solids. This finding suggests that the nearshore sediments may be contaminated.

\section{Groundwater}

Two monitoring wells (TH9 and TH10 in Figure 2.15) were installed near the RCP area as part of the 1977 environmental contamination survey (Nemeth 1989). The depth of the wells ranged from 20 to $25 \mathrm{ft}$. The wells were screened in the surficial aquifer (Sonntag 1991). Water samples collected from the wells in 1977 were analyzed for metals, indicator chemicals, WP, mustard degradation products, cholinesterase inhibitors, BNAs, and VOCs. Only very low levels of organic contamination were detected. Because of the erosion of the shoreline west of the RCP, well TH9 was abandoned, and the shoreline was stabilized with gabion baskets and riprap.

Two monitoring well nests (JF1 and JF2 in Figure 2.15) were installed near the RCP in late 1988 and 1989 by the USGS (Sonntag 1991; Hughes 1993). At each site, the wells were screened in the confined aquifer, the leaky confined unit, and the surficial aquifer of the Talbot Formation. One monitoring well (well 143) was installed south of the RCP AOC in 1992.

Groundwater samples were analyzed for metals, VOCs, and semivolatile organic compounds during a 1990 sampling episode. Samples from wells JF22 and JF23 were analyzed for organosulfur and explosives-related compounds. None of these compounds was detected, but the results showed some contamination by fluoride in both wells. Cyanide was found in well JF22 at a concentration of $65.6 \mu \mathrm{g} / \mathrm{L}$. The VOC measurements for well JF13 showed the presence of benzene $(1,500 \mu \mathrm{g} / \mathrm{L})$ and methylisobutylketone $(640 \mu \mathrm{g} / \mathrm{L})$. Benzene was also detected at $800 \mu \mathrm{g} / \mathrm{L}$ in well JF13 during a 1992 sampling episode. No volatile organic compounds were detected in the newly installed well (143) (USGS 1992). 


\subsubsection{Potential Pathways of Contaminant Migration}

Existing data indicate that the main pathway of contaminant migration at the RCP AOC is movement through the vadose zone down into the groundwater and then transport by groundwater.

The direction of groundwater movement in the Talbot aquifers appears to be away from the RCP AOC toward the Gunpowder River and Chesapeake Bay. However, the lateral gradients in the lower aquifers are quite small (USGS 1991). Vertical movement of groundwater appears to be down through the aquifers. Offshore, there may be upward flow from each of the three Talbot aquifers into the Gunpowder and Bush rivers. Movement in the surface and confined aquifers is affected by the tides (USGS 1991).

Surface water and associated sediment transport may play some role in contaminant migration in that surface runoff, particularly after intense storms, may carry dissolved and suspended contaminants from the contaminated areas into the river and bay. Lateral contaminant migration by surface water is expected to be minor (Sonntag 1991). However, surface water percolating through and leaching contaminated soils may be a major pathway by which contaminants, especially metals and VOCs, move down into the groundwater. Any contaminants that may have been present in the past in sufficient amounts to exist as free liquid in the soil would be expected to migrate down, independent of the presence of water.

Because of the generally humid conditions in the J-Field study area, wind transport of contaminated soil in areas with a good vegetative cover is expected to be minor. Diffusion of contaminated soil gas into the atmosphere and direct volatilization of contaminants from the soil are also expected to be release mechanisms.

\subsubsection{South Beach Trench}

\subsubsection{Types of Waste Present}

No information is available concerning chemical or hazardous material disposal in the SBT. It is possible that the trench was originally used as a borrow pit to obtain soil for the demolition work on the South Beach of J-Field (Nemeth 1989). A review of aerial photographs reveals the presence of an additional trench, which is now filled in but visible, about $40 \mathrm{ft}$ west of current SBT. In the photographs, the western trench is oriented east-west and is about $300 \mathrm{ft}$ in length. Small drums are scattered in the woods near the western trench (U.S. Army 1965). 


\subsubsection{Types of Contaminants Present}

\section{Soil Gas}

Soil-gas samples have not been collected from this area.

\section{Soil}

Analysis of a single soil sample collected in the SBT area as part of an environmental survey in 1983 (Nemeth 1989) showed a low level of chlordane (53 $\mu \mathrm{g} / \mathrm{kg}$ ) and tentatively identified several other organic compounds. Two soil samples were collected by the USGS in the SBT area (locations 21 and 22 in Figure 2.11). The samples were collected at 1-ft depths and analyzed for indicator parameters, metals, VOCs, semivolatile compounds, and explosives-related compounds (Hughes 1992). The results indicate that metals are present in low concentrations: lead, ranging from 2 to $22 \mathrm{mg} / \mathrm{kg}$; copper, from 7 to $15 \mathrm{mg} / \mathrm{kg}$; and chromium, from 7 to $9 \mathrm{mg} / \mathrm{kg}$. Acetone was the only organic compound detected (ranging from 10 to $25 \mathrm{mg} / \mathrm{kg}$ ).

\section{Surface Water .}

Surface water samples have not been collected at the SBT.

\section{Groundwater}

A monitoring well (TH10 in Figure 2.15) was installed south of the trench during the 1977 environmental survey (Nemeth 1989). Water collected from this well was analyzed for extractable organic compounds; analyses showed the presence of hydrocarbons, dimethylnaphthalene, and N,N-dimethylformamide. This well was also sampled as part of the RFA, with analysis for VOCs, BNAs, pesticides, and PCBs. No contaminants were detected in the water at that time (Nemeth 1989).

The USGS sampled well TH10 in 1991 as part of the hydrological assessment, Phase I. The water was analyzed for metals, water quality parameters, major ions, VOCs, and explosives-related compounds. No contamination was detected. Samples collected in 1992 from wells JF1 and JF2 were analyzed for VOCs. Benzene concentrations ranged from 110 to $800 \mu \mathrm{g} / \mathrm{L}$ in the surficial aquifer. Low levels of acetone were also detected.

\subsubsection{Potential Pathways of Contaminant Migration}

The main pathway of contaminant migration at the South Beach Trench is believed to be movement through the vadose zone into the groundwater and then transport by the groundwater. 
The direction of groundwater movement in the Talbot aquifers appears to be away from the trench area toward the bay. However, the lateral gradients in the lower aquifers are quite small (USGS 1991). The vertical movement of groundwater appears to be down through the aquifers; however, offshore there may be upward flow from each of the three Talbot aquifers into the Gunpowder and Bush rivers. Movement in the surficial and confined aquifers is affected by the tides (USGS 1991).

Surface water and associated sediment transport may play some role in contaminant migration in that surface runoff, particularly after intense storms, may carry dissolved and suspended contaminants from contaminated soil down into the bay. Lateral contaminant migration by surface water is expected to be minor (Sonntag 1991). However, surface water percolating through and leaching contaminated soils may be a major pathway by which contaminants, especially metals and VOCs, move down into the groundwater. Any contaminants that may have been present in the past in sufficient amounts to exist as free liquid in the soil would be expected to migrate down independent of the presence of water.

Because of the generally humid conditions and the presence of a vegetative cover over the South Beach Trench, wind transport of contaminated soil is expected to be minor. Diffusion of contaminated soil gas into the atmosphere and direct volatilization of contaminants from the soil are also expected to be minor.

\subsubsection{South Beach Demolition Ground}

\subsubsection{Types of Waste Present}

The SBDG was used as a demolition site for HE during the 1960s and 1970s. Items were detonated either at the ground surface or buried several feet deep. Because of the high rates of erosion at J-Field, the SBDG is now offshore in the Chesapeake Bay (Hughes 1993). Its presence is marked only by the abundant fragments of munitions and pieces of metal that can be observed at low tide.

\subsubsection{Types of Contaminants Present}

\section{Soil Gas and Soil}

Soil-gas and soil sampling and analysis were not conducted because the area is now offshore.

\section{Surface Water}

Surface water samples were collected by the USGS in 1991 at low tide close to the SBDG shore (locations 12 and 13 in Figure 2.13). Both filtered and unfiltered samples were 
analyzed for major water quality parameters, metals, and a few organic compounds. Phenol, TOC, and TOX were detected in the unfiltered sample from location $13(9.6,4,000$, and $30.4 \mu \mathrm{g} / \mathrm{L}$, respectively).

As described in Section 2.3.1.2, the USGS and EPA ERT sampled surface water and sediment from the location of the SBDG. In general, the nearshore surface water data from the samples collected to date show essentially no contamination. What contamination that does exist appears to be associated with the suspended solids. This suggests that the nearshore sediments may be contaminated. Additional data are needed to evaluate the nearshore sediments.

\section{Groundwater}

Groundwater sampling and analysis were not performed because the area is now offshore and no wells are present in the immediate area.

\subsubsection{Potential Pathways of Contaminant Migration}

The main pathway of contaminant migration at the SBDG is expected to be by surface water, including wave action and tidal action. This conclusion is valid only for metals, because organic compounds most likely would have degraded in the bay. Because this area is currently under water, wind transport of contaminants is expected to be an insignificant migration pathway.

\subsubsection{Prototype Building}

\subsubsection{Types of Waste Present}

The PB area was believed to be used primarily for the storage of solid waste when disposal operations were active at J-Field. In addition, a review of aerial photographs suggests that there was a burning area about $200 \mathrm{ft}$ west of the $\mathrm{PB}$ and near the edge of the existing tree line. The southern boundary of the area is marked by piles of soil, while its northern edge is marked by tall reeds and shallow ponded water. A rusted drum and scrap metal have been found on the ground surface (U.S. Army 1965). Another suspect burning area is located northeast of the PB. No records were kept of the types or quantities of material stored or potentially burned at the $\mathrm{PB}$. 


\subsubsection{Types of Contaminants Present}

\section{Soil Gas}

Soil-gas sampling and analysis were not performed in this area.

\section{Soil}

As part of the 1986 RFA (Nemeth 1989), surface soil samples collected at several locations near the PB (Figure 2.10) were analyzed for metals, extractable metals, and explosives-related compounds. Composites of samples from different locations were analyzed for BNAs, pesticides, and PCBs.

Cadmium and lead were detected at concentrations of 16.6 and $1,622 \mathrm{mg} / \mathrm{kg}$ (respectively) near the southern side of the PB. Organic compounds were also present in the soil samples, but below measurable levels. A composite sample taken near the PB contained low concentrations of pesticides, including $1.0 \mathrm{mg} / \mathrm{kg}$ each of DDD, DDE, and DDT.

Soil samples were collected by the USGS in 1991 at 36 sites in J-Field, including the PB (locations 11 through 15 in Figure 2.11). The samples were collected at 1-ft depths and analyzed for indicator parameters, metals, VOCs, semivolatile compounds, and explosivesrelated compounds (Hughes 1992). The analyses showed that metals contamination is present at the site, especially at location 15, where lead was detected at $93.3 \mathrm{mg} / \mathrm{kg}$, chromium at $18.8 \mathrm{~m} / \mathrm{kg}$, copper at $47.5 \mathrm{mg} / \mathrm{kg}$, and zinc at $158 \mathrm{mg} / \mathrm{kg}$. Limited analyses for organic compounds were also conducted; no significant contamination was found.

\section{Surface Water}

As noted in Section 2.3.1.2, the USGS and EPA ERT sampled surface water and sediment offshore from the PB.

\section{Groundwater}

Three monitoring wells were installed in the area of the PB (wells TH5, TH6, and TH8 in Figure 2.15). Analysis of a water sample collected from TH5 during an environmental survey (Nemeth 1989) showed only compounds related to well construction. Minor amounts of hydrocarbons were detected in groundwater from TH8. The compounds 111TCE and dimethyl disulfide were detected in well TH6 (on the southern side of the PB).

An additional monitoring well nest, JF3, was installed near the PB by the USGS (Sonntag 1991; Hughes 1993). The well nest consists of three wells, screened in the confined aquifer, the leaky confined unit, and the surficial aquifer of the Talbot Formation (Figure 2.15). Groundwater samples were analyzed for metals, water quality parameters, 
VOCs, and semivolatile organic compounds. The results of VOC measurements on samples from well TH8 showed that benzene $(6.43 \mu \mathrm{g} / \mathrm{L})$ and methylisobutylketone $(120 \mu \mathrm{g} / \mathrm{L})$ contamination is present. However, no VOCs were detected in well TH8 or in wells JF3-1, JF3-2, and JF3-3 during a 1992 sampling episode (USGS 1992).

\subsubsection{Potential Pathways of Contaminant Migration}

The main pathway of contaminant migration at the PB is believed to be movement through the vadose zone into the groundwater and then transport by the groundwater.

The direction of groundwater movement in the Talbot aquifers appears to be away from the PB toward the Gunpowder River. However, the lateral gradients in the lower aquifers are quite small (USGS 1991). The vertical movement of groundwater appears to be down through the aquifers; however, offshore there may be upward flow from each of the three Talbot aquifers and into the Gunpowder and Bush rivers. Movement in the surface and confined aquifers is affected by the tides (USGS 1991).

Surface water and associated sediment transport may play some role in contaminant migration in that surface runoff, particularly after intense storms, may also carry dissolved and suspended contaminants from the soil toward the river. Lateral contaminant migration by surface water is expected to be minor (Sonntag 1991). However, surface water percolating through and leaching contaminated soils may be a major pathway by which contaminants, especially metals and VOCs, move down into the groundwater. Any contaminants that may have been present in the past in sufficient amounts to exist as free liquid in the soil would be expected to migrate down, independent of the presence of water.

Because of the generally humid conditions in the J-Field study area, wind transport of contaminated soil in areas with a good vegetative cover is expected to be a minor migration pathway. Diffusion of contaminated soil gas into the atmosphere and direct volatilization of contaminants from the soil are also expected to be minor. However, because portions of the PB area are unvegetated or are sparsely covered with stressed vegetation, and because at least part of the area is expected to be used for open burning, the air pathway may be significant.

\subsubsection{Robins Point Tower Site}

\subsubsection{Types of Waste Present}

Robins Point was a launch and observation site for rocket testing programs conducted in the J-Field area. No information has been uncovered to indicate that solid or hazardous waste was generated or handled at this site. However, Nemeth (1989) found records indicating that radioactive contaminated wood may have been burned at this site. 


\subsubsection{Types of Contaminants Present}

\section{Soil Gas}

Soil-gas sampling and analysis were not conducted in this area.

Soil

Field inspection of this site found no visual evidence of soil contamination. Because no information exists that waste was ever handled in this area, soil sampling and analysis were not conducted. No radiation above normal background levels was detected in a field radiation survey conducted during February 1988 (Nemeth 1989).

\section{Surface Water}

As noted in Section 2.3.1.2, the USGS and the EPA ERT sampled surface water and sediment offshore from the RPTS.

\section{Groundwater}

Groundwater samples from monitoring well TH11 (Figure 2.15) were analyzed for extractable organic compounds. Results indicated very low levels of triethylchlorobenzene and TCLEE. As part of the 1986 RFA, the well was resampled for VOCs, BNAs, pesticides, and PCBs. No contaminants were detected.

An additional monitoring well (JF1) was installed near the tower by the USGS as part of their hydrological assessment (Sonntag 1991; Hughes 1993). The well is screened in the Potomac Group (Figure 2.13). Groundwater samples were analyzed for metals, water quality parameters, VOCs, and semivolatile organic compounds. Data for well JF1 showed low levels of VOC contamination (2.25 $\mu \mathrm{g} / \mathrm{L}$ 111TCE at a depth of 185-190 ft). However, this finding must be taken as provisional, because one of the two quality control water blanks also showed contamination with TCLEA, TCLEE, and TRCLE (USGS 1992). For the sake of comparison, an upgradient well (JF2) of similar depth, located at the J-Field gate entrance also had detectable concentrations of TRCLE during the same sampling episode. Acetone and 1,1-dichloroethane were detected at concentration of 4 and $1 \mu \mathrm{g} / \mathrm{L}$, respectively in a 1992 sampling event (USGS 1992).

\subsubsection{Potential Pathways of Contaminant Migration}

No information is available to verify that solid or hazardous waste was generated or handled at this site. A test burn of radioactive contaminated wood may have occurred at the 
site; however, the limited sampling conducted to date indicates that this area is not a source of contamination. Thus, there are no potential pathways for contaminant migration.

\subsubsection{Robins Point Demolition Ground}

\subsubsection{Types of Waste Present}

The inactive portion of the RPDG was used primarily for demolition of explosive materials. Small amounts of sensitive and unstable chemicals were occasionally destroyed at the area. A portion of the RPDG is still used for emergency disposal operations.

\subsubsection{Types of Contaminants Present}

\section{Soil Gas}

Soil-gas sampling and analysis were not conducted in this area.

\section{Soil}

Surface soil collected during the 1986 RFA was analyzed for metals, explosivesrelated compounds, and organic compounds. The analyses did not detect any contamination in the RPDG (Nemeth 1989).

Soil samples were collected by the USGS at 36 sites at J-Field, including the RPDG (locations 37 through 41 in Figure 2.11). The samples, collected at 1-ft depths, were analyzed for indicator parameters, metals, VOCs, semivolatile organic compounds, and explosives (Hughes 1992). The results indicated the presence of metals in low concentrations, including lead, up to $20.3 \mathrm{mg} / \mathrm{kg}$ at location 38 ; chromium, up to $16.3 \mathrm{mg} / \mathrm{kg}$ at location 37 ; copper, up to $75.5 \mathrm{mg} / \mathrm{kg}$ at location 37 ; and zinc, up to $22.8 \mathrm{mg} / \mathrm{kg}$ at location 39 . Limited analyses for organic compounds were also conducted; no significant contamination was found.

\section{Surface Water}

Laboratory analyses of standing water conducted during the 1986 RFA did not detect any contamination by metals, explosives, or organic compounds (Nemeth 1989).

\section{Groundwater}

Two monitoring wells were installed in the active portion of the RPDG in 1992 and will be sampled as a part of the RI. However, groundwater contamination is not expected 
given the short period of time the site was used, the nature of the operations, and the absence of soil and surface water contamination.

\subsubsection{Potential Pathways of Contaminant Migration}

Given the nature of the operations at the site and the absence of soil and surface water contamination, it is doubtful that any contamination still exists at this site. However, surface water that ponds west of a berm separating the active from the inactive portion of the RPDG seeps through the berm and discharges into the inactive portion of the site. As a result, surface water may play some role in contaminant migration in that surface runoff may carry dissolved and suspended contaminants from the active portion of the site into the inactive portion. 


\section{CONTAMINANTS OF CONCERN, EXPOSURE PATHWAYS, AND PRINCIPAL RECEPTORS}

\subsection{CONTAMINANTS OF CONCERN}

Chemicals of potential concern at J-Field are listed in Table 3.1, and the status of many of these contaminants, by AOC and media, is listed in Table 3.2. These materials, which are present in soil, sediment, surface water, and/or groundwater, could affect both terrestrial and aquatic biota. However, surveys of the biota within J-Field have not been conducted, and no information is available to indicate whether adverse ecological impacts have occurred at J-Field or to determine which organisms are at risk from potential contamination.

A final list of contaminants of ecological concern will be developed for each AOC by comparing media concentrations with a number of chemical-specific factors, such as regulatory standards, local background concentrations, benchmark toxicity values, and capacity to biomagnify. Media concentrations will be determined during the RI characterization activities. Figure 3.1 depicts the general decision path to be used for screening AOC contaminants for inclusion as final contaminants of ecological concern. However, regulatory, background, or benchmark values are not available for many of the contaminants identified in Table 3.1; these contaminants will be evaluated in the ERA.

\subsection{EXPOSURE PATHWAYS}

A conceptual site model for $J$-Field, which links sources and release mechanisms to receptors through various pathways and exposure routes, is presented in Figure 3.2. The model has been prepared on the basis of the current understanding of the contamination scenario (Section 2) at J-Field. It is expected that the site conceptual model will be modified as additional information is gathered.

In the conceptual site model, the primary sources of contamination are considered to be the eight AOCs. The primary release mechanisms associated with these AOCs are considered to be related to the primary waste-handling activities conducted at J-Field (i.e., OB/OD).

Several abiotic mechanisms may affect the secondary release of contaminants at the AOCs. These mechanisms may include surface runoff, wind dispersal, and groundwater recharge to surface waters. Abiotic factors that will also influence the fate and transport of contaminants following release include atmospheric conditions, groundwater flow (direction and rate), soil characteristics, surface drainage patterns, and local geochemistry and geohydrology. 
TABLE 3.1 Summary of Chemicals of Potential Concern for J-Field ${ }^{a}$

Organic Chemicals
Acetone (ACET)
Benzene (CH6)
Carbon tetrachloride (CCL4)
Chlorobenzene (CLC6H5)
Chloroform (CHCL3)
1,1-Dichloroethylene (11DCE)
1,2-Dichloroethylene (12DCE)
2,4-Dimethylphenol (24DMPN)
Ethyl benzene (ETC6H5)
Nitrobenzene (NB)
p-Chlorophenylmethyl sulfone (CPMSO2)
Phenol (PHENOL)
1,1,2,2-Tetrachloroethane (TCLEA)
Tetrachloroethylene (TCLEE)
Toluene (MEC6H5)
1,1,1-Trichloroethane (111TCE)
1,1,2-Trichloroethane (112TCE)
Trichloroethylene (TRCLE)
Vinyl chloride (C2H3CL)
PCBs (Aroclor 1248)
Assorted Fuels
Types of fuel used are unknown

\section{Metals and Anions}

Arsenic (AS)

Copper (CU)

Chromium (CR)

Cyanide (CYN)

Fluoride (F)

Lead (PB)

Mercury (HG)

Nickel (NI)

Nitrite/Nitrate (NIT)

Phosphorus (P)

Selenium (SE)

Sulfate (SO4)

Zinc (ZN)

Radioactive Materials

Strontium-90/Yttrium-90

Radium

Cesium-137

\author{
Lethal Chemical Agents \\ Tabun (GA) \\ Methylphosphonothioic acid (VX) \\ Mustard (H) \\ Sarin (GB)
}

\section{Incapacitating Agents/Liquid Smoke \\ Adamsite (DM) \\ Chloroacetophenone (CN) \\ o-Chlorobenzylidene malononitrile (CS) \\ Titanium tetrachloride (FS) \\ Sulfur trioxide/chlorosulfonic acid (FM) \\ Incendiary Materials \\ White phosphorus (WP) \\ Munitions Compounds \\ 2,4,6-Trinitrotoluene (TNT) \\ Cyclotetramethylene tetranitrate (HIMX) \\ Hexahydro-1,3,5-trinitro-1,3,5-triazine (RDX) \\ 2,4,6-Trinitrophenyl methylnitramine \\ Nitrobenzene \\ 1,3-Dinitrobenzene \\ Pentaerythritol tetranitrate (PETN)}

Chemical Warfare Agent Degradation Products ${ }^{b}$

Product
Hydrogen cyanide
Isopropyl methyl phosphonic acid
Methyl phosphonic acid
Ethyl methyl phosphonic acid
Thiodiglycol
1,4,-Dithiane
1,4-Oxathiane

Agent
GA
GB
GB, VX
VX
Mustard
Mustard
Mustard

Miscellaneous Compounds

Heptachlor epoxide

Chlordane

DDD, DDE, DDT

Pictric acid

PCBs (Aroclor 1248)

Hydrazine sulfate

a The Installation Restoration Data Management System (IRDMS) abbreviations for the chemicals are given in parentheses after each name, if appropriate.

b Via hydrolysis and other processes.

Sources: Adapted from ICF-Kaiser Engineers (1993a) and Benioff et al. (1995a,b). 
TABLE 3.2 Status of Contaminants of Potential Concern by Area of Concern and Medium

\begin{tabular}{|c|c|c|c|c|c|c|c|c|}
\hline \multirow[b]{2}{*}{ Contaminant $^{\mathrm{a}}$} & \multicolumn{8}{|c|}{ Area of Concern ${ }^{b, c}$} \\
\hline & TBP & WPP & RCP & $\mathrm{RPDG}^{\mathrm{d}}$ & RPTS $^{d}$ & SBDG $^{\mathrm{e}}$ & SBT & $\mathrm{PB}$ \\
\hline Arsenic & $\mathbf{s}$ & $\mathbf{s}$ & - & - & - & - & - & - \\
\hline Barium & - & $\mathbf{s}$ & - & - & - & - & - & - \\
\hline Cadmium & sg & sgw & $\mathbf{s}$ & - & - & - & - & $\mathbf{s}$ \\
\hline Chlordane & - & - & - & - & - & - & - & - \\
\hline Chromium & $\mathbf{s}$ & $\mathbf{s}$ & $\mathbf{s}$ & $\mathbf{s}$ & - & - & $\mathbf{s}$ & $s$ \\
\hline Copper & sg & $\mathbf{s}$ & $\mathbf{s}$ & $\mathbf{s}$ & - & - & $\mathbf{s}$ & - \\
\hline CS (tear gas agent) & - & - & - & - & - & - & - & - \\
\hline Cyanide $\mathrm{f}^{\mathrm{p}}$ & gw & sgw & - & - & - & - & - & - \\
\hline Dimethyl disulfide & - & - & - & - & - & - & - & $\mathbf{g}$ \\
\hline Dimethylnaphthalene & - & - & - & - & - & - & - & - \\
\hline Heptachlor epoxide & - & - & - & - & - & - & - & $\mathbf{s}$ \\
\hline Lead & swg & sgw & $\mathbf{s}$ & $\mathbf{s}$ & - & - & s & $\mathbf{s}$ \\
\hline Mercury & swg & - & - & - & - & - & - & - \\
\hline Naphthalene compounds & - & - & - & - & - & - & $\mathbf{s}$ & - \\
\hline Nickel & - & $\mathbf{s}$ & $\mathbf{s}$ & - & - & - & - & - \\
\hline $\mathrm{PAH}^{\mathrm{g}}$ & $\mathbf{s}$ & - & - & - & - & - & - & - \\
\hline $\mathrm{PCB}^{\mathrm{g}}$ & $\mathbf{s}$ & $\mathbf{s}$ & - & - & - & - & - & - \\
\hline Phosphorus & $\mathbf{s}$ & - & - & - & - & - & - & - \\
\hline Selenium & - & g & - & - & - & - & - & - \\
\hline Silver & $\mathbf{s}$ & - & $\mathbf{s}$ & - & - & - & - & - \\
\hline Sulfate & $\mathbf{s}$ & - & - & - & - & - & - & - \\
\hline Trichloroethylene & sgw & g & - & - & .. & - & - & - \\
\hline VOCg & sg & $\mathbf{s}$ & $\mathbf{s}$ & - & - & - & - & - \\
\hline Zinc & $\mathbf{s}$ & $\mathbf{s}$ & $\mathbf{s}$ & $\mathbf{s}$ & - & - & - & $\mathbf{s}$ \\
\hline 1,1,1-Trichloroethane & - & - & - & - & - & - & - & g \\
\hline 1,3-Dithiane & g & - & - & - & - & - & - & - \\
\hline $4,4^{\prime}-\mathrm{DDD}$ & - & - & - & - & - & - & - & $\mathbf{s}$ \\
\hline $4,4^{\prime}-\mathrm{DDE}$ & - & - & $\mathbf{s}$ & - & - & - & - & $\mathbf{s}$ \\
\hline $4,4^{\prime}-\mathrm{DDT}$ & - & - & $\mathbf{s}$ & - & - & - & - & s \\
\hline
\end{tabular}

a This list of contaminants is not inclusive.

b TBP = Toxic Burning Pits, WPP = White Phosphorus Burning Pits (includes ditch to the north), RCP = Riot Control Burning Pit, RPDG = Robins Point Demolition Ground, RPTS = Robins Point Tower Site, SBDG = South Beach Demolition Ground, SBT = South Beach Trench, and PB = Prototype Building.

c Status codes: $s=$ contaminant of potential concern in the soil, $g=$ contaminant of potential concern in the groundwater, and $w=$ contaminant of potential concern in the surface water or sediment. A hyphen indicates that the contaminant is currently not of potential concern in any medium at this AOC. Results of ongoing characterization activities may result in the inclusion of contaminants not previously identified for some AOCs.

d No contaminants of concern have been specifically identified.

e No contaminants of concern have been specifically identified; due to shoreline erosion, this site is currently inundated by Chesapeake Bay. Surface water and sediment from a nearby detonation crater will be sampled.

f Cyanide may be present at other J-Field sites.

g $\mathrm{PAH}=$ polyaromatic hydrocarbon; $\mathrm{PCB}=$ polychlorinated biphenyl; $\mathrm{VOC}=$ volatile organic compound, including chlorobenzene, 112TCE, TCLEA, vinyl chloride, trans-12DCE, TRCLE, TCLEE.

Source: From data presented in Section 2. 


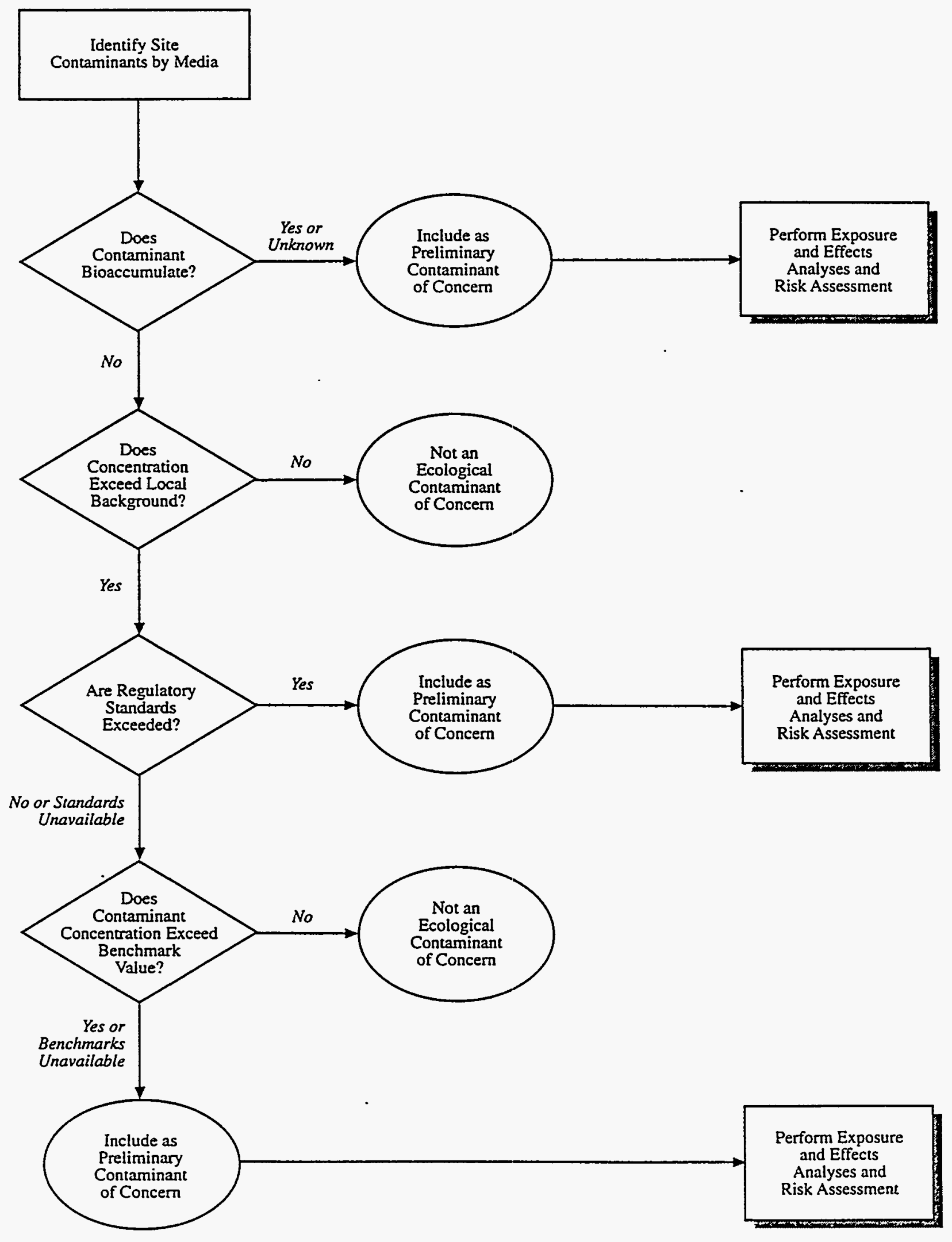

FIGURE 3.1 Decision Path for Selection of Preliminary Ecological Contaminants of Concern for J-Field 


\begin{tabular}{|c|c|c|c|c|c|c|c|}
\hline $\begin{array}{l}\text { Primary } \\
\text { Sources }\end{array}$ & $\begin{array}{c}\text { Primary } \\
\text { Release } \\
\text { Mechanism }\end{array}$ & $\begin{array}{c}\text { Secondary } \\
\text { Sources }\end{array}$ & $\begin{array}{c}\text { Secondary } \\
\text { Release } \\
\text { Mechanism }\end{array}$ & Pathway & \multirow{2}{*}{$\begin{array}{c}\text { Exposure } \\
\text { Route }\end{array}$} & \multicolumn{2}{|c|}{$\begin{array}{l}\text { Ecological } \\
\text { Receptors }\end{array}$} \\
\hline \multirow{15}{*}{$\begin{array}{l}8 \text { Areas } \\
\text { of Concern }\end{array}$} & \multirow{15}{*}{$\begin{array}{l}\rightarrow \begin{array}{c}\text { Burning, } \\
\text { Detonation }\end{array} \\
\rightarrow \begin{array}{l}\text { Infiltration/ } \\
\text { Percolation }\end{array}\end{array}$} & \multirow{4}{*}{$\begin{array}{c}\text { Debris } \\
\text { Soil }\end{array}$} & \multirow{4}{*}{$\begin{array}{c}\text { Volatilization } \\
\text { from Water, } \\
\text { Wind, } \\
\text { Suspension } \\
\text { of Dust }\end{array}$} & \multirow[b]{3}{*}{$\rightarrow \quad$ Air } & & Terrestrial & Aquatic \\
\hline & & & & & Ingestion & & \\
\hline & & & & & Inhalation & - & \\
\hline & & & & & Dermal & & \\
\hline & & & Secondary & & Inoestion & 9 & \\
\hline & & & or Release & Soil & Inhalation & & \\
\hline & & water & & & Dermal & 0 & \\
\hline & & & $\begin{array}{c}\text { Surface } \\
\text { Water Runoff }\end{array}$ & & In & & \\
\hline & & & & Surface & Inhalation & & \\
\hline & & & Infiltration/ & Sediments & Dermal & - & - \\
\hline & & & & $\uparrow$ & Rool Uptake & - & 0 \\
\hline & & & & & Ingestion & & \\
\hline & & & & Ground- & Inhalation & & \\
\hline & & & & & Dermal & & \\
\hline & & & & & Root Uplake & - & \\
\hline
\end{tabular}

FIGURE 3.2 Ecological Conceptual Site Model for J-Field 
In addition to these abiotic factors, several biotic mechanisms play important roles in the release, fate, and transport of contaminants. These biotic mechanisms may include the direct uptake of contaminated media by vegetation or wildlife, the transfer of contaminants through food chains by on- and off-site biota and, to a lesser degree, the tracking by biota of contaminants from source areas to either on- or off-site locations. Biota at the site may uptake contaminants directly via (1) ingestion of contaminated media, (2) inhalation of contaminated media, or (3) absorption of contaminants across body surfaces during contact with contaminated media.

The ultimate ecological fate and effects of the contaminants will depend on the type (terrestrial or aquatic) and form (grassland, forest, stream, or lake) of the ecosystem in which the contaminant occurs, the nature and concentration of the contaminant in the media, the length of exposure of the biota to the contaminant, and the nature of the food chain that the contaminant enters.

\subsection{PRINCIPAL RECEPTORS}

Ecological receptors are biotic species selected as "indicators" to determine whether contaminants are having a demonstrable effect on biotic communities. Species are selected as ecological receptors on the basis of their trophic level, habits, sensitivity, or commercial and recreational importance. The selection of species as trophic level indicators would depend on the contaminant of concern. For contaminants known to biomagnify (e.g., mercury), species at the top of the food chain (e.g., predators) would be likely candidates. However, for most metals and other contaminants that do not demonstrate biomagnification, plant species, herbivores, or detrivores would be selected as receptor species. Ecological receptors chosen for their habitats would be species whose life history places them in direct contact with contaminants. Such species include those inhabiting or feeding within or upon sediments or soils (e.g., earthworms, amphipods, benthic insect larvae, tadpoles, bottom-feeding fish).

Species selected as generally appropriate receptors for APG are identified in ICF-Kaiser Engineers (1993a). A preliminary list of receptor species for the J-Field site is provided in Table 3.3. These species were identified from the preliminary list of receptor species given in ICF-Kaiser Engineers (1993a) and from field observations by ANL biologists

at J-Field. A final list of receptor species will be developed from the results of the biotic surveys that will be conducted at J-Field. 
TABLE 3.3 Preliminary List of Ecological Receptors for J-Field

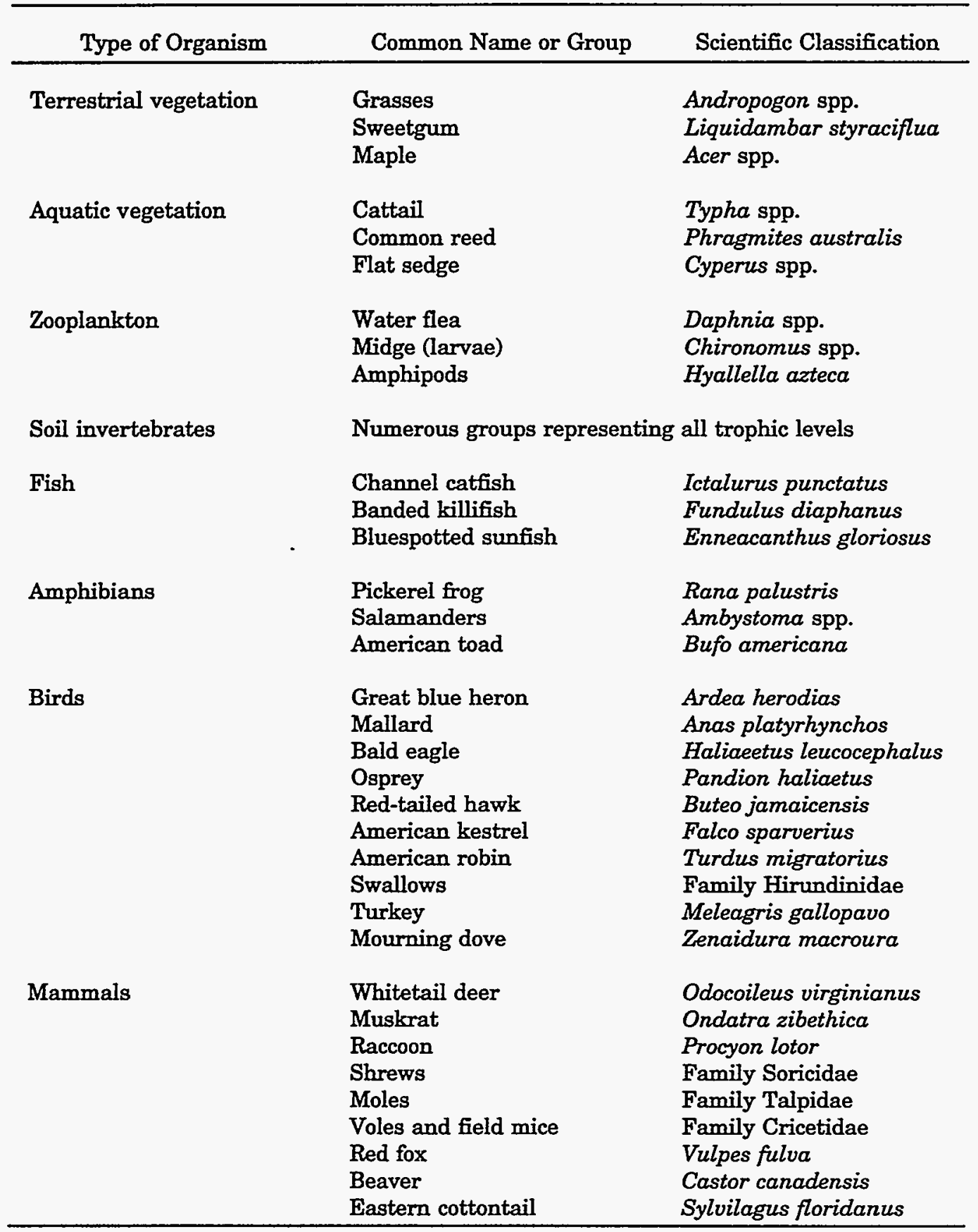

Source: ICF-Kaiser Engineers (1993a) and field observations. 
3-8 


\section{OBJECTIVES AND SCOPE OF THE RISK ASSESSMENT}

The tasks described in this section include field assessments, toxicity assessments, and ecosystem modeling to evaluate existing and potential ecological risks at J-Field. In the J-Field ERA design, these approaches are considered to be complementary, rather than separate, assessment methodologies. This three-way approach mirrors that proposed for the overall APG ecological risk characterization (ICF-Kaiser Engineers 1993a).

A generic approach has been developed for conducting ERAs at APG (ICF-Kaiser Engineers 1993a). The approach proposed by ANL for the J-Field ERA follows that proposed for all of APG, with a few exceptions. A preliminary ERA (USATHAMA 1991) provided initial scoping of potential contamination and ecological effects at J-Field. The conclusions from that preliminary assessment identified the need for an ERA at selected areas of J-Field.

The J-Field ERA has been designed to address the following specific questions about the ecological effects of contamination at J-Field:

1. Are contaminants in J-Field environmental media producing demonstrable ecological effects at the population, community, or ecosystem levels? If so, what are the extent and magnitude of the effects?

2. Are contaminated environmental media at J-Field directly toxic to biota? If so, what types of organisms are affected and where are they located?

3. Are contaminants in environmental media at J-Field capable of producing effects on biota through bioaccumulation, food chain, or other secondary mechanisms? If so, what are the exposure pathways and the extent and magnitude of risk?

By answering these questions, the studies conducted for the ERA will provide the risk manager with information to (1) evaluate, from an ecological perspective, whether remedial action is necessary at any of the J-Field sites; and (2) determine whether the site hosts valuable biological communities that could be adversely affected if remediation is warranted and remedial activities are implemented. In addition, the ERA will also identify the relative contribution, by media, of each AOC to the overall ecological risk posed by site contamination. This information will thus aid the project manager in targeting remedial activities and costs on those AOCs and media that contribute most to the risks to ecological resources at J-Field.

\subsection{GENERAL APPROACH}

Because of the uncertainties about the extent and ecological impacts of the J-Field contamination, a phased approach has been adopted for this ERA (Figure 4.1). This approach 


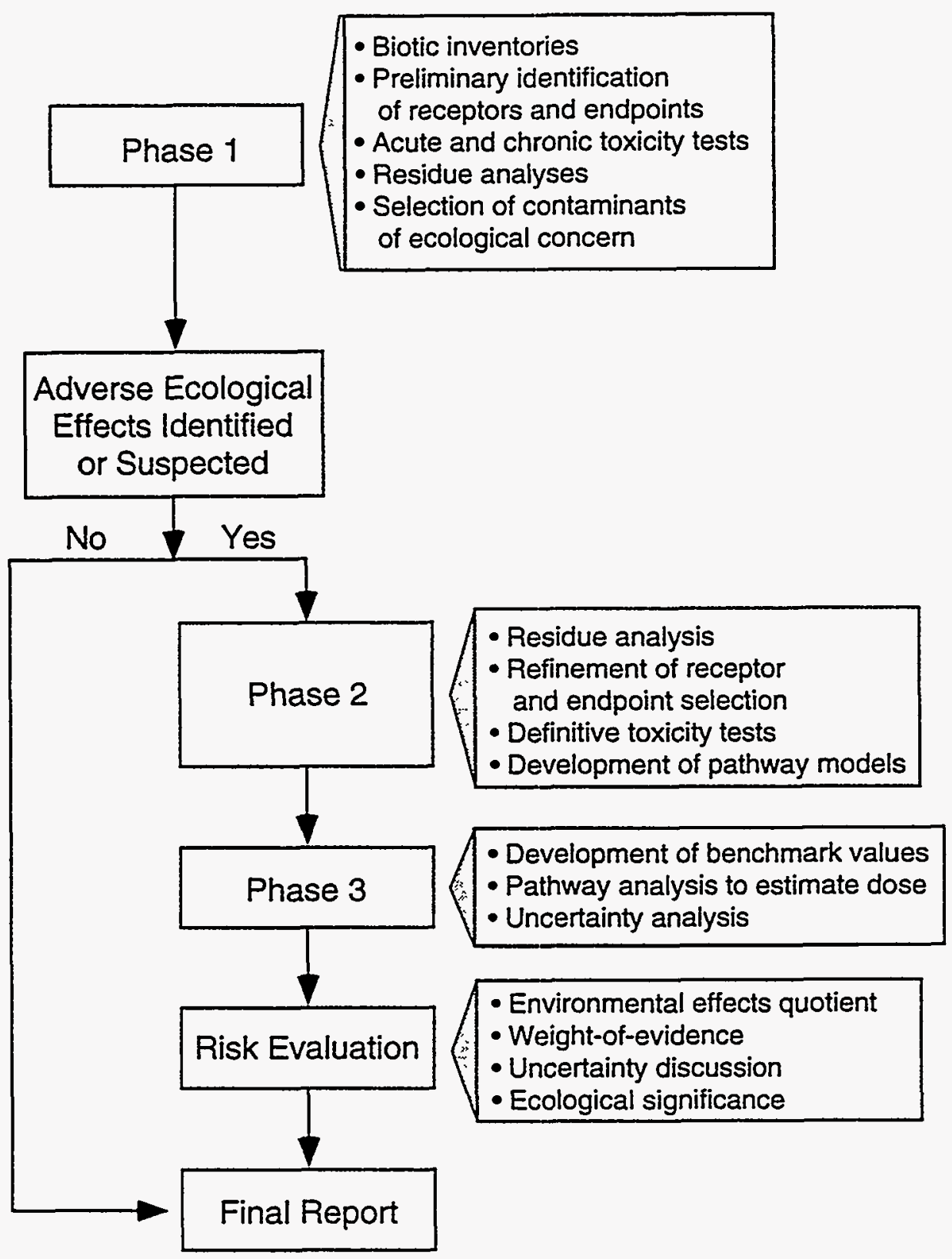

FIGURE 4.1 Phased Approach Proposed for J-Field Ecological Risk Assessment 
is based on the need to establish an environmental baseline for the assessment of ecological risks and on the fact that little is known about the impacts to ecological systems from some types of contaminants at APG. A phased approach is a common methodology for all ERAs at APG (ICF-Kaiser Engineers 1993a). Modifications to the types of work conducted under each phase may be necessary, depending on the results of studies conducted in the previous phase.

Phase 1 of the ERA will determine (1) whether ecological effects from contamination are evident, on the basis of the distribution and abundance of biota relative to the extent and magnitude of the contamination; and (2) whether the media from the primary area(s) of contamination at J-Field are toxic to biota. Phase 1 will also identify the ecological receptors, assessment endpoints, and methods for Phase 2. Population estimates for biota and residual analysis of organisms collected during the biotic surveys will also provide necessary data for the pathway analyses to take place during Phase 3. Biological surveys, which are described in Section 5 of this ERA work plan, will be conducted at contaminated areas of J-Field, as well as one or more reference sites with ecological characteristics comparable to contaminated habitats at J-Field. Reference sites will be selected from those identified in ICF-Kaiser Engineers (1993a). Areas of contamination will be identified through physical media analyses (as part of the RI site characterization activities), and toxicity testing will be performed to determine whether contaminated media are toxic to biota.

Phase 2 will include (1) definitive toxicity testing to determine how organisms are affected by contaminated environmental media (e.g., development of dose response relationships); (2) additional residue analyses (to develop exposure profiles); and (3) the preliminary development of pathway models for estimating dose to higher trophic level receptors. Final selection of appropriate receptors for the Phase 3 pathway analysis will be made at the conclusion of Phase 2 activities, and pathway models will be developed for these receptors.

Phase 3 will include (1) pathway analyses to estimate contaminant dose to receptors and (2) development of site-specific benchmark values for use in estimating risk. Probabilistic modeling and sensitivity analyses will be employed to evaluate uncertainty in the pathway models.

\subsection{PHASE 1 APPROACH}

Three general types of information are needed to establish a relationship between the occurrence of chemical contamination at J-Field and any ecological effects (EPA 1989a):

1. Chemical analyses of the appropriate media are needed to establish the presence, areal and vertical distributions, and concentrations of contaminants.

2. Ecological surveys are needed to determine if adverse ecological effects have occurred. 
3. Toxicity tests are needed to identify potential ecological impacts and to establish a link between any realized adverse ecological effects and the toxicity of chemical contaminants.

The null hypothesis for this phase of the study is that areas of chemical contamination do not affect the ecological properties of J-Field. The appropriate first component of this phase of the assessment is a determination of whether there is any evidence of ecological effects present in areas of known or suspected contamination. Phase 1 will involve biotic surveys to determine the current condition of a selected number of ecological parameters related to the distribution and abundance of biota at potentially contaminated areas and at uncontaminated reference sites. The reference sites, which will be selected from those identified by ICF-Kaiser Engineers (1993a), will be based on similarity of habitat with J-Field survey locations.

The second component of this phase is acute and chronic toxicological testing using $\mathrm{J}$-Field media. The purpose of these tests is to determine whether any of the media known or suspected to be contaminated are toxic to biota and thus pose a potential adverse risk to biota at the site. The results of these tests will be used to identify areas of the site in need of further ecological investigation and to identify areas of the site that do not pose a risk and can be removed from further consideration in the ERA.

The third component of this phase is the analysis of chemical residuals in biota in order to document exposure to and uptake of site contaminants by indigenous biota. This information will assist in the development of exposure profiles for selected ecological receptors and will also provide needed data for performing the pathway analyses of Phase 3.

Further studies will not be required for any AOC if none of the three components of Phase 1 shows positive results. If positive results (e.g., affected distribution or abundance, media toxicity, or contaminants in tissues) are obtained for one or more of the three components, the ERA will proceed into Phases 2 and 3.

\subsection{PHASE 2 APPROACH}

Phase 2 of the ERA will be implemented at any AOC for which the results of Phase 1 show (1) differences in the distribution and abundance of biota between contaminated and uncontaminated areas, (2) toxicity of site media to biota, or (3) bioaccumulation of contaminants in tissues or organs of site biota. Phase 2 will include definitive toxicity testing to develop media-based dose response relationships and to indicate the dilutions of media that are necessary to remove toxic effects.

Additional tissue residue analyses will be conducted for selected biota from areas of J-Field where the Phase 1 studies indicate media toxicity or where the RI characterization activities detect contaminants known to bioaccumulate. Final selection of receptors for Phase 3 of the ERA will be based on the results of the Phase 1 and Phase 2 investigations. 
Data from Phases 1 and 2 will also be used to develop exposure pathways and food chain relationships for the pathway analysis models that will be used in Phase 3.

\subsection{PHASE 3 APPROACH}

In Phase 3, results from the RI characterization activities, biotic surveys, residual analyses, and toxicological studies conducted during Phases 1 and 2 will be used to document exposure and potential or actual adverse effects to ecological receptors at J-Field. Phase 3 studies will include a refinement of the exposure pathways developed as part of Phase 2 . The exposure pathways will then be imported into STELLA ${ }^{\text {TM }}$ (Costanza 1987; Shatkin and Brown 1991), a systems dynamics software package, to evaluate contaminant doses to higher trophic level receptors. Specifically, STELLA ${ }^{\mathrm{TM}}$ will be used to model contaminant movement through food chains at J-Field and to estimate an applied daily dose to receptors. The models will use the general dose-estimation approaches discussed in the EPA Wildlife Exposure Factors Handbook (EPA 1993). However, the pathway models will be developed to incorporate, to the fullest extent possible, site-specific food chains, exposure routes, and wildlife exposure factors. If site-specific exposure factors are unavailable, the most appropriate exposure factors found in the EPA handbook (EPA 1993) will be used for dose estimation. Uncertainty associated with the pathway analysis will be evaluated using Crystal Ball ${ }^{\mathrm{TM}}$, a Monte Carlo simulation uncertainty evaluation software package (Decisioneering, Inc. 1993).

\subsection{RISK EVALUATION}

In contrast to risk assessments for human health, there is no standard approach for estimating risk to ecological resources (EPA 1992b). The EPA framework for ecological risk assessments discusses the use of both qualitative and quantitative approaches for evaluating risk. For the J-Field ERA, risk evaluation will be both qualitative and quantitative and will generally follow the draft interim guidelines developed at EPA Region III (Davis 1994). Environmental effect quotients (EEQs) will be estimated for each contaminant of concern and each environmental medium of concern. The EEQ approach is analogous to the hazard quotient approach used in quantifying risks of noncarcinogens to humans. The data generated by Phases 1 and 2, as well as the dose and uncertainty analyses conducted during Phase 3, will also be employed in a weight-of-evidence risk evaluation approach (EPA 1992b) to provide a more robust quantitative estimation of risk.

Qualitative and quantitative discussions of uncertainty associated with all phases of the ERA will be provided. The risk evaluation will specifically address uncertainty associated with the conceptual site model, natural ecological variability, assumptions used in the pathway models, and extrapolations of data across taxa, as well as the implications of uncertainty to the overall ERA.

The risk evaluation will also discuss the ecological significance of the predicted risks and will address (1) which receptors are most at risk; (2) where the greatest impact is likely 
to occur; (3) what the expected magnitude of the impact is; (4) how the likelihood and magnitude of impacts are related; and most importantly, (5) what the impact means to the ecology of J-Field and to the Chesapeake Bay ecosystem as a whole.

\subsection{CONSULTATIONS}

To assist in formulating and refining the objectives of this ERA, appropriate federal and state agencies will be consulted. These consultations will include the regional Biological Technical Assistance Group (BTAG), which consists of officials from EPA and other agencies that are natural resource trustees under Superfund (e.g., U.S. Department of the Interior and National Oceanic and Atmospheric Administration). The main functions of BTAG are to (1) provide a forum for communication among agencies; (2) identify ecological concerns and valued ecological resources; (3) determine data needs; and (4) make recommendations, including suggested monitoring and assessment activities, sampling plans, analytical techniques, ecological endpoints, ecologically based ARARs, and beneficial and detrimental aspects of possible remedial actions (EPA 1989c).

In addition, risk assessment activities conducted at J-Field will be coordinated with other CERCLA ecological assessment activities at APG. The primary interaction will be with ICF-Kaiser Engineers, which is responsible for ensuring a coordinated approach for risk assessment at APG (ICF-Kaiser Engineers 1993a). ANL staff will communicate regularly with ICF-Kaiser Engineers staff to exchange results, ideas, methods, and conclusions.

\subsection{REPORT PREPARATION}

At the conclusion of Phase 3, ANL will prepare a final report that presents the results of the Phase 1 and Phase 2 field and laboratory investigations and of Phase 3 modeling. The report will describe the areas sampled (terrestrial, wetland, estuarine); summarize the results of the surveys, toxicity tests, and chemical analyses; present the model assumptions and parameters; and present other necessary and relevant data that contribute to the final ERA for J-Field. The final report format will follow that proposed by EPA (1992b).

A number of interim reports will be prepared during the ERA. The first report will present the methods, results, and analysis of data from Phase 1 studies conducted during calendar years 1993 and 1994. That report will also identify work to be completed in 1995 . A second report will present the methods, results, and analysis of data from any remaining Phase 1 studies and from Phase 2 studies conducted during calendar year 1994 and 1995. A third report will be prepared to document the approach, methodology, and results of Phase 3.

In addition to these three interim reports, a number of technical update reports will be prepared. These update reports will present the data generated by ANL and its subcontractors during the field and laboratory investigations. The update reports will present only data, with little or no analysis. 


\section{SAMPLING AND ANALYSIS}

This section describes the field and laboratory work to be conducted as part of the ERA at J-Field. This description is limited to ecological studies, including biotic surveys, residual analysis, and toxicity assessment. Studies of media contamination and pathway identification are described in the FSP for J-Field. The sampling, data collection methods, and analysis described in this ERA work plan also generally follow those outlined for the overall APG risk assessment (ICF-Kaiser Engineers 1993a) and the O-Field risk assessment (ICF-Kaiser Engineers 1992).

\subsection{PHYSICAL MEDIA}

Sampling and analysis to determine contaminant levels in physical media (air, soil, sediment, and water) at J-Field are described in the FSP. The purpose of the FSP studies is to (1) determine the nature and extent of contamination at each of the eight AOCs, (2) identify pathways of contaminant migration, and (3) provide data needed to conduct human and ecological risk assessments at the site.

The ecological assessment work described in this ERA work plan will use the QA/QC procedures and chain-of-custody procedures described in the J-Field Quality Assurance Project Plan (QAPJP). Detailed QA/QC procedures will also be provided in subcontractors' sampling and analysis plans.

Selection of transects or grids for biotic surveys will be coordinated with the physical media sampling locations identified in the FSP. This process will allow inferences to be made about the relationship between chemical contamination and observed ecological effects. Past media sampling of groundwater, surface water, and soil (Section 2) provides a preliminary assessment of the spatial extent of contamination.

As noted in the FSP, an important constraint on analysis of physical media from $\mathrm{J}$-Field is that samples suspected of CWA contamination cannot be sent off-site until the samples have been screened for CWAs by APG. For those media that can be sent off-site (e.g., water and biological materials and CWA-screened soils and sediments), chemical analysis will include compounds on the TCL and TAL, CWA degradation products, and explosives and explosives-related compounds (Table 5.1).

The locations identified in the FSP for sampling of physical media include the primary site of contamination, as well as downgradient locations. However, the transport and fate of the contaminants at each of the potentially contaminated areas have not been documented. Available data suggest that until the results of planned physical media characterization are known, ecological sampling associated with contaminated areas should focus on areas in and around identifiable potential point sources (such as pits and trenches) and on areas in adjacent, downgradient terrestrial, wetland, and open water habitats. 
The location of biotic surveys will be closely coordinated with the sampling locations identified in Section 4 of the FSP for the RI site characterization activities. This strategy will serve to link the biological data with the physical and chemical data and provide a basis for ecological interpretation of the physical and chemical data. Parameters to be measured as part of the ERA include temperature (water), $\mathrm{pH}$ (water, soil, and sediment), dissolved oxygen content (water), turbidity (water), and grain size (soil and sediments).

\subsection{BIOTIC SURVEYS}

The purpose of conducting biotic surveys is to determine (1) whether observable ecological differences exist between contaminated (J-Field) and uncontaminated (reference) sites and (2) the occurrence of ecological receptors that may be the target biota of Phase 2 and Phase 3 activities. Data to be obtained in the surveys will be of species/taxon composition and abundance. Interpretation of these data will consider species diversity, taxon dominance, and percent of species that are tolerant or intolerant of anthropogenic stressors. Samples of selected species in each community may be collected for residual analysis.

\subsubsection{Terrestrial Habitats}

Analyses of the terrestrial habitats within J-Field and at reference sites will include interpretation of aerial photography (particularly low-altitude photography), coupled with ground-truthing (selective on-site verification of image interpretation). These data can provide information on vegetation community homogeneity, edges and habitat patterns, and areal coverage of terrestrial vegetation types. All aerial photography will be placed in a digital database for evaluation with geographic information system (GIS) tools.

Quantitative sampling of terrestrial flora at on-site and reference locations will follow commonly accepted methods (e.g., Mueller-Dombois and Ellenberg 1974; Barbour et al. 1987). Species and diameter at breast height will be recorded for each woody specimen. In addition, total canopy cover (percentage) will be recorded. Species, percentage cover, and biomass will be recorded for herbaceous samples. These data will be used in estimating population and community parameters.

Soil and litter biota, including bacteria, fungi, and protozoa, will be sampled with established collection methods to allow quantitative comparisons among sites. Invertebrates will be sampled with soil cores and pitfall traps. Terrestrial habitats will also be evaluated 
for soil processes, such as litter decomposition, enzyme activities, and nutrient cycling with the methods described in Appendix A. Collections of invertebrates using standard sampling methods will also be made for analysis of chemical residuals.

Amphibian, reptile, and bird surveys will be limited primarily to observational surveys and identification of vocalizations. For birds, the surveys will be conducted during spring and autumn migrations, and the breeding season. Some resident birds may be collected and analyzed for chemical residuals. Amphibian surveys will be conducted primarily in spring and early summer and timed to coincide with the breeding periods for the local amphibian populations.

Mammals will be sampled by EPA Class 1 techniques (EPA 1989c), using live traps and snap traps. All animals collected will be identified, weighed, and sexed (if possible), and those collected using live traps will be marked and released. Tissues and organs from some specimens will be analyzed for chemical residuals.

\subsubsection{Open Water Habitats}

Analyses of the open water habitats within J-Field and at reference sites will include interpretation of aerial photography (particularly low-altitude photography), coupled with ground-truthing (selective on-site verification of image interpretation). These data can provide information on open-water patterns (e.g., seasonal and long-term), occurrence and areal coverage of macrophytes, occurrence and extent of sediment plumes, occurrence and intensity of algal blooms, and evidence of wildlife activity. All aerial photography will be placed in a digital database for evaluation with GIS tools.

Communities surveyed in open water habitats will include aquatic macrophytes, benthic macroinvertebrates, and fish. Benthic macroinvertebrate communities will be sampled twice per year - once in the late spring/early summer and once in the late fall. Methods used to inventory benthic macroinvertebrate communities may include nets, grab samples, and artificial substrates collected from quadrants or transects stratified according to major environmental gradients within the habitat. Methods of benthic collection will depend on sediment type and the amount of aquatic vegetation. Sampling of benthic macroinvertebrates may be limited in some areas due to CWA and UXO safety concerns. Representative collections will be preserved and placed in an APG site collection maintained at ANL.

Standard techniques for sampling fish will be used and will vary with habitat type and expected species. These methods include the use of electroshockers, hooks and lines, seines, or minnow traps. Fish sampling will be designed to provide estimates of species composition and diversity. 


\subsubsection{Wetland Habitats}

Analyses of the freshwater wetlands within J-Field and at reference sites will include interpretation of aerial photography (particularly low-altitude photography), coupled with ground-truthing (selective on-site verification of image interpretation). These data can provide information on wetland vegetation community homogeneity; wetland edge and open-water patterns (e.g., seasonal and long-term); occurrence and areal coverage of vegetation; and occurrence and number of muskrat dens, waterfowl nests, or other indicators of wildlife activity. All aerial photography will be entered into a digital GIS database, and maps showing the wetland areas will be developed for each AOC. The maps will be useful for interpretation of contaminant concentration contours, surface water and groundwater flow patterns, areas of physical disturbance, and other factors. The GIS data will provide an initial analysis of wetland areas of potential ecological concern relative to contaminant migration.

The purpose of field sampling within the wetlands will be to determine community composition and the distribution of receptor species for which risk will be assessed. Wetland surveys will be conducted seasonally. Data recorded will include species composition and density, as well as percent vegetative cover. Interpretation of these data will include species diversity and dominance and percent occurrence of exotic and native species. A jurisdictional wetland delineation (Environmental Laboratory 1987) and characterization (Cowardin et al. 1979) will be performed. These activities will be used to formulate sampling strategies and to interpret the extent of risk to species and habitats. Observational data on wetland conditions can provide potentially useful indications of ecosystem stress (Leibowitz and Squires 1991). Such observational field data would include notation of debris accumulations, plant dieback, and/or reduced pigmentation.

Surveys of macrophytes will coincide with the period of maximum macrophyte growth (e.g., middle to late summer). Methods used to inventory wetland vegetation will include point counts, quadrants, or other established plant sampling techniques (Bureau of Land Management 1986). Voucher specimens will be deposited in an APG site collection maintained at ANL.

Methods used to survey the composition of invertebrate communities will include visual surveys and sediment sampling and screening. However, safety concerns related to CWAs and UXO may preclude sediment sampling in some areas. Sampling of sediment-dwelling and surface-dwelling macroinvertebrates will include quadrants or transects chosen randomly within positions stratified by vegetation cover, elevation, and sediment type. A variety of methods (e.g., sediment corers, dredges or grab samplers, artificial substrates, sweep and dip nets, emergence traps) will be used to collect invertebrates. Methods used will depend on the habitat and habits (e.g., sediment, open water, epiphytic) of the invertebrates. Invertebrate surveys will be designed to provide estimates of species density, distribution, and diversity. Representative collections will be deposited in an APG site collection maintained at ANL. 
Surveys of terrestrial vertebrates will correspond to seasonal use patterns and will predominantly rely on visual surveys. Vertebrates inventoried within wetlands will include resident and migratory songbirds, shorebirds, water birds, raptors, amphibians, and reptiles. The purpose of wetland vertebrate surveys will be to provide estimates of species density, distribution, and diversity. Areas of importance to shorebird and amphibian/reptile life cycles (e.g., feeding and breeding concentration areas) will be identified, if present, and visual surveys will be conducted at least twice during periods of greatest potential activity. Drift fences with pitfall traps or funnel traps may be used to collect amphibians and reptiles that are not readily observable. As discussed for sediment sampling; safety concerns related to CWAs and UXO may preclude the use of pitfall traps.

\subsection{RESIDUAL ANALYSIS}

Tissue or whole-body analyses (plant or animal) can identify sublethal and chronic, low-level exposure to a source of pollution (EPA 1991), even if no effects are observed in biotic surveys or detected by toxicity tests. In addition, it will be necessary to determine contaminants in biota in order to conduct the pathway analyses in Phase 3 of the ERA. Samples of vegetation, terrestrial and aquatic invertebrates, amphibians, small mammals, and birds will be collected from a number of areas at J-Field. Samples from both J-Field and the reference sites will be analyzed for residuals after media analyses indicate which potential contaminants are of concern relative to biouptake and bioaccumulation. The samples may be analyzed for TCL compounds, TAL elements, or CWA degradation products. The final analyte list will vary among AOCs and will be a function of the nature of the contaminants present. Biotic contaminant analyses may involve organs or tissues in which contaminants of concern are known to accumulate (for sublethal or chronic assessments) and whole body concentrations (for trophic analysis assessments).

\subsection{TOXICITY TESTING}

Media toxicity at J-Field and the reference sites will be determined for terrestrial and aquatic organisms. At each AOC, the media to be tested will be collected from the same location (or as close as possible) where samples will be collected for chemical analysis. Test methods and species will generally follow those proposed by ICF-Kaiser Engineers (1993a, Section 4.5). Because this work plan addresses ecological risks specific to J-Field, some methods and choices of toxicity tests and target organisms may differ from or supplement those in the technical plan proposed for the entire APG area (ICF-Kaiser Engineers 1993a).

Toxicity tests will evaluate site media and will include screening tests and acute and chronic tests. These tests will serve to determine (1) spatial and temporal distribution in contamination and (2) the relationship between contaminant concentrations and any observed ecological differences between contaminated and uncontaminated areas. Furthermore, such tests will accompany chemical residue data to predict biouptake and food chain transfer through pathway analysis. Media-based toxicity tests, rather than tests of specific, individual chemicals, will be used because of the mixture of contaminants expected at J-Field. Media 
tests can indicate toxicity of mixtures of contaminants more readily than can single-chemical criteria (EPA 1989a). Because all species are not equally sensitive to contaminants, a variety of toxicity tests involving individual species from different trophic levels will be employed to fully assess soil, sediment, and water quality (Ingersoll 1991). Several sensitive, single-species tests are often adequate to identify sources and probable causes of toxicity at hazardous waste sites (Warren-Hicks et al. 1989).

\subsubsection{Acute and Chronic Toxicity Testing}

Acute or chronic toxicity tests will be performed on media for which the screening toxicity tests indicate toxicity or where the chemical characterization results indicate high and potentially adverse concentrations of contaminants. The acute and chronic tests identified in ICF-Kaiser Engineers (1993a) will be used, and all testing will follow the guidance and practices accepted by the American Society for Testing and Materials (ASTM) $(1980,1990 \mathrm{a}-\mathrm{d})$ as feasible. Acute and chronic bioassays proposed for testing the toxicity of $\mathrm{J}$-Field media are listed in Table 5.2.

Several tests have been chosen to supplement those used by ICF-Kaiser Engineers (1993a). Methods to assess the toxicity of freshwater sediments are discussed by Burton (1991). These documents include choices of biotic species for testing, as well as sample collection, handling, and testing procedures. Other supplemental tests and species appropriate to the physical, chemical, and biological conditions of the J-Field sites and that may be considered for evaluating media toxicity are discussed below.

In addition to tests with freshwater alga, Selenastrum capricornutum (ICF-Kaiser Engineers 1993a) survival and growth of Lemna sp. (duckweed) or other free-floating plant species will be used to monitor acute and chronic toxicity, respectively, of surface water. The use of only an algal species or a vascular plant species is not as sensitive for screening contaminants as is the use of both plant types (Fletcher 1990). Unlike rooted vascular plants, which have been shown to have unsatisfactory correlations for biomonitoring of sediment-bound metals (Outridge and Noller 1991), free-floating vascular plants have been shown to be reliable indicators of water pollution. Culture and experimental conditions will follow published methodologies (Wang 1986b; Fletcher 1990; Cowgill et al. 1991). Testing endpoints include changes in survival, the number or size of plants and fronds, or dry weight.

Several tests are available for evaluating soil toxicity, and the most widely used terrestrial target organisms are earthworms and plant seeds and seedlings (Karnak and Hamelink 1982; Wang 1986a; Wang et al. 1990; Callahan et al. 1991; Carlson et al. 1991; Gorsuch et al. 1991). Toxicity testing of soils will employ the soil tests identified in ICF-Kaiser Engineers (1993a), primarily lettuce seed germination and root elongation. For these tests, seeds and seedlings will be grown in soil samples collected from AOCs and

reference sites, and toxicity will be evaluated by comparing seed germination and seedling growth between the AOC and reference sites. 
TABLE 5.2 Summary of Bioassays Selected for Use at J-Field

\begin{tabular}{|c|c|c|}
\hline Test Medium & Organism & Endpoint \\
\hline \multicolumn{3}{|l|}{ Surface Water } \\
\hline Algae & Selenastrum capricornutum & Acute: growth \\
\hline Higher plants & Lemna spp. & $\begin{array}{l}\text { Acute: survival } \\
\text { Chronic: leaf and root growth }\end{array}$ \\
\hline $\begin{array}{l}\text { Freshwater planktonic } \\
\text { invertebrates }\end{array}$ & Daphnia magna & $\begin{array}{l}\text { Acute: survival } \\
\text { Chronic: reproduction }\end{array}$ \\
\hline Freshwater fish & Pimephales promelas & $\begin{array}{l}\text { Acute: survival } \\
\text { Chronic: growth }\end{array}$ \\
\hline Amphibians & Rana spp. (larval) & $\begin{array}{l}\text { Acute: survival } \\
\text { Chronic: growth }\end{array}$ \\
\hline \multicolumn{3}{|l|}{ Sediments } \\
\hline Wetland plants & Sedges & $\begin{array}{l}\text { Acute: germination } \\
\text { Chronic: root and leaf growth }\end{array}$ \\
\hline $\begin{array}{l}\text { Freshwater epibenthic } \\
\text { invertebrates }\end{array}$ & Hyallela azteca & $\begin{array}{l}\text { Acute: survival } \\
\text { Chronic: growth, mobility }\end{array}$ \\
\hline $\begin{array}{l}\text { Freshwater infaunal } \\
\text { invertebrates }\end{array}$ & Chironomus tentans & $\begin{array}{l}\text { Acute: survival } \\
\text { Chronic: growth, mobility, } \\
\text { emergence }\end{array}$ \\
\hline \multicolumn{3}{|l|}{ Soils } \\
\hline Higher plants & Lactuca sativa & $\begin{array}{l}\text { Acute: germination, survival } \\
\text { Chronic: root and shoot } \\
\text { growth }\end{array}$ \\
\hline Soil invertebrates & Harpalus pensylvanicus & Acute: egg mortality \\
\hline Soil invertebrates & Eisenia foetida & $\begin{array}{l}\text { Acute: survival } \\
\text { Chronic: growth }\end{array}$ \\
\hline
\end{tabular}

a Not all bioassays will be used at each AOC.

Source: Modified from ICF-Kaiser Engineers (1993a). 
Acute toxicity of soils will also be evaluated using the soil invertebrate Harpalus pensylvanicus (Carabidae). This species is a common ground beetle that deposits its eggs directly in soil. Eggs are collected from a clean habitat and exposed to AOC soils, reference site soils, and laboratory control soil. Hatching success is then determined after 10 days of exposure. Percent hatching is then compared among the AOC, reference site, and laboratory soils to determine if there is a statistically significant difference in egg hatching success.

The MicroTox Toxicity Test System ${ }^{\mathrm{TM}}$ and associated MicroTox Solid-Phase Test ${ }^{\mathrm{TM}}$ will be used to detect and measure the toxicity of water and sediments, respectively. While not definitive, the MicroTox ${ }^{\mathrm{TM}}$ tests can provide initial screening of media toxicity within a relatively short time (ICF-Kaiser Engineers 1993a, Section 4.3.2.2). An alternative screening test for liquid media will be the Daphnia IQ ${ }^{\mathrm{TM}}$ test. The screening tests completed for the first phase of the study will indicate which media and sites will require refined toxicity tests during later phases of the study.

Soil toxicity screening will be conducted by using an earthworm avoidance test (Yeardley et al. 1994), which is a short-term test (1-3 days) that simultaneously exposes earthworms to potentially contaminated site soils and control (artificial) soils (Warren-Hicks 1989). The test endpoint is avoidance of test soils. In the absence of contaminants, the earthworms should randomly distribute themselves in the test chamber. If the site soils are contaminated, earthworms should avoid contact with the contaminated soils by moving to the uncontaminated artificial soils.

If indicated by the chemical characterization results and toxicity testing, in situ (caged) toxicity tests may be conducted with aquatic biota (e.g., fish, tadpoles, daphnia). In situ toxicity tests of earthworms (Menzie et al. 1992) at upland locations (e.g., upgradient and downgradient of the pits and in pushout areas) may be used to determine the spatial pattern of potential soil toxicity if conditions of soil moisture allow.

\subsubsection{Definitive Toxicity Testing}

For media where acute or chronic toxicity is indicated, additional definitive toxicity testing will be conducted by using similar acute or chronic bioassay methods. However, instead of the contaminated media being used directly, toxicity will be evaluated for a serial dilution of media. The definitive tests thus will generate a dose response curve for the contaminated media of concern and allow identification of the media dilution needed to establish an $\mathrm{LC}_{50}$ value.

\subsection{REFERENCE SITE SELECTION}

Essential to interpretation of endpoints or measurements in a sampling program is selection of appropriate reference sites (Stevens 1988; Hunsaker et al. 1989; Orvos and Cairns 1991). Reference sites should have properties similar to J-Field sites, including topographic conditions, landscape shape and size, soil and sediment properties, salinity levels 
(if aquatic), and habitat type. It is also important that reference sites have the same history of use and disturbance as the J-Field sites, except for the activities that have contaminated J-Field. Reference sites ideally would be completely uncontaminated locations that have habitat characteristics similar to those in potentially contaminated areas of J-Field. However, due to the history of pollution of Chesapeake Bay by a variety of human activities, truly uncontaminated sites are unlikely to exist. It is important that reference sites be uncontaminated by such sources as agricultural, domestic, or industrial drainage. Such contamination could invalidate the comparison.

The J-Field area contains habitats that have been disturbed by noncontaminating activities, as well as habitats that have been relatively undisturbed. The forms of noncontaminating disturbance have included mowing, fire, and excavation. Thus, the ideal reference sites would have both disturbed and undisturbed habitats. The primary objective of the biotic surveys - to determine whether chemical contamination has altered the ecological characteristics of J-Field - can be realized only through the selection of appropriate reference sites. A number of potential aquatic, wetland, and terrestrial reference sites are identified by ICF-Kaiser Engineers (1993a, Tables 4-2 and 4-3). ANL staff will survey these locations, as well as other locations not identified by ICF-Kaiser Engineers (1993a), to determine initial suitability as reference locations for J-Field.

\subsection{SAMPLE LOCATIONS AND NUMBERS}

Sampling for biotic surveys, residual analysis, and toxicity studies will occur in coordination with the sampling of physical media as described in the FSP. Phase 1 of the ERA study will consist of (1) toxicity testing, (2) biotic surveys at J-Field sites and reference sites, and (3) collection during the biotic surveys of biological material for residual analysis. At least one set of biotic surveys and toxicity tests will be performed for each J-Field AOC. Where more than one source of contamination is suspected, such as several burning pits, one suite of biotic surveys and laboratory toxicity tests will be performed for each source. The location(s) chosen for Phase 1 toxicity testing will be the areas of greatest contamination, as indicated by chemical analysis, and known source areas.

In Phase 2 of the ERA, definitive toxicity tests may be performed at each AOC in order to determine the toxicity of contaminated media. Definitive toxicity tests may also be performed to determine the relationship between media contaminant concentrations and observed biological effects. The number and distribution of the definitive toxicity tests to be performed during Phase 2 will depend upon the results of Phase 1 biotic surveys, residual analysis, and toxicity tests, and on the results of the chemical characterization of the site media. Phase 2 testing may not be recommended if, for a media at a site, no observable ecological effects are shown in a contaminated area, no chemical residuals are found in biota, and no toxicity is evident from the acute and chronic toxicity testing. Alternatively, Phase 1 analyses may indicate toxicity or biological effects for a variety of media, and Phase 2 activities would be warranted. The pathway analyses developed in Phase 3 should not require additional field sampling or laboratory analysis. 


\subsubsection{Toxic Burning Pits}

Figures 5.1 and 5.2 show the locations of surface water, sediment, and soil sampling proposed in the FSP for the TBP AOC. Table 5.3 shows the number of physical media samples planned for the RI characterization of the TBP AOC. Media samples for toxicity screening and acute and chronic bioassays will be collected from these same (or as close as possible) locations.

\subsubsection{Biotic Surveys and Samples for Residual Analysis}

All locations used for physical media sampling (Table 5.3) will be flagged so the sampling locations can be identified during the biological surveys. Table 5.4 describes the types of biotic surveys, by habitat type, that will occur at the TBP AOC. Four areas of potential contamination - the VX burning pit, the mustard burning pit, the liquid smoke burning pit, and the pushout area - will be quantitatively surveyed for vegetation, soil invertebrates, soil processes, and small mammals. In addition, two areas at reference sites will be surveyed - one for wooded habitats and one for grassy habitats. Open water habitats and wetland habitats at the TBP AOC will also be quantitatively surveyed for vegetation, benthic macroinvertebrates, and fish. Comparable reference sites will also be surveyed for aquatic and wetland biota. Qualitative surveys for amphibians, reptiles, and birds will be conducted at all suitable habitats. Locations for biotic sampling at the TBP AOC will be selected on the basis of (1) toxicity of physical media, as indicated by toxicity tests; (2) concentrations of chemical contaminants, as indicated by the RI characterization; and (3) location with respect to the pits. Biological samples will be collected during the biotic surveys for analysis of chemical residuals.

\subsubsection{Toxicity Testing}

Acute toxicity testing of surface waters and sediments will be conducted on samples collected from the marsh wetland area surrounding the TBP AOC (Figure 5.1, locations 1 through 11). Chronic toxicity tests will be conducted on samples from those locations where no acute effects are observed. If no acute or chronic effects are observed at a sample location, no further toxicity testing will be conducted. If acute or chronic effects are observed, however, definitive toxicity testing will be conducted on the media of concern. Surface water toxicity test organisms will include algae, the higher plant Lemna, Daphnia, fish, and larval frogs. The measurement endpoints are identified in Table 5.2. Sediment toxicity tests will use Hyallela azteca and possibly Chironomus.

Acute and chronic soil toxicity tests will target higher plants and soil invertebrates, with endpoints of seed germination and ground beetle egg mortality (Table 5.2). Soil samples will be collected from grassland and wooded habitats within the soil sampling area identified in Figure 5.2. Definitive tests will be performed if acute or chronic toxicity of soils is identified. 


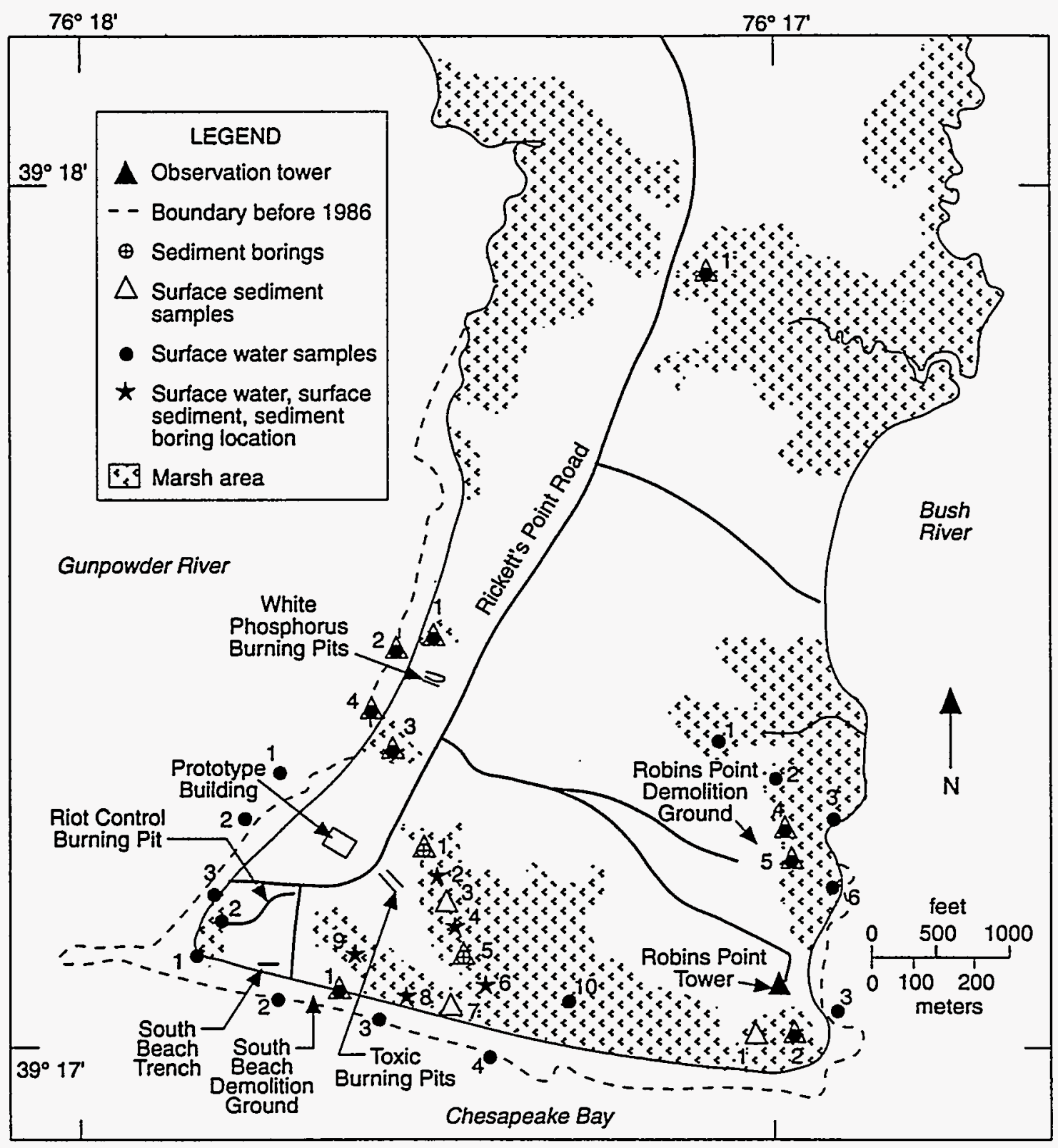

FIGURE 5.1 Proposed Surface Water and Sediment Sampling Sites in the AOCs

\subsubsection{White Phosphorus Burning Pits}

As previously discussed, the WPP AOC is considered an active emergency disposal facility. As a result, the existing pits and areas potentially affected by emergency disposal operations have been excluded from this ERA, and ERA activities of the AOC are deferred pending relocation of the emergency disposal operations. However, aerial photograph interpretations of the WPP AOC indicate that two suspect burning areas may have existed northwest and southwest of the WPP and that a storage area may have existed southeast of the WPP (Figure 5.3). These areas have been identified in the FSP for characterization, and they will also be considered for ecological evaluations. Table 5.3 identifies the approximate 


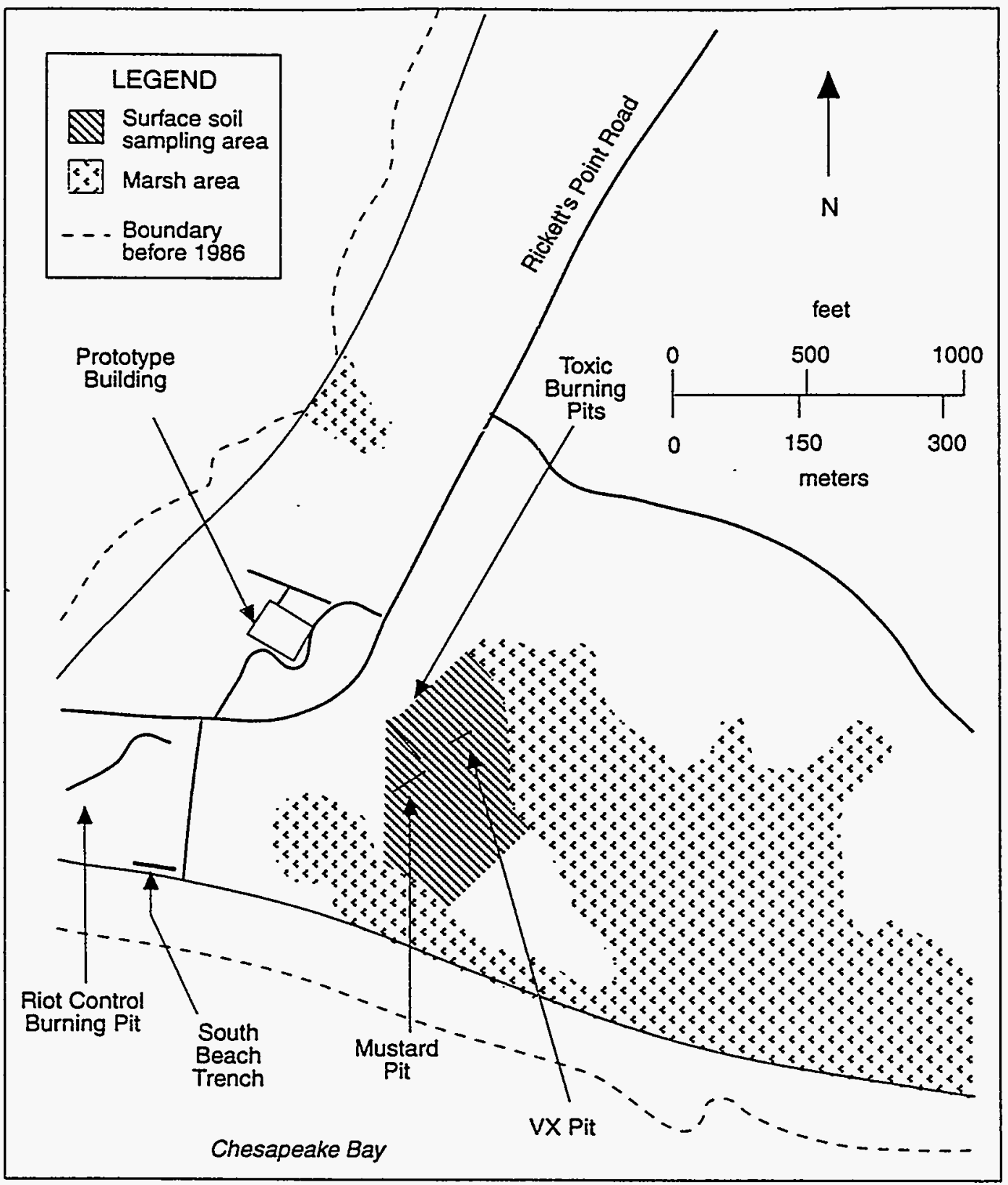

FIGURE 5.2 Surface Soil Sampling Area at the TBP AOC (Source: Adapted from USGS 1991). 
TABLE 5.3 Approximate Numbers of the First Round of Stage I (CWA Screening) Samples Required, by Media and by Area of Concern

\begin{tabular}{|c|c|c|c|c|c|c|}
\hline \multirow[b]{2}{*}{$\mathrm{AOC}$} & \multicolumn{6}{|c|}{ Number of Samples by Media } \\
\hline & $\begin{array}{l}\text { Ground- } \\
\text { water }^{\mathrm{a}}\end{array}$ & $\begin{array}{c}\text { Surface } \\
\text { water }^{a}\end{array}$ & $\begin{array}{c}\text { Surface } \\
\text { Soil }\end{array}$ & $\begin{array}{c}\text { Soil } \\
\text { Boring }\end{array}$ & $\begin{array}{c}\text { Surface } \\
\text { Sediment }\end{array}$ & $\begin{array}{c}\text { Sediment } \\
\text { Boring }\end{array}$ \\
\hline Toxic Burning Pits (TBP) & 21 & 9 & $53(+)^{c}$ & $80^{d}$ & 11 & 35 \\
\hline $\begin{array}{l}\text { White Phosphorus } \\
\text { Burning Pits (WPP) }\end{array}$ & 14 & 5 & $36(+)$ & $32^{\mathrm{e}}$ & 5 & 0 \\
\hline $\begin{array}{l}\text { Riot Control Burning Pit } \\
\text { (RCP) }\end{array}$ & 6 & 7 & 9 & $12^{\mathrm{f}}$ & 0 & 5 \\
\hline Prototype Building (PB) & 1 & 2 & 6 & $6^{\mathrm{g}}$ & 0 & 0 \\
\hline $\begin{array}{l}\text { South Beach Demolition } \\
\text { Ground (SBDG) }\end{array}$ & 1 & 5 & 0 & 0 & 2 & 0 \\
\hline $\begin{array}{l}\text { South Beach Trench } \\
\text { (SBT) }\end{array}$ & 1 & 0 & 4 & 1 & 0 & 0 \\
\hline $\begin{array}{l}\text { Robins Point Demolition } \\
\text { Ground (RPDG) }\end{array}$ & 2 & 7 & 6 & 0 & 3 & 0 \\
\hline $\begin{array}{l}\text { Robins Point Tower Site } \\
\text { (RPTS) }\end{array}$ & 1 & 3 & $8(+)$ & 0 & 3 & 0 \\
\hline Other & 1 & 1 & 0 & 0 & 1 & 0 \\
\hline Opportunity available ${ }^{\mathrm{h}}$ & 0 & 5 & 0 & 0 & 0 & 0 \\
\hline Total (approximate) & 48 & 44 & $122(+)$ & 131 & 25 & 40 \\
\hline
\end{tabular}

a Groundwater and surface water samples will be analyzed for the Contract Laboratory Program Analytical Suite (CLPAS).

b Number assumes five depth intervals sampled per sediment boring.

c The "+" refers to an additional (but unknown) number of samples to be collected.

d Number assumes six depth intervals sampled per boring in the toxic, VX, and mustard pits, and four per boring for the eight other locations.

e Number assumes four depth intervals sampled per boring.

f Number assumes three depth intervals sampled per boring.

g Number assumes six depth intervals sampled per boring (if boring is drilled).

h Surface water that accumulates in the TBP main pits, WPP principal pits, and/or the RCP may be sampled on an opportunity-available basis.

Source: FSP (Benioff et al. 1995b). 
TABLE 5.4 Biotic Surveys Proposed for the Toxic Burning Pits AOC

\begin{tabular}{lccc}
\hline \multicolumn{1}{c}{ Type of Survey } & $\begin{array}{c}\text { Terrestrial } \\
\text { Habitats }\end{array}$ & $\begin{array}{c}\text { Open Water } \\
\text { Habitats }\end{array}$ & $\begin{array}{c}\text { Wetland } \\
\text { Habitats }\end{array}$ \\
\hline Vegetation & $+^{\mathrm{b}}$ & $\mathrm{NA}^{\mathrm{c}}$ & + \\
Soil invertebrate & + & $\mathrm{NA}$ & $\mathrm{NA}$ \\
Soil process & + & $\mathrm{NA}$ & $\mathrm{NA}$ \\
Small mammal & + & $\mathrm{NA}$ & $-{ }^{\mathrm{b}}$ \\
Bird & + & + & + \\
Reptile/amphibian & + & $\mathrm{NA}$ & + \\
Benthic invertebrate & $\mathrm{NA}$ & + & + \\
Fish & $\mathrm{NA}$ & + & $\mathrm{NA}$ \\
\hline
\end{tabular}

a The number of survey transects or grids will vary among survey types and will depend on the nature of the habitat and the extent of known or suspected contamination.

b A " + " indicates survey is planned; a "-" indicates no survey is planned.

c $\mathrm{NA}=$ not applicable.

number of samples, by media, from the WPP AOC proposed for CWA screening and chemical analyses.

\subsubsection{Biotic Surveys and Samples for Residual Analysis}

All locations used for physical media sampling (Table 5.3) will be flagged so the sampling locations can be identified during the biological surveys. Table 5.5 identifies the types of biotic surveys that will occur at the WPP site. Three areas of potential contamination - the northern and southern suspect burning areas and the suspect storage area (Figure 5.3) - will be quantitatively surveyed for vegetation, soil invertebrates, soil processes, and small mammals. There will be no need to resurvey wooded and grassy terrestrial or marsh wetland reference sites because these habitats were surveyed in connection with the survey of the TBP AOC. Qualitative surveys for amphibians, reptiles, and birds will be conducted at each of the three suspect areas of the WPP AOC, and fish surveys will be performed in all aquatic habitats that appear suitable to support fish populations. Locations for biotic surveys at each of the three WPP areas will be selected on 
TABLE 5.5 Biotic Surveys Proposed for the White Phosphorus Burning Pits AOC

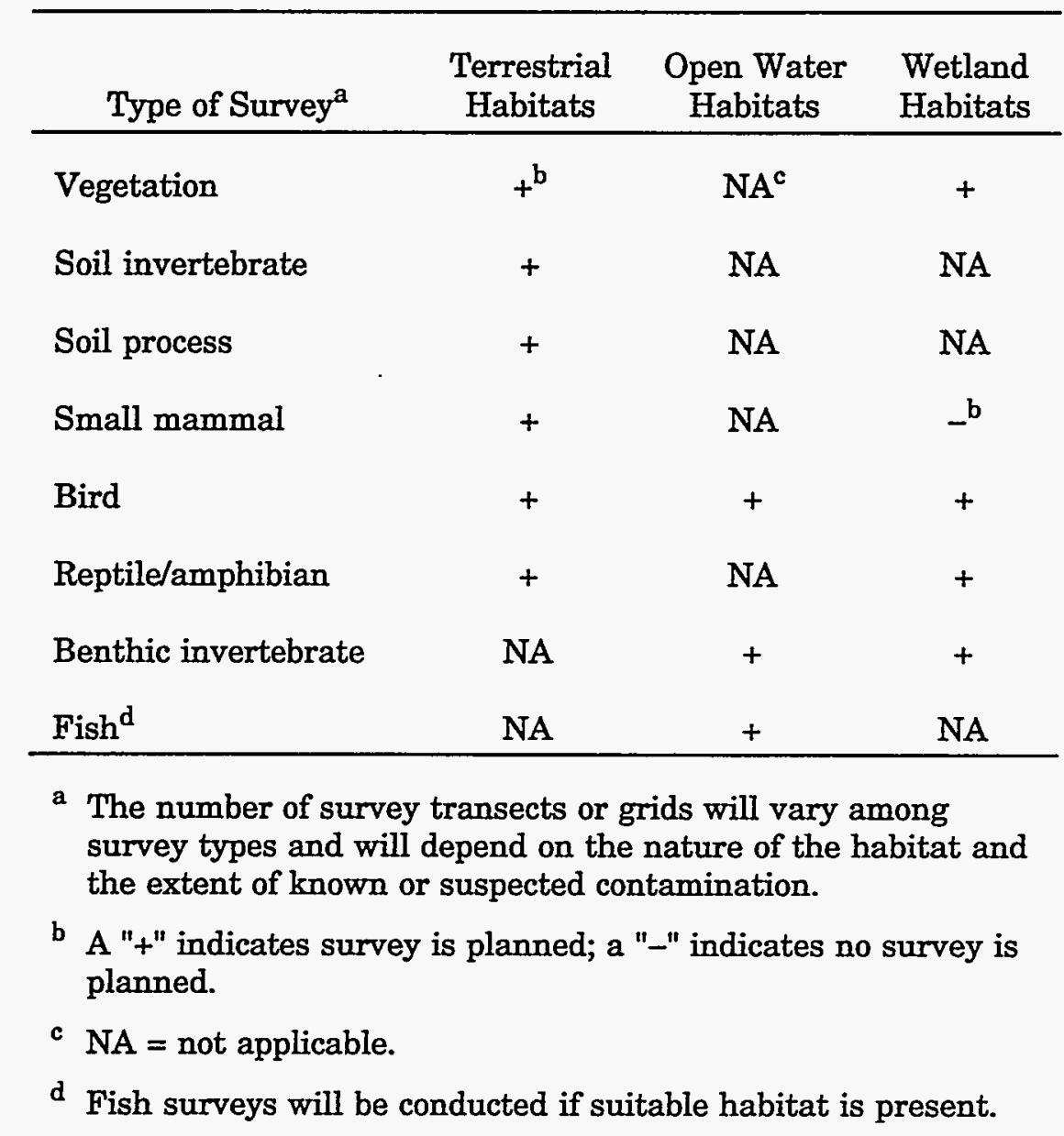

the basis of (1) toxicity of physical media, as indicated by toxicity tests; and (2) concentrations of chemical contaminants, as indicated by the RI characterization. Biological material will be collected during the biotic surveys for analysis of chemical residuals.

\subsubsection{Toxicity Testing}

Acute toxicity testing of surface waters and sediments will be conducted on samples collected from the marsh wetland area within the northern suspect burning area and, if present, from the southern suspect burning area (Figure 5.3). Chronic toxicity tests will be conducted on samples from those locations where no acute effects are observed. If no acute or chronic effects are observed at a sample location, no further toxicity testing will be conducted. If acute or chronic effects are observed, however, definitive toxicity testing will be conducted on the media of concern. Surface water toxicity test organisms will include algae, the higher plant Lemna, Daphnia, fish, and larval frogs. The measurement endpoints are identified in Table 5.2. Sediment toxicity tests will use Hyallela azteca and possibly Chironomus. 


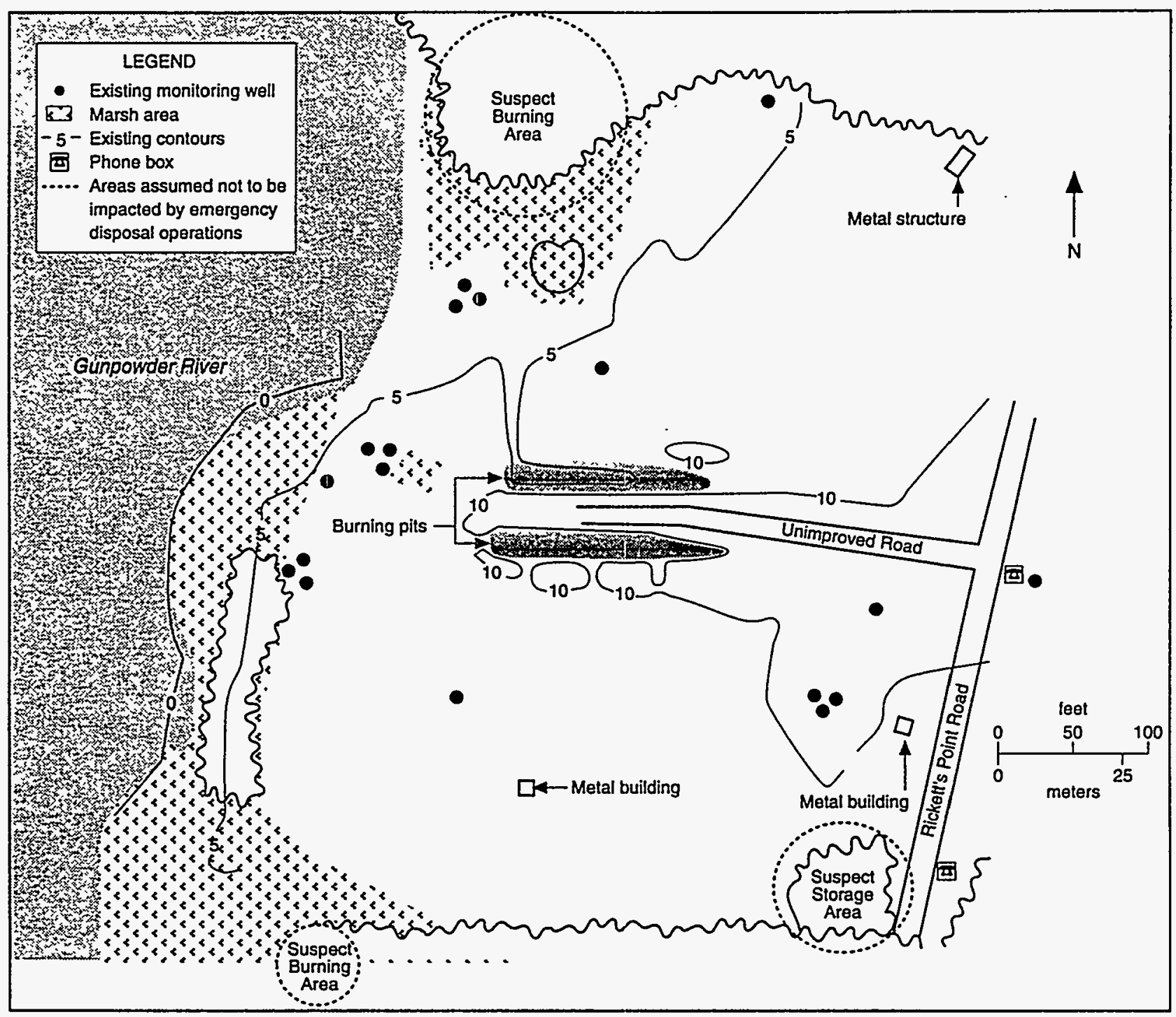

FIGURE 5.3 Surface Soil Sampling Areas at the WPP AOC (Source: Ādapted from Weston 1992)

Acute and chronic soil toxicity tests will target higher plants and soil invertebrates, with endpoints of seed germination and ground beetle egg mortality (Table 5.2). Soil samples will be collected from habitats within the suspect burning areas and the suspect storage area (Figure 5.3). Definitive tests will be performed if acute or chronic toxicity of soils is identified.

\subsubsection{Riot Control Burning Pit}

Sampling locations for chemical characterization of surface water, sediment, and soil at the RCP AOC are shown in Figures 5.1 and 5.4. The number of physical media samples planned for the RI characterization of the RCP AOC are given in Table 5.3. Media samples for toxicity testing will be collected from these same locations (or as close as possible). 


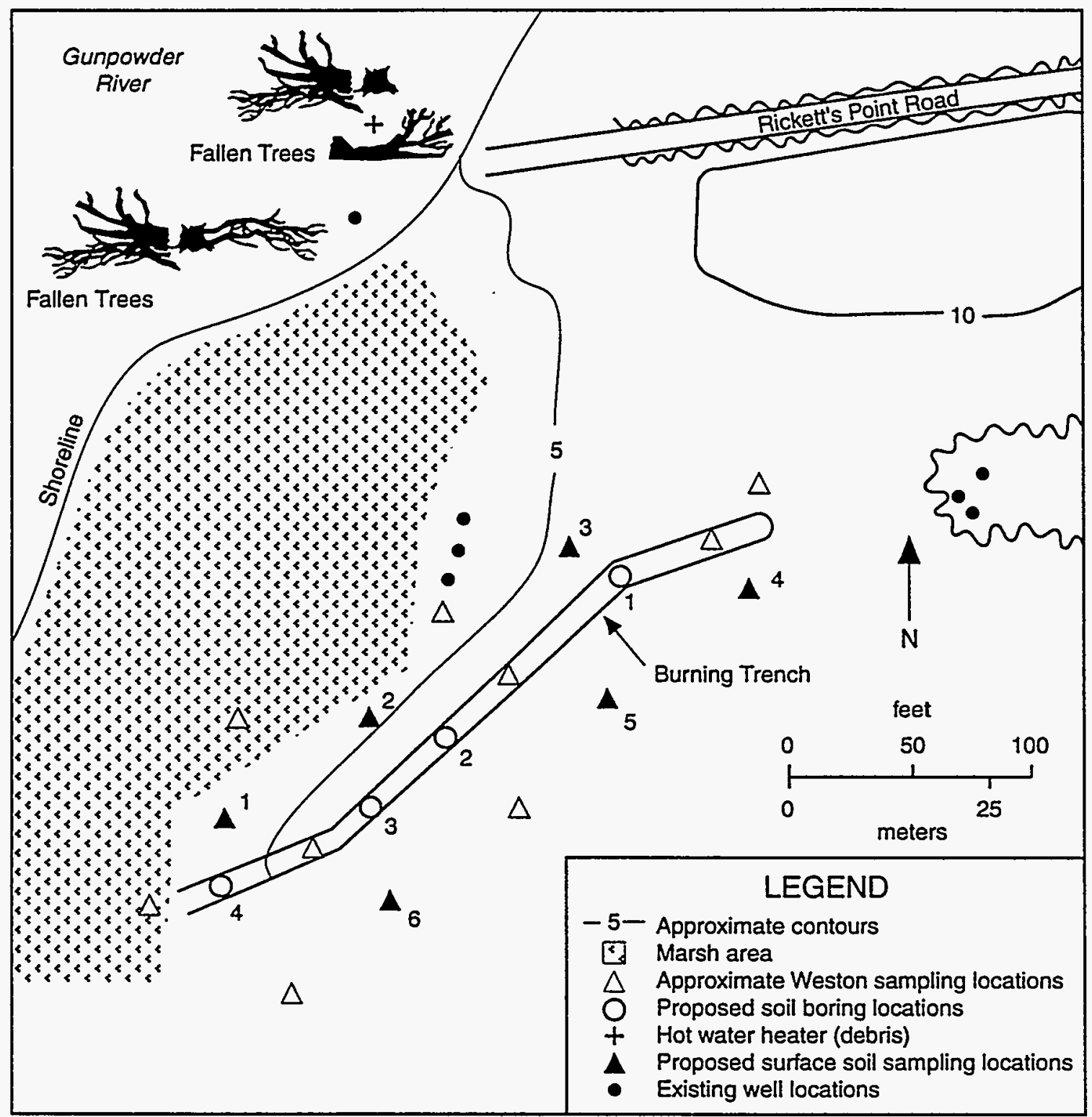

FIGURE 5.4 Soil Sampling Locations at the RCP AOC (Source: Adapted from Weston 1992)

Toxicity screening of surface water will use the MicroTox ${ }^{\mathrm{TM}}$ and Daphnia $\mathrm{IQ}^{\mathrm{TM}}$ testing methods and will focus on the wetland area immediately west of the burning trench (Figure 5.4). Soil toxicity will use the earthworm avoidance test.

\subsubsection{Biotic Surveys and Samples for Residual Analysis}

All locations used for physical media sampling (see Table 5.3) will be flagged so the sampling locations can be identified during the biological surveys. Table 5.6 identifies the types of biotic surveys that will occur at the RCP AOC. One area of potential contamination, the burning trench, will be quantitatively surveyed for terrestrial vegetation, soil 
TABLE 5.6 Biotic Surveys Proposed for the Riot Control Burning Pit AOC

\begin{tabular}{lccc}
\hline \multicolumn{1}{c}{ Type of Survey } & $\begin{array}{c}\text { Terrestrial } \\
\text { Habitats }\end{array}$ & $\begin{array}{c}\text { Open Water } \\
\text { Habitats }\end{array}$ & $\begin{array}{c}\text { Wetland } \\
\text { Habitats }\end{array}$ \\
\hline Vegetation & $+^{\mathrm{b}}$ & $\mathrm{NA}^{\mathrm{c}}$ & + \\
Soil invertebrate & + & $\mathrm{NA}$ & $\mathrm{NA}$ \\
Soil process & + & $\mathrm{NA}$ & $\mathrm{NA}$ \\
Small mammal & + & $\mathrm{NA}$ & $-\mathrm{b}$ \\
Bird & + & - & + \\
Reptile/amphibian & + & $\mathrm{NA}$ & + \\
Benthic invertebrate & $\mathrm{NA}$ & - & + \\
Fish & $\mathrm{NA}$ & - & $\mathrm{NA}$ \\
\hline
\end{tabular}

a The number of survey transects or grids will vary among survey types and will depend on the nature of the habitat and the extent of known or suspected contamination.

b $\mathrm{A}$ "+" indicates survey is planned; a "-" indicates no survey is planned.

c $\mathrm{NA}=$ not applicable.

invertebrates, soil processes, and small mammals. Wetland habitats at the RCP AOC will also be quantitatively surveyed for vegetation and benthic macroinvertebrates. Qualitative surveys for amphibians, reptiles, and birds will be conducted in all habitat types at the RCP AOC. There will be no new surveys of aquatic or terrestrial habitat reference sites, since these habitats were surveyed in connection with the survey of TBP AOC. The location of biotic surveys at the RCP AOC will be selected on the basis of (1) toxicity of physical media, as indicated by toxicity tests; (2) concentrations of chemical contaminants, as indicated by the RI characterization; and (3) location with respect to the trench. Biological material will be collected during the biotic surveys for analysis of chemical residuals.

\subsubsection{Toxicity Testing}

Acute toxicity testing of surface waters and sediments will be conducted on samples collected from the wetland area located west of the trench (Figure 5.4). If present, water from within the trench will also be collected and tested for toxicity. Chronic toxicity tests will be conducted on samples from those locations where no acute effects are observed. If no acute or chronic effects are observed at a sample location, no further toxicity testing will be 
conducted. If acute or chronic effects are observed, however, definitive toxicity testing will be conducted on the media of concern. Surface water toxicity test organisms will include algae, the higher plant Lemna, Daphnia, fish, and larval frogs. The measurement endpoints are identified in Table 5.2. Sediment toxicity tests will use Hyallela azteca and possibly Chironomus.

Acute and chronic soil toxicity tests will target higher plants and soil invertebrates with endpoints of lettuce seed germination and ground beetle egg mortality (Table 5.2). Soil samples will be collected from grassland and forested habitats at the RCP AOC (Figure 5.4). Definitive tests will be performed if acute or chronic toxicity of soils is identified.

\subsubsection{Prototype Building}

Sampling locations for chemical characterization of soil at the PB AOC are shown in Figure 5.5. No surface water or sediment samples will be collected from the PB AOC because no open water or wetland habitats occur at the site. The number of physical media samples planned for the RI characterization of the PB AOC are given in Table 5.3. Soil samples for toxicity testing will be collected from these same locations (or as close as possible).

\subsubsection{Biotic Surveys and Samples for Residual Analysis}

All locations used for physical media sampling will be flagged so the sampling locations can be identified during the biological surveys. Table 5.7 identifies the types of biotic surveys that will occur at the PB AOC. Quantitative surveys will be conducted for terrestrial vegetation, soil invertebrates, soil processes, and small mammals. Qualitative surveys for birds will also be performed. There will be no need to resurvey the terrestrial reference site, since this habitat was surveyed in connection with the survey of the TBP AOC. Locations for the biotic surveys will be selected on the basis of (1) toxicity of physical media as indicated by toxicity tests; and (2) concentration of chemical contaminants, as indicated by the RI characterization. Biological samples will be collected during the biotic surveys for tissue analysis.

\subsubsection{Toxicity Testing}

Because of the absence of open water and wetland habitats at the PB AOC, toxicity testing of surface waters or sediments will not be performed. Acute and chronic toxicity testing will be done for soils and target higher plants and soil invertebrates using the appropriate methods identified in Table 5.2. Soil samples will be collected from locations around the PB and from the two suspect burning areas (Figure 5.5). Definitive tests will be performed if acute or chronic toxicity of soils is identified. 


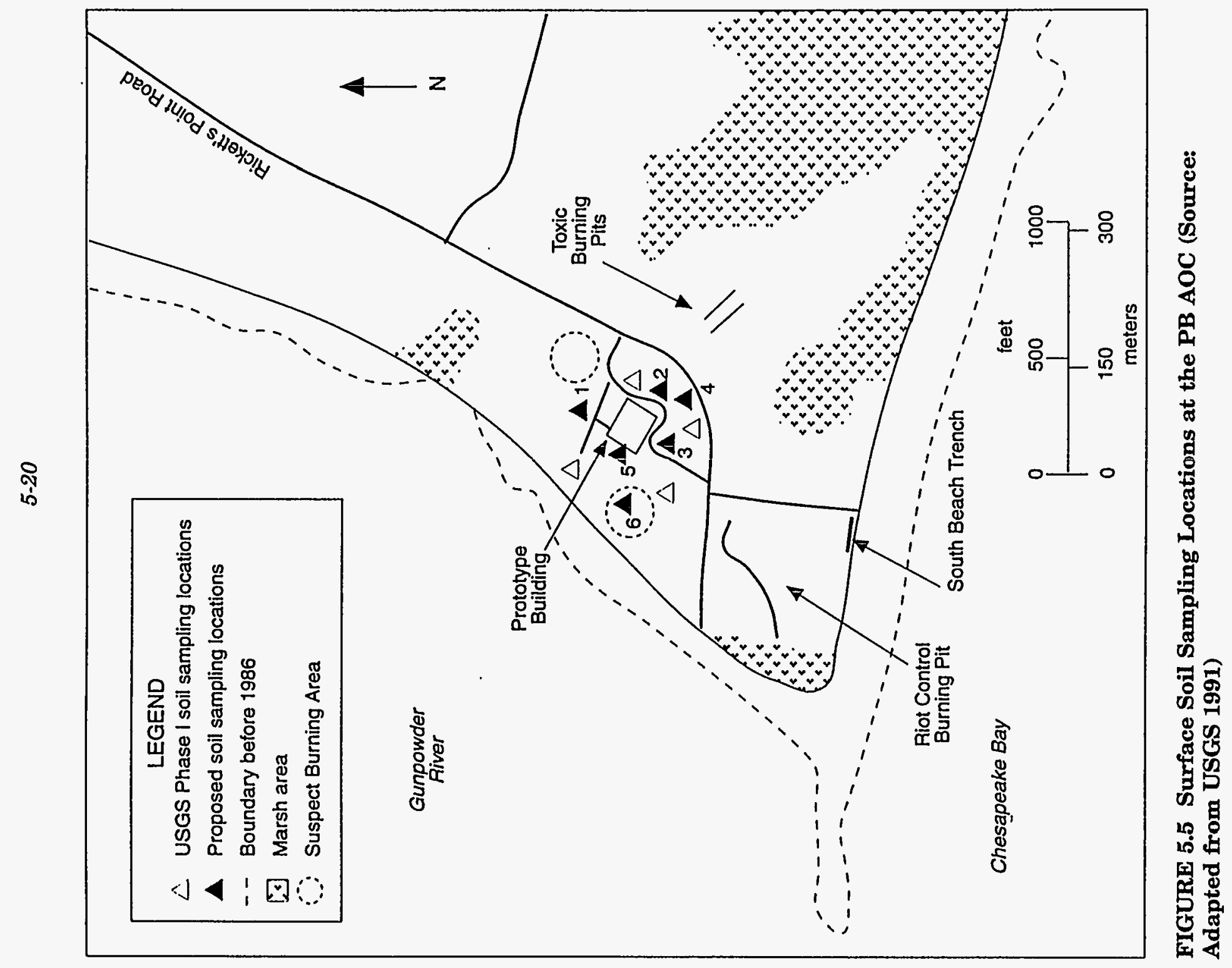


TABLE 5.7 Biotic Surveys Proposed for the Prototype Building AOC

\begin{tabular}{|c|c|c|c|}
\hline Type of Survey ${ }^{a}$ & $\begin{array}{c}\text { Terrestrial } \\
\text { Habitats }\end{array}$ & $\begin{array}{c}\text { Open Water } \\
\text { Habitats }\end{array}$ & $\begin{array}{l}\text { Wetland } \\
\text { Habitats }\end{array}$ \\
\hline Vegetation & $+^{b}$ & $N^{c}$ & $\mathrm{NA}$ \\
\hline Soil invertebrate & + & NA & NA \\
\hline Soil process & + & NA & NA \\
\hline Small mammal & + & NA & NA \\
\hline Bird & + & NA & NA \\
\hline Reptile/amphibian & + & NA & NA \\
\hline Benthic invertebrate & NA & NA & NA \\
\hline Fish & NA & NA & NA \\
\hline
\end{tabular}

a The number of survey transects or grids will vary among survey types and will depend on the nature of the habitat and the extent of known or suspected contamination.

b $A$ "+" indicates survey is planned.

c NA = not applicable.

\subsubsection{South Beach Trench}

Because of the limited previous use of the SBT, media sampling for the RI characterization of the SBT AOC will be limited to soils; surface soils will be collected from two locations within the trench. Soil samples for toxicity testing will be collected from these same locations (or as close as possible). If toxicity is observed for soils from either of these two locations, additional soil samples from around the trench will be collected and tested. No surface water or sediment samples will be collected from the SBT AOC because no open water or wetland habitats occur at the site.

\subsubsection{Biotic Surveys and Samples for Residual Analysis}

The two locations used for soil sampling will be flagged so they can be identified during the biological surveys. Table 5.8 identifies the types of biotic surveys that will occur at the SBT AOC. The trench and its immediate surroundings will be quantitatively surveyed for terrestrial vegetation, soil invertebrates, soil processes, and small mammals. There will be no need to resurvey wooded and grassy terrestrial reference sites since these habitats were 
TABLE 5.8 Biotic Surveys Proposed for the South Beach Trench AOC

\begin{tabular}{lccc}
\hline \multicolumn{1}{c}{ Type of Survey } & $\begin{array}{c}\text { Terrestrial } \\
\text { Habitats }\end{array}$ & $\begin{array}{c}\text { Open Water } \\
\text { Habitats }\end{array}$ & $\begin{array}{c}\text { Wetland } \\
\text { Habitats }\end{array}$ \\
\hline Vegetation & $+^{\mathrm{b}}$ & $\mathrm{NA}^{\mathrm{c}}$ & $\mathrm{NA}$ \\
Soil invertebrate & + & NA & NA \\
Soil process & + & NA & NA \\
Small mammal & + & NA & NA \\
Bird & + & NA & NA \\
Reptile/amphibian & + & NA & NA \\
Benthic invertebrate & NA & NA & NA \\
Fish & NA & NA & NA \\
\hline
\end{tabular}

a The number of survey transects or grids will vary among survey types and will depend on the nature of the habitat and the extent of known or suspected contamination.

b $\mathrm{A}$ "+" indicates survey is planned.

c $\mathrm{NA}=$ not applicable.

surveyed in connection with the survey of the TBP AOC. No open water or wetland habitats are associated with the SBT AOC. Biological material will be collected during the biotic surveys for analysis of chemical residuals.

\subsubsection{Toxicity Testing}

Because of the absence of open water and wetland habitats at the SBT AOC, toxicity testing of surface waters or sediments will not be performed. Acute and chronic toxicity testing will be done for soils and target higher plants and soil invertebrates using the appropriate methods identified in Table 5.2. Soil samples for testing will be collected from two locations within the trench. If the results of these tests are positive, additional samples may be collected from areas around the trench. Definitive tests will be performed if acute or chronic toxicity of soils is identified. 


\subsubsection{South Beach Demolition Ground}

The SBDG AOC is currently located offshore of J-Field and is exposed only during periods of low tide. As a consequence, soils are not a media of concern for this AOC. Additional estuarine sediment samples are not proposed for the SBDG, pending evaluation of previously collected sediment data from this AOC. If indicated by the previously collected sediment data, toxicity testing may be implemented at the SBDG AOC. During a recent site visit, ANL staff located a large pit, about $12 \mathrm{ft}$ deep and $25 \mathrm{ft}$ across, in the trees located just onshore of the SBDG. This pit appears to be the remnant of a high-explosive demolition crater. The FSP identifies the sediment and surface water sampling planned for this crater.

\subsubsection{Biotic Surveys and Samples for Residual Analysis}

All sediment and surface water sampling locations within the crater will be flagged so the sampling locations can be identified during the biological surveys. Table 5.9 describes the types of biotic surveys that will occur at the SBDG AOC. No areas of potential terrestrial

TABLE 5.9 Biotic Surveys Proposed for the South Beach Demolition Ground AOC

\begin{tabular}{lccc}
\hline \multicolumn{1}{c}{ Type of Survey } & $\begin{array}{c}\text { Terrestrial } \\
\text { Habitats }\end{array}$ & $\begin{array}{c}\text { Open Water } \\
\text { Habitats }\end{array}$ & $\begin{array}{c}\text { Wetland } \\
\text { Habitats }\end{array}$ \\
\hline Vegetation & NA $^{\mathrm{b}}$ & NA & NA \\
Soil invertebrate & NA & NA & NA \\
Soil process & NA & NA & NA \\
Small mammal & NA & NA & NA \\
Bird & NA & $+^{c}$ & NA \\
Reptile/amphibian & NA & NA & NA \\
Benthic invertebrate & NA & $-{ }^{c}$ & - \\
Fish & NA & - & NA \\
\hline
\end{tabular}

a The number of survey transects or grids will vary among survey types and will depend on the nature of the habitat and the extent of known or suspected contamination.

b $\mathrm{NA}=$ not applicable.

c $A$ "+" indicates survey is planned; a "-" indicates survey is not planned.

d The detonation crater will be surveyed for amphibians. 
contamination are known for the SBDG, since the site is located in the nearshore open water of Chesapeake Bay. Open water habitats will be qualitatively surveyed for birds. Because of the potential for the detonation crater to serve as a breeding and nursery habitat for local amphibian populations, the crater will be qualitatively surveyed in spring and early summer for adult or juvenile amphibians or egg masses. No other surveys are planned for the detonation crater. No tissue collection for residue analysis is currently planned for the SBDG AOC.

\subsubsection{Toxicity Testing}

Acute toxicity testing of surface waters and sediments will be conducted on samples collected from the detonation crater. Chronic toxicity tests will be conducted on samples from those locations where no acute effects are observed. If no acute or chronic effects are observed at a sample location, no further toxicity testing will be conducted. If acute or chronic effects are observed, however, definitive toxicity testing will be conducted on the media of concern. Surface water toxicity test organisms will include algae, the higher plant Lemna, Daphnia, and larval frogs. The measurement endpoints will be those identified in Table 5.2. Sediment toxicity tests will use Hyallela azteca and possibly Chironomus.

\subsubsection{Robins Point Demolition Ground}

Figures 5.1 and 5.6 show the surface water, sediment, and surface soil sampling locations proposed for the RPDG AOC. Because the area of the RPDG west of the berm (Figure 5.6) is currently used for emergency disposal activities, sampling for toxicity tests and biotic surveys will be limited to wetland and grassland habitats located east of the berm. Table 5.3 shows the number of media samples planned for the RI characterization of the RPDG. Media samples for toxicity testing will be collected from these same locations (or as close as possible).

\subsubsection{Biotic Surveys and Samples for Residual Analysis}

All locations used for physical media sampling will be flagged so the sampling locations can be identified during the biological surveys. Table 5.10 identifies the types of biotic surveys that will occur at the RPDG AOC. Terrestrial habitats will be quantitatively surveyed for vegetation, soil invertebrates, soil processes, and small mammals. Wetland habitats will be quantitatively surveyed for aquatic vegetation and benthic macroinvertebrates. No additional aquatic or terrestrial reference sites will be needed. Terrestrial and aquatic habitats will be qualitatively surveyed for amphibians, reptiles, and birds. Locations for biotic surveys will be selected on the basis of (1) toxicity of physical media, as indicated by toxicity tests; (2) concentration of chemical contaminants, as indicated by the RI characterization; and (3) location with respect to the demolition grounds. During the biotic surveys, biological material will be collected for tissue residue analysis. 


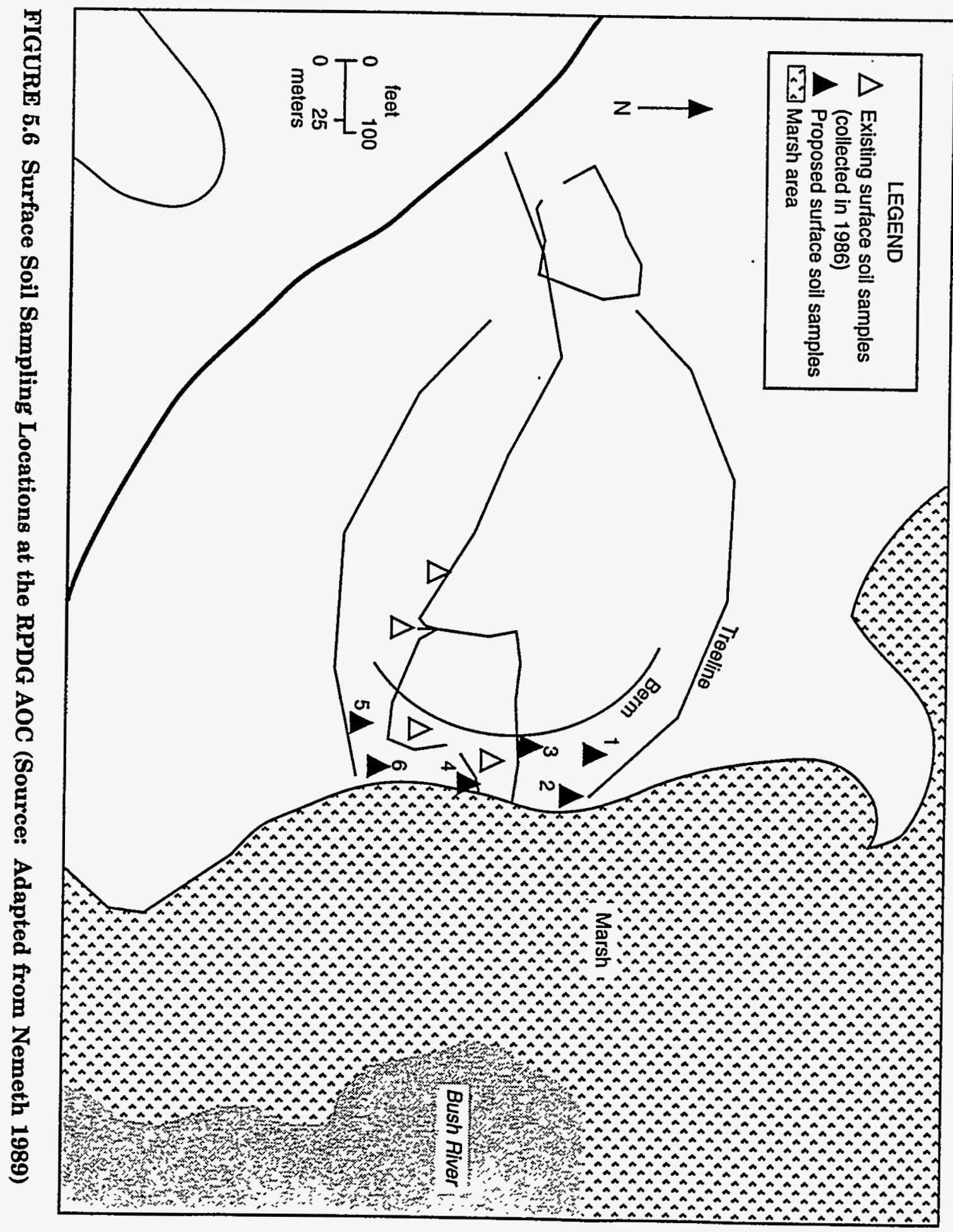


TABLE 5.10 Biotic Surveys Proposed for the Robins Point Demolition Ground AOC

\begin{tabular}{lccc}
\hline \multicolumn{1}{c}{ Type of Survey } & $\begin{array}{c}\text { Terrestrial } \\
\text { Habitats }\end{array}$ & $\begin{array}{c}\text { Open Water } \\
\text { Habitats }\end{array}$ & $\begin{array}{c}\text { Wetland } \\
\text { Habitats }\end{array}$ \\
\hline Vegetation & $+^{\mathrm{b}}$ & $\mathrm{NA}^{\mathrm{c}}$ & + \\
Soil invertebrate & + & $\mathrm{NA}$ & $\mathrm{NA}$ \\
Soil process & + & $\mathrm{NA}$ & $\mathrm{NA}$ \\
Small mammal & + & $\mathrm{NA}$ & $-{ }^{\mathrm{b}}$ \\
Bird & + & $\mathrm{NA}$ & + \\
Reptile/amphibian & + & $\mathrm{NA}$ & + \\
Benthic invertebrate & $\mathrm{NA}$ & $\mathrm{NA}$ & + \\
Fish & $\mathrm{NA}$ & $\mathrm{NA}$ & $\mathrm{NA}$ \\
\hline
\end{tabular}

a The number of survey transects or grids will vary among survey types and will depend on the nature of the habitat and the extent of known or suspected contamination.

b $\mathrm{A}^{\text {"+" }}$ indicates survey is planned; a "-" indicates survey is not planned.

c NA = not applicable.

\subsubsection{Toxicity Testing}

Acute toxicity testing of surface waters and sediments will be conducted on samples collected from the wetland area east of the berm (Figure 5.6). Chronic toxicity tests will be conducted on samples from those locations where no acute effects are observed. If no acute or chronic effects are observed at a sample location, no further toxicity testing will be conducted. If acute or chronic effects are observed, however, definitive toxicity testing will be conducted on the media of concern. Surface water toxicity test organisms will include algae, the higher plant Lemna, Daphnia, and larval frogs. The measurement endpoints are identified in Table 5.2. Sediment toxicity tests will use Hyallela azteca and possibly Chironomus.

Acute and chronic soil toxicity tests will target higher plants and soil invertebrates, with endpoints of seed germination and ground beetle egg mortality (Table 5.2). Soil samples will be collected from habitats between the wetland and the berm (Figure 5.6). Definitive tests will be performed if acute or chronic toxicity of soils is identified. 


\subsubsection{Robins Point Tower Site}

Figures 5.1 and 5.7 show the locations of surface water, sediment, and soil sampling proposed for the RPTS AOC. Soil samples for toxicity testing will be collected for the surface soil sampling area identified in Figure 5.7, while surface water and sediment samples for toxicity testing will be collected from the wetland area immediately south of the soil sampling area. Media for toxicity testing will be collected from the same locations (or as close to as possible) as those used for the RI characterization.

\subsubsection{Biotic Surveys and Samples for Residual Analysis}

All locations used for physical media sampling will be flagged so the sampling locations can be identified during the biological surveys. Table 5.11 identifies the types of biotic surveys that will occur at the RPTS AOC. Terrestrial habitats will be quantitatively surveyed for vegetation, soil invertebrates, soil processes, and small mammals. Wetland habitats will be quantitatively surveyed for vegetation and benthic macroinvertebrates. Terrestrial and aquatic habitats will also be qualitatively surveyed for amphibians, reptiles, and birds. There will be no need to resurvey terrestrial or aquatic reference sites, since these habitats were surveyed in connection with the survey of TBP. Locations for biotic surveys will be selected on the basis of (1) toxicity of physical media, as indicated by toxicity tests; and (2) concentrations of chemical contaminants, as indicated by the RI characterization. During the biotic surveys, biological material will be collected for tissue residue analysis.

\subsubsection{Toxicity Testing}

Acute toxicity testing of surface waters and sediments will be conducted on samples collected from the wetland area south of the RPTS (Figure 5.7). Chronic toxicity tests will be conducted on samples from those locations where no acute effects are observed. If no acute or chronic effects are observed at a sample location, no further toxicity testing will be conducted. If acute or chronic effects are observed, however, definitive toxicity testing will be conducted on the media of concern. Surface water toxicity test organisms will include algae, the higher plant Lemna, Daphnia, and larval frogs. The measurement endpoints for the various toxicity tests are identified in Table 5.2. Sediment toxicity tests will use Hyallela azteca and possibly Chironomus.

Acute and chronic soil toxicity tests will target higher plants and soil invertebrates, with endpoints of seed germination and ground beetle egg mortality (Table 5.2). Soil samples will be collected from within the surface soil sampling area identified in Figure 5.7. Definitive tests will be performed if acute or chronic toxicity of soils is identified.

\subsubsection{Other J-Field Sites}

Pursuant to the requests of the $\mathrm{MDE}$, characterization activities have been expanded beyond the eight specified AOCs to include all of J-Field. As a result, a review of archival 


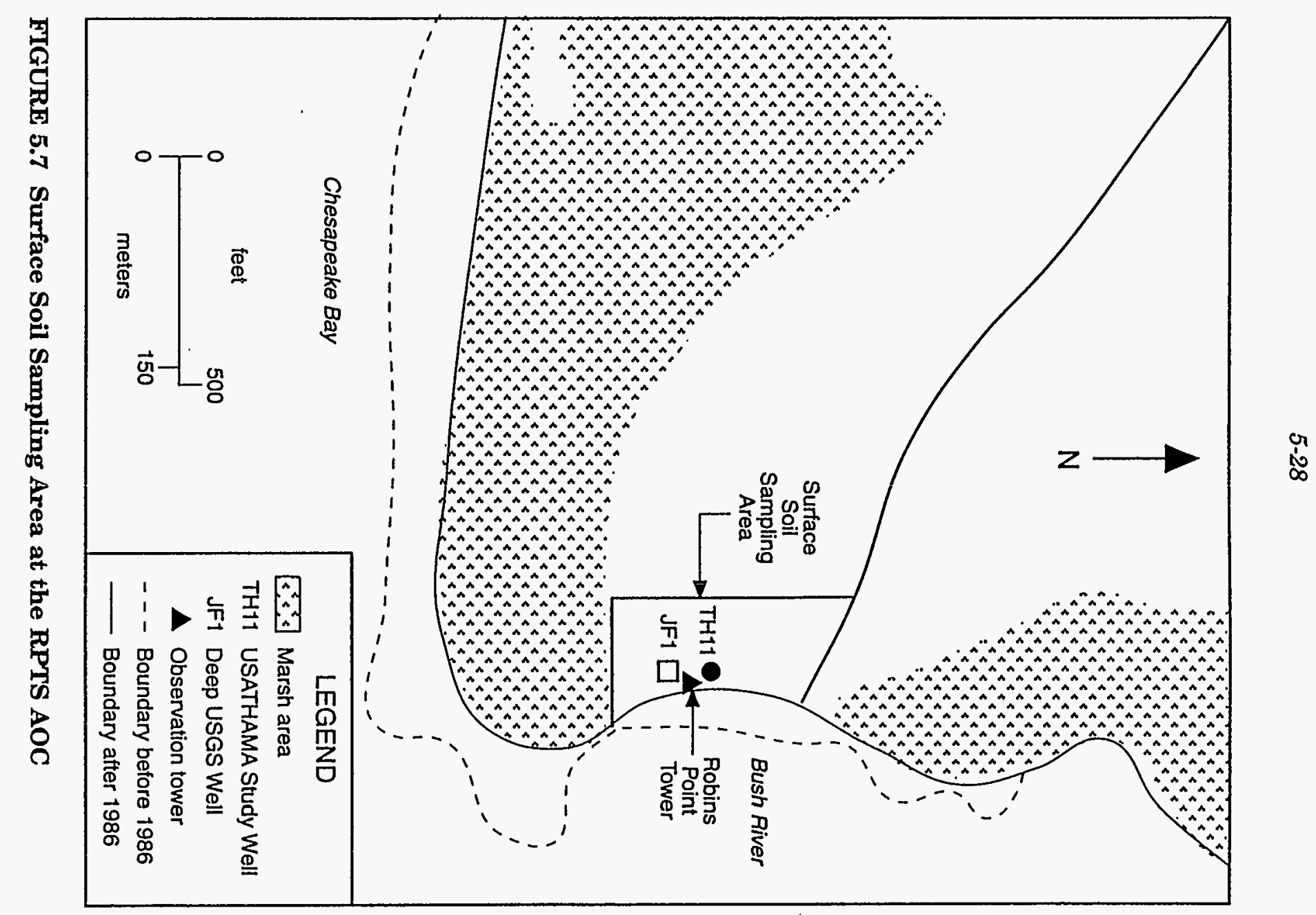


TABLE 5.11 Biotic Surveys Proposed for the Robins Point Tower Site AOC

\begin{tabular}{lccc}
\hline \multicolumn{1}{c}{ Type of Survey } & $\begin{array}{c}\text { Terrestrial } \\
\text { Habitats }\end{array}$ & $\begin{array}{c}\text { Open Water } \\
\text { Habitats }\end{array}$ & $\begin{array}{c}\text { Wetland } \\
\text { Habitats }\end{array}$ \\
\hline Vegetation & $+^{\mathrm{b}}$ & $\mathrm{NA}^{\mathrm{c}}$ & + \\
Soil invertebrate & + & $\mathrm{NA}$ & $\mathrm{NA}$ \\
Soil process & + & $\mathrm{NA}$ & $\mathrm{NA}$ \\
Small mammal & + & $\mathrm{NA}$ & $-\mathrm{b}$ \\
Bird & + & $\mathrm{NA}$ & + \\
Reptile/amphibian & + & $\mathrm{NA}$ & + \\
Benthic invertebrate & $\mathrm{NA}$ & $\mathrm{NA}$ & + \\
Fish & $\mathrm{NA}$ & $\mathrm{NA}$ & $\mathrm{NA}$ \\
\hline
\end{tabular}

a The number of survey transects or grids will vary among survey types and will depend on the nature of the habitat and the extent of known or suspected contamination.

b $A$ " + " indicates survey is planned; a "-" indicates survey is not planned.

c NA = not applicable.

information and walkover surveys were conducted to identify suspect areas at J-Field. These suspect areas are referred to as potential areas of concern (PAOCs), and the results of the review and walkover survey are presented in Appendix B of the FSP. Appendix B of the FSP also presents the methodology used to identify the PAOCs and presents the media sampling that is planned to further characterize the nature and extent of contamination at the PAOCs.

With the exception of the bomb craters at J-Field, no biotic surveys, toxicity testing, tissue residue analysis, or uptake modeling is planned at this time for the PAOCs. Instead, the results of the characterization activities at the PAOCs will be compared to the contaminant characterization and ecological assessment results for the principle AOCs at J-Field to determine if specific ERA activities, such as biotic surveys and acute and chronic toxicity testing, are warranted.

In addition to the planned PAOC characterization activities identified in the FSP, a contaminant characterization program has been developed to specifically evaluate the potential for contamination of bomb craters at J-Field. Based upon reviews of historic aerial photographs and observations by field personnel, there are hundreds of bomb craters present at J-Field. Although there is limited information about the contamination present in such 
craters, each of these bomb craters could serve as a potential source of contamination. Although the craters may be dry for much of the year, they often fill with water in the spring as a result of snowmelt and spring rains, thus forming temporary, fishless ponds. Many of the amphibian species present at APG (e.g., upland chorus frog, marbled and spotted salamanders, green treefrog, and northern cricket frog) are known to utilize or exclusively rely upon ephemeral fishless bodies of water for reproduction. If contamination is present in the craters, these potential breeding sites could pose a significant risk to the survival of amphibian populations. It is unknown at this time to what extent, if any, local amphibian populations actually utilize site craters for reproduction.

A bomb crater characterization program is presented in Appendix B of this ERA. The program focuses primarily on metal contamination of the sediment and surface water in the craters; approximately $25 \%$ of the craters will be sampled for explosives and their degradation products. The craters will be qualitatively surveyed for amphibians in spring and early summer. Survey methods will include vocalizations and collection and identification of individuals. If egg masses are found, the craters containing the eggs will be flagged and monitored to evaluate relative hatching success. The results of the chemical characterization will be screened against available toxicity data (such as Devillers and Exbrayat 1992) and compared to the RI and ERA results for the principle AOCs at J-Field. Toxicity testing may be implemented if contaminant concentrations are detected during field surveys at levels that have exhibited toxicity at other AOCs, that exceed published toxicity values, or that indicate adverse ecological effects such as mortality of adults or failure of successful egg hatching. 


\section{RECORDS MANAGEMENT}

\subsection{QUALITY ASSURANCE/QUALITY CONTROL MEASURES}

The EPA requires all its laboratories, program offices, and regional offices to participate in a QA program. The EPA policy applies to all environmental sampling, monitoring, and measurement efforts supported by EPA or mandated through contracts, regulations, or formal agreements. The EPA recommends that a formal QA plan be developed for all data-generating activities associated with ecological assessments at hazardous waste sites (EPA 1989a).

The QA measures identified in this work plan include all aspects of laboratory and field procedures that affect the accuracy and precision of the data, including the collection and handling of soil, sediment, and biological samples; the source and condition of all test organisms; the condition of all sampling and test equipment; instrument calibration; sample replicates and controls; record keeping; and data analysis and evaluation. The QA procedures include the maintenance of chain of custody, the collection of QA samples, and the documentation of collection and analytical procedures. Appropriate data QA/QC measures will be followed, as outlined in ICF-Kaiser Engineers (1992).

\subsection{TECHNICAL DATA MANAGEMENT}

Figure 6.1 illustrates the data flow for the J-Field ERA project. Details for each step in the flow diagram are as follows:

1. Following collection of field or laboratory data, the data will be forwarded to the ERA data manager. The data manager will log in the receipt of the data.

2. The data will be entered into a database and will undergo a preliminary check by the QA officer. Provisional data summaries will be prepared for distribution to ERA team members.

3. The provisional data will be distributed to ERA team members, and the data manager will record the date of data distribution.

4. The data will undergo a QA/QC review by the QA officer or designee(s), who will check that $\mathrm{QC}$ procedures have been followed and will perform a quality check of the provisional data. Any errors detected will be highlighted and corrections will be made, if appropriate. The person performing the QA/QC review will prepare a report detailing the results of the review and noting any discrepancies, errors, or corrections. This report will be filed in the project $\mathrm{QA}$ records. 


\section{Field and Laboratory Data}

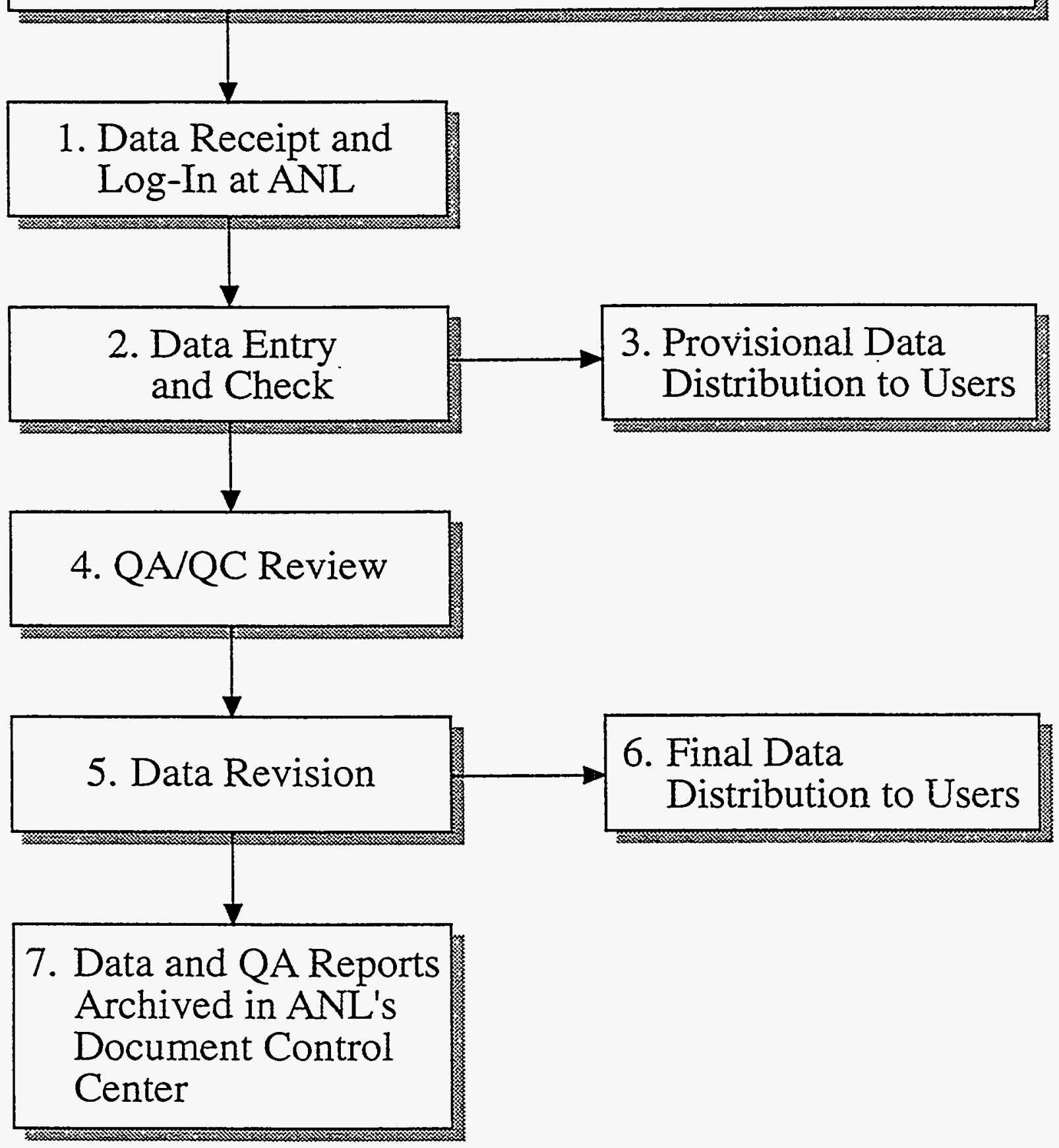

FIGURE 6.1 Overview of Data Flow for the J-Field ERA Project 
5. The data will be revised accordingly and forwarded to the data manager, who will update the database.

6. The data manager will distribute the updated data to ERA team members.

7. The data and the QA reports will be archived in ANL's Document Control Center, and the data manager will maintain a hard copy index of the hard copy data files.

\subsection{TECHNICAL SUPPORT AND FACIIITIES}

Subcontractors will be employed to perform field sampling and laboratory analyses. These subcontractors will be required to prepare an approved work plan (including QA/QC procedures). Depending on the medium and contaminant concentrations involved, certain laboratory analyses will be completed at the U.S. Army's Surety Screening Laboratory at APG. Additional support in the form of physical space at APG for ANL investigators and other personnel, as well as necessary capital, will be required for the efficient completion of this ERA. 
6-4 


\section{DATA PRESENTATION, ANALYSIS, AND INTERPRETATION}

\subsection{INTRODUCTION}

Upon completion of Phase 1, 2, and 3 activities, the risk to ecological resources from contamination will be evaluated for each $\mathrm{AOC}$ and the entire J-Field site. This approach will permit evaluation of the contribution of each AOC to the overall ecological risk identified for J-Field. For some wide-ranging receptors (such as the red-tailed hawk), ecological risks may only be estimated by considering multiple AOCs. In contrast, risks to receptors with small home ranges (such as the white-footed mouse) or to sessile receptors (such as vegetation) will be limited to individual AOCs. By evaluating each AOC individually, remedial activities, if needed, can be targeted on those AOCs with the greatest contribution to the predicted ecological risk at J-Field.

This ERA represents the ecological component of the CERCLA baseline risk assessment and thus provides an evaluation of a no-action remedial alternative for the entire J-Field site and each AOC. The ERA follows the overall format of the EPA framework for ecological risk assessment (EPA 1992b) and will present the four components of the framework: (1) problem formulation, (2) exposure assessment, (3) effects assessment, and (4) risk characterization. This format also follows the general format identified for use in all human and ecological risk assessments at the APG (ICF-Kaiser Engineers 1993a). The ERA will present a description of the current environmental setting at each AOC and the entire J-Field site and will summarize the results of the sitewide RI characterization activities currently under way at J-Field, as well as pertinent results from previous studies (Section 2).

\subsection{DESCRIPTION OF CURRENT SITE CONDITIONS}

The current environmental setting will be described for the entire J-Field site and for each AOC. The descriptions will be based largely on biological data collected during the Phase 1 activities of the ERA and on physical and chemical data collected as part of the RI characterization of J-Field. The descriptions will include information on the physical, chemical, and biological components of the environment. A final site conceptual model will also be presented.

Summary chemical data will be provided, by medium, for each AOC. The mean concentration, range, and detection frequency will be presented for contaminants at each $A O C$ and the reference sites. Contaminants of concern will be identified following the approach presented in Section 3 of this work plan. Noncontaminant chemical data, such as alkalinity, $\mathrm{pH}$, dissolved oxygen of surface waters, and total organic content of soils, will also be presented.

Habitat and species data collected primarily during Phase 1 of the ERA will be summarized by AOC. For each AOC, habitat data will include habitat type and size in hectares (ha), and biota data will include species occurrence and abundance. Species or 
habitats of special interest (threatened or endangered species, breeding grounds) will be highlighted. Avian species will be categorized with regard to their status as resident, transient, breeding, threatened or endangered, or other designation, as appropriate.

Habitat maps will be generated through GIS analyses to provide the following information:

- The locations and shape of open water and tidal and nontidal wetlands, woodland habitats, and grassland habitats (these maps will be cross-referenced to tables containing areal data for each habitat); and

- The locations of state or federal species and habitats of special interest.

Additional maps will be prepared showing all chemical and biological sampling locations and all areas identified as contaminated by the RI characterization.

\subsection{EXPOSURE ASSESSMENT}

The exposure assessment will estimate actual or potential exposure of the ecological receptors at each AOC and for all of J-Field. The assessment will be based on three approaches: (1) comparison of the distribution and home range of ecological receptors to the areal extent of contamination, (2) tissue concentrations, and (3) dose estimates to receptors on the basis of contaminant concentrations in food and media.

In the first approach, potential exposure is estimated as the percent contribution of the areal extent of contamination to the known home range of the ecological receptor. If the areal extent of contamination is greater than the home range for a receptor, potential exposure would be estimated as $100 \%$. For example, the red-tailed hawk may have a home range of 50 ha (123 acres). Potential exposure to contaminants at the 3.6 ha (9 acres) TBP AOC would be estimated to be $7.2 \%$. In contrast, the American goldfinch, with a home range of about 0.06 ha $(0.16$ acre), would have an estimated exposure of $100 \%$.

The second approach uses tissue residue analyses to quantify actual exposure and uptake by site biota. The results of tissue residue analyses for biota collected from AOCs and reference sites will be presented as the mean and range of contaminant concentration per gram tissue weight for each species for which such analyses are made. These data will be used to quantify, by AOC, actual exposure of selected biota. Data on residual tissue concentrations will also be presented in a graphical format showing the locations of biota with elevated tissue concentrations.

The final approach to estimating exposure uses species-specific estimates of contaminant uptake. The Phase 3 pathway analysis will provide estimates of applied daily dose (ADD) for higher trophic level receptors for which tissue sampling is not practical or is 
prohibited. The ADD will be estimated following EPA guidance (EPA 1993) using the general formula:

$$
A D D=(C \times I R \times E D) /(B W \times E D),
$$

where

$$
\begin{aligned}
A D D & =\text { applied daily dose (expressed as mg contaminant/kg body weight per day); } \\
C & =\text { contaminant concentration in media; } \\
I R & =\text { intake rate of the media; } \\
E D & =\text { exposure duration; and } \\
B W & =\text { body weight of the receptor. }
\end{aligned}
$$

For each receptor, ADDs will be estimated by incorporating home range and site use information and will include drinking water, dietary, and soil and sediment ingestion exposure pathways as appropriate. Tissue residue analyses results will be used to provide site-specific transfer factors between trophic levels and to provide concentrations for selected food items. The ADD may also be estimated by considering dermal and inhalation exposure routes.

An exposure profile will be presented for each ecological receptor. This profile will identify the parameters and assumptions used in estimating the ADD. These parameters will include home range, body weight, diet composition, water ingestion rate, and ingestion rates for different diet fractions. Exposure factors will be developed using (1) the results of the biotic surveys conducted during Phase 1 of the ERA, (2) the wildlife exposure factors compiled by the EPA (1993), and (3) data from the open scientific literature.

Conceptual exposure pathways will be presented in graphical format for each receptor. The software package STELLA ${ }^{\mathrm{TM}}$ will be used to develop mathematical algorithms for describing the movement of contaminants between compartments along each pathway (e.g., soil to vegetation to insects to ecological receptor) and to the final receptor. The mathematical algorithms, along with all assumptions, will be presented for each exposure pathway.

For the exposure assessment, a total $\mathrm{ADD}$ from all exposure pathways (drinking water, soil ingestion, etc.) will be estimated for each receptor at each AOC. For wide-ranging species, the ADD will be calculated using exposure pathways from multiple AOCs. Estimation of the ADD will be performed using the food chain and exposure pathway models developed during Phase 3 of the ERA. Monte Carlo simulations will be applied to the exposure scenarios for each ecological receptor to evaluate the uncertainty associated with the exposure pathway modeling. Sensitivity analyses will be performed to evaluate the importance of each exposure parameter in estimating the ADD, and the results of the analyses will be presented in tabular format. 


\subsection{EFFECTS ASSESSMENT}

The effects assessment, as identified in the EPA framework for ERAs (EPA 1992b), is analogous to the toxicity assessment conducted in human health risk assessments. The effects assessment will be conducted largely on the basis of the field studies and toxicity testing results obtained from Phases 1 and 2 of the ERA. Field studies and toxicity testing are two of the major approaches used in performing effects assessments (EPA 1992b).

\subsubsection{Field Studies}

The results of the field studies, including biosurveys and investigations of soil processes, will be used to document actual ecological effects at each AOC. The data obtained from the field studies will include the following:

- Estimates of species richness, diversity, similarity, and biomass;

- The presence or absence of tolerant and sensitive species;

- Estimates of population and community composition; and

- Estimates of soil process rates, such as nitrogen mineralization and litter decomposition.

These data will be presented for each AOC and for appropriate reference sites, and effects will be estimated by comparing, for similar habitats, results between the AOCs and the reference sites.

\subsubsection{Toxicity Studies}

\subsubsection{Results of Toxicity Tests}

Toxicity data collected during Phase 1 and Phase 2 activities will be used to develop dose response relationships for contaminated media and ecological receptors. The results of the acute and chronic toxicity tests will be presented by media and by AOC. Detailed habitat maps will be generated through GIS analyses showing locations at each AOC where media were determined to be toxic to biota.

The results of the definitive toxicity tests will be presented, and graphical representations of the dose-response curves will be provided for each contaminant, by media, where such responses were obtained. 


\subsubsection{Toxicity Benchmark Values}

Derivation of benchmark values will largely follow the approach presented in ICF-Kaiser Engineers (1993a). In addition, maximum allowable tissue concentrations (MATCs) may be estimated for contaminants of concern that are highly fat soluble and have long persistence times. Derivation of MATCs will follow the methodology presented in Calabrese and Baldwin (1993). To the extent possible, the dose response relationships developed during the Phase 2 activities from definitive toxicity tests, as well as published toxicity data (e.g., Will and Suter 1994; Opresko et al. 1994), will be used to develop site-specific toxicity benchmark values for terrestrial wildlife.

Federal or state ambient water quality criteria (AWQCs) will be used as benchmark values for aquatic biota. For surface water contaminants for which there are no AWQCs, toxicity benchmark values will be developed following the approach used by the EPA (1986). Sediment benchmark values will be developed following the approach identified in ICF-Kaiser Engineers (1993a).

\subsection{STATISTICAL ANALYSES}

Statistical analyses of the data collected during the ERA will include calculation of summary statistics such as means, ranges, and standard deviations of the data sets from each AOC and from each reference site. Correlation and regression analyses will be performed to test for significant relationships between soil chemical and biotic parameters (such as diversity, biomass, or $\mathrm{N}$-mineralization) at particular sites. Statistical differences in the results of toxicity tests (e.g., percent survival or growth), diversity indices, biomass calculations, or other ecological and toxicological measurements for AOCs and the reference sites will be determined using standard statistical methods, such as correlation, t-tests, and analyses of variance. A univariate procedure will be performed upon data sets to determine whether the error variation is homogeneous and normally distributed. If necessary, the data set will be appropriately transformed, or a nonparametric statistical procedure will be used. The significance level for all statistical tests will be $\mathrm{p} \leq 0.05$.

\subsection{RISK EVALUATION}

In contrast to human health risk assessments, no standard approach currently exists for estimating ecological risks from chemical contamination. For the J-Field ERA, risk evaluation will be both qualitative and quantitative and will generally follow the draft interim guidelines for ecological risk assessment developed at EPA Region III (Davis 1994) and the approach presented in ICF-Kaiser Engineers (1993a). Specifically, ecological risk will be evaluated by using (1) EEQ values based on media concentrations, (2) EEQ values based on estimated $\mathrm{ADD}$ values, and (3) a weight-of-evidence approach that considers the results of the biosurveys, toxicity tests, and ADD estimates. 


\subsubsection{Risk Estimation}

The use of EEQ values is one of the most common approaches for estimating risks to ecological resources. The EEQ is simply the ratio of a predicted effect or exposure value for a specific contaminant to a benchmark effect or exposure value for that contaminant. The EEQ is calculated as

$$
\mathrm{EEQ}=(\text { Effects or exposure value }) \div(\text { benchmark value })
$$

Values of the EEQ may range from 0 to greater than 1. Values greater than 1 represent a potential risk, values greater than 10 represent a moderately high potential risk, and values greater than 100 represent extreme risk (Davis 1994). However, there are multiple contaminants of concern at each AOC, and the EEQ estimates risk only for single contaminants. Risk associated with exposure to multiple, co-occurring contaminants will be estimated by calculating a hazard index (HI). The HI is the sum of the individual EEQs for each contaminant at the AOC. Estimation of EEQ and $H I$ values will include considerations of uncertainty and high outliers as suggested by EPA Region III (Davis 1994).

For aquatic receptors, the EEQ and HII values will be estimated by using the observed media concentrations and the no-observed-adverse-effects-level (NOAEL) concentrations, such as the EPA chronic AWQC (EPA 1986). For terrestrial wildlife receptors, the EEQ and $\mathrm{HI}$ values will be estimated by using the estimated ADD and toxicity benchmark values or MATCs. All safety factors used in developing the NOAEL, toxicity benchmark, and MATC values will be identified.

In contrast to the rather simplistic EEQ approach for risk estimation, the weight-of-evidence approach represents the most scientifically rigorous assessment approach (Davis 1994) and evaluates all the data collected during the ERA. The results of the biotic surveys and toxicity tests will be used to identify the spatial extent and magnitude of observed or potential adverse ecological impacts, while ADD values will be used to estimate risks to higher trophic level receptors.

\subsubsection{Uncertainty}

Uncertainty associated with the risk assessment will be addressed both qualitatively and quantitatively. Sources of uncertainty that will be addressed in the risk evaluation will include (1) the conceptual model, (2) extrapolation across taxa during the development of benchmark values, (3) incomplete or insufficient data, (4) natural variability, and (5) analytical error. The uncertainty discussion will also present the results of the Monte Carlo uncertainty analysis, as well as the sensitivity analyses for the dose models.

\subsubsection{Ecological Significance}

The risk evaluation will include a discussion of the ecological significance of the observed or predicted risks. The evaluation of the ecological significance of the risk will be 
critical in understanding the implications to the remedial decisions that will ultimately be made for J-Field. Specifically, the interpretation of ecological significance will address the following questions:

- Which receptors are most at risk?

- Where are the greatest impacts (by AOC and media) likely to occur?

- What is the expected magnitude of the observed or predicted impact?

- How are the magnitude and likelihood of occurrence of the impact related?

- What does the impact mean ecologically?

Only when these questions are addressed can the results of the ERA be evaluated relative to the remedial decision-making process at J-Field. For example, an observed or predicted $5 \%$ reduction in plant biomass for a 0.5 -acre grassland habitat would probably not be considered ecologically significant, and it would probably not necessitate an extensive and expensive cleanup. In contrast, a $50 \%$ reduction in wetland vegetation biomass would be considered ecologically significant and would likely warrant extensive consideration during the design and evaluation of remedial alternatives.

\subsection{FINAL REPORT}

The results of all field and laboratory activities, dose modeling, uncertainty analyses, and risk evaluation will be presented in a final ERA report. That report will include the following information:

- The ecological contaminants of concern, as well as the rationale used in their selection;

- The ecological receptors and their exposure pathways;

- The field and laboratory methods used in performing the exposure and effects assessments;

- A summary of the chemical and biological data;

- The risk estimation approach and results;

- A discussion of the uncertainty associated with the overall assessment; and

- A determination of the ecological significance of the predicted risks. 


\section{REFERENCES}

ASTM - see American Society for Testing and Materials.

American Society for Testing and Materials, 1980, Standard Practice for Conducting Acute Toxicity Tests with Fish, Macroinvertebrates, and Amphibians, ASTM Standard E729-80, Philadelphia, Pa.

American Society for Testing and Materials, 1990a, Standard Guide for Assessing the Hazard of a Material to Aquatic Organisms and Their Uses, ASTM Standard E1023-90, Philadelphia, $\mathrm{Pa}$.

American Society for Testing and Materials, 1990b, Standard Guide for Conducting 10-Day Static Sediment Toxicity Tests with Marine and Estuarine Amphipods, ASTM Standard E1367-90, Philadelphia, Pa.

American Society for Testing and Materials, 1990c, Standard Guide for Conducting Sediment Toxicity Tests with Freshwater Invertebrates, ASTM Standard E1383-90, Philadelphia, Pa.

American Society for Testing and Materials, 1990d, Standard Guide for Collection, Storage, Characterization, and Manipulation of Sediments for Toxicological Testing, ASTM Standard E1391-90, Philadelphia, Pa.

Barbour, M.G., et al., 1987, Terrestrial Plant Ecology (2nd ed.), Benjamin/Cummings, Menlo Park, Calif.

Benioff, P., et al., 1995a, Remedial Investigation Work Plan for J-Field, Aberdeen Proving Ground, Maryland, ANL/EAD/TM-40, Argonne National Laboratory, Argonne, Ill., March.

Benioff, P., et al., 1995b, Remedial Investigation Sampling and Analysis Plan for J-Field, Aberdeen Proving Ground, Maryland, Volume 1: Field Sampling Plan, ANL/EAD/TM-38, Vol. 1, Argonne National Laboratory, Argonne, Ml., March.

Biang, C., et al., 1995, Work Plan for Focused Feasibility Study of the Toxic Burning Pits Area at J-Field, Aberdeen Proving Ground, Maryland, ANL/EAD/TM-39, Argonne National Laboratory, Argonne, Ill., March.

Bureau of Land Management, 1986, Inventory and Monitoring of Wildlife Habitat, A.Y. Cooperrider, R.J. Boyd, and H.R. Stuart (editors), U.S. Department of Interior, Bureau of Land Management, Service Center, Denver, Colorado.

Burton, G.A., Jr., 1991, "Assessing the Toxicity of Freshwater Sediments," Environmental Toxicology and Chemistry 10:1585-1627.

Calabrese, E.J., and L.A. Baldwin, 1993, Performing Ecological Risk Assessments, Lewis Publishers, Chelsea, Michigan, pp. 257. 
Callahan, C.A., et al., 1991, "On-Site Methods for Assessing Chemical Impact on the Soil Environment Using Earthworms: A Case Study at the Baird and McGuire Superfund Site, Holbrook, Massachusetts," Environmental Toxicology and Chemistry 10:817-926.

Carlson, C.L., et al., 1991, "Effects of Selected Trace Metals on Germinating Seeds of Six Plant Species," Water, Air, and Soil Pollution 59:231-240.

COE - see U.S. Army Corps of Engineers.

Costanza, R., 1987, "Simulation Modeling on the Macintosh Using STELLA ${ }^{\mathrm{TM}}$," BioScience 37:129-132.

Cowardin, L.M., et al., 1979, Classification of Wetlands and Deepwater Habitats of the United States, FWS/OBS-79/31, Fish and Wildlife Service, U.S. Department of the Interior, Dec.

Cowgill, U.M., et al., 1991, "The Sensitivity of Lemna Gibba G-3 and Four Clones of Lemna Minor to Eight Common Chemicals Using a 7-Day Test," Research Journal Water Pollution Control Federation 63:991-998.

Davis, R.S., 1994, Region III Interim Ecological Risk Assessment Guidelines, Technical Support Section, Superfund Program Branch, Hazardous Waste Management Division, U.S. Environmental Protection Agency, Region III, Philadelphia, Pa., July.

Decisioneering, Inc., 1993, Crystal Ball ${ }^{\mathrm{TM}}$, Version 3.0, Users Manual, Denver, Colo.

Devillers, J., and J.M. Exbrayat (editors), 1992, Ecotoxicity of Chemicals to Amphibians, Gordon and Breach Science Publishers, Philadelphia, Penn., pp. 351.

Environmental Laboratory, 1987, Corps of Engineers Wetlands Delineation Manual, Technical Report Y-87-1, U.S. Army Engineer Waterways Experiment Station, Vicksburg, Mississippi.

Fletcher, J.S., 1990, "Use of Algae Versus Vascular Plants to Test for Chemical Toxicity," in W. Wang, J.W. Gorsuch, and W.R. Lower (eds.), Plants for Toxicity Assessment, ASTM STP 1091, American Society for Testing and Materials, Philadelphia, Pa., pp. 33-39.

Gorsuch, J.W., et al., 1991, Plants for Toxicity Assessment (2nd Vol.), American Society for Testing and Materials, Philadelphia, $\mathrm{Pa}$.

Hughes, W.B., 1992, letter with attachment from Hughes (U.S. Geological Survey, Towson, Md.) to J. Wrobel (U.S. Army, Aberdeen Proving Ground, Md.), June 19.

Hughes, W.B., 1993, Hydrogeology and Soil-Gas at J-Field, Aberdeen Proving Ground, Maryland, U.S. Geological Survey Water-Resources Investigations Report 92-4087, prepared in cooperation with the U.S. Army, Aberdeen Proving Ground Support Activity, Environmental Management Division, Towson, Md. 
Hunsaker, C.T., et al., 1989, Regional Ecological Risk Assessment: Theory and Demonstration, ORNL/TM-11128, Oak Ridge National Laboratory, Oak Ridge, Tenn.

ICF-Kaiser Engineers, 1992, Workplan for Conducting Human Health and Ecological Risk Assessments at the O-Field Study Area, Abingdon, Md.

ICF-Kaiser Engineers, 1993a, Risk and Biological Impact Assessment at U.S. Army Aberdeen Proving Ground, Maryland, Technical Plan Volume I, Abingdon, Md.

ICF-Kaiser Engineers, 1993b, Risk and Biological Impact Assessment at U.S. Army Aberdeen Proving Ground, Maryland Technical Plan, Volume II, Abingdon, Md.

Ingersoll, C.G., 1991, "Sediment Toxicity and Bioaccumulation Testing," Standard News 19(4):28-33.

Karnak, R.E., and J.L. Hamelink, 1982, "A Standardized Method for Determining the Acute Toxicity of Chemicals to Earthworms," Ecotoxicology and Environmental Safety 6:216-222.

Leibowitz, N.C., and L. Squires, 1991, Environmental Monitoring and Assessment Program Research Plan for Monitoring Wetland Ecosystems, EPA/600/5-91/010, U.S. Environmental Protection Agency, Environmental Research Laboratory, Corvallis, Ore., Feb.

Mazelon, M., 1993, Letter from Mazelon (Chief Engineer, Roy F. Weston, Inc., Aberdeen Proving Ground, Md.) to R. Rizzieri (U.S. Army Corps of Engineers, Aberdeen Proving Ground, Md.), Feb. 26.

Menzie, C.A., et al., 1992, "Assessment of Methods for Estimating Ecological Risk in the Terrestrial Component: A Case Study at the Baird and McGuire Superfund Site in Holbrook, Massachusetts," Environmental Toxicology and Chemistry 11:245-260.

Mueller-Dombois, D., and H. Ellenberg, 1974, Aims and Methods of Vegetation Ecology, Wiley, New York, N.Y.

Nemeth, G., 1989, RCRA Facility Assessment, Edgewood Area, Aberdeen Proving Ground, $M D, 39-26-0490-90$, U.S. Army Environmental Hygiene Agency, Waste Disposal Engineering Division, Aberdeen Proving Ground, Md., Nov.

Opresko, D.M., et al., 1994, Toxicological Benchmarks for Wildlife, 1994 Revision, ES/ER/TM-86/R1, prepared by Environmental Sciences Division, Oak Ridge National Laboratory, Oak Ridge, Tenn., for U.S. Department of Energy, Office of Environmental Restoration and Waste Management, Sept.

Orvos, D.R., and J. Cairns, Jr., 1991, "Developing a Risk Assessment Strategy for the Chesapeake Bay," Hydrobiologia 215:189-203.

Outridge, P.M., and B.N. Noller, 1991, "Accumulation of Toxic Trace Elements by Freshwater Vascular Plants," Reviews of Environmental Contamination and Toxicology 121:1-63. 
Prasad, S., et al., 1995, Remedial Investigation Sampling and Analysis Plan for J-Field, Aberdeen Proving Ground, Maryland, Volume 2: Quality Assurance Project Plan, ANL/EAD/TM-38, Vol. 2, Argonne National Laboratory, Argonne, Ill., March.

Princeton Aqua Science, 1984, Munitions Disposal Study, prepared for Directorate of Engineering and Housing, Environmental Management Office, Department of the Army, Aberdeen Proving Ground, Md., Nov.

Schlekat, C.E., et al., 1992, "Testing Sediment Toxicity in Chesapeake Bay with the Amphipod Leptocheirus plumulosus: An Evaluation," Environmental Toxicology and Chemistry 11:225-236.

Shatkin, J.A., and H.S. Brown, 1991, "Pharmacokinetics of the Dermal Route of Exposure to Volatile Organic Chemicals in Water: A Computer Simulation Model," Environmental Research 56:90-108.

Sonntag, W., 1991, Sampling and Analysis Plan for the Investigation of Ground Water Contamination at J-Field, Aberdeen Proving Ground, Maryland, U.S. Geological Survey, Reston, Va.

Stevens, D.L., Jr., 1988, "Field Sampling Design," in W. Warren-Hicks (ed.), Ecological Assessments of Hazardous Waste Sites: A Field and Laboratory Reference Document, EPA/600/3-89/013, U.S. Environmental Protection Agency, Corvallis, Ore., pp. 4-1 - 4-13.

U.S. Army, 1965, aerial photograph of Edgewood Area, roll no. G\&O 85047, frame nos. 8-1 to 8-2 and 9-1 to 9-4, Environmental Hygiene Agency, Aberdeen Proving Ground, Md.

U.S. Army Corps of Engineers, 1993, Work Plan for CERCLA Remedial Investigation/Feasibility Study; Appendix J, Standard Operating Procedures, Directorate of Safety, Health, and Environment, U.S. Army Aberdeen Proving Ground, Md., in cooperation with Waterways Experiment Station, Vicksburg, Miss., Dec.

U.S. Army Toxic and Hazardous Materials Agency, 1991, Draft Baseline Risk Assessment for Eight Selected Study Areas at Aberdeen Proving Ground, Aberdeen Proving Ground, Md.

U.S. Environmental Protection Agency, 1986, Quality Criteria for Water 1986, EPA 440/5-86-001, Office of Water Regulations and Standards, Washington, D.C., May.

U.S. Environmental Protection Agency, 1989a, Risk Assessment Guidance for Superfund, Environmental Evaluation Manual, Interim Final, EPA/540/1-89/001, Office of Emergency and Remedial Response, Washington, D.C.

U.S. Environmental Protection Agency, 1989b, Ecological Risk Assessment Methods: A Review and Evaluation of Past Practices in the Superfund and RCRA (Resource Conservation and Recovery Act) Programs, EPA-230-03-89-044, Office of Policy Analysis, Washington, D.C. 
U.S. Environmental Protection Agency, 1989c, Summary of Ecological Risks, Assessment Methods, and Risk Management Decisions in Superfund and RCRA, EPA-230-03-89-046, Office of Policy Analysis, Washington, D.C.

U.S. Environmental Protection Agency, 1991, Summary Report on Issues in Ecological Risk Assessment, EPA/625/3-91/018, Office of Health and Environmental Assessment, Washington, D.C.

U.S. Environmental Protection Agency, 1992a, ECO Update: Developing a Work Scope for Ecological Assessments, EPA 9345.0-051, Washington, D.C., May.

U.S. Environmental Protection Agency, 1992b, Framework for Ecological Risk Assessment, EPA/630/R-92/001, Washington, D.C., February.

U.S. Environmental Protection Agency, 1993, Wildlife Exposure Factors Handbook, vols. I and II, EPA/600/R-93/187a and b, Office of Research and Development, Washington, D.C., Dec.

USGS - see U.S. Geological Survey.

U.S. Geological Survey, 1990, Sampling and Analysis Plan for the Investigation of GroundWater Contamination at J-Field, Aberdeen Proving Ground, Md., Towson, Md.

U.S. Geological Survey, 1991, Phase II Workplan and Field Sampling Plan Update for the Remedial Investigation at J-Field Aberdeen Proving Ground, Maryland, prepared by Water Resources Division, Towson, Md., for the U. S. Army, Aberdeen Proving Ground Support Activity, Environmental Management Division, May.

U.S. Geological Survey, 1992, unpublished data.

Wang, W., 1986a, "Comparative Toxicology of Phenolic Compounds Using Root Elongation Method," Environmental Toxicology and Chemistry 5:891-896.

Wang, W., 1986b, "Toxicity Tests of Aquatic Pollutants by Using Common Duckweed," Environmental Pollution (Series B) 11:1-14.

Wang, W., et al., 1990, Plants for Toxicity Assessment, American Society of Testing and Materials, Philadelphia, $\mathrm{Pa}$.

Warren-Hicks, W., et al. (editors), 1989, Ecological Assessment of Hazardous Waste Sites: A Field and Laboratory Reference, EPA/600/3-89/013, U.S. Environmental Protection Agency, Environmental Research Laboratory, Corvallis, Ore., March.

Weston, Roy F., 1992, Characterization and Interim Remediation of J-Field at Edgewood Area Aberdeen Proving Ground, Maryland, Roy F. Weston, Inc., for U.S. Army Corps of Engineers, Baltimore District. 
Will, M.E., and G.W. Suter, 1994, Toxicological Benchmarks for Screening Potential Contaminants of Concern for Effects on Terrestrial Plants: 1994 Revision, ES/ER/TM-85/R1, prepared by Environmental Sciences Division, Oak Ridge National Laboratory, Oak Ridge, Tenn., for U.S. Department of Energy, Office of Environmental Restoration and Waste Management, Sept.

Yeardley, R.B., et al., 1993, "A New Earthworm Avoidance Test and Its Potential Applications," presented at Society of Environmental Toxicology and Chemistry Annual Meeting, Houston, Texas, Nov. 14-18. 


\section{LIST OF PREPARERS}

This ERA work plan was prepared for the U.S. Army Directorate of Safety, Health, and Environment by the Environmental Assessment Division of ANL. The following ANL staff have contributed to the preparation of this work plan.

\begin{tabular}{|c|c|c|}
\hline Name & Education/Experience & Contribution \\
\hline Louis Martino & $\begin{array}{l}\text { M.S., environmental toxicology; } \\
15 \text { years experience in environmental } \\
\text { assessment; J-Field project manager. }\end{array}$ & $\begin{array}{l}\text { Section } 2 \text { Environmental } \\
\text { Conditions at J-Field }\end{array}$ \\
\hline Thor Hlohowskyj & $\begin{array}{l}\text { Ph.D., zoology; } 19 \text { years experience in } \\
\text { ecological research; } 16 \text { years } \\
\text { experience in environmental } \\
\text { assessment; ERA project manager } \\
\text { and lead author. }\end{array}$ & $\begin{array}{l}\text { Section } 1 \text { Introduction } \\
\text { Section } 3 \text { Contaminants of } \\
\text { Concern, Exposure Pathways, } \\
\text { and Principal Receptors } \\
\text { Section } 4 \text { Objectives and Scope } \\
\text { of the Risk Assessment } \\
\text { Section } 5 \text { Sampling and Analysis } \\
\text { Section } 7 \text { Data Presentation, } \\
\text { Analysis, and Interpretation }\end{array}$ \\
\hline Paul Benioff & $\begin{array}{l}\text { Ph.D., nuclear chemistry; } 17 \text { years } \\
\text { experience in theoretical chemistry; } \\
16 \text { years experience in environmental } \\
\text { assessment. }\end{array}$ & $\begin{array}{l}\text { Section } 2 \text { Environmental } \\
\text { Conditions at J-Field }\end{array}$ \\
\hline Randall Biang & $\begin{array}{l}\text { M.S., geology; } 11 \text { years experience in } \\
\text { groundwater and hazardous waste } \\
\text { investigations. }\end{array}$ & $\begin{array}{l}\text { Section } 2 \text { Environmental } \\
\text { Conditions at J-Field }\end{array}$ \\
\hline $\begin{array}{l}\text { Christopher } \\
\text { Dunn }\end{array}$ & $\begin{array}{l}\text { Ph.D., plant ecology; } 13 \text { years } \\
\text { experience in ecological research and } \\
\text { environmental assessment. }\end{array}$ & $\begin{array}{l}\text { Section } 2 \text { Environmental } \\
\text { Conditions at J-Field } \\
\text { Section } 5 \text { Sampling and Analysis }\end{array}$ \\
\hline John Hayse & $\begin{array}{l}\text { Ph.D., zoology; } 12 \text { years experience in } \\
\text { aquatic ecology; } 4 \text { years experience in } \\
\text { environmental assessment. }\end{array}$ & $\begin{array}{l}\text { Section } 3 \text { Contaminants of } \\
\text { Concern, Exposure Pathways, } \\
\text { and Principal Receptors } \\
\text { Section } 5 \text { Sampling and Analysis } \\
\text { Section } 6 \text { Records Management } \\
\text { Appendix B Sampling of } \\
\text { Sediments from Bomb Craters } \\
\text { at J-Field }\end{array}$ \\
\hline $\begin{array}{l}\text { Roman } \\
\text { Kuperman }\end{array}$ & $\begin{array}{l}\text { Ph.D., entomology; } 15 \text { years } \\
\text { experience in ecological research; } \\
12 \text { years experience in environmental } \\
\text { assessment. }\end{array}$ & $\begin{array}{l}\text { Section } 5 \text { Sampling and Analysis } \\
\text { Appendix A Methods for } \\
\text { Evaluating Biological Processes } \\
\text { in Soils at J-Field }\end{array}$ \\
\hline
\end{tabular}




\begin{tabular}{|c|c|c|}
\hline Name & Education/Experience & Contribution \\
\hline Terri Patton & $\begin{array}{l}\text { M.S., geology; } 6 \text { years experience in } \\
\text { radiochemical analysis; } 5 \text { years } \\
\text { experience in environmental } \\
\text { assessment. }\end{array}$ & $\begin{array}{l}\text { Section } 2 \text { Environmental } \\
\text { Conditions at J-Field } \\
\text { Section } 6 \text { Records Management }\end{array}$ \\
\hline Elisabeth Stull & $\begin{array}{l}\text { Ph.D., zoology; } 30 \text { years experience in } \\
\text { ecological research; } 20 \text { years } \\
\text { experience in environmental } \\
\text { assessment. }\end{array}$ & $\begin{array}{l}\text { Section } 4 \text { Objectives and Scope of } \\
\text { the Risk Assessment } \\
\text { Section } 5 \text { Sampling and Analysis }\end{array}$ \\
\hline $\begin{array}{l}\text { Robert Van } \\
\text { Lonkhuyzen }\end{array}$ & $\begin{array}{l}\text { B.A., biology; } 5 \text { years experience in } \\
\text { ecological and environmental } \\
\text { research, wetlands delineation, and } \\
\text { assessment. }\end{array}$ & Section 5 Sampling and Analysis \\
\hline Cheong-Yip Yuen & $\begin{array}{l}\text { Ph.D., geology (hydrogeology and } \\
\text { environmental geology); } 6 \text { years } \\
\text { experience in hydrogeological } \\
\text { analysis; } 12 \text { years experience in } \\
\text { process geomorphology. }\end{array}$ & $\begin{array}{l}\text { Section } 2 \text { Environmental } \\
\text { Conditions at J-Field } \\
\text { Appendix B Sampling of } \\
\text { Sediments from Bomb Craters } \\
\text { at J-Field }\end{array}$ \\
\hline
\end{tabular}




\section{APPENDIX A:}

\section{METHODS FOR EVALUATING BIOLOGICAL PROCESSES \\ IN SOILS AT J-FIELD}

\section{A.1 INTRODUCTION}

Much of the contamination present at J-Field is associated with the soil. Soil processes and biota are important components of the ecosystem at J-Field; specifically, biological soil processes (such as nitrogen [N] mineralization and decomposition) are critical in the cycling of nutrients and thus the primary productivity of terrestrial ecosystems. This appendix presents the methods that will be used during the ERA at J-Field to assess realized and potential effects of site contamination on important biological soil processes.

\section{A.2 SOIL NITROGEN MINERALIZATION ASSAYS}

\section{A.2.1 Rationale and Approach}

Nitrogen utilization requires distinct enzymatic steps for extracellular hydrolysis, uptake, deamination, and intracellular catabolism, each of which could be affected differently by pollutants. The effects of soil contamination on the overall nitrogen mineralization provides important information regarding changes in the availability of this critical nutrient in the ecosystem.

\section{A.2.2 Field Procedures}

Net nitrogen mineralization is quantified by the polyvinyl chloride (PVC) incubation tube method. At each soil sampling location, ten PVC incubation tubes (5-cm diameter $\times$ $20-\mathrm{cm}$ length) are inserted into the ground to a depth of $15 \mathrm{~cm}$; the upper $5 \mathrm{~cm}$ of the tube remains aboveground and is sealed. Start-of-incubation bulk soil samples are concurrently collected from the same sampling locations to determine initial concentrations of potassium chloride (KCl)-extractable inorganic $\mathrm{N}$ (ammonium-nitrogen $\left[\mathrm{NH}_{4}-\mathrm{N}\right]$ and nitrate-nitrogen $\left[\mathrm{NO}_{3} / \mathrm{NO}_{2}-\mathrm{N}\right]$ ). At the end of the field incubation period (4 to 6 weeks), all tubes are removed from the soil, and the soils within the tubes are transferred into polypropylene bags ( $1 \mathrm{per}$ PVC tube) and transported in a cooler to the laboratory for analysis. The soils are then prepared and analyzed (as described below) for KCl-extractable inorganic $\mathrm{N}\left(\mathrm{NH}_{4}-\mathrm{N}\right.$ and $\left.\mathrm{NO}_{3} / \mathrm{NO}_{2}-\mathrm{N}\right)$. Net $\mathrm{N}$ mineralization is calculated as the sum of $\mathrm{NH}_{4}-\mathrm{N}$ and $\mathrm{NO}_{3} / \mathrm{NO}_{2}-\mathrm{N}$ in the closed core after incubation, minus the amount present before incubation. 


\section{A.2.3 Laboratory Procedures}

In the laboratory, each soil core is broken apart by hand, mixed, and then passed through a No. 10 sieve (2-mm diameter) to remove coarse organic matter, rocks, and other materials. Approximately 10- to 12-g portions of the soil are weighed into labeled, tared $125-\mathrm{mL}$ flasks, and $50 \mathrm{~mL}$ of $2 \mathrm{M} \mathrm{KCl}$ is added. The flasks are covered and shaken vigorously for 1 hour to break up soil aggregates. The resultant soil sample and solution is allowed to settle for 15-20 minutes, after which the supernatant is decanted and filtered through Whatman 42 filter paper into labeled polyethylene sample vials.

A second portion (about 150-250 g) of each soil sample is weighed into a tared, labeled paper bag and dried at $60^{\circ} \mathrm{C}$ to a constant weight. This sample is used to determine the moisture content of the soil and to generate a wet-to-dry weight conversion factor for that sample. Dried samples are saved in labeled storage containers for total $\mathrm{N}$ and other future analyses.

The filtered soil extracts are refrigerated at $2-4^{\circ} \mathrm{C}$ until analysis. Extracts are analyzed for $\mathrm{NH}_{4}-\mathrm{N}$ and $\mathrm{NO}_{3} / \mathrm{NO}_{2}-\mathrm{N}$ concentrations using the Lachat QuikChem $\mathrm{AE}$ autoanalyzer. $\mathrm{NH}_{4}-\mathrm{N}$ analysis should be done within 2 weeks, and $\mathrm{NO}_{3} / \mathrm{NO}_{2}-\mathrm{N}$ analysis should be done within 4 weeks.

Extractable $\mathrm{NH}_{4}-\mathrm{N}$ and $\mathrm{NO}_{3} / \mathrm{NO}_{2}-\mathrm{N}$ concentrations are expressed as gram $\mathrm{N}$ per gram dry weight of soil. This is estimated as ppm $\mathrm{NH}_{4}-\mathrm{N}$ or $\mathrm{NO}_{3} / \mathrm{NO}_{2}-\mathrm{N}$ in the extract $\times 50 \mathrm{~mL}$ of extract per dry weight of extracted soil.

\section{A.2.4 Quality Assurance/Quality Control Procedures}

Quality assurance/quality control procedures for soil extractable $\mathrm{NH}_{4}-\mathrm{N}$ and $\mathrm{NO}_{3} / \mathrm{NO}_{2}-\mathrm{N}$ consist of reagent blanks, duplicate samples, split samples, a standard soil, and check standards. For each block of samples (usually the samples for a given collection date), a "standard" air-dried soil will be extracted, a randomly chosen soil sample will be extracted and analyzed in duplicate, and a reagent blank (empty flask) will be run. Every twentieth sample cup on the Lachat autoanalyzer will contain a check standard, which must meet the criteria specified in the QA/QC plan for J-Field.

\section{A.3 SOIL MICROBIAL BIOMASS NITROGEN}

\section{A.3.1 Rationale and Approach}

Soil microorganisms play a critical role in nutrient cycling in terrestrial ecosystems and serve as sources and receptors of plant nutrients. Thus, a reduction in soil microbial biomass due to soil contamination may serve as a measure of potential impacts to nutrient cycling and the availability of nutrients to plants. In this approach, chloroform fumigation 
(Brookes et al. 1985) is used to estimate microbial biomass of soils exhibiting varying degrees of chemical contamination.

\section{A.3.2 Field Procedures}

Soil samples are collected with a 5-cm diameter stainless steel soil corer marked at a depth of $10 \mathrm{~cm}$. Immediately upon collection, the soil samples are placed into a cooler and stored at $2-4^{\circ} \mathrm{C}$ until processing and analysis.

\section{A.3.3 Laboratory Procedures}

\section{A.3.3.1 Extraction and Fumigation/Extraction}

The soil core sample is broken apart by hand, mixed, and passed through a No. 10 (2-mm diameter) soil sieve to remove coarse organic matter, large rocks, and other materials. A 10- to 12-g portion of soil is weighed into a labeled, tared 125-mL flask, and $50 \mathrm{~mL}$ of $0.5 \mathrm{M}$ potassium sulfate is added to the flask, which is then covered and shaken vigorously for 1 hour to break up soil aggregates. The resulting soil solution is allowed to settle for 15-20 minutes and then the supernatant is decanted and filtered through a Whatman 42 filter paper into a labeled polyethylene sample vial.

A second 10- to 12-g soil sample from the same soil core sample is weighed into a second labeled, tared $125-\mathrm{mL}$ flask. The flask is placed into a vacuum desiccator with moist paper towels on the bottom. A $50-\mathrm{mL}$ beaker with approximately $30 \mathrm{~mL}$ of purified chloroform (Section A.3.3.2) and a few glass or teflon boiling beads is also placed in the desiccator. The desiccator is aspirated until the chloroform boils. The vacuum is then maintained in the desiccator for 1 to 2 hours. After this period, the desiccator is again aspirated and the chloroform is brought to a boil a second time. The chloroform is brought to a boil a third time after about 24 hours, and this last fumigation period is maintained for 5 days.

Following completion of the 5-day fumigation period, the vacuum is released, the desiccator is opened, and the beaker with chloroform is removed. A vacuum is repeatedly applied, opening the desiccator between applications to remove traces of chloroform from the soil. The soils then undergo the potassium sulfate treatment procedure described above.

A third portion (approximately $100 \mathrm{~g}$ ) of the soil core sample is weighed into a tared, labeled paper bag and dried at $60^{\circ} \mathrm{C}$ to a constant weight. This sample is used to determine the moisture content of the soil and to generate a wet-to-dry weight conversion factor.

Extracts must be digested (Section A.3.3.3) to determine total extractable $\mathrm{N}$ before and after fumigation. Filtered soil extracts are refrigerated at $2-4^{\circ} \mathrm{C}$ until they are digested. Extracts should be digested within 4 weeks. Digested samples are stable and may be analyzed when convenient. 
Total extractable $\mathrm{N}$ concentration before and after fumigation is expressed as gram $\mathrm{N}$ per gram dry weight of soil (ppm). Microbial biomass $\mathrm{N}$ is calculated as

([ppm $\mathrm{N}$ after fumigation] - [ppm $\mathrm{N}$ before fumigation])/0.68 .

Dissolved organic $\mathrm{N}$ is calculated as ppm total $\mathrm{N}$ in nonfumigated soils less ppm extractable inorganic $\mathrm{N}\left(\mathrm{NH}_{4}-\mathrm{N}\right.$ and $\left.\mathrm{NO}_{3} / \mathrm{NO}_{2}-\mathrm{N}\right)$ from the extractable $\mathrm{N}$ analysis.

\section{A.3.3.2 Chloroform Purification}

To prepare the chloroform needed to fumigate the soil samples, $300 \mathrm{~mL}$ of analytical-grade chloroform is poured into a $500-\mathrm{mL}$ separatory funnel, $75 \mathrm{~mL}$ of concentrated sulfuric acid is added, and the mixture is shaken for 1 minute. The mixture is then allowed to settle for 5 minutes, after which the sulfuric acid is drained off. This procedure is then repeated.

After the second treatment with sulfuric acid, $100 \mathrm{~mL}$ of deionized water is added to the chloroform. The mixture is shaken for 1 minute, allowed to settle for 5 minutes, and then the chloroform is drained into a round flask for attachment to a rotary evaporator. The chloroform mixture is distilled under vacuum using the rotary evaporator and a $60^{\circ} \mathrm{C}$ water bath. Each batch of chloroform is passed twice through this distillation process. The purified chloroform is stored and refrigerated in a dark bottle, and it must be used within one week.

\section{A.3.3.3 Persulfate Digestion of Soil Extracts}

Persulfate oxidizing reagent is prepared by adding $3.12 \mathrm{~g}$ of boric acid, $5.2 \mathrm{~g}$ low-N potassium persulfate, $10 \mathrm{~mL} 3.75 \mathrm{~N}$ sodium hydroxide, and about $80 \mathrm{~mL}$ deionized water to a 100-mL volumetric flask. Two $\mathrm{mL}$ of the soil extract (Section A.3.3.1) is pipetted into a 16- $\times 125-\mathrm{mm}$ screw-cap culture tube, $0.8 \mathrm{~mL}$ of a persulfate oxidizing reagent is added, and the tube is immediately capped. The tube is placed in an autoclave and set on the liquid cycle for 30 minutes. After the tubes have cooled, $2 \mathrm{~mL}$ of deionized water is added to each tube. autoanalyzer.

Digested extracts are analyzed for $\mathrm{NO}_{3}-\mathrm{N}$ concentrations using the Lachat

\section{A.3.4 Quality Assurance/Quality Control Procedures}

Quality assurance/quality control procedures for soil extractable $\mathrm{NH}_{4}-\mathrm{N}$ and $\mathrm{NO}_{3} / \mathrm{NO}_{2}-\mathrm{N}$ consist of reagent blanks, duplicate samples, split samples, a standard soil, and check standards. For each block of samples (usually the samples for a given collection date), a standard air-dried soil will be extracted, a randomly chosen soil sample will be extracted and analyzed in duplicate, and a reagent blank (empty flask) will be run. 


\section{A.4 LITTER DECOMPOSITION AND MINERALIZATION RATES}

\section{A.4.1 Rationale and Approach}

Decay rates and nutrient mineralization rates of plant residues will be determined using a litterbag method. In this approach, preweighed plant residues are confined in mesh litterbags and placed in the field. Subsets of litterbags are periodically harvested to determine mass loss and change in nutrient content.

\section{A.4.2 Litterbag Preparation}

Litterbags $(10 \times 10 \mathrm{~cm})$ are constructed of fiberglass mesh (1.5-mm opening). Plant material for use in the litterbags is collected at the time of plant senescence. Collected plant material is air-dried for 48 hours at room temperature. Each litterbag is filled with $4-5 \mathrm{~g}$ of the air-dried plant material and sealed. Subsamples of air-dried litter are oven-dried to develop air-dry to oven-dry conversion factors, and the subsamples are archived for later analysis of initial litter quality and nutrient composition.

\section{A.4.3 Field Procedures}

In wooded areas of J-Field, litterbags will be placed on the surface of the soil. In grassland areas, litterbags are buried in soil. Extra litterbags are taken to the field, handled as other litterbags, and then immediately returned to the laboratory to determine any loss of dried plant material due to handling.

Some litterbags from each AOC will be collected five to six months following placement in the field. Litterbags are placed into labeled polyethylene bags as they are collected. Litterbags will be stored in a cooler, returned to the laboratory, and stored at $4^{\circ} \mathrm{C}$ until processing. Litterbags are processed within 48 hours of collection if microarthropods are to be extracted, or within 1 week if mass loss and nutrients are to be analyzed.

\section{A.4.4 Laboratory Procedures}

The litterbags are opened upon return to the laboratory, and the contents are hand-sorted to remove as much soil as possible. The remaining plant materials are transferred into a paper envelope and dried at $60^{\circ} \mathrm{C}$. The plant residue and any associated soil materials are ground in a Wiley mill to pass through a 40 mesh screen. A 250-mg subsample is ashed in a muffle furnace at $500^{\circ} \mathrm{C}$ for 5 hours to determine the percent of ash-free dry mass (AFDM). A second 250-mg subsample is analyzed for total nitrogen and carbon content, using the Carlo/Erba NA1500 automated carbon/nitrogen analyzer. 
Because of contamination of plant residues with soil, residue masses must be corrected for soil infiltration using the following soil correction equation:

$$
F L i=(S a A F D M-S L A F D M) /(L i A F D M-S L A F D M) \text {, }
$$

where $F L i$ is the fraction of litterbag content that is actually litter; SaAFDM is the percent of AFDM of the entire litterbag sample; SLAFDM is the mean percent of AFDM of the soil from the field site; and LiAFDM is the percent of AFDM of the initial crop residue.

Daily decay rate constants of residues can be calculated using the single negative exponential decay model

$$
m_{t} / m_{0}=e^{-k t}
$$

where

$$
\begin{aligned}
m_{t} / m_{0} & =\text { proportion of mass remaining at time } t, \\
t & =\text { time elapsed in days, and } \\
k & =\text { the derived daily decay constant. }
\end{aligned}
$$

Patterns of net nutrient accumulation or release can be calculated as the product of the percent of mass remaining and nutrient concentration in the residual material at time $t$, divided by the initial nutrient concentration.

\section{A.5 SUBSTRATE-INDUCED RESPIRATION}

\section{A.5.1 Rationale and Approach}

The substrate-induced respiration method is used to estimate microbial activity in soil. The addition of substrate (glucose) to a soil sample induces a maximal respiratory response from the soil microbial biomass, measured as carbon dioxide evolution. Microbial biomass is the main acting agent for most soil biogeochemical processes in terrestrial ecosystems, and it interacts with the primary productivity of ecosystems by regulating nutrient availability and degradation pathways of soil contaminants.

Substrate-induced respiration is measured using a soil respiration measuring system with continuous gas flow (Cheng and Ross 1993; Cheng and Coleman 1989). The soil respiration measuring system involves an incubation chamber, an airflow controlling unit, an airflow measuring unit, and a carbon dioxide analyzer (LI-6251). 


\section{A.5.2 Sample Collection and Laboratory Procedures}

Soil cores are collected to a depth of $10 \mathrm{~cm}$ using a 5-cm diameter stainless steel corer, placed in polyethylene bags, and returned to the laboratory where they are broken apart by hand and mixed. Coarse organic matter, metal fragments, and large rocks are removed, and the soil is forced through a No. 10 sieve.

A 15-g subsample of the sieved soil is placed into a 125-mL Erlenmeyer flask, and glucose solution $(60 \mathrm{~g} / \mathrm{L})$ is added using a syringe to the flask to bring the soil water content near to its holding capacity (no free-standing solution).

The soil sample is then incubated until the rate of carbon dioxide evolution from the soil sample becomes constant at an airflow rate of $180 \mathrm{~mL} / \mathrm{min}$ (approximately $40 \mathrm{~min}$ ). The carbon dioxide evolution rate is then recorded as the substrate-induced respiration of that soil sample.

\section{A.5.3 Quality Assurance/Quality Control Procedures}

Quality assurance/quality control procedures for soil substrate-induced respiration consist of duplicate samples, split samples, a standard soil, and check standards. For each block of samples (usually the samples for a given collection date), a "standard" soil will be analyzed, a randomly chosen soil sample will be analyzed in duplicate, and a reagent blank (empty flask) will be run.

\section{A.6 SOIL ENZYME ACTIVITY}

\section{A.6.1 Rationale and Approach}

Soil enzyme activities are measured in AOCs to determine if the soil concentration of chemicals may have detrimental effects on the microbial activity, rates of organic matter degradation, and subsequent release of nutrients to aboveground communities in the area. This method quantifies the activity of beta-glucosidase, carboxymethylcellulase (carbon-acquiring enzymes), $\mathrm{N}$-acetylglucosaminidase (nitrogen-acquiring enzyme), and both acid and alkaline phosphatases (phosphorus-acquiring enzymes) in soil samples.

\section{A.6.2 Sample Collection and Laboratory Procedures}

Soil cores are collected with a 5-cm diameter stainless steel soil corer marked at a depth of $10 \mathrm{~cm}$. Soil samples are placed in a cooler as they are collected and stored at $2-4^{\circ} \mathrm{C}$ until transport to the laboratory. In the laboratory, the soil cores are held at $-20^{\circ} \mathrm{C}$ until analysis, which should be completed within three months of sample collection. 
The soil samples are thawed at room temperature for 2 hours and stored in the refrigerator at $4^{\circ} \mathrm{C}$ during subsequent handling. Samples must be processed and assayed within a two-day period. No samples can be held in the refrigerator for longer than 10 hours before being assayed.

When thawed, the soil core is broken apart, mixed, and assayed for beta-1,4,-glucosidase, cellulase, $\mathrm{N}$-acetylglucosaminidase, and acid and alkaline phosphatase. The assays are conducted at $25^{\circ} \mathrm{C}$ on soil slurries suspended in $\mathrm{pH} 5$ acetate buffer, except for samples assayed for alkaline phosphatase activity. These slurries are suspended in acetate buffer at $\mathrm{pH} 9.5$.

All the enzymes (except cellulase) are assayed colorimetrically using p-nitrophenol-linked substrates. These substrates are p-nitrophenol-beta-D-glucopyranoside, p-nitrophenol-n-acetylglucosaminide, and p-nitrophenol-phosphate. The cellulase assay is a viscometric assay that uses carboxymethyl cellulose as a substrate.

\section{A.6.3 Quality Assurance/Quality Control Procedures}

Quality assurance/quality control procedures for soil enzyme activity analyses consist of split samples and check standards.

\section{A.7 INSECT EGG DEVELOPMENT TEST}

\section{A.7.1 Rationale and Approach}

This test was designed to determine the toxicity of solid media to the development of insect eggs. A species of ground beetle Harpalus pensylvanicus is used as a test organism in this procedure.

\section{A.7.2 Field Collection of Beetles}

Adults (both females and males) of Harpalus pensylvanicus are collected with pitfall traps in undisturbed grasslands in late August and September, during the period of their high reproductive activity.

\section{A.7.3 Egg Collection}

In the laboratory, 20-30 beetles are placed in plastic containers $(19 \mathrm{~cm} \times 26 \mathrm{~cm} \times 10 \mathrm{~cm})$ with wet sand on the bottom $(2-3 \mathrm{~cm})$ and maintained at room temperature and ambient light conditions. A seed mixture (commercial bird feed) is provided as food to maintain a high rate of reproduction. Eggs are harvested daily by temporarily flooding the bottom of plastic containers with water and removing eggs from the sand surface. 


\section{A.7.4 Toxicity Testing}

Individual eggs are placed in the sample vials with moist test soil or uncontaminated control soil and incubated for $10-15$ days at $22^{\circ} \mathrm{C}$. Vials are inspected daily and deionized water is periodically added to keep the soil moist. The successful emergence of the first instar terminates this test and soil is qualified as nontoxic for egg development. To estimate soil toxicity, hatching success is compared among contaminated and uncontaminated soils. Vials with no larvae after 15 days of incubation are emptied in the petri dish and their contents are inspected. Eggs are dissected under the microscope, and the condition of the embryo is described. The normal 10- to 15-day-old embryos have developed segmentation, appendages, and a head capsule with a pair of pigmented eyes. If development of embryos was arrested (apparent discoloration and morphological deformation), soil is qualified as toxic for egg development.

\section{A.8 REFERENCES}

Brookes, P.C., et al., 1985, "Chloroform Fumigation and the Release of Soil Nitrogen: A Rapid Direct Extraction Method to Measure Microbial Biomass Nitrogen in Soil," Soil Biology and Biochemistry 17:837-842.

Cheng, W., and D.C. Coleman, 1989, "A Simple Method for Measuring $\mathrm{CO}_{2}$ in a Continuous Airflow System: Modifications to the Substrate-Induced Respiration Technique," Soil Biology and Biochemistry 21:385-388.

Cheng, W., and V.A. Ross, 1993, "Measurement of Microbial Biomass in Arctic Tundra Soils Using Fumigation-Extraction and Substrate-Induced Respiration Procedures, Soil Biology and Biochemistry 25:135-141. 
A-10 


\section{APPENDIX B:}

\section{SAMPLING OF SEDIMENTS FROM BOMB CRATERS AT J-FIELD}

\section{B.1 RATIONALE}

Reviews of historic aerial photographs and observations by field personnel have been used to locate hundreds of bomb craters at J-Field. Each crater represents a potential source of contamination. However, little or no information on contaminant characterization is available for these bomb craters. Ecologically, these craters may represent an important breeding habitat for amphibian populations at J-Field. Many of the amphibian species that occur at APG (ICF-Kaiser Engineers 1993) rely upon ephemeral fishless bodies of water for reproduction. If contamination is present in the craters, these potential breeding sites could pose a significant risk to the survival of amphibian populations at J-Field. This appendix describes the sampling design and methodology that will be used to characterize the nature and extent of contamination of the bomb craters.

\section{B.2 SAMPLING LOCATION}

Sediment samples will be collected from the bottom of approximately 30 bomb craters at J-Field and will be analyzed for TAL metals. Because the persistence of contaminants in bomb craters may differ depending upon ground conditions, a stratified random design will be used, with samples collected from craters occurring within wetland, grassland, and forested habitats. Crater sampling will occur largely in four areas with known concentrations of craters (based upon aerial photographs and on-ground observations), although craters from other areas of J-Field may also be sampled. The four principal sampling locations include (1) a grassland habitat in the western portion of the RPDG AOC; (2) Area D, a forested wetland area located to the northwest of the RPDG AOC; (3) a large marsh wetland area located southwest of the RPTS AOC; and (4) a wooded area located south of the TBP AOC (Figure B.1).

\section{B.3 OVERVIEW OF ANALYTICAL PROGRAM}

Although a variety of chemical compounds could be released during detonation of bombs, the present analysis will focus primarily on heavy metals. Metals are a common component associated with bombs and are likely to persist for long periods because of their relative immobility in the environment. In addition, some heavy metals, such as arsenic, lead, and zinc, may be present as inert fillers and/or constituents of different projectiles that were tested at J-Field. Although explosive compounds such as trinitrotoluene (TNT) and related degradation products could also be released by exploding ordnance, these compounds are less persistent and are more likely to have degraded. Analyses for explosives and their degradation products will be performed on sediment samples from approximately $25 \%$ of the craters. 


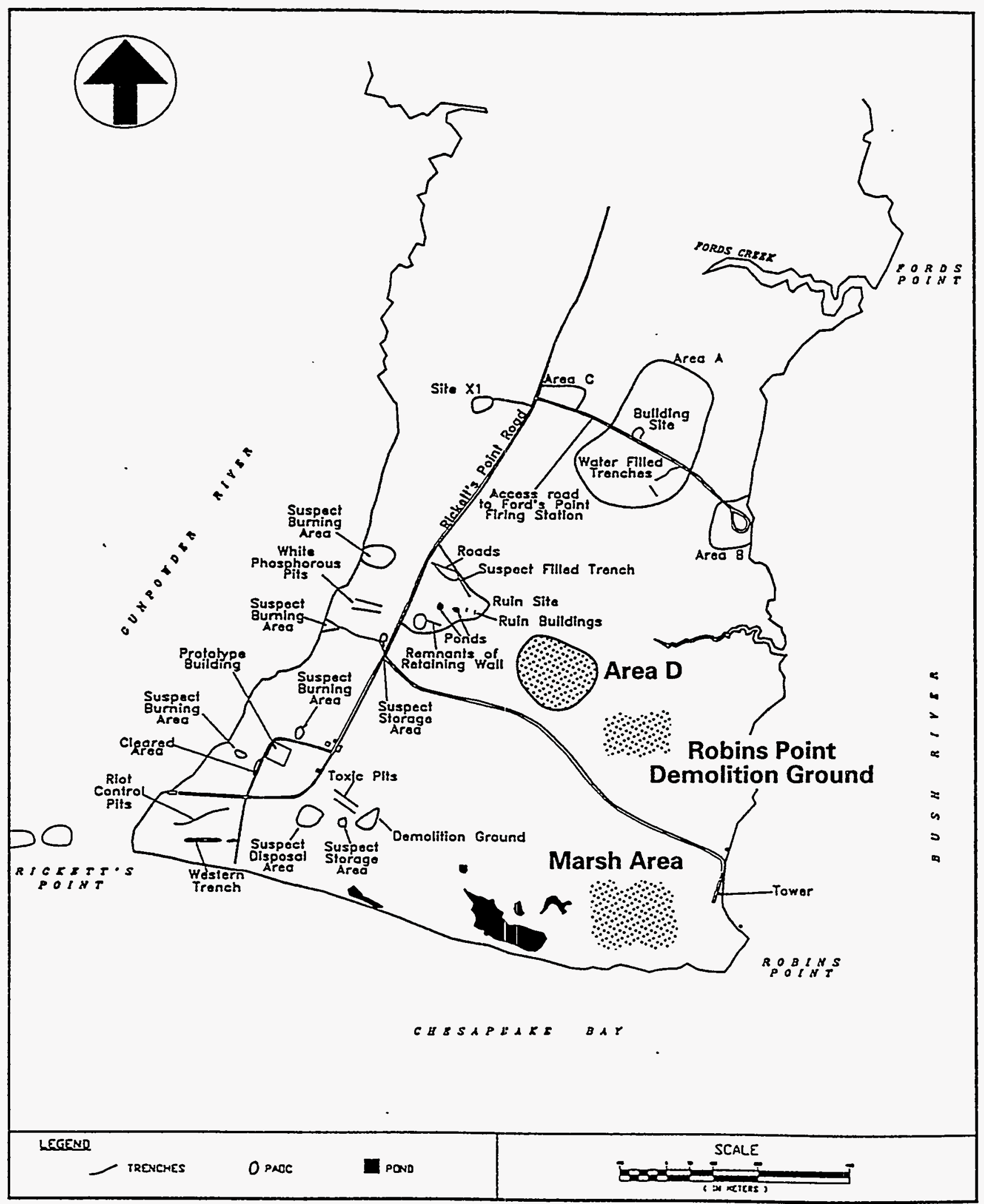

FIGURE B.1 Potential Sampling Areas Known to Contain Bomb Craters, Based upon Aerial Photographs and Field Observations 
X-ray fluorescence (XRF) will be used to perform field screening of the TAL metals concentrations. If good agreement exists between XRF and TAL metals analyses, XRF may be suitable for additional screening of crater sediments in the future. Detailed information on the analytical methodology for TAL metals analysis, explosives (including degradation products) analyses, and XRF screening is provided in the FSP.

\section{B.4 OVERVIEW OF THE SAMPLING METHODOLOGY}

Methods for the collection, handling, and preservation of the sediment samples will follow the standard operating procedures (SOPs) presented in U.S. Army Corps of Engineers (1993). These procedures include:

- SOP 001 - Sample Labels,

- SOP 002 - Chain-of-Custody Forms,

- SOP 003 - Field Logbook,

- SOP 004 - Sample Packing and Shipping,

- SOP 005 - Decontamination,

- SOP 021 - Sediment Sampling, and

- SOP 039 - Sample Preservation.

\section{B.5 QUALITY ASSURANCE/QUALITY CONTROL}

All sampling and analysis activities will follow the QA/QC procedures described in the Quality Assurance Project Plan (QAPjP) for J-Field. These procedures include the collection of duplicates for analytical samples and proper laboratory reporting requirements.

\section{B.6 SAFETY CONSIDERATIONS}

As required for all sediment sampling activities at J-Field, UXO surveys will be performed before sample collection. Because sediments will not be collected from depths greater than 6 in. or from unsurveyed pushout areas or disposal pits, CWA screening will not be required. Modified level $\mathrm{D}$ personal protective equipment, as described in the Health and Safety Plan for the J-Field RI, will be worn during all field activities, and personnel will follow pertinent safety protocols. 


\section{B.7 REFERENCES}

ICF-Kaiser Engineers, 1993, Risk and Biological Impact Assessment at U.S. Army Aberdeen Proving Ground, Maryland, Technical Plan Volume I, Abingdon, Md.

U.S. Army Corps of Engineers, 1993, Work Plan for CERCLA Remedial Investigation / Feasibility Study; Appendix J, Standard Operating Procedures, Directorate of Safety, Health, and Environment, U.S. Army Aberdeen Proving Ground, Md., in cooperation with Waterways Experiment Station, Vicksburg, Miss., Dec. 